\title{
WestVirginiaUniversity
}

THE RESEARCH REPOSITORY @ WVU

Graduate Theses, Dissertations, and Problem Reports

2009

\section{The riotous presence in American literature and culture}

\author{
Rebecca Skidmore Biggio \\ West Virginia University
}

Follow this and additional works at: https://researchrepository.wvu.edu/etd

\section{Recommended Citation}

Biggio, Rebecca Skidmore, "The riotous presence in American literature and culture" (2009). Graduate Theses, Dissertations, and Problem Reports. 4442.

https://researchrepository.wvu.edu/etd/4442

This Dissertation is protected by copyright and/or related rights. It has been brought to you by the The Research Repository @ WVU with permission from the rights-holder(s). You are free to use this Dissertation in any way that is permitted by the copyright and related rights legislation that applies to your use. For other uses you must obtain permission from the rights-holder(s) directly, unless additional rights are indicated by a Creative Commons license in the record and/ or on the work itself. This Dissertation has been accepted for inclusion in WVU Graduate Theses, Dissertations, and Problem Reports collection by an authorized administrator of The Research Repository @ WVU.

For more information, please contact researchrepository@mail.wvu.edu. 


\title{
The Riotous Presence in American Literature and Culture
}

\author{
Rebecca Skidmore Biggio
}

\author{
Dissertation submitted to the \\ Eberly College of Arts and Sciences \\ at West Virginia University \\ in partial fulfillment of the requirements \\ for the degree of \\ Doctor of Philosophy \\ in \\ English
}

John Ernest, Ph.D., Chair

Timothy Sweet, Ph.D.

Timothy Dow Adams, Ph.D.

Kathleen Ryan, Ph.D.

Kenneth Fones-Wolf, Ph.D.

Department of English
Morgantown, West Virginia 2009

Keywords: riot, lynching, violence, Reconstruction, race

Copyright 2009 Rebecca Skidmore Biggio 


\author{
ABSTRACT \\ The Riotous Presence in American Literature and Culture \\ Rebecca Skidmore Biggio
}

This project seeks a comprehensive understanding of riot as an operating principle in American history and culture - a principle variously revealed in, explored, or obscured by literature produced by popular and political novelists at the turn of the twentieth century. In defining riot as a presence, I identify as central to US history a haunting incoherence between fundamental cherished ideals of representative government and the use of violence or threats of violence to assert the privilege of one group through the subjugation of another.

Because representations influence the way we characterize historical events both prospectively and retrospectively, I conduct my investigation through the reading of iconic and influential literary texts. These literary texts, published broadly between 1880 and 1910, function as historical interventions rather than simple records of the American past. Charles W. Chesnutt's The Marrow of Tradition (1901), Albion W. Tourgée's $A$ Fool's Errand (1879), and Thomas Dixon, Jr.'s The Leopard's Spots (1902) are set in the present and shape the very cultural context on which they comment. Pauline Carrington Bouvé's Their Shadows Before (1899), Mary Johnston's Prisoners of Hope (1898), and Pauline E. Hopkins's Winona (1902) join issues of the past with issues of the present, establishing the continuity of historical events. Mark Twain's A Connecticut Yankee in King Arthur's Court (1889) and Sutton Griggs's Imperium in Imperio (1899) are prospective rather than retrospective, confirming the adaptability and embeddedness of riot, its many uses and manifestations in US culture, and its many disguises. Through the privileging of contexts beyond cause and effect, through the exploration of the normal functioning of the society in which these events can and do occur, literature offers a field for exploration of the social and cultural conditions necessary for the violence of riot to occur. 
Acknowledgements

John Ernest, my mentor and my friend.

Katy Ryan and Tim Sweet, my generous readers.

Tim Adams and Ken Fones-Wolf, my thoughtful committee.

My seminar group at the 2007 Dartmouth Futures of American Studies Institute, especially Donald Pease and Rebecca Adelman, for their early inspiration and ongoing support of this project.

My family and friends, especially John Biggio, Mike Skidmore, and Linda Atwell.

I also wish to express my appreciation for the generous financial support provided by the WVU Dissertation Fellowship, the Stephen Crocker Dissertation Fellowship, the Wilson Grant for Doctoral Research, the Jackson Family Doctoral Fellowship, the William E. Vehse Graduate Student Travel Award, the Eberly College Graduate Student Travel Award, the Eberly College Academic Affairs Doctoral Student Travel Award, and additional support provided through the Department of English at West Virginia University. 


\section{Table of Contents}

Introduction. Rethinking Riot 1

The Riotous Presence $\quad 4$

Reading and Writing Riot 16

Chapter 1. "De w'ite folks is riz": Riot, Revolution, and Race War in The Marrow of

Tradition $\quad 22$

Riot 26

Revolution $\quad 35$

Insurrection $\quad 44$

Race War $\quad 55$

Chapter 2. "From all such proffers of friendship": Dixon, Tourgée, "Brothers," and Liberals

Romancing Race and National Reunion $\quad 73$

Ideologies of White Fraternity and Regenerative Violence 85

Citizen Soldiers and the New Nation 99

Chapter 3. "Both Domestic and National": Three US Women's Narrative Interventions

in Masculine Histories of Collective Violence 117

"White Lamb" for the "Black Sheep": Pauline Bouvés Their Shadows Before 122

"With but a change of masters": Mary Johnston's Prisoners of Hope 135

"I will carry the war into Africa": Pauline Hopkins's Winona 153

A Violent Past in the Present 168

Chapter 4. "A Riot is At Bottom the Language of the Unheard": Riot and Rumor in the

Works of Sutton Griggs and Mark Twain

Two Americas 177

Ordering Disorder in Connecticut Yankee 183

The Circus of Riot $\quad 195$

Imperium in Imperio 200

Rumor, Race War, and The Specter of Cooperative Democracy 213

Coda. Meditations on An Activist Agenda 226

$\begin{array}{ll}\text { Bibliography } & 237\end{array}$

$\begin{array}{ll}\text { Curriculum Vitae } & 257\end{array}$ 


\section{Introduction. Rethinking Riot}

When I first began this project, the $100^{\text {th }}$ anniversary of the Atlanta race riot had recently passed. Commemorating the violence of 22-25 September 1906, with walking tours and historical research made public via the internet, The Coalition to Remember the 1906 Atlanta Race Riot has begun a project of remembrance and redefinition. The Coalition to Remember is one of many emerging organizations serving to honor the victims of late-nineteenth- and earlytwentieth-century race riots like those that occurred in Wilmington, North Carolina in 1898, in Chicago, Illinois in 1919, in Tulsa, Oklahoma in 1921, and in Rosewood, Florida in 1923. In 1993, for example, five university professors submitted “A Documented History of the Massacre Which Occurred at Rosewood, Florida, In January 1923” to Florida's Board of Regents. In 1997, the Oklahoma House of Representatives requested the formation of the Oklahoma Commission to Study the Tulsa Race Riot of 1921. In 2000, North Carolina's General Assembly founded the 1898 Wilmington Race Riot Commission "to develop a historical record of the event and to assess the economic impact of the riot on African Americans locally and across the region and state." In addition to promoting awareness, some of these groups, like the Tulsa and Rosewood organizations, have sought reparations for the victims' families. Each of these public initiatives represents both a commendable recuperative effort and an important trend toward a collective attempt to uncover the lost truths behind these painful reminders of domestic terrorism occurring Within Our Gates, to borrow the title phrase from Oscar Micheaux's 1920 cinematic response to the riots in Chicago.

In part colluding with and in part diverging from the work of these vital programs, I argue against the collective tendencies of the public to see these events as contradictions, as exceptional, irrational occurrences outside of the normal functioning of American history and 
culture. Instead, I argue that these race riots are fundamentally American, that they are an ongoing and central part of American social process. Isolating individual riots as spontaneous and aberrant events, as breaks in the cultural process rather than as moments of revelation, is dangerous, because this type of thinking alienates the symptoms from the disease. Recognition of the individual events and of the victims is essential, yet it is also critical to look beyond these seemingly discrete tragedies to the larger structural instabilities that they reveal. The Riotous Presence in American Literature and Culture looks for patterns, for repetition, for similarities, so as to understand these events in national, cultural, and historical contexts. In order to be truly productive, recognition must also be preventative and transformative. We must place these events in the context of a larger culture of violence, of revolution and resistance, and of the underlying ideologies that guide us in our understanding of violence as aggressive or defensive, as aberrant or normative.

There remains significant disagreement about how to identify these isolated events, these symptoms of greater cultural maladies. In their introduction to Democracy Betrayed: The Wilmington Race Riot of 1898 and Its Legacy (1998), Timothy B. Tyson and David S. Cecelski discuss at length the available "descriptive terms," any one of which might be a more procedurally accurate or desirable designation for what happened in Wilmington: “'coup d'état,' 'massacre,' 'revolt,' 'pogrom,' 'revolution.' Each conveys a part of the truth, yet none captures the full scope of these events." Tyson and Cecelski go on to explain their use of "race riot" in their title in terms of paying "homage to conventional usage" and in the interest of ensuring "that we would be understood" (6). While I find this quest for a satisfying descriptor a useful one, this sort of redefinition is not exactly what I am after. Rather, it seems necessary to me to approach 
the same set of questions from a slightly different angle, to ask, instead: What does it mean to call something a race riot?

My project looks less to the "history of what happened" than to the discourses surrounding eruptions of violence like the Wilmington race riot (6). Cecelski and Tyson and their impressive cohort of interdisciplinary contributors, and others involved in similar recuperative projects focusing on other race riots, have done much to reconstruct a faulty historical and interpretive record, leaving me free to build upon their pathbreaking work. To these ends, I explore the ways in which the determination "race riot" prospectively characterizes an event. When we read of a race riot in the newspaper for the first time, when the event is new, when we, as a public, are unfamiliar with the details of what happened, when the context, perhaps, remains in question, we formulate a certain kind of response based on the terminology. What does "race riot" say about an unfamiliar event? Whose involvement does it imply? More specifically, who do we assume has rioted? Who are the victims and the perpetrators? What started it? How did it end? What sorts of contexts and histories and agendas are implied and by whom? How is it disseminated - in the press, in the courts, in the streets? Conversely, when we retrospectively identify an event as a race riot, we give it a certain kind of place in history. We suggest a certain kind of context, of conflict, of outcome, of illegitimacy. We presuppose for future generations that this event has a certain value, a certain kind of meaning. My interest, then, is in the causes and consequences surrounding the application of this terminology. Most importantly, perhaps, I am interested not in options for renaming but in options for re-evaluating riot, not as a single event but as a pattern, as a phenomenon, as a presence. 


\section{The Riotous Presence}

Central to my study, then, is the difficult process of defining riot, which, in recent scholarship, has often come down to a careful rewording of dictionary definitions. For instance, Paul A. Gilje begins his historical study, Rioting In America (1996), with this standard definition of riot as "a tumultuous disturbance of the public peace by three or more persons assembled together and acting with a common intent" (4). Once refined for the purposes of his discussion, riot becomes "any group of twelve or more people attempting to assert their will immediately through the use of force outside the normal bounds of law" (6). As Gilje's increasingly directive rhetoric suggests, even the most inclusive definitions succumb to the temptation to see riot both as isolated in time and space and as an exceptional occurrence, outside of and contradictory to the foundations of American Constitutional principles. Because we are bound by these ideas about riot, we find ourselves constantly rephrasing, focusing on secondary factors-like whether three or twelve people constitute a riot and whether the requisite action is best considered tumultuous or forceful. In his introduction to American Mobbing, 1828-1861: Toward Civil War (1998), David Grimsted similarly outlines the meaning of riot according to the terms of his study, although Grimsted is careful to add that rioters act "ostensibly to correct problems or injustices within their society without challenging its basic structures" (xii, emphasis mine). In this way Grimsted differentiates between riot and some of the other terminology in consideration. Revolution or coup d'état, for example, do presuppose a fundamental change to the social order that riot and its implied spontaneity do not. In other words, riots are an operating principle within the social order.

Even the most inclusive traditional definitions of riot are faulty, because they are dependent upon the idea that there is some fundamental cultural order to be disrupted rather than 
an ongoing state of structured disorder. Looking back to the colonial and early national periods in The Dominion of Voice: Riot, Reason, and Romance in Antebellum Politics (1999), Kimberly K. Smith establishes a theory of mob action as central to the foundational principles of the United States, both pre- and post-Revolution, to "the question of how the people should participate in politics" (vii). In her consideration of a developing national political culture, Smith offers an extended discussion of "the people" as a problematic concept in a post-Revolution climate of government-by-the-people, therein calling attention to the fraught transition of riotousness from colonial rebellion to "the establishment of democracy." Pre-Revolution, rioting was understood as "a form of popular politics" indicative of a "breakdown in deference relations." Post-Revolution, however, "riots tended to call into question the ability of the people to rule themselves." No longer representative of "the dangers of government tyranny," rioting in "the context of a democratic regime" illuminated the "dangers of democratic politics—namely, its tendency to degenerate into mob rule" (39). Here Smith's conclusions suggest that the people's tendency to engage in mob violence did not undergo a significant change after the Revolution but that the way Americans perceived mob violence in terms of political participation did indeed shift substantially. The people who made up the mob, no longer deferential subjects of a separate tyrannical government, were now the sovereign representatives of national authority. This change prompted a reconsideration of the way Americans defined the place of mob violence in their social order.

Within shifting definitions of the place of violence in political participation emerged a raced, classed, and gendered understanding of mob violence as legitimate reason for exclusion from the political realm. Tracing the evolution of a preference for rational debate as the ideal form of democratic participation in the antebellum period, Smith notes the corresponding 
distinctions "between force and argument, mirroring the opposition between riots and legitimate political activity" (70). By the antebellum period, riots had come to be seen as "apolitical disturbances." "Seeking to legitimate democratic government by disassociating it from mob rule" after the Revolution, Smith claims, many political elites "characterized riots not as a form of political action but as a negative model of politics - an example of what democratic politics is not" (12). In this way, a purportedly calm and rational political experience, represented by articulate debate and characterized by restraint, came to represent fitness for citizenship and legitimate democratic participation, to the exclusion, or disqualification, of others who engaged in more disorderly or emotional expressions of citizenship. "Significantly," Smith writes, "this interpretation shifted focus from the rebellious character of rioting to its passionate, violent aspect, thus giving prominence to the interpretive categories of violence and argument (corresponding to the underlying categories of passion and reason) instead of obedience and rebellion" (12-13). Consequently, presupposing proper political participation in direct opposition to violent rebellion nullifies the potential for understanding violent resistance as legitimate. Deference, then, is built into the system in ways it was not before.

In fact, the potential for violent disorder defines the very terms of the social order, and the response of the body politic to try to reshape that disorder into rational hegemony is an exercise in obfuscation rather than a genuine transformation. Literary critic Ed White probes this concept in The Backcountry and the City: Colonization and Conflict in Early America (2005) via Jean-Paul Sartre's philosophy of group fusion and White's own analysis of the "rural-urban 'class' conflicts of early America" (77). "The group-to-be," White argues, "had to perceive both its necessity (its danger) and its possibility (its defense) in the material environment. But material possibility, in this brute form, is not the crux of Sartre's analysis." White's point is that "the 
cultural tools" must be present for group fusion: "the perception of other groups and group members, a sense of serial impossibility and group possibilities, and a self-understanding of past, present, and future moments critical to the group" (77). Rather than a matter of biological necessity, the fused group is the result of the combination of material need and the cultural understanding of that need as being somehow inhibited by members of other groups. Group fusion, then, at its most basic, is a survival technique wherein groups define themselves in relation to many other groups who pose a potential threat to the collective, a threat that cannot be adequately defended by the individual, or serial, components of the group. It follows that the fused group depends upon a culturally grounded preparation for potentially violent defense against other groups. If threats provide the group with the terms of its cultural closure and coherence, as White suggests, then the cultural means for violent repression of threats is central to group fusion. Group fusion and the potential for violence therein are fundamental parts of the social order that cannot be undone by the political rhetoric of reason or the articulation of a collective preference for rational debate.

To consider the formation of the fledgling nation in terms of group fusion and the collective response to the threat/disorder of tyranny and invasion is also to note that the group contains the elements of the threat/disorder. Grimsted parses this paradox when he observes that "riots were neither rare nor commonplace in antebellum society but a piece of the ongoing process of democratic accommodation, compromise, and uncompromisable tension between groups with different interests" (viii). Rather than a single, conceptually coherent social orderthe nation-Grimsted identifies regional, political and racial conflicts played out through violent repression. Focusing on slavery, which he calls "the nation's deepest and most divisive anomaly," Grimsted traces the patterns of anti-abolition mobs, fugitive slave riots, extralegal 
Southern mobs, insurrection scare panics, and election riots, among others, throughout the antebellum period. As Southern anti-abolition mobs, for example, suggest, localized expressions of mob violence were often aligned with local or regional if not national authority and therefore inspired the sort of deference that rational debate was to have replaced. Grimsted contends that "mobs against 'abolitionists' also were too pragmatically effective to allow doubting. These riots encouraged silence, caution, and fear about broaching anything but unqualified praise of slavery" (123). In this way mob violence asserted itself in place of rational or juridical debate. As Grimsted argues, "mob activity, like personal violence was less an attack on legality than an alternating system to which Southerners could resort when it offered securer promise of gaining 'justice,' revenge, power, or property. It was often justified in terms of weaknesses in the formal legal system in ways that were dubious but telling about its alternative status"(110). In other words, mob action regularly supplanted national authority, violently replacing it with local authority, and highlighting the dissension among a multiple and fragmented body politic. The issues of slavery and abolition were fundamental faultlines along which various groups were divided, and conflicts surrounding these issues placed violent control of a threatening force at the center of group identities.

Indeed, the first sixty years or so of the nation's political order resulted in Civil War. Grimsted traces the people's penchant for mob violence to the immediate prewar period, when "Kansas brought into conflict the sectional patterns of violence that had been developing for two decades and focused them on the slave issue" (247). With the Kansas-Nebraska Act of 1854, Democratic Senator Stephen Douglas of Illinois sought to soothe the sectional tensions exacerbated by the spread of slavery in the South and in the territories and by increased resistance in the North by declaring that Kansas' status as a slave or free state would be decided 
by popular sovereignty. The resulting intermittent violence of $1855-1858$ elucidates the literal danger of popular sovereignty to devolve into mob violence and further into Civil War. "The importance of Kansas," Grimsted offers, "lay less in the bloodshed than in the political reverberations of the conflict, as the country became divided on a sectional basis between controlling parties dedicated centrally to slavery's constriction and to slavery's expansion" (247). Sectional divisions were further solidified by proslavery violence in Kansas. For many opposing settlers, "their antislavery was less a moral commitment than what they saw as the policy that best served their just interest and influence. And the threats, bombast, and violence of proslavery groups offered blaring testimony for abolition's most effective theme from 1835 on: slave owners were as determined to master and debase whites who disputed their dominion as they did the blacks they owned" (249). Bleeding Kansas was not merely a fight for a territory but the consolidation of otherwise disparate groups in opposition to or defense of the immediate and compelling social threat of slavery, which gained force through the visible ruptures of riot in the early national and antebellum periods. In short, the dynamics of American politics and American political theory made repression an operative principle and civil war almost inevitable, given the regional and political tensions defined by the system of slavery.

These internal tensions did not develop as a result of the Revolution but rather were built into the revolutionary project. In defining riot as a presence, I am building on Andy Doolen's definition of a "fugitive imperial state" which "also haunts, also embodies slavery's tragic past, but it still appears invisible to historical analysis and retains the source of its power" (xxi). Early American republican ideology is predicated on the positive denial of imperial practices. "These practices," Doolen argues, 
occur when the state converts skin and blood into the legal justifications for slavery, when it polices racial hierarchies with a special class of penal laws, when it reinforces ideals of white racial purity through official rituals of execution and banishment, and finally when the state invents official narratives of insurrection and invasion as a strategy for reinforcing political authority. These racial fictions - taking the form of official discourse of law, policy, proclamation, and public ritual—constitute the logic of U.S. imperialism in the late colonial and early national periods, transforming the terror of white supremacy into a rational and permanent presence. (xxi)

Here Doolen establishes that imperialism, terror, and racial violence do not simply posit slavery as "America's dirty secret" but are rather fundamental to the maintenance of American republican ideals (xvi). "The critical paradigm of American exceptionalism, which reaffirms the fundamental ideals of the age of revolution" Doolen notes "has long denied the existence of imperial authority in early America. This critical perspective proliferates the myth that the American Revolution extirpated the force and logic of empire with the irresistible and heroic dreams of egalitarianism and freedom." Instead, Doolen argues, "the republican rhetoric of liberty and equality for all not only obscured but, more insidiously, legitimized the operations of imperialism" (xiii).

This rhetoric also posits race and repression as agents of the political tensions built into the socio-economic and political system. As Matthew Frye Jacobson points out in Whiteness of a Different Color: European Immigrants and the Alchemy of Race (1998), "in practice the idea of citizenship had become thoroughly intertwined with the idea of 'whiteness' (and maleness) because what a citizen really was, at bottom, was someone who could help put down a slave 
rebellion or participate in Indian wars" (25). White male citizenship was therefore visibly defined in opposition to the riotous or rebellious violence of non-citizen, non-white Others. Just as citizenship has long been defined in terms of white Americans' perceived capacity for rational self-government, "Americans' handling of racial questions had profound implications for the political experiment for which God had set aside the continent in the first place.” As Jacobson argues, "the matter at hand was no less than the fate of 'self-government' as a viable political principle" (71-72). So, the fate of the American political experiment was dependent on the exclusion of the "racially marked Others" whose very presence at the same time "reified and further united the 'white persons' of the 1790 naturalization law. In as much as no one was suggesting that citizenship actually be revoked from those who had already entered under the terms of 1790, any discussion of the total exclusion of certain groups - whether Africans, Asians, or both - tended tacitly to endorse the unifying logic of a single European race whose credentials for self-government were above reproach" (74). In this way, the mob action of whites-in service of putting down revolt or defending national borders - comes to be defined and understood as normative, legitimate, and self-defensive in contrast to the riotous, disorderly, passion-driven mob action of racial Others.

In other words, the structural principle of repression is manifest in the black bodies that trouble the body politic. Black bodies are the visible reminders of slavery's presence within the purportedly exceptional republic, the whisperers of the open secret of empire. "From the standpoint of human subjects," David Theo Goldberg observes, "nothing is more 'natural' to think and speak about than the body. It is directly experienced, its deficiencies immediately felt; and it is usually taken as the receptacle or 'container' of pleasures and pains, desires and needs. The bodies of others are unproblematically observable, confronted, and engaged" (54). 
Observable black bodies simultaneously elicit the violent control of what was perceived to be a potentially violent presence - the enslaved, or African disorder generally. The perceived threat contained within black bodies is therefore central to group fusion in the formation of white national identity. As Goldberg argues, "the body comes to stand for the body politic, to symbolize society, to incorporate a vision of power. Porous and permeable though the boundaried 'skin' of the body politic may in fact be, it is constituted always in terms of the bordered criteria of inclusion and exclusion, identities and separateness, (potential) members and inevitable nonmembers" (54). As a political system founded upon "the potential for "invasion or insurrection' and its attendant 'necessities,'” American republican ideology virtually mandates that racial exclusions be maintained through violence (Jacobson 25). These fundamental, foundational, structural instabilities make racial violence an almost inevitable presence in American life.

Following Goldberg and Jacobson, then, I suggest that not only is race as a concept developed in conjunction with political ideologies about mob action and representative citizenship but that mob action is defined as legitimate or illegitimate (reason or passion) in conjunction with shifting and transforming ideas about race. Indeed, nationalism is less a narrative than a "field of racialized discourse" including rules of discursive control (Goldberg 42). "As the formative rules are historically specific and thus subject to change," Goldberg suggests, "so, too, is the discursive object in question. Racism is not a singular transhistorical expression but transforms in relation to significant changes in the field of discourse" (42). The interconnected discourses of race and riot become inextricable as each defines the other. Riot comes to be understood as riot, rather than as defensive or legitimate political action, based on the racial classifications and relative social standings of the groups involved, and any action on 
the part of non-white raced groups comes to be understood in terms of riot. Race intervenes to redefine riot not in the pre-Revolutionary terms of a breakdown in deference relations, as English colonials had once understood their own rebellious mob action, and not in the post-

Revolutionary white ideal of unified defense against external threats to the democratic ideal. Instead, race codes riot as tyranny itself, as disorder fundamentally opposed to the orderly exercise of democratic citizenship or responsibility. According to Goldberg, "race is a discursive object of racialized discourse that differs from racism. Race, nevertheless, creates the conceptual conditions of possibility, in some conjunctural conditions, for racist expression to be formulated." Therefore, "the law, moral discourse, and the social sciences can thus silently incorporate racialized language ... while claiming to be antiracist" (42). Via this racialized discourse, American "democratic" politics simultaneously denies racial Others citizenship as well as any recourse to resist their own oppression.

Similarly, I carry Doolen's logic into postbellum America when I argue that riot and racial violence are the physical manifestations of official discourses of exclusion and justification, which have changed in form but not in function since the colonial period. With the abolition of slavery and the passage of the Fourteenth and Fifteenth amendments in 1868 and 1870 respectively, legal and social conceptions of citizenship and "the people" became exponentially more complicated, as did the dynamics of race and riot. African American men, who had been officially excluded from the polity by the institution of chattel slavery, were suddenly thrust into the political sphere, a polity founded, in the early national period, explicitly on their exclusion. For this reason, my study focuses on the late nineteenth and early twentieth centuries, and specifically on the post-Reconstruction period, which includes the 1890s, a decade commonly marked as the deplorable "height" of lynching. Lynching and race riots in the 
postbellum period, like slavery in antebellum America, were not the nation's dirty secrets. Rather, in a period of American history when dominant contemporary narratives indicated that social equality had been achieved, that the United States had again reinvented itself, rewritten its rules, and recovered its republican ideals from the jaws of slavery, lynching and race riots are reconstitutions of the principles of slavery, insidiously legitimated by the rhetoric of republican renewal, national reunion, and Emancipation.

The riotous presence, then, is created and nurtured by this haunting incoherence within the US between fundamental cherished ideals of representative government or the rule of law and the use of violence or threats of violence to assert the sovereignty of one group through the subjugation of another. Doolen recognizes this paradox when he identifies the production of white racial solidarity, the maintenance of a master class, and terror as "embedded in colonial and national narratives" (xx). This disparity between an ideal American republic and the structural, functional white supremacy by which it is maintained is entrenched in racialized nationalist discourse and is the determining factor in the maintenance of the cultural order. Like Doolen's fugitive empire, which is haunting because of its quiet insidiousness, the riotous presence is also ghostlike, so much a part of the structure of culture and the everyday lives of Americans that its paradox is hard to locate and even more difficult to explain. Often those who would unmask it are also the Others whose voice it denies. The riotous presence is the function of an ongoing circular process, of a troubled revolution continuously maintained and reenacted via racial violence and forceful exclusion. Doolen writes: "In a revolutionary society of rebirth, where colonial subjects became citizens and colonies became states, slaves were reborn as slaves (xix). Similarly, in a cultural order fundamentally disrupted by fraternal disunion and civil war, where national union is both achieved and strengthened via the reconsolidation of masculine 
white supremacy, de jure slaves are reborn as de facto slaves, and the racial hierarchy remains intact. In fact, the racial hierarchy is reasserted in the interest of national reunion, whereupon any continued agitation on the part or behalf of ex-slaves and African Americans threatens not only white supremacy but the renewed democracy enabled by its conceptual overthrow.

When I say that I am working to establish that lynching, race, riots, and slave insurrections are not separate and distinct but interconnected manifestations of an ongoing riotous presence in American history and culture, I am not assigning value to or eliding the differences between an act like lynching, which serves to brutally reinforce a culture of control, and a slave insurrection, which, also brutally, works to challenge that same culture of control from within. What I want to do, in identifying a riotous presence, is to link these purportedly discrete eruptions of violence to the dominant ideology that makes them both possible and, arguably, necessary. This is a culture that cultivates an ideology of manly independence in white men at the same time as it denies other men (and women) the right to assert their own independence on the same terms. It is a culture that suggests that defensive violence, on behalf of one's home and one's country, is both a right and a responsibility of citizenship at the same time that it disavows any resistance to its own brutal tyranny. It is an unstable culture that, in making oppression and exclusion a fundamental if unacknowledged part of its democratic discourse of liberty and freedom for all, virtually guarantees that violence will be a daily and nearly unavoidable occurrence. These violent events, these eruptions of underlying instabilities, are not separated by time or space or transitory social systems. They will repeat and reoccur, in different contexts, as long as the social order depends upon the violent management of its structural and ideological instabilities. 


\section{Reading and Writing Riot}

The Riotous Presence in American Literature and Culture combines political theory, philosophy, critical race theory, and history with literary scholarship in a multidisciplinary approach to identifying and laying bare the contesting and incompatible social logics of ideal American constitutional democracy and functional white supremacy. Literary, historical, and political science scholars have identified mob action as central to the foundational principles of the United States, both pre- and post-Revolution. However, much of this discussion is devoted to antebellum America and to limited conceptions of race in the context of anti-slavery. The Civil War dramatically changed the racial landscape of the United States, as well as legal and cultural definitions of "the people." Therefore a reconsideration of these theories in the context of postbellum American is both warranted and necessary. Recent histories of postbellum racial violence, like Philip Dray's At the Hands of Persons Unknown: The Lynching of Black America (2002) and Leon F. Litwack's Trouble In Mind: Black Southerners in the Age of Jim Crow (1998) focus primarily on the frequency and ritual of lynching. The implication, in both literary and historical scholarship, is that lynching and race riots are related but somehow distinct events. Now-classic studies like Trudier Harris’ Exorcising Blackness: Historical and Literary Lynching and Burning Rituals (1984) as well as recent analyses, like Sandra Gunning's Race, Rape, and Lynching: The Red Record of American Literature, 1890-1912 (1996), also examine mob violence almost exclusively in the context of lynching. With this important context in mind, my project seeks to focus on and to reconceptualize riot as a category for historical analysis, not limited to but focusing on the postbellum period.

Riot, then, is useful because it renders the tacit explicit. In other words, riot can function as a written text, as a potentially transformative moment during which cultural instabilities are 
pushed to their breaking point. Accordingly, I conduct this investigation through the reading of iconic and influential literary texts, which serve as my entry into the fields of racialized discourse and the rules of discursive control on which the riotous presence thrives. Because representations influence the ways we characterize historical events both prospectively and retrospectively, these literary texts, published roughly between 1880 and 1910, function as interventions in rather than simple records of United States history. I look to literature of the post-Reconstruction period for a more comprehensive understanding of riot, because literature attempts to move beyond the simple reporting of an event and toward representation of a complex cultural dynamic. Through the representation of events beyond cause and effect, through the exploration of the normal functioning of the society in which these events can and do occur, literature exposes things beyond even the author's intentions. This is not to say that all literature either supports or resists a dominant national narrative, or that I have chosen literature for this study specifically because it does either. Literary representations like those I examine here offer a field for exploration of the social and cultural conditions necessary for the violence of riot to occur and reveal how individual and cultural perceptions are shaped, how riot is understood. The literary representations included in this study expose the violence of riot, broadly understood, as the tangible manifestation of an operating principle in American history and culture rather than an isolated eruption with a beginning and an end. They go beyond placing the event in context to privileging the context over the event.

Literature experiments with and explores different modes of producing a discourse of the events. Accordingly, the novels of chapter 1 and chapter 2 are set in the present and shape the very cultural context on which they comment. Chapter 1, “'De w'ite folks is riz': Riot, Revolution, and Race War in The Marrow of Tradition," offers a case study via Charles W. 
Chesnutt's The Marrow of Tradition (1901), in which Chesnutt establishes that culture is based on tenuous social fictions which are maintained and strengthened in the press, in the courts, and in private homes. I follow Chesnutt's lead in sorting through the application of different terms to describe the 1898 Wilmington, North Carolina, race riot, and to differentiate the legitimate violence of one group from the illegitimate violence of the other. These normative discourses by which culture is both regulated and managed are utterly fragile. Riot, in Chesnutt's novel, is the natural result of the normal functioning of such a society fractured by the constructs of social, familial, and political legitimacy based on race. In The Marrow of Tradition, the onset of riot signals the inevitable rupture of these social fictions, and with that rupture comes the opportunity to reenvision society by more coherent principles.

Literature investigates the driving impulse behind the need to keep talking about it - the trauma of the event and its aftermath, as well as the cultural trauma it obscures. Where Chesnutt attempts to extend the boundaries of riot, the novels of chapter 2 attempt to contain it, to preserve a cultural order in which riot operates within the bounds of law. In "“From all such proffers of friendship': Dixon, Tourgée, Brothers and Liberals," I discuss fundamental similarities between the virulent racism of Thomas Dixon, Jr.'s The Leopard's Spots: A Romance of the White Man's Burden, 1865-1900 (1902) and the "radical" liberalism of Albion W. Tourgée's A Fool's Errand: By One of the Fools (1879) within the specific context of post-Reconstruction-era white supremacist violence. Despite his reputation for color-blind politics, Tourgée's authorial inability to imagine African American lives as authoritative or independent rather than socially and politically dependent helped to create and sustain a cultural climate in which Dixon's vicious tale of black degeneracy and white triumph could enjoy such an immense popular success. These two politically oppositional novels represent two warring factions of a white masculine cultural 
discourse which sacrifices African American social and civil rights at the alter of national white reconciliation - the reconstitution of an ideal and imagined white fraternity.

The intersecting discourses of race and riot — and of class and gender — are variously, potentially, and actually transformed in literature, as the novels of chapter 3 illustrate. Pauline Carrington Bouvé's Their Shadows Before: A Story of the Southampton Insurrection (1899), Mary Johnston's Prisoners of Hope: A Tale of Colonial Virginia (1898), and Pauline Elizabeth Hopkins's Winona: A Tale of Negro Life in the South and Southwest (1902) are collected here because the authors' common experiences as women in a decidedly masculine culture significantly shaped their narrative approaches to oppressive violence, organized resistance, and purportedly collective memory of the same. Via retrospective interpretations of more distant historical events, these authors take on issues of white supremacist violence and of representation within the mediated feminine genres of adolescent fiction, historical romance, and maternal melodrama, emphasizing the ways in which cultural violence is represented and discussed primarily in terms of the male participants and the meanings assigned by a masculine culture. Moreover, each of these novelistic negotiations of racial, sexual, and class-based cultural politics works to effect an outsider consciousness by which the authors present themselves as uniquely capable of recognizing structural violence, yet they ultimately reveal their own cultural limitations.

The fantastic novels of chapter 4, Mark Twain's A Connecticut Yankee in King Arthur's Court (1889) and Sutton E. Griggs's Imperium in Imperio (1899), are prospective rather than retrospective, therein raising this pertinent question: Does violence create literature, and, if so, how? In building to Twain and Griggs I also build to uncertain conclusions. Both understood the structural instabilities, both wrote novels that draw us into the violent manifestations or effects of 
those instabilities, but both also struggle for a narrative capable of accounting for American history and culture. They represent the riotous presence in action, as it develops from an inherently fraught conception of republican ideology and through its various revelatory moments of crisis, as the threat of disorder consistently self-replicates with each attempt to achieve or maintain a stable order within an unstable cultural framework. Twain and Griggs are, however, less interested in providing an alternative to the prevailing cultural disorder than they are in suggesting the dangers inherent in replicating narratives of nationalist exceptionalism. These dangers, they reveal, are most visible at the underside of standard narratives of progress, in the plausibility of underlying rumors of violent protest and in the riots they portend. Also implicit in these novels is a demand for greater accountability, for greater responsibility, on the part of cultural and political leaders and among the people who make up the greater body politic, yet the means to achieve this remains undetermined.

The Riotous Presence in American Literature and Culture is, then, a study of both the power and the limitations of fiction to represent this world and to imagine a better. Whether or not they are aware of their own cultural boundaries or capable of transcending the various cultural influences with which they grapple, these novelists do draw us into an understanding of the structural instabilities of American culture and provide us with strategies for addressing the present, rethinking the past, and redirecting the course of our collective lives. They also illuminate for us the many problems inherent in mounting individual resistance efforts from within such an incongruent social system in fact predicated on the structural nullification of real resistance to oppression, violent or otherwise. In declaring itself the exception to the oppressive nation-state, the American political machine has rendered the exception the rule, a conceptual constraint within which these authors visibly labor. Significantly, the resulting novels are not 
blatant and predictable stories of injustice but rather representations that elicit the complex exchanges of participants, victims, and observers within the complicated history of our legal system. 


\section{Chapter 1. "De w'ite folks is riz": Riot, Revolution, and Race War in The Marrow of \\ Tradition}

If the mainspring of popular government in peacetime is virtue, the mainspring of popular government in revolution is virtue and terror both: virtue, without which terror is disastrous; terror, without which virtue is powerless.

-Robespierre, Virtue and Terror (115)

The moment you pronounce, in one of your decrees, the word slave, you will be pronouncing your own dishonour and the overthrow of your constitution.

-Robespierre, Virtue and Terror (20)

Nearly a century after its original publication, The Marrow of Tradition (1901), Charles W. Chesnutt's "magnum opus," would finally receive the critical status its author so desired (Andrews 175). Set against the backdrop of the 1898 Wilmington, North Carolina, race riot, The Marrow of Tradition goes beyond reporting a "counterhistory that resists dominant history and rewrites it in resolutely local terms," to reflecting the mechanisms that allowed for the privileging of one historical narrative over another (Wilson 112). That is, through the juxtaposition of multiple perspectives and experiences, Chesnutt reveals how the actions of the white supremacists in the context of the Wilmington riot and beyond came to be historically understood as legitimate in opposition to the "illegitimate" actions of Wilmington's black citizens. The Marrow of Tradition reveals the mechanisms of a white supremacist culture that are central to the creation of these fictions of legitimacy in terms of genealogy, personal relationships, political activism, and, ultimately, violence. The novel is as much a study of white methods, a history of subordination, and a rhetoric of legitimate revolution as it is a study of the specifics of 10 November 1898. Mirroring the practices of an inherently white supremacist culture, Chesnutt exposes the ways in which white supremacy functions as a self-regenerating 
sociopolitical order through the recognition of some violence as legitimate while discounting other violence as spontaneous, disordered, and illegitimate.

In the years before the Wilmington massacre, the Port City was a place of opportunity for blacks, many of whom held high-paying positions of relative power, both within the city's business class and as members of local government. By the time of the riot, blacks outnumbered whites in Wilmington, where they served on the city's board of aldermen, as police officers, as justice of the peace, and as coroner; they were restaurant owners, barbers, tailors, butchers, grocers, mechanics, brickmasons, watchmakers, and real estate agents, and many kept offices downtown rather than in segregated black neighborhoods (Prather, "We Have Taken a City" 1617). After the March 1897 municipal elections in Wilmington, when Fusionist efforts at the state level to overhaul North Carolina's election practices had seen results locally, the balance of power in city government shifted away from the Democrats (20-21). This rise of Fusion politics throughout the Black Belt, created by the success of the Republican-Populist union in 1894, inspired a statewide white supremacy campaign in 1898, spearheaded by prominent white Democrats and carried out in the white press. In August 1898, an anti-lynching editorial written and published by black Wilmington newspaperman Alexander Manly, in which he castigated white men for the rape of black women and suggested that sex between white women and black men was just as often consensual, became a platform for the white supremacy leaders, who vocally promoted and nurtured myths of black brutality and fears of "Negro Domination" among the state's white citizens. ${ }^{1}$

By the time of the November election, tensions were high and citizens on both sides of the color line were attempting to arm themselves. On election day, 8 November, a combination of intimidation and fraud resulted in Democratic victory. On 9 November, Wilmington's white 
supremacist contingency, led by a group of influential Democrats dubbed the "Secret Nine" and by visible figurehead Alfred M. Waddell, gathered members of Wilmington's black leadership to issue an ultimatum stipulating that they agree to the demands outlined in the newly penned "White Declaration of Independence," which included the resignations of the standing Fusionist government and the forceful expulsion of Manly. ${ }^{2}$ Wilmington's black leadership drafted their response, but their messenger did not succeed in delivering it to Waddell as instructed. ${ }^{3}$ The anticipated violence did not occur until 10 November, two days after the election. Armed whites gathered in the morning at the Wilmington Light Infantry, prepared to enforce the objectives outlined in their new "constitution." The violence began with the destruction of Manly's press in the morning and spread into the streets where the shooting started. ${ }^{4}$ Much of the firefight would take place in Brooklyn, one of Wilmington's predominantly black neighborhoods, between heavily-armed whites and poorly-armed blacks, while incidents continued throughout the city, including the stopping and searching of blacks. The white supremacist involvement already included both volunteer citizens and organized militia groups the Red Shirts and the Rough Riders when martial law was declared that afternoon to "preserve peace" (WRRC 433-434). The violence in the streets persisted, with the military ordered to "shoot to kill," while the mayor, the board of alderman, and the police force were compelled to resign and were replaced by Democrats on Waddell's orders (WRRC 434; Prather 36-37). By dusk the shooting had abated, but it continued intermittently into the night in Brooklyn. The mob had claimed an unknown number of black victims, with later reports ranging from nine to more than 100 (Prather 35). ${ }^{5}$ Prominent Republicans, both black and white, and middle class blacks were forcibly exiled from the city. Other frightened blacks, including women and children, fled the city in droves to hide in nearby woods and swamps for several days. Martial law remained in 
effect the following day, while Waddell, newly-"elected" mayor of Wilmington by the newlyplaced Democratic board of aldermen, reorganized his command (WRRC 435-436; Prather 37).

With few exceptions, the contemporary mainstream white press, both locally and nationally, white political and intellectual leaders, and white clergy not only accepted but championed the white supremacists' version of events in the wake of the 1898 race riot. These accounts documented the purported aggression of Wilmington's African American community and depicted the white supremacist brigade simultaneously as political revolutionaries in the process of overthrowing an unqualified and oppressive black regime and as the justified defenders of a specific version of law and order in which white social and political superiority remained intact. At the national level, black leaders like W. E. B. Du Bois, poet Paul Lawrence Dunbar, editor T. Thomas Fortune, and congressman George H. White, along with a minority of white supporters, fought for public recognition of the event as the racial massacre that it was, but their appeals were undercut by the lack of response from the McKinley administration, public sentiment, and a growing tendency toward assimilation rather than militancy among the black middle classes in both sections. Among white Democrats in the South, Wilmington was touted as a successful model of political method and served as a figurehead for the subsequent disfranchisement campaign of 1899-1900 (Haley 210-217). Despite resistance at both the national and local levels, the coup was successful for the white supremacist "revolutionaries," as they had dubbed themselves, and their version of events would dominate popular narratives and history books for nearly a century.

Bundled into the Democratic rhetoric of white revolution is also the white claim of defensive action or pre-emptive strike in the name of law and order, which Chesnutt refutes through his juxtaposition of the contemporary post-Reconstruction race riot and antebellum slave 
insurrection. Chesnutt reconfigures the power relations at play both in white riots and in slave insurrections and reveals a tragic and predictable continuity between the two, despite the intervention of such seemingly definitive progressive events as Emancipation and

Reconstruction. In both scenarios, Chesnutt reveals, it is the whites who revolt against their own avowed principles of law and order in their self-serving and violent subversion of black citizenship. Where Chesnutt disputes and works to reveal the inherent contradictions in white supremacists' classifications of the Wilmington violence as a combination of white revolution and black insurrection, he does, however, share with white supremacist ideologues in the prediction that Wilmington forebodes a coming race war. For Chesnutt, the US, catastrophically divided by the fictions of race, has reached an intermittent point of chaos at which the potential for real revolution becomes recognizable amid the fractured logic of the current state of American racial divisiveness.

\section{Riot}

In the olden time the white South labored under the constant fear of negro insurrections. Knowing that they themselves, if in the negroes' place, would have risen in the effort to throw off the yoke, all their reiterated theories of negro subordination and inferiority could not remove that lurking fear, founded upon the obscure consciousness that the slaves ought to have risen. - The Marrow of Tradition (276)

Contemporary literary responses to the Wilmington massacre represented diverse positions on an ideological spectrum, from that of Chesnutt in The Marrow of Tradition to Thomas Dixon Jr. in The Leopard's Spots: A Romance of the White Man's Burden, 1865-1900 (1902). The first literary representation was Hanover; Or, The Persecution of the Lowly (1900), in which David Bryant Fulton, an African American and former Wilmington resident, creates a "semi-fictional" (Lowery 416) account of the riot that begins with an 11 November report from 
the Associated Press in which "gangs of Negroes" are reported to have been "growling and threatening the whites" (Fulton 3). After a brief historical introduction, Fulton turns to a fictionalized narrative in which major white players are easily recognizable and principle black figures are identified by name. Fulton emphasizes the defensive role played by African Americans, particularly black women, during the riot, as well as the disingenuous deflection of responsibility for the violence by the white elite onto lower class whites, while adhering, for the most part, to the dominant sequence of events established in the historical records. ${ }^{6}$

The Marrow of Tradition, published shortly after Fulton's text, offers a more interpretive, ambitious, and widely circulated challenge to the dominant white narrative. In an essay published 20 October 1901 in the Cleveland World, Chesnutt would identify the "primary object" of his novel as "to entertain" and, at the same time, "to throw light upon the vexed moral and sociological problems which grow out of the presence, in our Southern states, of two diverse races, in nearly equal numbers" (McElrath, Essays and Speeches 169). Although The Marrow of Tradition was not as popularly lucrative as Chesnutt had hoped, Sheila Smith McKoy notes that Chesnutt's protest in novel form was more successful than Fulton's Hanover, because of Hanover's open reliance on the journalistic technique of eye-witness narratives: "Inevitably, it [Hanover] was easily silenced in the same manner in which the white rioters silenced the black press" (51). Alternately, Dixon's The Leopard's Spots dramatized the celebrated revolutionary narrative that was already being played out in the mainstream press. Sales of Dixon's novel of white Southern strife and national reconciliation far surpassed both Fulton's and Chesnutt's works, thus reinforcing further the power of literature to shore up a nation's faith in cherished historical narratives and myths of racial superiority. 
Later scholarly responses disputed dominant historical narratives. Helen G. Edmonds' The Negro and Fusion Politics in North Carolina, 1894-1901, published in 1951, challenged the Democratic interpretation of the riot, although the first book-length historical study, H. Leon Prather Sr.'s We Have Taken a City: Wilmington Racial Massacre and Coup of 1898, would not be published until 1984. A decade later, with Philip Gerard's novel, Cape Fear Rising (1994), the Wilmington violence made its comeback in fiction for regional if not national audiences. Largely responsible for rekindling interest in the event and in historical interpretations, Prather's text would eventually become the foundation for a growing body of historical and literary scholarship, the most versatile and influential example of which is Democracy Betrayed: The Wilmington Race Riot of 1898 and Its Legacy (1998), an interdisciplinary collection of essays by both literary scholars and historians. As this centennial collection illustrates, scholars now overwhelmingly acknowledge the appalling interpretive fallacies in contemporary records of the event.

Retrospectively recognized for the important cultural work he was doing at the time, Chesnutt explicitly points to a tradition of racial violence both in Wilmington and in the United States more generally_ “a tradition whose marrow is colonial racism," as Jae H. Roe suggests (231). When Smith McKoy observes that “Chesnutt revises Wilmington's riot history by making the white riot visible," she emphasizes the continuity of the event within a much broader American history of self-legitimating racial violence (49). The riot itself occupies a tenth of The Marrow of Tradition - the actual violence spans only 36 of 329 pages - but a small part of a novel often identified chiefly in terms of its historical link to the 1898 Wilmington race riot. ${ }^{7}$ Chesnutt's long-term focus is not on the specifics of the violence but on the multiple people and plot lines he follows throughout the narrative. In fact, Chesnutt (dis)places the riot so that it 
occurs in his novel before the election, a move Eric Sundquist credits as "revealing the violent logic of disfranchisement and Jim Crow as it was bound up with the existing legal processes of United States racial justice" (Nations 420). Chesnutt's fictional tampering with the order of history reveals a deeper historical truth behind the motivations of the white conspirators, one not adequately addressed in the mainstream media or in the official historical records. The foreshadowed election is, in fact, conspicuously absent from the novel's order of events, as Chesnutt's narrative ends with the riot and the resultant confrontation between William Miller and Philip Carteret. In The Marrow of Tradition, political equality and due process are not merely subverted but entirely erased by the overt violence of white supremacy. Cultural obsessions with blood, genealogy, and cultural legitimacy effectively displace the American fiction of true democracy.

Chesnutt's multiple plotlines and perspectives open up the term "riot" to multiple meanings and usages, thereby revealing the different forms by which violence both mirrors and begets violence across the seemingly fixed boundaries of time and space. The intersecting plotlines place the personal politics of Chesnutt's characters inextricably within the electoral politics of the city and therefore within the overarching racial politics of the state and nation. Chesnutt preserves many of the historical drama's most prominent players through fictionalized characters, as he does with the "Big Three," a composite of the historical conspirators of Wilmington's “Secret Nine." General Belmont, the consummate aristocrat, is modeled in part on Alfred Waddell, even though Waddell was never a member of the Secret Nine (Sundquist 417); Major Philip Carteret, editor of the white supremacist Morning Chronicle, is the fictional counterpart of Josephus Daniels, editor of Democratic mouthpiece the Raleigh News and Observer; and Captain George McBane stands in for Benjamin Tillman and Mike Dowling, 
leaders of the terrorist Red Shirts (441). The Big Three all get their titles from their actual or honorary service in the now-defunct Confederate States Army, and continue to assume the respect implied therein, despite the actual irrelevance of these titles in post-Reconstruction society. These characters underscore the political conspiracy behind the violence, as well as the multiple and complex manifestations of white supremacy.

McBane is a particularly disturbing example of white brutality, and his acceptance by Belmont and Carteret exaggerates the application of fictions of legitimacy along racial lines. Carteret and Belmont may not like McBane, but "they need the terrorist arm he represents" (Roe 235). Chesnutt makes clear that the differences between Carteret and McBane are superficial, despite Carteret's insistence otherwise. When the anti-lynching editorial is first published by Barber, black editor of the Afro-American Banner (a stand-in for Alexander Manly and his paper, the Wilmington Record), McBane immediately advises violence: “"I say lynch the nigger, break up the press, and burn down the newspaper office,' McBane responded promptly" (Chesnutt 86). Carteret sees McBane as vile and tactless, yet he admits to sharing McBane's sentiments, "though he would have expressed them less brutally" (87). Carteret's insistence that they withhold the editorial is less immediately severe and certainly more calculating, but both men contribute equally to the violence at novel's end. Carteret allows the "demonstration" to be set in motion, and he only makes cursory objections to the violence when it swells beyond his control, when it is too late to stop the bloodshed. He does not object to what he sees as necessary violence against the African American men who resist his authority, but he is outraged when the violence extends to black women and children, even to his own family's faithful servant, Mammy Jane. McBane's presence among the Big Three is representative of the commodification 
of legitimacy that occurs when previously shunned and undesirable groups, like lower class whites, are granted a degree of social and political legitimacy in exchange for their loyalty.

Making explicit several distinctly different manifestations of the term riot, which are both historically contingent and particularly dependent upon who is supposed to be rioting, Chesnutt lays bare racialized methods of classifying violence as defensive or aggressive, as resistance or rebellion. The ongoing feud between McBane and Josh Green further exemplifies the fictions of social legitimacy and their extension to the realm of violence, or vice versa, as the personal conflict between Green and McBane contributes directly to the actions of both men during the riot. When Green was ten years old, a group of Klan members murdered his father and tortured his mother into insanity while he hid in the bushes near their home. He recalls that the leader's mask slipped and he saw McBane's face. Green's recollection of this experience as "branded on my mem'ry, suh, like a red-hot iron bran's de skin," explicitly connects the postbellum violence of McBane and the Ku Klux Klan with the rituals of slavery in the image of the branding iron (111). At the same time, this image equates the psychological and emotional violence experienced by Green and his mother to the physical violence that caused the death of his father and to the physical and emotional violence of slavery. Under the system of slavery, branding of slaves and other physical, mental, and spiritual punishments were given the lie of legitimacy by the power of law. Here Chesnutt observes the changing discourse and the simultaneous inertia of actual changes in practice. Chesnutt's description of McBane's violent death by Josh Green's hand as "merciful, compared with the nameless horrors he had heaped upon the hundreds of helpless mortals who had fallen into his hands during his career as a contractor of convict labor" further connects convict labor to riot politics (309-310). McBane is a scapegoat for the more seemingly respectable whites, like Carteret, who avert their eyes from deplorable practices like 
convict leasing while profiting from the products. Green's final revenge is almost simultaneous with this own murder by the white mob, thereby linking the two men in death as in life.

The conflict between Green and Miller also emphasizes intra-racial tension and class difference as well as the embrasure of different methods to combat the violence and subjugation of white supremacy. In terms of the riot, Miller's resistance is more passive and focused on the ends rather than the means. He tells Green and the group of men seeking his leadership that "Alive, I may be of some use to you, and you are welcome to my life in that way,-I am giving it freely. Dead, I should be a mere lump of carrion" (282). Miller's medical career and the hospital built by his father provide him both tentative standing with the white community and a sense of purposeful contribution to the plight of his people. His lighter complexion and relative prosperity contribute to a black experience much different from Green's. Darker-skinned and impoverished, Green's resistance is overt, physical, immediate. He refuses to live another day in social, political, and economic subjugation: "I'd ruther be a dead nigger any day dan a live dog!" (284). Their roles in the riot reflect their more general social positions and personal politics. Green is the mythic folk hero, like David Walker or Nat Turner, whose "commitment to an ideology of violent resistance also virtually requires his death, just as middle-class anxiety about the 'bad nigger' as a type who would jeopardize social progress created in folklore the necessity that the black outlaw pay for his moment of heroic glory" (Sundquist 445). Miller is the middle-class accommodationist, a more moderate figure along the lines of Frederick Douglass, perhaps most closely (but not perfectly) aligned with Chesnutt's own cultural identity, although his status as a legitimate hero is also checked in the end: "Neither Miller's own philosophy of accommodation and invocation of biblical meekness, nor his anxiety about identification with 'his people,' will 
be overridden by the violent events of the Willington massacre, but his identity as the book's hero will be stringently tested" (Sundquist 440).

Through the mixed-race character of Janet Miller, Chesnutt dramatizes the complexity, and ultimately the futility, of upholding value distinctions, both personally and politically, based on the impossibility of genealogical purity, which is the very foundation of Carteret's campaign. The mounting tension between Miller's wife, Janet, and Carteret's wife, Olivia, is due to the fact that the two women share a father, Samuel Merkell. Olivia's mother is his white wife and Janet's mother, Julia Brown, is a woman who was once his slave. The undesirable but indisputable connection between the two women haunts them both, but Olivia in particular is paralyzed by her obsession with Janet. Janet is for her the haunting reflection of herself in blackface. As Major and Mrs. Carteret discuss the possibility of Merkell's having left a will, Major Carteret outlines Janet's precarious position for his wife: "Who was she, to have inherited the estate of your ancestors, of which, a few years before, she would herself have formed a part?" (256). At various times, depending on the political climate, Janet has been both property and person, inheritance and potential inheritor. Janet's personal and political identities as a mulatta situate her as intermediary, both between black and white and between private and public discourses. At once Olivia Carteret's sister and the target of Major Carteret's violent expulsion campaign, she is living evidence of the incongruent social politics of the New South.

John Delamere and his grandson Tom further embody the clash between the Old and New South. Mr. Delamere represents a sympathetic white elite and a passing generation of Southern "gentlemen." He subscribes to an antiquated code of honor in which the division of social roles along racial lines is accepted, but, at the same time, loyalty is rewarded, laws are respected, and whites, for the most part, take seriously their self-appointed accountability to a 
subservient race. While he stands out as a moral voice among his peers, he continues to exhibit a troubling sense of paternalistic responsibility. In contrast to his grandfather's moderate and potentially redemptive character, Tom's gambling, stealing, and disregard for all codes of moral conduct and for human life, white or black, is more sharply distinguished. His blackface impersonation of Sandy Campbell, which begins as a seemingly harmless mockery at a church bake sale, escalates to his calculated framing of Campbell for the murder of Polly Ochiltree when he attempts to rob her while dressed in blackface and in Campbell's clothes. Tom's crime, and the pursuant near-lynching of Campbell, Mr. Delamere's loyal servant, provide fodder for the white supremacy campaign already underway. Mr. Delamere's dogged defense of Campbell and attempts to stop the lynching deprive the white mob of a scapegoat, delaying their satisfaction until the eve of the election.

In identifying the Wilmington riot as revolution, Chesnutt employs the Democrats' own terminology to bring the white riot to the forefront and to reveal the self-legitimating circular reasoning behind the rhetoric of justified white revolution. The inter-connected plot lines ultimately converge in the riot near the novel's end, which the conspirators both anticipate and even welcome, according to their terms. While violence may be messy and uncomfortable for Carteret and Belmont, they cannot fool even themselves in denying that they expect resistance and are prepared to address that resistance with violence. Carteret describes the actions of the Big Three, both in their deliberate manipulation of the community's fears and passions and in the anticipated confrontation, as both glorious and defensive: "We wish to right a wrong, to remedy an abuse, to save our state from anarchy and our race from humiliation. I don't object to frightening the negroes, but I am opposed to unnecessary bloodshed” (250). Here Carteret implicitly admits his own sense of control over the outcome of the event, reflecting the sense of 
control shared by the Wilmington Secret Nine, and paradoxically acknowledging that he is responsible for whatever may come of his carefully engineered scheme, whether success or tragedy. McBane's reply to Carteret's insistence that no "premeditated murder" be committed is that he'll personally "pay for burying all the niggers that are killed," a statement that clearly indicates the emptiness of Carteret's hope for a peaceful resolution while it also reveals the importance of performing a rhetoric of justified revolution even among themselves (250).

\section{Revolution}

The conspirators were jubilant at the complete success of their plans. It only remained for them to so direct this aroused public feeling that it might completely accomplish the desired end,- - to change the political complexion of the city government and assure the ascendancy of the whites until the amendment should go into effect. A revolution, and not a riot, was contemplated.

- The Marrow of Tradition (249)

There is more at stake in Chesnutt's distinction between "revolution" and "riot" than historically accurate terminology. In structurally placing the two terms back to back and in opposition to each other, Chesnutt configures revolution and riot as mirror images alternately reflecting the ostensibly rational, legitimate, sanctioned violence of the majority and its converse, the irrational, illegitimate, disruptive violence of riot by an unsanctioned minority. Where Chesnutt wants to blur the distinctions implied in these apparently oppositional terms, Wilmington's white supremacists worked to solidify their segregated usage along racial lines. Inherent in the white supremacists' use of the term revolution is the suggestion of legal and political imbalance, specifically, that African Americans were somehow taking over Wilmington's local government, treating the white citizens unfairly, and depriving them of their natural rights. With a nod to the Revolution of 1776, white supremacists conjured images of their own oppression at the hands of a tyrannical foreign government, for they were unprepared and 
unwilling to accept African Americans as legitimate US citizens. The rhetoric of revolution obscures the fact that the white violence was, in fact, a pre-emptive strike, indeed, a coup, which displaced the city's duly elected black officials and replaced them with white Democrats.

In order to justify their "revolution" as reactive rather than proactive for a national audience, local white supremacists played on well-established racial animus and complementary fears of black aggression and "negro domination." The perception of black-on-white violence was the big news rather than the forceful overthrow of Wilmington's democratically-elected Republican government. Reports in the contemporary white press immediately following the riot ignored this immediate history as well as the prehistory of slavery, subjugation, and lynching entirely and depicted Wilmington's black community as unprovoked, savage, bestial, and lawless. At the same time, whites were portrayed as the virtuous victims of and respondents to random black violence. This headline from the Raleigh News and Observer (Nov. 11, 1898) —“A DAY OF BLOOD AT WILMINGTON: Negroes Precipitate Conflict by Firing on the Whites"situates the responsibility for the violence exclusively with the African American community ("For the Record"). The use of so general a term as "conflict" implies a lack of accountability on the part of the whites involved and considers the violence a more general, ahistorical clash between two groups. The ongoing intimidation and election fraud perpetuated just days earlier, on 8 November, fail to warrant a mention.

Initial reports not only made editorial distinctions between the behavior of the whites and that of the blacks on 10 November, but they effectively constructed two separate events in the physical eruption of violence and the political revolution. Next to this article-which carries the secondary headline "No Further General Violence Feared"-appears a picture of Alfred M. Waddell, with a caption that reads: "HON. ALFRED MOORE WADDELL; The New Mayor of 
Wilmington Who was Elected Yesterday," as though the two are separate and distinct, as though Waddell's election is, in fact, not part of the same story as the riot, which, according to this report, occurred on the same day ("For the Record"). The phrasing of this headline illuminates an interesting discrepancy in the historical record, because the official (if fraudulent) elections were held on 8 rather than 10 November. This article virtually admits that Waddell's "election" was the result of fraud and violence rather than popular vote. This small detail, however, mattered little in terms of public opinion, because the coup had already been successful.

The timing of these events, on the other hand, factored heavily into the white supremacists' claims of defensive action. Headlines like this one from the Wilmington Morning Star (Nov. 1898) — “BLOODY CONFLICT WITH NEGROES. White Man Forced to Take Up Arms for the Preservation of Law and Order. BLACKS PROVOKE TROUBLE"-would have carried less weight had the "white man" not so recently reasserted himself as officially representative of "law and order." This declaration both implicitly celebrates the success of the white supremacist "revolution" and justifies the white violence as a pre-emptive strike. The secondary headline here reads "The Whites Fired Upon by Negroes - The Firing Returned," clearly excusing the white violence as a defensive response to unmitigated black aggression ("For the Record"). Again, the white press, in depicting the riot, identifies an ahistorical black antagonism as the cause of the violence through its presentation of the event in isolation. In fact, the white press not only isolated the riot, they also isolated parts of the event, choosing to begin their report at the point that the African American community took up arms in defense of their lives. Any violence, whether threatened or actual, on the part of the white community before that point is obscured by these reports, and any violence afterward is explained away as defensive, justifiable, and legitimate. 
The white supremacist rhetorics of revolution and of preventative violence overlap in contradictory and inconsistent ways and illustrate the ability of the dominant group to manipulate the terms of their own violence. Waddell's version of the story, ghostwritten by Charles Francis Bourke and printed in Collier's Weekly on 26 November 1898, subjugated the violence of the riot to the political outcome in an interesting inversion of the tenor of these earlier accounts (Wilson 107). Identified in the byline as "Leader of the Reform Movement and now Revolutionary Mayor of Wilmington," Waddell issued an interpretive statement clearly intended for a national audience ("The Story of the Wilmington, N.C. Race Riots") and representative of what would become, according to the Final Report of the 1898 Wilmington Race Riot Commission, the "standing story — [that] whites performed an act of revolution to wrench the city from the brink of lawlessness and chaos" (205-206). Waddell's claim that the "government we have established, it is a perfectly legal one," justifies his actions, and those of his coconspirators, by characterizing both their motivations and ensuing actions as purely political, and, in contrast to the connotations of the term "riot," both deliberately controlled and within the bounds of law. It is important to note that in identifying the event as a revolution, Waddell is at once claiming agency and responsibility for the political success of white supremacy and aligning Wilmington's black community with the violence and chaos the white Democratic revolution claims to have eliminated. In calling it a revolution, Waddell, who also mixes up the timing of the events, is limiting his own accountability and the accountability of the white mob. He presents the damage of the riot as collateral, secondary and necessary to the political goals he and his co-conspirators have achieved, and deflects responsibility for it onto the displaced minority group. 
In the press, white supremacists denied responsibility for any violence on the grounds that they were simply mirroring the violence of the enemy, countering the actions of Wilmington's black community. Chesnutt draws that mirror outward to reflect an immediate prehistory of conspiratorial design within a larger tradition of American racial subjugation and violence. In its presentation of a more contextualized perspective, Chesnutt's fictional version of events makes clear that these distinctions, between revolutionary and riotous violence, are social constructs, that the fiction of legitimate revolution is drawn along the same lines as the fiction of race. In fact, race is revealed as the site of distinction between legitimate and illegitimate violence.

In The Marrow of Tradition, Chesnutt refutes the media's presentation of two separate but simultaneous events by pointing to the construction of artificial boundaries along racial lines and emphasizing the continuity of the proceedings. The chapter titled "Mine Enemy, O Mine Enemy!",8 begins with this telling description of the progression of events leading up to the violence of the riot: "The proceedings of the day—planned originally as a 'demonstration,' dignified subsequently as a 'revolution,' under any other name the culmination of the conspiracy formed by Carteret and his colleagues - had by seven o'clock in the afternoon developed into a murderous riot" (298). Here Chesnutt does several things. First, in outlining the different names applied to the same series of events at different points in the course of a single day, he collapses the demonstration, the revolution, and the larger conspiracy into one event - the riot. Second, his emphasis on the progression of events belies the implication of a spontaneous eruption of violence on the part of the blacks. That is, the origins of the violence can be traced back to the morning's "demonstration" by the white Democrats, which can be traced back to the ongoing conspiracy of the Big Three, which can be traced back beyond the frame of the event or even of 
Chesnutt's narrative. Third, Chesnutt suggests that the Big Three anticipate the transition from their clandestine plotting to overt violence in the streets of Wellington and follow through regardless of the inevitable consequences. Chesnutt highlights this foreknowledge with his choice of the word "developed" rather than "devolved" or "deteriorated" to mark the significant transition into unchecked mass violence. While "devolved" might have indicated an accidental descent, a falling apart, an unintentional loss of control, “developed” subtly designates a predicted escalation.

Chesnutt is careful to place any retaliatory black violence well into the progression of the riot and to emphasize the inevitability of the white conspirators' actions to lead to violence. For Chesnutt, the riot effectively begins when at "three o'clock sharp the streets were filled, as if by magic, with armed white men" (274). The next description of the event comes when Watson, "the colored lawyer," meets Miller on his way out of town and reports what he has seen: "The white people are up in arms. They have disarmed the colored people, killing half a dozen in the process, and wounding as many more. They have forced the mayor and aldermen to resign, have formed a provisional city government à la française, and have ordered me and half a dozen other fellows to leave town in forty-eight hours, under pain of sudden death" (279). Watson's reference to the troubled and brutal history of the French Revolution invokes the inherent contradictions of challenging governing authority in violent ways, despite claims of justification. ${ }^{9}$ That all of this occurs, including the forced expulsion of the Republican government, prior to the armed stand taken by Josh Green and his fellow blacks (the only scene of aggressive, violent action by a group of blacks in the novel) points to the fact that the riot functions as a cover for the political coup, not the other way around, as reported by the white press. 
Chesnutt's use of the term "revolution" mocks statements like Waddell's, which rely on the patriotic connotations of "revolution" in order to hide the violent methods of the white supremacist community behind their ultimate political achievement. Chesnutt's language_-"until the amendment should go into effect" (249) - clearly identifies the action taken by the white conspirators as an attempt to subvert the due process of law, to, in fact, subvert the very legislation, the Fourteenth and Fifteenth amendments to the Constitution that granted the franchise and the right of due process to African Americans, with other (state) amendments that would effectively nullify them. Whereas Waddell presents the revolution as a just one, Chesnutt reveals a complex set of manipulations on the part of the "Big Three" and the use of violence as a substitute for legislation.

Chesnutt's dramatization of the conspiratorial workings of the Big Three is important because it redefines the origins of the event and exposes the white riot as the only riot. More significantly, it establishes the thought processes and cultural norms that create the potential for the eventual success of the white supremacist conspiracy. We see in Chesnutt's fictionalized rendering of the Big Three's discretionary tactics that the targeting of specific members of the African American community was, in fact, less discriminatory than a strategic attack on the community as a whole. Belmont and McBane have already settled on the black editor Barber as a target for their "demonstration." Belmont decides, too, that "that yellow lawyer, Watson" must go, because he's "altogether too mouthy, and has too much business" (250-251). Watson's crime is taking "their legitimate source of income" from white lawyers (251). For the same reason they must get rid of "that damn nigger real estate agent," whom McBane identifies as having taken "most of the nigger business" from a white agent (251). Both Belmont and McBane emphasize the right of white businessmen to earn what they call a "legitimate" living off of the black 
population. In no way do Belmont and McBane consider the rights of black businessmen to earn a living, or the rights of black citizens to choose their own representatives in the spirit of free commerce. These men are specifically targeted, because they offer alternatives to the injustice and fraud perpetrated by men like Belmont and McBane against the black community and, in turn, threaten the livelihood of white Wellington.

Belmont and McBane do not limit their attack to black Wellingtonians, but include their white supporters as well. While they may not have been made overt targets of the actual physical violence, Belmont emphatically asserts that "every white Republican office holder ought to be made to go. This town is only big enough for Democrats, and negroes who can be taught to keep their place" (251). The Big Three and their white supremacist supporters have an antebellum way of life in mind, and they intend to reclaim and preserve that way of life by forcefully ousting anyone, white or black, who does not acquiesce to predetermined social roles.

While the Big Three expand their list of victims to include white offenders as well as black, the white supremacist leaders also narrow their list, declining to target certain blacks who uphold the desired social hierarchy and those whose political positions might draw attention to their scheme, like the federally-appointed collector of the port. ${ }^{10}$ This includes the "nigger preachers," who, according to McBane, "want to stay here, where the loaves and fishes are" (251). The preachers can be bribed, McBane asserts, and allowed to remain in exchange for publicly supporting the white supremacist cause. Dr. William Miller is also spared the wrath of General Belmont, because his spending money in the community "contributes to its prosperity," but, because of McBane's aversion to "smart niggers" and Carteret's admittedly personal dislike for him, Miller is ultimately targeted for expulsion (252). That their personal grudges affect their political decisions is a knowledge that lingers in the air until it is released by the offensive 
Captain McBane: “"What's the use of all this hypocrisy, gentlemen?' sneered McBane. 'Every last one of us has an axe to grind! The major may as well put an edge on his. We'll never get a better chance to have things our way. If this nigger doctor annoys the major, we'll run him out with the rest"' (252). Such consciousness both of personal grievances and of the possibility of exposure point to the duplicity of the Big Three in their idealized re-making of the population of Wellington. While their targets may indeed have been chosen carefully and their intended victims limited to those who had offended them in some way, however unrealistic, both their intentions and eventually their violence would spread to the whole of Wellington, beyond even the black community. Their obvious desire for some measure of secrecy and for avoiding legal interference from without signal a clear knowledge that their behavior would not have been universally condoned by a national white audience, especially if it were revealed that their careful targeting of perpetrators was not as discriminating nor as restrained as they wished to project.

The purported legitimacy of the white supremacist mission, including public acceptance of the conspirators' actions as legitimate, is also dependent on the public perception of spontaneity, although the rhetoric of justification is a way of validating actions already in place. The white press's separation of the events along the lines of violence (riot) and politics (revolution) carries with it the implication of different degrees of spontaneity and planning. The marking of the violence as spontaneous, as disordered, as black, effectively differentiates it from the necessary collateral violence of revolution and further justifies the white violence against an immediate and unforeseeable threat. Chesnutt breaks down this myth of separation by directly connecting the planned revolution with the outbreak of physical, uncontrolled violence and, more importantly, its conspirators with the knowledge that the revolution would inevitably culminate 
in this kind of unchecked mayhem. The Big Three's presentation of their intentions as a relatively orderly demonstration, then, in which only specific (implicitly guilty) perpetrators were targeted, rather than the entire African American community, inserts the disruptive and spontaneous black violence of riot into an otherwise tidy and disciplined white confrontation, thus defining their own actions as legitimate and normative.

\section{Insurrection}

"What's de trouble, suh? Why, all hell's broke loose in town yonduh. De w'ite folks is riz 'gins' de niggers, an' say dey 're gwine ter kill eve'y nigger dey kin lay han's on."

- The Marrow of Tradition (277)

In Wilmington, the white supremacists' public presentation of the white riot as a justified, popularly sanctioned revolution is dependent upon the fabrication of an imminent threat by an enemy other. In the normative discourse of a white supremacist society, the enemy of legitimate revolution is almost always the non-white racial other. As Smith McKoy observes, "when race is coupled with violence, the national inclination is to blacken the violence, even when that violence victimizes communities of color" (12). In The Marrow of Tradition, Chesnutt emphasizes the fluid form and repetitive function of this national phenomenon by explicitly juxtaposing the post-Reconstruction (white) race riot with the antebellum slave insurrection. Chesnutt's phrase "De w'ite folks is riz" points to a specific history of differentiating between legitimate (white) and illegitimate (black) violence at the same time as it dramatizes the continuity of racist discourse, ideology, and practice across ostensibly inviolable historical and legal boundaries. The mirror-image comparison between white riot and the suppression of real or imagined antebellum slave uprising illustrates the power politics at play in North Carolina in 1898. 
Chesnutt's juxtaposition of slave insurrection and white riot equates fundamental aspects of the two types of violent uprising, thereby revealing the cultural mechanisms that allow for the placement of fault for white violence against blacks with the black community. In terms of real insurrectionary violence, like the uprisings led by Denmark Vesey (1822), ${ }^{11}$ Nat Turner (1831), and John Brown (1859), revolting slaves and all associated with them were inherently defined by their slave status as illegitimate and therefore criminal and deserving of all violent retribution, both legal and extralegal, enacted by the white "victims." However, as Saidiya Hartman observes, it "is a tricky matter to detail the civil existence of a subject who is socially dead and legally recognized as human only to the degree that he is criminally culpable" (24). In other words, slaves, and even free blacks, held criminally culpable in instances of real or suspected insurrection could not be, legally or socially, victims themselves; they and their supporters were always already the criminal party in any altercation with the dominant white majority. In fact, as David Grimsted's account of the mayhem following Turner's insurrection documents, one did not need to be personally involved with the insurrectionary violence to bear the brunt of white retribution: "The mass killing and sadistic maiming of blacks began after the militia units arrived in the area to find most of the guilty jailed or dispersed, though Turner was still at large. Those killed and hurt after the rebellion's suppression were innocent victims of white citizens who exorcised their horror through atrocities on stray blacks" (136-137). That white violence against blacks continued, moreover intensified, after the militia arrived, as it did in Wilmington, points to the significant fact that the militia functions in collusion with the extralegal activities of the whites and its presence not only ensures their protection but also visibly justifies their continued aggression against blacks. 
Real insurrectionary violence by slaves and free blacks was much less frequent in the antebellum period than were insurrection scare panics and the ensuing white riots in which whites anticipated and punished black offenders even before an alleged insurrection took any physical shape. While Grimsted describes the insurrection scares as white riots, he also acknowledges that they would not have been so defined in the minds of white Southerners: “Doubtless slaves plotted other uprisings, but the records about other 'insurrections' testify to white fears rather than black action. The number of victims killed in these scares proclaims the depth of Southern fears about their slave population. Although there were only thirty-five instances of extralegal action against alleged insurrectionary plots, 448 persons were killed, 447 of them mob victims. Of these only 26 were whites and but 8 statedly free blacks" (135). Like the continuation of white violence against blacks after the immediate threat has passed in instances of documented black uprising, the ratio of white to black victims in insurrection scare riots clearly identifies these events as instances of white aggression. White fear of black violence provides adequate and acceptable justification for extensive and exaggerated white violence against blacks in a reoccurring pattern of deflecting the responsibility for white violence onto its black victims. The formula by which many insurrection scare riots unfolded provides a template for the later deflection of responsibility onto minority groups in the post-Reconstruction race riot and in the ritual of lynching. Grimsted observes that "Southern mobs always offered 'proof' of guilt which no one could doubt: victims were 'whipped until they confessed' — and implicated others, as the mob suggested" (15). In formulating the Wellington event in terms of a white uprising, Chesnutt evokes this specific pattern of white instigation and deflection, therefore making a distinct if subtle connection between antebellum "insurrections" and the postReconstruction Wilmington/Wellington "race riot." 
Like the slave population in the antebellum South (as well as the free black population in the North), the African American population of Wilmington in 1898 functioned as a continuous threat to the sovereignty of white Democrats. The very presence of black Wilmingtonians was a constant reminder of the fragile fictions of racial superiority on which the foundation of white supremacy was based. White Democrats saw conspiracy around every corner, especially in the Fusionist coalition of Populists and Republicans. As Sandra Gunning observes, "whereas the years prior to Emancipation were marked (often, though not exclusively, in the South) by organized white violence against African Americans under the rubric of punishments necessary for slave discipline, after 1865 white-on-black violence came to be seen as urgently selfdefensive" (6). In antebellum America, slaves deprived of all social and political power still posed a specifically violent threat to a white community literally lording over them. In postReconstruction North Carolina, that threat came in the form of black political and social achievement. Therefore, black violence and black political power are again conflated in terms of dominant interpretations of the events; socio-political "insurrection" is interpreted under the same rubric as slave insurrection. As in real insurrections like Nat Turner's, black violence and black political power are necessarily compressed, because slaves were by definition denied any form of social, economic, or political existence. Arguably, violence was their only recourse to the injustice of slavery. In Chesnutt's configuration, the political achievement of black Wellingtonians is equal to violence against whites in the eyes of white Democrats. In both Wilmington and in Chesnutt's fictional Wellington, white subversion of the Reconstruction amendments, disfranchisement campaigns, and defamation campaigns in the white press effectively reconstituted black politics in terms of black violence, recreating the threat of violent, “illegitimate" insurrection in a post-Reconstruction setting. 
In The Marrow of Tradition, the attempted lynching of Sandy Campbell stands in as a microcosmic representation of the formulaic and ritualized deflection of white violence onto the black community. Through the specific aspects of Campbell's plight, Chesnutt implicitly connects antebellum and post-Reconstruction configurations of white riot and mob violence with intermediary (and continuing) acts of lynching. Because the physical expression of the mob's anger is focused on one individual as representative of the group rather than the entire group as a whole, the internal lynching drama focuses in on and explicates the fundamental elements involved in the evolution of a race riot, whether or not that riot takes the specific form of slave insurrection, lynching, or urban massacre. The progression of events leading up to Campbell's near-lynching exposes the ritualized, performative, and regenerative nature of these seemingly disparate events as part of the continued maintenance of white supremacy.

Even before mob violence becomes a bloody reality for Chesnutt's fictional Wellington, we see in Campbell the literal criminalization of a black man by white violence. This sequence of events evinces many of the classic elements of racial (il)legitimacy, criminalization, and deflection of responsibility. When the white Mrs. Polly Ochiltree is found lying dead, in a pool of her own blood, robbed and apparently murdered, the white people of Wellington immediately suspect that the perpetrator is black. Through his narrative voice, Chesnutt observes that this conclusion might have been logical based on sheer numbers, as "the population of the town was a least two-thirds colored" (179). However, we see that this logic is not a factor at all. Rather, the race and status of the victim are key in characterizing both the crime and the criminal. Major Carteret's white supremacist newspaper, The Morning Chronicle, describes the crime as "an atrocious assault upon a defenseless old lady, whose age and sex would have protected her from harm at the hands of anyone but a brute in the lowest human form" (185). That "brute" is 
implicitly black, which follows that rape must have been an element of the crime, although there is no evidence to support this conclusion. Angela Y. Davis emphasizes this assumption as a myth that "has been methodically conjured up whenever recurrent waves of violence and terror against the black community have required convincing justifications" (173). Both Davis and antilynching crusader Ida B. Wells note the abrupt onset of the specter of the black rapist in the postReconstruction period. The rape of white women by black men was considered neither a significant image nor worrisome problem during slavery, and black men did not systematically begin raping white women after Emancipation. As Gunning rightly asserts, this "translation of the freedman's impulse toward democracy into ultimately a threat against the most personal, most sacred aspect of white life meant that what might have begun in the late 1860 s and 1870 s as a political struggle was increasingly characterized by the late 1890 s as a social rape, an encroachment on the sacred Anglo-Saxon right to everything in American society and civilization" (7).

Sandy Campbell is charged with the literal rape of Polly Ochiltree, although no one, including the Big Three, is terribly concerned with the details of the case. Campbell's guilt is established by the accusation, and the accusation establishes his guilt. In the pathology of the lynch mob, guilt and punishment were not necessarily reconcilable. According to W. Fitzhugh Brundage, it "was not essential to mob members that their victims be actually guilty of a crime, but it was important that some sort of infraction had taken place" (Lynching 49). Punishment becomes an easy mechanism once a defendant has been established. McBane's sweeping generalizations based on the racial identity of the victim and the supposed racial identity of the criminal solidify the connection between the literal rape of which Campbell is accused and the social rape for which he is being punished: 
"Burn the nigger," reiterated McBane. "We seem to have the right nigger, but whether we have or not, burn $a$ nigger. It is an assault upon the white race, in the person of old Mrs. Ochiltree, committed by the black race, in the person of some nigger. It would justify the people in burning any nigger. The example would be all the more powerful if we got the wrong one. It would serve notice on the niggers that we shall hold the whole race responsible for the misdeeds of each individual." (182)

The purpose of McBane's proposed burning spectacle is not to punish the guilty but to instill fear and anger toward blacks in Wellington's white population and to terrorize the black population. In terms of the lynching ritual, murder was not the sole purpose of the punishment: "Most mass mobs had didactic aims; their actions both conveyed the degradation that they believed their victim deserved and underscored the legitimacy of the extralegal execution" (Brundage 39). The performance of the lynching ritual established the guilt of the accused while reinforcing the need for conspicuous retribution. Punishment of the crime, for McBane, as well as for perpetrators of many contemporary lynchings, was merely a tool for the furtherance of domestic terrorism and the use of force to enable political goals.

The need for spectacle as it repeatedly occurs in the lynching ritual, for the performance of white supremacy, explains the continuation of excessive white violence against blacks well beyond (or in the absence of) any immediate threat from revolting slaves, and, in terms of the Wilmington riot, the massacre of black citizens who had, for the most part, drawn back from the polls and even left the city with the sense of impending danger. The performance of crime, criminal, and guilt, enacted by the circular violence of lynching, of slave insurrections, and of race riots, both established the "legitimacy" of white supremacy and the "illegitimacy" of the 
racialized Other. As Michael Hatt argues, lynching is a performative ritual, replacing "moral or juridical debate" (80), a type "of utterance [which] enact[s] rather than describe[s] or name[s]" (76). The performance of the lynching ritual perpetuated a vicious, self-sustaining cycle of black criminalization. If blacks are lynched, it must be because they are guilty. If they are guilty, then they must be lynched. As Trudier Harris, Hatt, and others have determined, the ritual was established by the "frequency of repetitions" and the eventual commonplace nature of the performance (Harris 3). The lynching ceremony typically included a large crowd "in a mood which bordered upon hysteria"; the hanging, burning, shooting, torturing, or castration of a black man or woman by white men, women, and children; and, frequently, the bringing of food and taking of body parts as souvenirs (6). The mutilation of the body and the taking of souvenirs dehumanized the victim, while the presence of white children and the picnic atmosphere further established the normalcy of the event. In reducing its black victim to object, the white mob reinforced its own subjectivity: "The mob does not simply wish to see a dead black body, since this implies the absence of a living subject, but seeks to reduce the body to dead flesh, to a form that is unrecognizable as a person" (Hatt 81). Lynchings by mass mobs "helped to create a climate in which other lynchings, even when unaccompanied by ritual, could seem legitimate" (Brundage 44). These elements combined in order to reinforce a cultural norm that reached well beyond the specific victims of actual lynching and further dehumanized a newly codified citizenry.

Of course, the ritualized, spectacular, and exaggerated punishment of antebellum slaves provided the precedent for white supremacist identification of their own postbellum violence as revolutionary in opposition to the riotous, insurrectionary, and inherently criminal violence of blacks. As Chesnutt reveals, these seemingly disparate forms of racialized violence are 
interconnected in that they not only punish the accused but they establish a pattern for the continued dehumanization of non-whites. Guilt is established by the accusation, the accusation stands because of the non-personhood of the accused, and an excessive and public punishment ensures that the cycle will repeat with the next accusation. The ritual further identifies the extralegal violence of the whites as legitimate and normative, thereby stripping blacks of any and all form of recourse against white terror. Hartman accordingly describes the transition from slavery to freedom in terms of dominant white conceptions of racial difference and the law:

The legacy of slavery was evidenced by the intransigence of racism, specifically the persistent commitment to discriminatory racial classifications despite the prohibition of explicit declarations of inequality or violations of life, liberty, and property based on prior condition of servitude or race. On one hand, the constraints of race were formally negated by the stipulation of sovereign individuality and abstract equality, and on the other, racial discriminations and predilections were cherished and protected as beyond the scope of law. (121)

Even in the post-Reconstruction period, when federal laws have been established to formally incorporate former slaves and their descendants into the voting citizenry, extralegal white violence stands in as a regulating mechanism for white supremacy.

Chesnutt defines popular conceptions of and justifications for mob action in relation to the law through the character of Judge Everton, representative of relatively sympathetic white legal authority, to whom Miller and Watson have gone for help in saving Campbell from the lynch mob. Everton "admitted that lynching was, as a rule, unjustifiable, but maintained that there were exceptions to all rules, - that laws were made, after all, to express the will of the people in regard to the ordinary administration of justice, but that in an emergency, the sovereign 
people might assert itself and take the law into its own hands, - the creature was not greater than the creator" (193). Here Chesnutt replicates the white supremacist authority's likening of itself to a "sovereign people" in order to reveal the arbitrary application of the law by whites. Everton's evocation of an "emergency" to which the sovereign (white) people must respond is both typical of and central to the fiction of exclusive white legitimacy and the maintenance of "true" revolution in the face of discounted violence. It allows for the classification of extralegal aggression by whites as exceptional, as aberrant, and as responsive to an urgent threat rather than as a centuries-old form of social control and domination. As Everton's statement makes clear, extralegal white actions are validated as legitimate because the situation is emergent; the law has either failed or been slow to respond to white demands, leaving them to fend for and to physically defend themselves.

The rush to execute Sandy Campbell and the corresponding non-punishment of young Tom Delamere once his guilt is realized point to the freedom of whites to do violence against others without fear of consequences. As Carteret's handling of the evidence presented to him by old Mr. Delamere implies, consequences for whites disrupted the fiction of inherent white superiority. Campbell's innocence and the absence of sexual malice are finally recognized when Lee Ellis realizes his misidentification of Campbell on the night of the murder, and that he had, in fact, seen Tom wearing blackface and dressed in Campbell's clothes. This information, when brought to Carteret by Tom's grandfather, provokes an intense dilemma for the Big Three. Carteret's prompt response to Delamere's allegations against his grandson is that "a white man must not be condemned without proof positive," despite the fact that lesser evidence against Campbell had amounted to, for Carteret, “overwhelming proofs against him" (225-226). Even more importantly, public revelation of Tom's guilt would reflect unfavorably on the white 
supremacy campaign. The Big Three are quick to conceal Tom's identity and to minimize the import of the crime, reducing it from murder to robbery accompanied by accidental death. In providing Campbell with a respectable white alibi in old Mr. Delamere and identifying the real perpetrator as "some unknown man" (230), the conspirators are able to preserve their "race prestige" on which depended the "success of the impending 'revolution,' for which he [Carteret] and his confreres had labored so long" through the continued implication of the blackness of the criminal and, at the same time, forestall the lynching of a man they know to be innocent (228). Their reluctance to see Tom Delamere punished or to reveal his guilt to the community bears witness to their own active roles in the fiasco: "The white people of the city had raised the issue of their own superior morality, and had themselves made this crime a race question" (227). Any acknowledgement of Tom as the real criminal would undermine the white supremacist rhetoric and make fools of the party's leaders.

Of the sequence of events following Ochiltree's death, Chesnutt observes that "a slight change in the point of view had demonstrated the entire ability of the leading citizens to maintain a dignified and orderly process of the law whenever they saw fit to do so" (233). This arbitrary application and outright manipulation of the law and of ostensibly unchecked passions to support the white supremacist agenda is, in Chesnutt's estimation, the real insurrectionary violence captured in his novel. When he offers an alternative perspective in which the onset of white violence appears to Wellington's black community at large as an uprising of white against black, he inverts the terms of legitimate and illegitimate violence, thus identifying white violence (lynching and riot) as both extralegal and ultimately insurrectionary in terms of declared but not actual American ideals of freedom, equality, and self-governance. In revealing the process by which white violence is constructed as the mirroring of black violence, Chesnutt discloses that 
the inverse of insurrectionary white violence is legitimate black government and socio-political power.

\section{Race War}

"They'll not carry the war so far into Africa as that."

- The Marrow of Tradition (280)

In the aftermath of the Wilmington violence and in the early years of the twentieth century, the impending threat of race war became a reality for both white supremacists and proponents of African American equality. Members of both groups felt an increasing urgency for a definitive solution to the "race problem," and neither group was prepared to concede the demands of the opposition, as both Chesnutt and Benjamin Tillman, white supremacist leader and South Carolina senator, made clear in public speeches following the Atlanta "race riot" of 22-25 September 1906. Where Tillman unsurprisingly condemns acts of African American resistance as "criminal" and predicts a dramatic increase in the number and severity of race riots in the coming decade, purportedly because lynching has been unsuccessful in preventing the rape of white women by black men ("Race War is Coming"), Chesnutt praises his people for rising to the challenge. In "Age of Problems," a speech delivered to the Cleveland Council of Sociology in early November, less than two months after the bloodshed in Atlanta and in direct response to Tillman, Chesnutt admires African Americans' capacity and willingness for both economic and physical resistance: "the Negro is beginning to find himself, to become conscious of the tremendous power latent in nine or ten millions of human beings: They are beginning to resent oppression. By concerted effort, they have well nigh bankrupted a number of street railroads in the South which jim-crow them. They killed at least one white man, in the Atlanta riot" 
(McElrath, Essays and Speeches 248). This celebration of organized and violent resistance by African Americans, especially the killing of a white man, can be read as an invitation to further engagement. Chesnutt also implies that white public support of aggressive black resistance is forthcoming when he says that "in spite of surface indications to the contrary, they are making friends" (McElrath 249).

Both Chesnutt and Tillman emphasize urgency in their remarks, foreboding chaos and, ultimately, a reconceptualization of the existing social order, whether that is the expulsion of all blacks from the South and eventually from the country, as Tillman suggests, or the practical extension of "facility and opportunity ... to fill the duties of citizenship" to African Americans, as is Chesnutt's hope (McElrath 247). Where Tillman predicts race war in the form of "an immense number of bloody race riots, North and South, beside which the Atlanta riot will pale into insignificance," Chesnutt welcomes the opportunity inherent in the visible rupture of contesting and incompatible social orders ("Race War is Coming”). Importantly, both men reconfigure the battle lines so that interests are no longer determined by race but by allegiance. In placing blame on the white North for "the scheme of reconstruction," Tillman abandons the sentimental narrative of sectional reunion in a desperate attempt to preserve white supremacy as the dominant political system. His willingness to sacrifice dissenting whites, to lump them in with blacks as the enemy, reveals a fundamental dissonance between the constructed rhetoric of natural white superiority and the need to use violence to enforce it. Somewhere deep down, the very foundation of race as a "natural" measure of human difference crumbles in Tillman's rhetorical separation of race and political white supremacy. Escalating from the scripted "revolution" of the Wilmington riot, or the enactment of the "contained" threat of slave 
insurrection, race war bodes an extended chaotic interlude and the possibility of real revolution, from which anyone might emerge victorious.

In "The Future American," published in the Boston Evening Transcript on 1 September 1900, even before the publication of The Marrow of Tradition, Chesnutt articulates the need for visible rupture to occur before there can be reconciliation: "The outbreaks of race prejudice in recent years are the surest evidence of the Negro's progress. No effort is required to keep down a race which manifests no desire nor ability to rise; but with each new forward movement of the colored race it is brought into contact with the whites at some fresh point, which evokes a new manifestation of prejudice until custom has adjusted things to the new condition" (McElrath 134). Here Chesnutt acknowledges that race prejudice is custom and that custom can only be changed by openly confronting and disrupting race prejudice. Evidence of that change, however subtle, occurs in the form of conscious intent, "new manifestation[s] of prejudice," that represent conscious efforts to preserve white supremacy when individuals are forced to recognize an underlying incompatibility between avowed principles and social custom. This incoherency becomes recognizable through "outbreaks" or visible ruptures in the social order, like the Wilmington riot: "It is much easier, by a supreme effort, as recently attempted with temporary success in North Carolina, to knock the race down and rob it of its rights once and for all, than to repeat the process from day to day and with each individual; it saves wear and tear on the conscience, and it makes it easy to maintain a superiority which it might in the course of a short time require some little effort to keep up" (134). These day to day struggles place pressure on the inconsistencies of the existing social order and agitate toward the eruption of riot.

This is the essential principle Chesnutt traces in The Marrow of Tradition: the cultural transition from the maintenance of a tenuous jurisdiction over this riotous presence to a more 
fundamental loss of control over the institutional modes of violent repression. Multiple sites of rupture on a smaller, more personal scale are present in the novel, which both perpetuate and are influenced by a certain ideological environment in which avowed legal and social principles are undercut by cultural assumptions about racial difference. This day to day process of preserving white supremacy is the custom to which Chesnutt alludes in "The Future American" and in The Marrow of Tradition. This custom, or tradition, is not necessarily a matter of conscious intent or purpose in and of itself, but it shapes both individual identity and cultural process.

This is true in the case of Janet Miller, who functions in the novel as a visible symbol of the incongruent social order and also of the shame of miscegenation for Philip and Olivia Carteret. Upon discovering the written proof that Janet is Samuel Merkell's daughter by his legal marriage to Julia Brown, thus legitimate heir to his estate, Olivia Carteret is determined both to keep the marriage a secret and to preclude Janet from claiming her rightful inheritance (270271). In destroying the papers verifying the legal status of Julia's marriage, Olivia follows in the footsteps of her Aunt Polly Ochiltree, who years before, upon receipt of the same information, branded Julia a thief and turned her and her child, penniless, out into the street (137-138). Joyce Pettis connects the melodramatic subplot and the ostensibly personal actions of the women to the parallel political plot of the novel when she observes that in "choosing to ignore the legality and morality of a social institution as revered as marriage out of racial motives, Olivia and Polly reveal that they are ignoble and as fully capable of abusing power for personal position and prestige as their male counterparts. The effect of their deceitful manipulations is significantly similar to that of the riot engineered by the men" (47). However, there is more at stake here than the supposed superior morality of the Carterets, representatives of pure, white aristocracy. Olivia's actions, like her husband's in fomenting the riot, reveal a structural inconsistency 
between the rules of social and legal engagement and their application along the lines of race, which, as Janet's character illustrates, is itself ambiguous. Olivia's behavior is deceitful, but it remains in line with culturally accepted manipulations toward the maintenance of white superiority, thus both reinforcing the existing system and demonstrating the effects of its influence.

The riotous presence is essentially dormant until these cultural incoherencies give way to a conscious need to defend white supremacy, when the established system of social control, as exemplified by Olivia Carteret's systematic abuse of her sister Janet, reaches a point where it no longer seems to be working effectively. Chesnutt's analysis in The Marrow of Tradition functions by working through the layers of justification and rationalization to get at the underlying social dynamic as structural principle. Through his tracing of incoherent social patterns and cultural logics in the many intersecting plotlines and genealogies of The Marrow of Tradition, Chesnutt exposes more subtle means of consciously justifying white supremacy in many forms, including charges of "negro domination," legislative subversion of the Reconstruction amendments at the state level, grandfather clauses contrived to exclude ex-slaves and their descendants from the polls, and Black Codes, which represented a concentrated effort to combat the effects of Emancipation and actively reassert white supremacy in the South. These instances, addressed in the novel, point to similar conscious attempts to regulate challenges to white supremacy, like the Supreme Court decisions in Dred Scott v. Stanford (1857), in which the Supreme Court refused citizenship to blacks; In re Ay Yup (1878), the first prerequisite case in which racial qualifications for citizenship were decided along the lines of both "common knowledge" and "scientific evidence" (Haney Lopez 5); and the more contemporary Plessey v. Ferguson (1896), which codified the doctrine of "separate but equal." The prerequisite cases are 
especially interesting, because they not only "demonstrate that race is legally constructed," but they also reveal the inability of the Supreme Court to articulate a satisfactory definition of whiteness, the thing at stake (Haney Lopez 20). Whiteness has historically been precariously identified by what it is not, but even those distinctions do not hold, as we see in "one drop" rules and other invocations of blood purity continued attempts to define race and its cultural boundaries in increasingly absurd ways (Haney Lopez 27). ${ }^{12}$

When social, juridical, and other conscious systematic attempts to justify white supremacy fail to conceal the inconsistencies or to validate the illogical social practices they attempt to legislate, the riotous presence reaches a crisis point. It is here that it begins to manifest in the overt violence of riot. The (white) violence of riot can be conceived as revolution, to rearrange culture in such a way as to preserve white supremacy when its instabilities become both obvious and threatening, or as insurrection, to identify a threat from without. Riot can also be conceived as race war when the situation seems so dire that the cultural fiction of a stable society appears more fundamentally threatened. Riots are the "outbreaks," the "supreme efforts" of which Chesnutt wrote in "The Future American." In identifying them as different parts of an overall complex historical/cultural picture, Chesnutt goes beyond making comparisons between different categories of racial mob violence or between different manifestations of this violence in different periods of American history. Nor does he collapse all types of rupture into one amorphous category. Rather, through these juxtapositions and the eruptions of violence they represent, Chesnutt reveals an ongoing riotous presence manifest in the structural imbalances, artificial social arrangements, and basic contradictions of American socio-political and cultural life. The riotous presence is latent, becoming patent only through conscious attempts to regulate 
it, when individuals are forced to recognize the incoherency of their principles and the absurdity of their practices.

In The Marrow of Tradition, Chesnutt outlines a concept of race war as what results from the loss of control over the riotous presence. Race war tenders the opportunity for true revolution, if only because the results may not be exactly what the "victors" had in mind. At either extreme, the final result may be the suppression of the rupture and restoration of a functional but incompatible white supremacist social order, or it may be the reorganization and reconceptualization of a fundamentally different social order. On the other hand, the actual results may fall somewhere in between. In "Age of Problems," Chesnutt emphasizes the ongoing nature of the battle and the gradual nature of change:

We live in an age of social unrest - indeed every age is an age of unrest, an age of transition. If science has taught us anything, it is that constant movement, incessant change, is the law of life. ... And change involves, always, readjustment, and readjustments create problems. . . . Our Race Problem . . . is not unsolvable, but it is difficult, and we shrink from the application of the remedy. I think I see the remedy, I am sure I foresee the difficulty of its application. (McElrath 238-239)

The "remedy" for Chesnutt lies in the chaos of riot, in the battle of race war, where every point of opposition stands at least as evidence of progressive agitation and at best as the fundamental disruption of the existing power structure.

In the course of the Wellington revolution, the terms of white supremacy change, illustrating the sort of fundamental structural upset Chesnutt saw possible within the chaos of riot. In his defense of Sandy Campbell, Mr. Delamere is pitted against Carteret and his cohorts 
when the threatened lynching of his favored servant impugns Delamere's family and his honor as well as the white ideals of character he represents. His word is no longer "bond," and he sees in Carteret's actions a direct violation of the paternalistic responsibility on which he bases his own claim to white supremacy: "I fear I have outlasted my epoch,- - I have lived to hear of white men, the most favored of races, the heirs of civilization, the conservators of liberty, howling like red Indians around a human being slowly roasting at the stake" (211). Compelled to choose between a moral responsibility to his faithful servant, whom he knows to be innocent, and the social responsibility of maintaining the fiction of white supremacy, Delamere is forced to violate his principles so as to preserve them. He announces the interdependency of the two communitieswhite and black - and the damage the revolution causes to the integrity and welfare of the whites. The whites, who have defined their own superior social standing in terms of responsibility to a supposedly subordinate race now degrade themselves in the violent subversion of their own laws and avowed moral principles: “"The law,' retorted Mr. Delamere, 'furnishes a sufficient penalty for any crime, however heinous, and our code is by no means lenient. . . . It would be better to let a crime go entirely unpunished, than to use it as a pretext for turning the whole white population into a mob of primitive savages, dancing in hellish glee around the mangled body of a man who has never been tried for a crime"' (212). Twice Delamere likens the white population to "savages" in terms of their treatment of blacks, thus inverting the terms of racial superiority. Campbell, whose moral fiber remains intact and who has demonstrated his willingness to sacrifice himself rather than betray the trust of his white benefactor, has proven himself more capable of representing a white ideal character than the majority of the whites.

This fracture of white supremacy within the chaos of riot provides an entrance for other forms of social change. Delamere's fraught shift in allegiance is one example, and the emergence 
of an ideal black character in Campbell is another. The Millers also represent a shift toward an ideal black character, as the enduring animosity both Carterets feel toward the Millers is fed by the Carterets' ultimate recognizance that that the distinctions between them are superficial and that the Millers have, in fact, proven themselves to be of superior morality and determination. By their very presence, the Millers threaten to expose the Carterets, and, therefore, to expose the rhetoric behind the "white man's views of the negro"” as "a charade of several dimensions, in which the 'best people' often played the most responsible roles, as they did, for example, in the 1898 Wilmington riot on which The Marrow of Tradition is based" (Sundquist 273). The possible "corruption" of Carteret's precious familial line, as well as the literal moral corruption of the greater Carteret family's means, renders questionable the very paternalistic antebellum social system that he and his white supremacist coconspirators are trying so desperately to preserve, and are at the same time violating, with their "revolution." The supposed superior morality of the white aristocracy is further challenged during the riot when the white rampage claims as its victims Jerry Letlow and Mammy Jane, faithful servants to the Carteret family, as well as the Millers' young son. Letlow's manner of death is particularly revealing, as, upon waving a white flag of truce from the window of the burning hospital, expecting Carteret to come to his rescue, he is instead answered by "a volley of shots from the mob" (307). Chesnutt emphasizes the horrible contradiction evident in his white characters' willingness to kill blacks, including women and children, even though they have been dependent on them as childcare givers, domestic servants, confidants, and companions.

Chesnutt seems to recognize that social disorder is the normal state of affairs, that the riot is, in effect, ongoing, a continuous presence adopting different forms at different moments in time. Tom Delamere's dual blackface performances - first for a Northern audience at the St. 
James Hotel and later disguised as Campbell while robbing Polly Ochiltree-are central to the action of the novel and to a cultural climate of racial performance and social disorder. Sundquist describes Delamere's cakewalk impersonation of Sandy as "a seemingly diversionary episode" (Nations 271). However, Delamere's initial blackface act reflects a larger social condition: “In Chesnutt's use here the cakewalk functions first as a metaphor for the South's 'performance'its often disingenuous display of racial harmony and black progress, or its calculated explanation for the lack of either-before a northern 'audience,' whether in the press, Congress, in business and industry, or in literature" (273). Chesnutt's use of minstrelsy clearly evokes the dangers evident in the performance, even if on an ostensibly purely social level, of racial stereotypes and intimately connects the larger cultural adherence to predetermined social roles to the normalizing of white violence against blacks. As Sundquist notes, the two blackface acts call attention to the two available contradictory alternatives for representing blacks in the press: the "sensational journalistic image of Sandy as a brutish criminal" and the caricatured image of the minstrel, both images which preclude the ability to legitimately resist violence against person or community (423). While Delamere's cakewalk impersonation may seem diversionary or inconsequential at first, his initial minstrel act eventually leads directly to a subsequent turn in blackface and the near-lynching of Sandy Campbell, who, socially and culturally defined as illegitimate, has no recourse to stall the force of the accusations against him. The absolute willingness of both Tom Delamere and the white mob to sacrifice Campbell signals the circular nature of the performance: white violence against black people precipitates more white violence against black people.

In The Marrow of Tradition, Chesnutt establishes that culture is based on tenuous social fictions, which are maintained and strengthened in the press, in the courts, and in private homes. 
The onset of riot signals the inevitable rupture of these social fictions, and with that rupture comes the opportunity to reenvision society by more coherent principles - like returning to the basics of human sympathy and saving the life of a child. This, perhaps is the "love story with a happy ending" of which Chesnutt writes while promoting his novel in the Cleveland World on 20 October 1901: "The book is not a study in pessimism, for it is the writer's belief that the forces of social progress will in the end prevail, and that in time a remedy may be found for every social ill” (McElrath 170). Rather than end his novel with the massacre, Chesnutt elevates Miller's dilemma to the climactic point of the narrative. From the violence of riot, an opportunity has emerged in which the power dynamics are disrupted so as to be, at least temporarily, reversed; in this moment, it is Miller who holds the power of life and death in his hands. Characteristically, Chesnutt's novel finds hope in "erecting individual proofs of the positive trends he wished to identify with and sponsor" (Andrews 190). Both Carteret, in his ability to recognize the Millers' humanity, and the Millers, in their act of compassion even in a moment when they would seem justified in retribution, like Mr. Delamere before them, stand in as evidence of the possibility of reconciliation. Miller's decision to save Carteret's son, despite Carteret's responsibility for his own son's death, is both sentimental and hopeful, turning the story away from the overwhelming political and social obstacles and reinforcing the visceral and emotional human element struggling to emerge from beneath the rubble.

Following the dispersal of the white mob in the wake of the riot, Chesnutt observes that "our boasted civilization is but a thin veneer, which cracks and scales off at the first impact of primal passions" (310). This narrative intrusion is prompted by the juxtaposition of the violence of the riot, particularly the bloody climax in which both Green and McBane are killed, with the "promise of good things for the future of the city," represented by Miller's hospital, which "lay 
smouldering [sic] in ruins" (310). In these two images, Chesnutt reveals the destructive violence of riot as it lies just beneath the surface of social progress and productivity, ever present and born of the incompatible logics of ideal American democracy and functional white supremacy. In the novel, the violence of riot does not come as a surprise but functions as the exceedingly natural result of the normal functioning of such a society fractured by the constructs of social, familial, and political legitimacy based on race. If this inevitable eruption forebodes change and the eventual reconciliation of white and black, at the same time, "the application of the remedy" proves both difficult and chaotic and potentially takes the form of a drawn out and enduring war between the races, with many sacrifices to be made.

\section{Notes to Chapter 1}

${ }^{1}$ Some scholars suggest that the piece was written by someone other than Manly, although, according to Sundquist, evidence indicates that Manly wrote the article himself (To Wake the Nations 416). For more information about the historical event and political context, see H. Leon Prather, Sr. "We Have Taken a City" in Cecelski and Tyson, Democracy Betrayed (U of North Carolina P, 1998); Prather, We Have Taken a City: Wilmington Racial Massacre and Coup of 1898 (Associated University Presses, 1984); and the Final Report of the 1898 Wilmington Race Riot Commission (May 31, 2006).

${ }^{2}$ The Secret Nine, so named by Harry Hayden, a white Wilmington Democrat, were J. Alan Taylor, Hardy I. Fennell, W.A. Johnson, L.B. Sasser, William Gilchrist, P.B. Manning, E.S. Lathrop, Walter L. Parsley, and Hugh McRae (Prather, "We Have Taken A City" 20). See also Harry Hayden Papers, 7, Special Collections Library, Duke University, Durham, N.C.

${ }^{3}$ In Appendix N, “Timeline,” of the Wilmington Race Riot Commission's Report, this document is referred to as the "White Declaration of Independence" (432). In "We Have Taken a City," Prather identifies it as the "Wilmington Declaration of Independence" (29). "White Declaration of Independence” is reprinted in WRRC Final Report 115. Wilmington's black elite drafted a response to the ultimatum set forth by white supremacist leaders. However, Armond Scott, who was sent to deliver the reply in person, as ordered by Waddell, mailed it instead, probably because he was intimidated by the presence of armed white men and of his name on a list of black citizens targeted 
for expulsion (WRRC 433; Prather 31). Because the reply was mailed rather than hand-carried, it failed to meet Waddell's deadline. There is often an undercurrent of responsibility attached to reporting this detail, however, as Prather, among others, notes that the tardiness of the reply likely "only provided a convenient excuse for white leaders already bent on violence" (31).

Two versions of the response from Committee of Colored Citizens exist. The original of the letter promoted by Waddell as the one he received is in the Alfred Moore Waddell Papers, Southern Historical Collection, University of North Carolina Library, Chapel Hill.

${ }^{4}$ Prather suggests that William Mayo was killed by the first shot fired, as reported in the Wilmington Messenger, 11 Nov. 1898 (32). WRRC has William Mayo, a white man, "wounded" in the firefight, but does not note his death nor does it identify him as the victim of the first shot (start of riot) (433).

${ }^{5}$ Reports persist that there were many more black deaths than were officially recorded, including reports that bodies were buried in unmarked graves and never recovered and reports that men, women, and children, forced to flee the city into the surrounding areas, died of exposure and were therefore indirect victims of the riot.

${ }^{6}$ William Gleason asserts that Fulton's text is problematic, because it has been cited by historians, including Edmonds and Prather, as documentation of historical fact. See "Voices at the Nadir: Charles Chesnutt and David Bryant Fulton" in Critical Essays on Charles Chesnutt (ed. Joseph R. McElrath, Jr. New York: G.K. Hall, 1999. 228).

${ }^{7}$ In Sundquist's 1993 Penguin edition of the text of The Marrow of Tradition, the riot occurs on pages 247-310. In his essay for the Cleveland World, 20 October 1901, Chesnutt identifies the riot in his novel as a composite account of both the 1898 Wilmington, North Carolina, race riot of 10 November and the 1900 New Orleans, Louisiana, race riot of 23-27 July, which centered around the attempted arrest of Robert Charles: "The incidents of the race riot described in the story were studied from two recent outbreaks of that kind-one in Wilmington, N.C., and the other in New Orleans" (McElrath, Essays and Speeches 169). See also William Ivy Hair, Carnival of Fury: Robert Charles and the New Orleans Race Riot of 1900 (Louisiana State UP, 1976) and Ida B. Wells, Mob Rule in New Orleans in Southern Horrors and Other Writings: The Anti-Lynching Campaign of Ida B. Wells, 1892-1900 (Bedford, 1997).

${ }^{8}$ See Micah 7: 8: "Rejoice not over me, O my enemy! though I have fallen, I will arise; though I sit in darkness the Lord is my light" and Micah 7: 6: "For the son dishonors his father, the daughter rises up against her mother, The 
daughter-in-law against her mother-in-law, and a man's enemies are those of his household" (The New American Bible).

${ }^{9}$ See also Maximilien Robespierre, Virtue and Terror, and especially the introduction by Slavoj Žižek (Verso, 2007). Fiat Justitia is the title of Chesnutt's chapter 36, in which the Carteret family sees unexpected results of the riot in Dodie's failing health and their inability, because of the chaos of the riot, to summon a white doctor, therefore forcing Carteret's hand and sending him to Miller's door. Žižek identifies this term, in the context of the French Revolution, as "justice, the point of non-distinction between justice and vengeance, in which the 'people' (the anonymous part of no-part) imposes its terror and makes other parts pay the price—-the Judgement Day for the long history of oppression, exploitation, suffering" (xi).

${ }^{10}$ Chesnutt meticulously recreates specific elements of the Wilmington affair, as he does when he makes reference to a collector of the port, who briefly appears on the Big Three's list of blacks targeted for expulsion. In the novel, it is quickly decided that they "better not touch him. It would bring the government down on us, which we want to avoid" (251). This unnamed collector's appearance in the novel, although very brief and amid a list of other very minor characters receiving only mention, is reminiscent of historical accounts of collector of customs John Campbell Dancy, a black outsider appointed to his position in 1897 by President McKinley, taking over the job of a prominent white Democrat and earning the "exorbitant" salary of $\$ 4,000$ per year (Prather 17). Dancy, like his fictional double, attracted the wrath of white supremacists because of his enviable position and power, at the same time his external connections made him an unwise target for overt intimidation or violence. These are the details that Chesnutt is careful to preserve, the smaller and more telling elements of the overall picture neglected by the media's grand narratives of violence and white justification.

${ }^{11}$ Michael P. Johnson argues that the Denmark Vesey conspiracy was the creation of members of the court and intimidated witnesses rather than a planned insurrection in "Denmark Vesey and His Co-Conspirators." William and Mary Quarterly $3^{\text {rd }}$ Ser. 58.4 (Oct. 2001): 915-976.

${ }^{12}$ See Chesnutt's essay, "What Is a White Man?" (1889) in McElrath, Charles W. Chesnutt: Essays and Speeches. $68-73$. 


\section{Chapter 2. "From all such proffers of friendship": Dixon, Tourgée, "Brothers," and}

\section{Liberals}

The continued performance of this never ending drama has already stretched through well-nigh three centuries, with not a hint of termination. The Emancipation Problem may be regarded as the close of the first act. The Golden Jubilee of this event justifies a moment's pause for a cursory glimpse at the past, a glimpse of the present, and, if it might be vouchsafed, an inkling of the future.

-Kelly Miller, "Out of the House of Bondage" (13)

In his journals and essays, Chesnutt repeatedly classes Albion W. Tourgée’s best-selling novel, A Fool's Errand: By One of the Fools (1879) among "not a great many" other admirable "books about life along the color line and amongst the colored people," of which Harriet Beecher Stowe's “epoch-making” Uncle Tom's Cabin (1852) stands as the consummate representative (McElrath Essays and Speeches 516). Yet Chesnutt finds Tourgée's rendering "romantic" and his ability to represent the cultures of the South tempered by his "necessarily limited intercourse with colored people" and by his "limited stay in the South" (Brodhead 125). Chesnutt's qualified praise of Tourgée's fiction elicits the complex and often flawed nature of white Radicalism in the Reconstruction and post-Reconstruction periods. Despite Tourgée's explicit condemnation of racial violence and legal segregation and his important public work as an advocate for African American civil rights, there was something about Tourgée's fiction that seems to have left Chesnutt with reservations.

Popularly representative not only of different generations but of divergent racial politics, Tourgée and Thomas Dixon, Jr. occupied different ends of the political spectrum in terms of their public engagement with the "race question." By the 1890s, Tourgée had become a dogged opponent of legal segregation, which he saw as compromising rather than strengthening the Union, and his persistence made him unpopular with many who were largely ready to move on 
from the messy business of the Civil War. A Union veteran and a carpetbagger in North Carolina during Reconstruction who steadfastly refused to ignore structural reconstitutions of the principles of slavery like lynching and disfranchisement, Tourgée also served as a lawyer and as a judge and was highly respected, if disliked, for his notorious impartiality on the bench. He would later found the National Citizen's Rights Association (NCRA) in 1891, draft anti-lynching legislation for the state of Ohio, and challenge segregation at the Supreme Court level as lead attorney in the landmark 1896 Plessy v. Ferguson case. When Dixon's The Leopard's Spots: A Romance of the White Man's Burden, 1865-1900 (1902) was initially published in the US, Tourgée was serving as American consul in Bordeaux, France, where he received a complimentary copy from publisher Walter Hines Page. According to Tourgée's biographer Mark Elliott, Page probably believed that Tourgée "would find the subject matter of great interest" (17). In fact, Tourgée was so disgusted with Dixon's historical fabrications that as “copies of Dixon's novel continued to arrive at his doorstep, an increasingly irritated Tourgée picked them up with tongs and deposited them directly into the fireplace" (18).

Tourgée's aversion to Dixon's novel is hardly surprising, as The Leopard's Spots spans more than thirty years, from the close of the Civil War to the dawn of the new century, and tells an extended story of black degeneracy, white superiority, and the threat of amalgamation that Dixon would narrate again and again in his fiction. The Leopard's Spots and its sequel, The Clansman: An Historical Romance of the Ku Klux Klan (1905), provided the basis for Dixon's later career in American cinema and the screenplay for D. W. Griffith's The Birth of a Nation (1915). A respected orator at Wake Forest College and then, for a short time, a graduate student in history and politics at Johns Hopkins University, Dixon would try his hand at acting with a traveling company before becoming an ordained Baptist minister in 1886 (Gillespie and Hall 3- 
5). He also pursued relatively successful careers in politics and the law before embarking on an extremely lucrative literary career that would combine his earlier lessons and acquired skills in oratory, drama, and the Social Gospel. Dixon was not the first to romanticize the Ku Klux Klan, to represent a white supremacist ideology in fiction, or to exploit the racialized and sexualized figures of black men and of black and white women. He was, however, uniquely capable of mobilizing fiction to solidify his political agenda. Brundage traces Dixon's immense and enduring popularity to his distinctive command of melodrama's "moral transparency and urgency" which "enabled him to be heard over the cacophony of turn-of-the-century America, to reach, with unusual force, the divided minds of his generation" (“American Proteus" 32-33).

Surprisingly, Tourgée's fiction actually has more in common with the white nationalist reconciliation narratives of Chesnutt's contemporary Thomas Dixon, Jr. than with Chesnutt's own novels depicting experiences along the color line. Despite their mutual animosity and disparate politics, Tourgée's autobiographical novel, in which he maintains that "the Civil War had set his country on a course of humanitarian enlightenment and moral progress," demonstrates a narrative and ideological structure that both influenced Dixon's writing and helped to make possible the inordinate success of Dixon's white supremacist fiction twenty-three years later (Elliott 20). The novels' similarities lie not in their overt political messages but in their more subtle ideological appeals to white fraternity. These appeals undercut the trope of cross-sectional romance, advance a rhetoric of white southern honor and counterrevolution, and promote paternalistic accounts of black history which ultimately limit their visions of a changed future for African Americans. These surface similarities are apparent even as Tourgée and Dixon differ in their narrative techniques - meta-narrative consciousness and omniscient narrator, respectively - and in their presentation of existing and potential social and political relationships 
between blacks and whites. Tourgée maintains that the separation of political and social spheres is both possible and preferable, an "idea at the core of nineteenth-century American liberalism," where Dixon sees the social and the political as interpenetrating (Dailey 89). Although different, each of these perspectives contributes to the authors' understanding of national reunion as dependent upon the proper reconfiguration of white fraternity in the wake of national disunion. As David W. Blight observes, American reunion was "achievable in the end only through new regimes of racial subjugation, a fated and tragic struggle still only in its formative years. The sections needed one another, almost as polar opposites that made the center hold and kept both an industrial economy humming and a New South on the course of revival. Some of the war's greatest results, the civil and political liberties of African Americans, were slowly becoming sacrificial offerings on the altar of reunion" (139).

As with the larger social order and cultural history that these two writers struggle to represent and ultimately to shape within their fiction, the underlying cultural framework becomes most clearly illuminated during moments of violence. Just as individual acts of violence and public violent events result from the rising to the surface of latent tensions within the cultural order, so too do scenes of violence in these postwar novels more readily and more clearly reveal the fundamental ideologies that shape the authors' framing of cultural violence. Both texts compartmentalize and attempt to contain white violence, whether, in Tourgée's novel, as a political evil that does not mar social goodness or, in Dixon's, as self-regulation versus selfdegradation. In other words, both novels tacitly or explicitly advocate the use of violence to keep order but only when that violence is limited to the white men who see themselves exclusively as agents of an ideal representative democracy, thus conceptually limiting the right of collective action to white men. 
Tourgée's narrative of unified white manhood is organic, disavowing action in favor of essence, while Dixon's narrative of counter-revolution is constructed along the lines of alternately and complementary latent and patent expressions of white manhood. Tourgée, despite the projected wisdom of his meta-narrator, fails to fully understand structural racism and presents white violence against blacks as a regulating mechanism, the innate response of threatened white manhood that will relax its violence once the threat of black social equality is withdrawn. He sees this disorder as a temporary if undesirable deviation from a color-blind ideal he imagines as the natural, recoverable state of affairs. Dixon, on the other hand, understands the structural fragility of white supremacy all too well, and recognizes that violence is a necessary stabilizing mechanism. Dixon suggests that if the latent, essential whiteness to which Tourgée subscribes is to be maintained, it must be made visible through acts of violence, rituals that at once bind the actors to the fraternity and exclude both non-whites and white dissenters like Tourgée.

Fundamentally, both writers present a cultural order in which white fraternity and white violence are both latent until some external threat necessitates a patent, collective response.

\section{Romancing Race and National Reunion}

Both A Fool's Errand and The Leopard's Spots are racial romances, love stories by white men about the relationships between white men as well as those between white men and the implicitly white nation, written in fairy-tale format with the freedmen replacing the ogre as the principal obstacle to the consummation of democratic wholeness. Both novels depict an implicitly white nation in crisis and Reconstruction, in different degrees of retrospect, as a defining moment for their successive generations. Scott Romine's assertion that " "the genre of prose romance' (among other genres) produces white identity—not as 'racial message' to be 
transmitted, but as a racial fantasy to be played out" is as readily applicable to A Fool's Errand as it is to Dixon's The Leopard's Spots (125). For each novel's white protagonist, the source of crisis is determined by the perplexing presence of black Americans, whether, as in Tourgée's novel, they are to be incorporated into the voting citizenry, or, as in Dixon's, they are to be eliminated from the nation entirely. The stakes for Dixon are more readily visible, as The Leopard's Spots espouses a now-familiar white southern rhetoric of counterrevolution and victory gleaned from defeat in which Dixon characterizes African American political gains as “social rape" (Gunning 7) and Reconstruction "in essence [as] a slave revolt" (Kantrowitz, "One Man's Mob" 67). For Tourgée, the challenge is wrapped up, to borrow from Nina Silber, in "how the northern people interpreted the significance of their triumph and how they came to terms with a victory that necessarily entailed the defeat of fellow Americans" (3). The solution to their respective crises, however, lies not in the fate of black Americans but in the ability of white Americans to collectively agree on the best way to overcome their troublesome presence. This is partially achieved, symbolically, through the trope of cross-sectional romance and the literal marriage of North and South.

Women, black and white, are nearly entirely absent in A Fool's Errand, until Comfort Servosse's own daughter, Lily, steps in near novel's end to dramatize the collapse of the Ku Klux Klan and the subsequent marriage of elite white families and the sectional interests they represent. Southerner Melville Gurney's love for Lily, a carpetbagger's daughter, can never be realized as long as he remains publicly unrepentant for his role in the aborted lynching of her father and Judge Denton. The devoted fathers of both lovers are necessarily opposed to the union when the relationship is first revealed, but each comes to realize he has done the other's child an "injustice" when similarly honorable actions by both parties become known (351). Lily, for her 
part, refused Melville's proposal out of respect for General Gurney, who sent the warning which saved her father's life, and Melville, for his, neglected to alert the other Klan members of Lily's presence, thereby protecting her life as well as her father's. Melville's public repentance, along with Servosse's and Gurney's realization of their mutual misjudgments, ultimately opens the way for Lily and Melville's relationship to proceed, a symbol of healed wounds and political differences reconciled to a common culture. Significantly, Lily and Melville are not married during the course of the novel; it is Servosse's death in the penultimate chapter that brings both young people home to the South and signifies the passing of the old generation in preparation for the new.

Dixon also includes a cross-sectional and politically unifying romance in The Leopard's Spots, and, as in Tourgée's novel, the romance emerges from and overcomes a violent event. Sallie Worth, the daughter of venerable northern politician General Worth, secretly marries her father's political rival, southerner Charlie Gaston, in the prison cell where Gaston is being held on charges of fraud and suspicion of murder in the wake of the "Revolution at Independence" (419). It is Sallie's "great fear" that "she had not responded bravely to this powerful man's singular devotion into which he had poured without reserve his deepest passion," or, in other words, Gaston's sexualized political prowess, that inspires Sallie to defy her father's wishes, and to declare her love across party lines as well as across the Mason-Dixon line (423). That the subsequent public marriage of Gaston and Sallie is to occur on the same day as Gaston's inauguration as governor merges the melodrama of the romance with the political purpose of the novel (461). White supremacy achieves visible solidarity and national reunion by literally crushing the opposition and then celebrating its victory with a cross-sectional wedding. Mason Stokes suggests that "the white nation is a homosocial nation. As long as it's really Charlie and 
General Worth who are married at novel's end — not Charlie and Sallie—-then whiteness can remain pure, since only male-male relations can avoid racial contamination" (154). In this way, the white woman's romantic bond is both subjugated to and in service of political necessity and racial purity.

The outcomes achieved by these comparable scenes of intersectional romance emerging from within the chaos of racial violence, or the ways in which these two authors conceive of national reunion, appear to be fundamentally different. The romance between Lily Servosse and Melville Gurney results in the voluntary dissolution of the Klan, while the double marriage of Sallie Worth and Charlie Gaston results in the political victory of the riotous Red Shirt movement and the ascension of its symbolic leader to the Governor's seat. Yet the crosssectional romances between northern white women and southern white men emerge in both novels as a kind of unifying achievement made possible only by and through the racial triumph of organized white violence. In Tourgée's novel, whiteness overcomes its own demons and rights its own wrongs, thereby reasserting its paternalistic moral superiority, and in Dixon's novel, white supremacy triumphs through sheer show of majority force and the literal extermination of the opposition.

The actual or potential marriages between Sallie and Charlie and between Lily and Melville reflect a trend emerging in popular literature of the 1860s and 1870s in which fictional narratives expressed the newness of the concept of national citizenship. Nowhere was this more apparent than in the "reconciliation romance culture," as Sarah E. Gardner has dubbed it, of novels like John DeForest's Miss Ravenel's Conversion from Secession to Loyalty (1867) and M. A. Avery's The Rebel General's Loyal Bride: A True Picture of Scenes in the Late Civil War (1873) (57). These domestic dramas worked to reenvision the family's relationship to the nation, 
or, in other words, the nation as family. Prior to the war, individuals understood citizenship and the "national family" in terms of a post-Revolutionary rhetoric of parental, generational relationships and inheritance. In the wake of the Civil War, a rhetoric of gendered relations paralleling the national crisis began to emerge in Congressional debate as well as in the conventions of romantic literature. These novelistic romances encouraged change and choice. As Kathleen Diffley observes, "declaring love made characters more malleable than did kinship ties, more likely to preempt loyalties that were already in place, and thus more susceptible to the pull of national citizenship where their parents had privileged states' rights. Instead of confirming Revolutionary inheritance, Romances helped transfer Reconstructive allegiance at the altar of civil responsibilities" (55). In this way the Constitutional Crisis of the late 1860s and 1870s and its literature worked to legally and conceptually limit the newfound freedom of women and of blacks often viewed as wards of the implicitly white male nation by reconceptualizing the national family in terms of romantic love and white male leadership.

In Dixon's novel as in Tourgée's, white women represent the fate of the new nation; in The Leopard's Spots, however, white supremacy has reached a crisis point necessitating the violent regulation of white women's “choices". ${ }^{13}$ Tom Camp's daughter Annie will be married to a white man of her own lower class and then immediately murdered by her father and husband when a gang of would-be black rapists threatens the burgeoning civilization represented by the exchange of her loyalties. The hail of bullets amid "a wild scramble" conveniently absolves any one man of her killing while simultaneously crediting Tom Camp, Hose Norman, and the other white men present with "sav[ing] her from them brutes" (127). "Annie's martyrdom, which precipitates a rebirth of the Ku Klux Klan," Stokes argues, "becomes the excuse for a new wave of white terrorism of blacks, and the clear signal to white women is that they must fear not only 
the potential black rapist but the white mob that may find it necessary to sacrifice them in the name of racial purity" (144). Clearly Helen Lowell, daughter of "The Honourable [sic] Everett Lowell" (389), Northern orator and supporter of Negro rights, is meant to learn this violent lesson when the mulatto George Harris, Lowell's protégé, declares his love for Helen and is brutally rebuked by his mentor (394). Other women in the novel—Charlie's mother, Mrs. Gaston, and Tom Camp's second murdered daughter, Flora-find themselves victims as well, of black men if not of white.

The sheer volume of dead and otherwise victimized women in Dixon's The Leopard's Spots indicates that even if white women could generally be counted on to make the "right" choices and uphold the racial purity of the new nation, others, particularly black men and Radical Republicans, could never be trusted to respect their decisions or the social and sexual boundaries presumably established as a result. Therefore, the fragility of feminine choice and the ostensibly inherent vulnerability of white women as primary guardians of sex and the national family point to the "necessity" of violence, or the masculine management of the instabilities of the norm. Sallie Worth's independent, in fact defiant, choice of Charlie Gaston and the racial politics he epitomizes serves to obscure and somehow rectify these earlier conflicts in which white women present challenges to racial (and thus national) purity, and inevitably meet a violent and untimely death.

In Tourgée's novel, however, the racial dynamic of sexual violence is reversed. Black victims of white rape represent the specter of miscegenation and the threat to racial purity that is eventually superseded by Lily’s relationship with Gurney. One of the few women present in the text is Bob Martin's unnamed wife, representative of black feminine loyalty to her race, the devoted wife who prepares dinner for her husband, cleans up after the meal, and puts the children 
to bed (186). Her marriage to Martin, an independent black artisan, is the perfect model for the conceptual separation of public and private spheres until the Martins' home is raided and Martin's wife and oldest daughter are brutally raped by members of the Ku Klux Klan. Martin is tied to a tree and forced to watch as the two women, who are never given names, are violated in a ritual that is clearly engineered to terrorize him (187). Upon hearing Martin's tale, the Fool is overcome with "amazement, pity, and shame," at least in part because the behavior of these white male rapists reflects badly upon all white men and corrupts the potential for the productive maintenance of separate spheres (188). Mrs. Martin's rape is representative of what happens when the public bleeds into the private, and in this case, white men violently transgress this potentially stable boundary. Like Tom Camp's murdered daughters, Martin's wife is less a character in her own right than a symbol of a certain kind of white fraternal future, which, for Tourgée is tainted by the Klan's distasteful methods.

These victimized and therefore compromised women, black and white, are part and parcel of the racial fantasies that Tourgée and Dixon play out during the course of the novels. Dixon's pure white women who are either killed or raped by black "brutes" serve to further overtly white supremacist arguments that refused to address the legal rights of freedmen and women in any sphere, public or private. Despite Tourgée's fiery rhetoric on behalf of African American legal and civil rights, his Fool continues to believe, if implicitly, that "the world could be divided into a public sphere of justice and equality and an associational private sphere that allowed discrimination. These two separate spheres were explicitly gendered and considered complementary: the public world of commerce and politics belonged to men, whereas to women was left the home and its occupants" (Dailey 89). The Martin family appears to be fantastic evidence of this parallel social structure in action, until the fragile equilibrium of this tacit 
agreement between blacks and white Republicans is disrupted by white supremacist violence. Liberal ideology and adherence to the separate spheres doctrine allowed white "radicals" like Tourgée to champion black political rights while at the same time limiting social intercourse between the races. More conservative whites argued that this separation was impossible to maintain, rhetorically equating "black suffrage and interracial sex" (Dailey 96). The separate spheres doctrine, however, by design did not sufficiently erode white manhood privilege nor challenge the supremacy of white men. Instead, it reaffirmed white men's self-appointed responsibility in conferring and limiting the citizenship privileges of black men, at the same time maintaining the rhetorical and physical separation of black men and white women.

In constructing fictional romances of reunion that displace white and black women and replace them with white male representatives of sectional politics, Tourgée and Dixon are reacting to and drawing on a crisis of white manhood fraternity that peaked during the fratricidal Civil War. In National Manhood: Capitalist Citizenship and the Imagined Fraternity of White Men, Dana D. Nelson establishes abstract white manhood as the cultural and political framework for civic engagement from the post-Revolutionary period onward: "It worked symbolically and legally to bring men together in an abstract but increasingly functional community that diverted their attention from differences between them — differences that had come alarmingly into focus in the post-Revolutionary era" (6). Whereas in the early years of the nation this imagined fraternity helped diverse groups of men to envision themselves as a new, coherent nation with like goals and interests, these differences between men were again exaggerated in the Civil War and post-war periods, this time by the intensity of intra-national battle - "fratricide," as Steven Weisenburger has called it (184). The ensuing sociopolitical chaos of the Reconstruction period agitated desires not only for structural unification but for the immediate conceptual erasure of the 
internal differences between men that led to the disunion of Civil War in the first place. "Among veterans on both sides," Blight observes, "a 'culture of character' emerged as a core ideology. Old soldiers tended to measure each other as preservers of an older, more wholesome society, one uncorrupted by materialism" (201). Intersectional shared nostalgia for the imagined and inherited fraternity of white men in the post-Revolutionary period provided a rallying point and a ready, if complex, precedent for the potential abatement of the lingering embarrassment and uncertainty of fraternal civil conflict.

Uncertainty was paramount during the war, particularly in terms of the inability of authors and historians to fully determine the causes and the effects of the Civil War. Historian Thomas J. Pressly observes that differences in attitudes about the war and specific responses to the war were generally more significant between generations than within, relative to differences in political and moral perspectives. Pressly also suggests that many of the "primitives," those who had experienced the onset and the war itself firsthand like Horace Greeley or E. A. Pollard, and who would, as a result, have had little distance from the war in their evaluation of its causes, "tended to explain the coming of war in terms of the actions of evil individuals motivated by personal ambition and greed, and frequently they pictured a small group of men banded in a conspiracy. They often emphasized a single cause for the war-personal ambition, the institution of slavery, section aggression, or some other one factor" (Pressly 145). In displacing responsibility for the war onto a particular and isolated institution or seditious group rather than on expanding fissures in dominant underlying ideologies, interpreters of this generation effected a bipartisan and cross-sectional internalization of an imagined national (white male) fraternity. While not necessarily in agreement about exactly who was responsible, a general consensus that the cause was isolatable and external indicates an early and pervasive belief (or desire to believe) 
that the war was not the consequence of a rupture between democratic structure and ideals but rather the result of an external and excisable evil.

Historians writing in the late 1880s and 1890s, like James Ford Rhodes, Frederick Jackson Turner, Woodrow Wilson, and Edward Channing, told a somewhat more complex story, "singl[ing] out, as the forces which had ultimately produced sectional hostility, not ambitious and wicked politicians, but the spread of cotton cultivation, or the influence of physiographic and economic factors" and, most significantly, the institution of slavery (Pressly 222-223). From this later generation, many of whom were alive during and even fought in the Civil War, emerged a "nationalist tradition" in which are counted historians for whom the preservation of the Union was paramount and for whom the Civil War had produced positive results because it "had destroyed the institution of slavery and had preserved and strengthened the American nation" (Pressly 223). However, both the abolition of slavery and the formal perpetuation of national unity following Northern victory had unexpected and contradictory results. According to George M. Fredrickson, "the war was a triumph for conservative nationalism, not for the utopian view of American society for which some abolitionists thought they were fighting" (Inner Civil War 188). In other words, the preservation of the Union was not a direct result of the abolition of slavery, or vice versa, and the abolition of slavery did not amount to a shared belief in or national dedication to a greater humanistic vision of equality.

The structure, the shell, of the Union remained intact while its stated democratic ideals continued to take substantial hits: "it was apparent in the years that followed [the Civil War] that the drive for radical reform had lost momentum. The fact was that the nation had turned a corner; the triumph of Unionism and nationalism had led to assumptions that obviated the antiinstitutional philosophy that had been the basis of abolitionism. It had turned the genuine 
radicalism of the prewar period into an obvious anachronism" (Fredrickson 188). With the Civil War physically over and the slaves formally emancipated, continued agitation on the part of human and civil rights activists was at odds with emerging ideas of nationalism in that any continuing challenges to the structure of the reformed Union contested the unequivocal success of the North's reunifying victory. As in the post-Revolutionary period, internal differences among citizens became amplified, and at the same time contained, within conceptual desires to (re)claim national wholeness. "Rooted in this ideology of manliness and an antimodern scorn for commerce and materialism, which many veterans ironically felt deeply ambivalent about," Blight suggests, “the soldiers' reunion, both metaphorically and in reality, had become by the 1890s the dominant mode of Civil War memory" (209).

Ideas about the causes of the war would evolve over time, and reflections concerning the outcome and the meaning of the war necessarily occurred in retrospect, with implications read backward onto the pre-war and wartime periods. "Our Civil War," Timothy Sweet observes, "is often said to have been fought entirely by 'Americans,' entirely on the soil of the 'United States.' But this conventional description of the war was itself one of the representational questions at issue - for it is only possible to say in retrospect that the Confederates were rebellious 'Americans' because the Northern states won the war" (2). The concerns of influential Civil War critics Edmund Wilson and Daniel Aaron with the "unwritten war" and the absence of "an American masterpiece" (Aaron xv) would have been quite different if the South had been successful in leaving the Union. Wilson, in fact, emphasizes national disunion at the time of Southern secession: "The slave-owning Southern states and the rapidly industrializing North had by this time become so distinct from one another that they were virtually two different nations; they were as much two contending power units - each of which was trying to expand at the 
other's expense - as any two European countries" (xv). In hindsight, it seems absurd to wonder why canonical authors like those treated by Aaron and Wilson-Hawthorne, Melville, Emerson, Whitman, James, Howells, Cable - were unable to effect national unity through epic literature at a time when the nation was thus fractured into virtually two nations.

Late nineteenth and early twentieth-century Americans embraced "narratives of reconciliation, stories of healing," like those penned by Tourgée and Dixon, because, Jennifer C. James asserts, they "enable[d] an endless deferral of a more painful engagement of history, one that necessarily would grapple with two defining and persistent facts of U. S. existence: its tactical reliance on violence for the development of the state and on the willful subjection of African Americans for its economic benefit" (58). Economic and political opportunities extended to black men during Reconstruction were the insincere gestures of a national white citizenry professing democratic "wholeness" while at the same time protecting their exclusivity by brutally reprimanding genuine attempts by black men to take advantage of and engage with the opportunities newly available to them. As historian Philip Dray observes, it was in the Reconstruction "era that black aspirations for economic independence and citizenship were both nurtured and thwarted, white resistance to the strivings of freed blacks began to assert itself, and a pattern of deadly violence as a means of repression emerged" (32). Lynching and ritualized racial violence served not only to "punish" implicitly guilty blacks but, more importantly, to provide a platform by which to reaffirm the "naturally democratic" impulses of white men of both sections while preserving a national structure of white supremacy. 


\section{Ideologies of White Fraternity and Regenerative Violence}

Tourgée's narrative assumes a homogenous and moral white unity that transcends temporal boundaries and works to negotiate apparently temporary inconsistencies within this organic fraternal bond. Dixon exploits these same contradictions to his political advantage. The very basis of Dixon's popularity as an author, as Brundage, Romine, and others explain, is located in his knack for constructing stability out of instability, for enacting a collective and unified whiteness in his fiction, which he does most aggressively (and is perversely most successful) through depictions of white violence against blacks. As Romine observes, to "recognize that whiteness is both the traumatized object of melodrama and the heroic agent of epic adventure - that The Leopard's Spots is both historical narrative and utopian fantasy —is to recognize that whiteness does not make sense" (125-126). "Dixon's pernicious genius," Romine concludes, "was to offer a compelling scenario of white identity — compelling not in spite of, but because of the unfixed, unstable identities he produces" (145). White anxieties over unstable white identities, which Trudier Harris, Stokes, and others have located at the root of ritualized racial violence and performed dehumanization, work for Dixon rather than against him. In The Leopard's Spots, as in A Fool's Errand, white manhood, unlike blackness or womanhood, can be redefined, recoded, and reborn through regenerative collective action.

Both novels mobilize this trope of regenerative violence via lynching scenes in which the white male protagonists stand up to other white men, but their reasons for opposing the lynching in the first place vary. In Dixon's novel, Flora, Tom Camp's second daughter to die over the course of the novel, is seen "talkin' with that nigger," and two days later she goes missing (369). A mob of "a thousand white people" operating under the guise of a search party is formed "within a half-hour" of the alarm, and the little girl's body is found early the next morning with 
"her clothes torn to shreds and stained with blood" and "a wound where her skull had been crushed" (375). The sexual nature of the crime is immediately clear to the searchers as well as to Flora's father, and another search party is formed, this time with "no women and children among them, only grim-visaged, silent men and a pair of little mild-eyed, sharp-nosed bloodhounds" (376). When the searchers return, "a grim, swaying voiceless mob with one black figure amid them," it is Charlie Gaston who "rushe[s] forward to prevent a lynching" (381). Gaston has already decided on this course of action when he recognizes the intended victim as his childhood playmate, Dick. Despite Gaston's pleas for a "fair trial," the crowd takes Dick down to the spring where Flora was apparently assaulted, douses him in oil and lights him on fire (383-384). Afterward, "ponder[ing] over the tragic events of that lynching," Gaston concludes that "such crimes as Dick had committed" were nonexistent during slavery but "had increased with alarming rapidity" under the regime of white scalawag Allan McLeod (385). Gaston seems to recognize that the lynching ritual displaces true republican practice, but he is more concerned with blaming McLeod and other white liberals for creating a social structure in which black men possess the combined need and opportunity to rape white women.

Unlike Gaston, who is physically present at the lynching, Tourgée's Comfort Servosse must experience secondhand the details of the lynching of Jerry Hunt, the novel's prototypical wise and politically-savvy black man, with whom Servosse is personally friendly (311). Young Ralph Kirkwood is the first to give himself up after the foiled attempt on the lives of Servosse and Denton and John Burleson's subsequent public defection from the Klan. Upon tendering his confession, Kirkwood tells a terrible tale of Hunt's murder, in which Klan members enter Hunt's home in the middle of the night to find "Uncle Jerry, laying there on the bed, sleeping as quiet and peaceful as a child. We waked him up, took the bed-cord out of the bed, and tied him on the 
horse next to the one I rode. . . . He was praying all the way in, and never offered any resistance at all" (314). Kirkwood recalls "feeling mighty bad all the way" before he tells of seeing "the face of Uncle Jerry as he hung there on the limb" illuminated by the light of a match (314). Where Gaston assumes that Dick is guilty of raping Flora Camp, Servosse assumes that Hunt is innocent of any wrongdoing. In fact, the crime with which Hunt is charged is never explicitly stated; the only vague suggestion of any crime is Kirkwood's recollection of "a decree from the Rockford Camp to visit the extreme penalty (that meant kill, always) on Jerry Hunt" (313). In Tourgée's novel, the system seems to be working properly, as at least one lynching is prevented and the would-be lynchers are apparently made to answer for their crimes.

Tourgée detests the violence of the Klan, regardless of its motivations, and emphasizes his stance by constructing a lynching scene, the revelation of which leads directly to the dissolution of the Klan. The suggestion of rape, always present in Dixon's novels, does not have a place in this scene from A Fool's Errand. In fact, the intimate horror of the lynching and its confession, the evident contradictions in Kirkwood's familiar references to "Uncle Jerry" even as he admits his role in Hunt's murder, and Servosse's personal connection to the victim are secondary to the very fact of Kirkwood's confession and its role in the collapse of the local Klan as a unit. Gaston also expresses disapproval of the Klan's actions, but his dissatisfaction is less with the Klan itself than with the improper use of its power in the ritual burning of his childhood friend. The relationship between Dick and Gaston is a detail important in itself as it establishes Gaston's human desire to befriend blacks only to have his kindness betrayed. Because of Servosse's dedication and success in bringing down the organization itself, in destroying its perceptible structure, he appears also to disapprove of the Klan's underlying ideology of white 
supremacy. However, Tourgée, like Dixon, is actually separating the visible violence of the Klan from the idealized white male fraternity it purports to serve.

For Tourgée, open renunciation of the Klan and its violence by its membership amounts to the collapse of the underlying principles behind its formation. Tourgée's meta-narrator, who is purportedly wiser than the Fool whose story he tells, describes Judge Denton's act of "taking the confessions of hundreds whose awakened fears laid bare the hidden mechanism of thousands of acts of violence," yet he does not seem to grasp the irony in his own use of "hidden mechanism" to describe an organization that nearly all of the local white men (and therefore all the men in positions of power), save Servosse and his immediate company, seem to have known all about (316). That so many would make similar confessions belies the existence of a secret to be revealed in the first place, and the en masse and orderly method of submission points to the likelihood of conspiracy among the men to regulate the disclosures as well as to the disingenuity of the confessions themselves.

None of the men charged are jailed, but rather are held in the "custody" of some friendly private citizen, which indicates that the guilty had little to fear in the way of legal repercussions, regardless of the atrocities they might admit (315). This is confirmed in the wholesale pardoning enacted by "the Legislatures of the several states" which "immediately passed an act of amnesty and pardon for all who had committed acts of violence in disguise, or at the instigation of any secret organization" (317). Tourgée notes that the pardons were even extended to the victims, as well as to members of other societies, like the Union League, which "were not known to have counseled any unlawful acts" in the interest of presenting an image of uniform justice (317-318). Here Tourgée's narrator registers some little sarcasm in the implication that the victims need to be pardoned for the offense of being black. The blanket conferring of amnesty, as Tourgée no 
doubt suggests, unfairly indicts blacks as well as whites, along with radicals and conservatives alike, for the chaotic state of the Reconstruction South. In this case, society's sympathy for its white brethren is reflected in the legal pardoning of its most prominent criminals.

As much about recovering an ideal, organic white manhood as it is about advocating for black rights, Tourgée's autobiographical novel insists on a "color-blind" politics that fails to account for the historical advantages of white manhood at the same time as it promotes incongruent distinctions between the social and political beliefs and behaviors of white men. Servosse, self-proclaimed advocate for black political equality and fairness under the law, is prepared to openly condemn white Southerners for their despicable racial politics and overt acts of racial violence but finds them to be "good Southern gentlemen," and honorable, nonetheless. Like the legislators with whom he is not entirely satisfied, Servosse rationalizes the behavior of the white supremacist Southerners. Implicitly, he also excuses intimidation and threats as means of depriving freedmen of their rights, only asserting strenuous objections to the "actual violence" which he imagines "was not at first intended" (324).

More surprisingly, though, Tourgée's meta-narrator also celebrates “the indomitable spirit of this people" and not only accepts but romanticizes the rhetoric of counterrevolution and the Noble South (322). Furthermore, Servosse exalts Southern "bravery" in racial terms, declaring that "only a race of warlike instincts and regal pride could have conceived or executed" a counterrevolution "while thus bowing beneath the scourge of shame, [of] early apprehending the weak point in their enemy's coat of mail, and steadily addressing themselves to planting therein a fatal stroke" (323). In this way, Tourgée constructs a rhetoric, under the guise of radicalism, that condones Southern retaliatory violence and places it within the realm of legally sanctioned behavior, particularly because it works stealthily from within the system, ostensibly 
preserving the new Union at the same time it challenges the Union's avowed principles and codified laws. His narrative becomes one of noble conflict, with whites on either side of the internal revolutionary divide virtuously defending their respective beliefs and, as Tourgée would have us believe, mutually respecting each other's courage and determination. This, Tourgée seems to say, is American democracy in action. This particular approach to "democracy" requires an ongoing civil war of masculine character in which white men must continually assert their democratic impulses via mutually reinforced violent resistance to the "tyranny" of others. In Tourgée's novel, democracy for white men is enacted at the expense of African American legal and civil rights. Despite the depths of degradation to which they have sunk, white men can be redeemed, pardoned, rehabilitated, and returned to responsible citizenship, but black men are still victims, still subjugated, still powerless.

Tourgée's depictions of Klan violence and legal repercussions in A Fool's Errand anticipate his later arguments on behalf of Homer Plessy and illustrate some of the more glaring inconsistencies in his signature doctrine. Bill Hardwig observes that "Tourgée's view of Reconstruction politics seems to be idealistic, depending upon a 'color-blind' justice system in which 'right reason' will prevail over racist sentiment," a view which neglects to consider the deeply structural nature of white supremacy at the same time as it distinguishes between the supposedly rational nature of justice and the sentimental or irrational nature of racism (5). In terms of Tourgée's argument of the Plessy case and its ultimate outcome, Hardwig notes that while "Tourgée relies on the indeterminability of race and believes right reason will reward his argument, he does not account for or counteract the prevailing sentiment within the white community about absolute racial difference" (10). As with the Plessy case, Tourgée's argument in A Fool's Errand turns on the goodwill of the white community and is hampered by his 
inability to see the paradox of placing his hope of justice for the freedmen in the hands of white men, Klan members and more liberal prominent white citizens. This is painfully evident in the Tourgée's wholesale forgiveness of the "better class" of Southerners once they confess and apologize for their Klan involvement, regardless of the crimes in which they took part.

The same Klan that spontaneously dissolves in A Fool's Errand develops just as spontaneously in The Leopard's Spots as the decisive symbol of active, unified white manhood. Its first appearance is in response to black school commissioner Tim Shelby's attempt to kiss a young white schoolteacher, Miss Mollie Graham (151). There is no pretext of organization, simply the appearance of "two hundred white-robed horses assembled around the old home of Mrs. Gaston, where Tim was sleeping” (151). Shelby is lynched, over the course of two brief but brutal paragraphs, by the "Law and Order League, which sprung up like magic in a night and nullified the programme [sic] of Congress ... a spontaneous and resistless racial uprising of clansmen of highland origin living among the Appalachian Mountains and foothills of the South" (151). The narrative spontaneity of the Klan's birth indicates the inherent, if dormant, visceral unity of white supremacy. However dissimilar Tourgée's rebuke of Klan violence might appear to Dixon's celebration of the Klan as the "Law and Order League," the two novels are doing something very similar in their attempts to contain the visible, active manifestation of white supremacy in order to restore the ostensibly peaceful and orderly white fraternity underneath.

Where Tourgée accepts white fraternity as a given and explains away its functional inconsistencies as exceptional, Dixon's The Leopard's Spots turns on the action of white unity and the solidification of racial difference along the lines of what Mark M. Smith has termed "the historically conditioned, visceral, emotional aspect of racial construction and racism" (4). Smith demonstrates shifts in racial identification, beginning at least in the 1850 s but becoming 
especially pronounced after the Civil War, which he describes as "sensory racial stereotypes," neither rational nor irrational but felt, and therefore virtually immune to evidentiary dispute (5). In the wake of Emancipation and the resultant changes in dominant structures governing interaction between the races, this perceived ability to sense racial difference served as the basis for self-identification with a specific racial group, particularly for "whites [who] derived their authority by defining when and where sensory intimacy was permitted" (Smith 50). If this sensory self-identification, this visceral racialization, is the thing that Tourgée is unable to fully recognize, rationalize, or explain away, it is also a structural inconsistency which Dixon is able to parlay into the consolidation of white masculinity across class lines. More aggressively blurring the social and the political, Dixon self-consciously defends the perceived right of white men to regulate sensory intimacy and social relations between the races as well as between the sexes. Building on long cherished cultural assumptions and those earlier advanced in Tourgée's novel, "Dixon offers whiteness not as essence, but as action; not as purity, but as purification; not as fact, but as affect; not as noun, but as imperative verb - more precisely, he stages and restages a compelling drama between the latter, dynamic terms, and the former, static ones" (Romine 126). These static terms, accepted by Tourgée and other radical whites of his generation, despite their fervent resistance to the dynamic elements of white supremacy later championed by Dixon, essentially translate into and provide the substance for Dixon's racist rhetoric.

Notwithstanding their lack of organized action prior to the spontaneous appearance of the Klan, white men have hitherto been aware of their own whiteness, Dixon suggests, particularly by their ability to perceive blackness in others "by smelling, touching, listening, and tasting, as well as by looking" (Smith 4). Tom Camp, disabled confederate veteran and poor white integrity 
personified, is able to smell blackness: "At night when they'd detail me to help the ambulance corps carry off the dead and wounded, there was a strange smell on the field that came from the blood and night damp and burnt powder. It always smelled like a nigger to me" (29). This visceral ability to sense blackness, even when that blackness is not visible, is as natural to Camp as is his own physiological makeup: “I hate 'em. I can't help it any more than I can the colour [sic] of my skin or my hair" (29). Here Camp attests to the invisibility of whiteness as well as of blackness. While his skin and hair are visible markers of his race, they are, more than determining, the outward expression of his internal whiteness, which is established by his feeling white - his hatred of blacks — and his heightened sensory abilities, his aptitude for sensing blackness in others. Dixon assures his audience that even more than visible whiteness, these are the qualities that unite white men prior to their enactment of this previously latent commonality.

Dixon suggests that the sort of organic whiteness to which Tourgée subscribes is not only possible but unavoidably biologically ingrained. Therefore, while whiteness and its attendant claim to privilege cannot be accidentally lost or forcibly taken, and thus neither falsely replicated, one can actively deny or passively neglect one's own whiteness. Accordingly, white manhood is exclusively political and requires concerted action in service of the counterrevolution and solution to "the race problem." Romine observes that "white manhood is thus posited as dormant prior to the 'Negro Uprising' (100), just as it acquires a contingent dimension afterward - that is to say, not all men socially recognized as white will fulfill the imperatives of white manhood" (128). The "Negro Uprising" in The Leopard's Spots is defined as "riot at Washington," brought on by the combined terror of a "group of oath-bound secret societies, The Union League, The Heroes of America and The Red Strings dominating society, and marauding bands of Negroes armed to the teeth terrorising [sic] the country, stealing, burning and 
murdering" (101). The declaration of a common political enemy, the mixed race Republican Congress of Radical Reconstruction, sets the stage for the unification of white manhood in common resistance, and thus virtuous whites in both sections of the country are reconceived as allies: "The abolitionists of the North, whose conscience was the fire that kindled the Civil War, rose in solemn protest against this insanity. Their protest was drowned by the roar of multitudes maddened by demagogues who were preparing for a political campaign" (102). Here Dixon also emphasizes that this is a new conflict, not a continuation of the old, as both Southern secessionists and Northern abolitionists are now purportedly of the same mind.

The Klan, as it forms in response to the violation of white women by black men (social rape), is enhanced by its purpose as well as by its impulsiveness, as it is the supposedly spontaneous and collective expression of white feeling. The logistical organization of the Klan is, like the internal mark of whiteness, unseen, and, by its invisibility, it transcends the rational, thereby providing an unanswerable claim to legitimacy: “This Invisible Empire of White Robed Anglo-Saxon Knights was simply the old answer of organized manhood to organized crime. Its purpose was to bring order out of chaos, protect the weak and defenseless, the widows and orphans of brave men who had died for their country" (152). When the Klan parades through the streets of Hambright, its organization is an open secret: "How the news was circulated, nobody knew, but it seemed everybody in the county knew of it” (153). As Susan Gillman observes, "while conjuring so much overwhelming evidence to the contrary, Dixon continually reenacts a white unity that proclaims itself as unseen, whether in the form of the Invisible Empire of the Klan, America's empire overseas, or a united body politic at home" (108). The Klan in particular is hyper-organized and widespread, held together by active loyalty to white supremacy as well as by fear of consequences for deserters: "It was impossible for them to secure evidence against any 
member of the Klan unless by the intimidation of some coward who could be made to confess. Not a disguise had ever been penetrated" (156). Whiteness goes to great lengths to ensure its invisibility while, at the same time, making itself as visible as possible in order to provoke the greatest potential terror and to establish its popular authority.

This earlier, invisible Klan is popularly sanctioned and effects "a sense of grateful security" (154) in the dominant white citizenry, as the "violat[ion] for a moment [of] a statutory law" in support of "a higher law" (163). That moment has purportedly come and gone by the time a new Klan led by members of a younger generation, scalawag Allan McLeod and Hose Norman, momentary husband of the tragically murdered Annie Camp, surfaces in the chapter entitled "The Danger of Playing with Fire." Unlike their noble predecessors, this young Klan is identified as a "crowd of desperadoes" (169). McLeod and Norman are overheard during their meeting in the woods by “one of General Worth's Negroes" (168), and Reverend Durham, upon hearing the news, tells young Charlie that “there's a lot of drunken devils, masquerading as Ku Klux, going to kill a man to-night. If we can’t reach Major Dameron's in time for him to get a lot of men and stop them there'll be a terrible tragedy" (169). This new imposter Klan is operating outside of the "war" of Reconstruction in which its earlier incarnation "fought," and it is now, come Redemption, fundamentally a terrorist group disobeying and dishonoring its parent organization through the use of reckless and gratuitous force (163). Especially telling is McLeod's participation in the Klan, as he later becomes leader of the Republican party and Gaston's chief antagonist in the novel (258).

This new imposter Klan is unexpectedly similar to the disbanded Klan of Tourgée's $A$ Fool's Errand in that it is identified as separate from the underlying ideology it proposes to enforce and somehow represents a misunderstanding, a misinterpretation, of white fraternity. 
Romine notes that "Dixon insists here ... that the Klan be disbanded precisely because of its natural tendencies toward chaotic, unauthorized violence . . . the Klan can save civilization, but it can never be civilization itself' (133). In order to reaffirm the legitimacy of the earlier active Klan, as well as of its continued latent existence, Dixon must create a rogue faction and set the "real" Ku Klux as its opposition, still in defense of a "higher law." In order to retain its popular sanction, Klan violence must always be noticeably responsive to a more violent, more devastating black threat. Any violations of law must be momentary, temporary, lasting only until the perceived wrongs are legally and politically "righted."

Both Tourgée and Dixon draw on the history of the Klan in order to formulate their fictional accounts. The Ku Klux Klan, the ultimate symbol of masculine violence, was initially formed in December of 1865 by six young men who were reportedly more interested in irresponsible self-amusement than overt terror. ${ }^{14}$ Tourgée, in ancillary material attached to some editions of his novel, affirms the assertion that the Klan began as a "huge joke which certain pretended ghostly night-riders were playing upon the ignorant freedmen of the South, making them believe that they were the spirits of slain Confederates hailing from hell and slain in some great battle, which was almost always Shiloh" (Invisible Empire 397). While Tourgée dates these images to initial print accounts of Klan activity in 1868, the implication persists that the Klan initially developed from a series of immature pranks, finally becoming solidified as a terrorist organization in April of 1867 with a meeting of representatives in Nashville, Tennessee, where a constitution was drawn up and Confederate General Nathan Bedford Forrest was elected the first Grand Wizard (Chalmers 9). ${ }^{15}$ White southerners quickly capitalized on the regalia and ritual portended by the antics of the early Klan and its purportedly benign beginnings and instigated a widespread campaign of terror and social control shrouded in the trappings of a masculine 
fraternal order. That many historians consistently minimize the activities of those first six Klansmen in Pulaski, Tennessee, as poorly conceived youthful mischief rather than predatory cruelty, exemplifies the ingrained cultural sense of white superiority, white privilege, and white fraternity of which the Ku Klux Klan is symptomatic.

In both novels the shadow society of the Ku Klux Klan and its racially motivated violence are the external symbols of internal fractures in the structure of national democracy. For Tourgée, the violent actions of the Klan represent a challenge to his white liberal idealism. The terrorist activities of the Klan minimize the import of the North's victory and disrupt Tourgée's conception of unity among white men of both sections as a pre-existing and thus recoverable abstraction. Therefore, the narrative dissolution of the Klan in A Fool's Errand represents a white liberal understanding of white men as model citizens while minimizing the culturally splintering effects of the Civil War. Where Tourgée insists on the rallying possibilities inherent in the North's victory and the attendant preservation of the Union despite the disappointment of Reconstruction, Dixon relies on the presence of the Klan to restage the war in terms of the North's ultimate failure. Dixon emphasizes the social necessity of the Klan and underscores the urgency behind its formation in order to exploit the structural weaknesses in the North's Reconstruction program and to propose an alternative scenario in which the conflict is not sectional but racial. Dixon's counter-revolution pits "virtuous" whites of both sections against "evil individuals" involved in a "conspiracy" to displace the white race in favor of the black. In both novels, however, white men emerge as the consummate protectors and representatives of American "democracy," and postwar extralegal white violence against blacks is effectively contained. 
That it expressly argues for the expansion of black civil and legal rights and that it was a championed Reconstruction novel of liberal white northerners makes Tourgée's A Fool's Errand an especially apt as well as an especially disturbing example of incoherent social structures operating under the guise of ideal democracy. Tourgée's portrayal of the Reconstruction-era $\mathrm{Ku}$ Klux Klan is ostensibly a critical one in which he decries the Klan's ritualized racial violence and organized subversion of Reconstruction laws, indeed provoking harsh rebuttal from conservative contemporaries who would characterize Tourgée's novel as "a wilful [sic], deliberate, and malicious libel upon a noble and generous people" (Royall 3). Tourgée attempts to emphasize the political objectivity and benevolent intent of his novel by connecting $A$ Fool's Errand to direct social commentary in The Invisible Empire, a 136-page addendum to the novel explaining Tourgée's methodology, expounding on his research, and including eyewitness testimony, excerpts from the Klan's "Prescript" or constitution, and the text of Congressional reports. Tourgée's attempt to provide detached historical and legal background in The Invisible Empire both highlights his good intentions in documenting and exposing a social evil and undermines his stated goals. In focusing his critique nearly exclusively on the Ku Klux Klan as an organization, Tourgée presents a clear, identifiable, and isolatable problem, a white racist presence, which veils the realities of systemic racial domination.

Tourgée's neo-abolitionist rendering of the Klan purports to be self-conscious in its metanarrative disparaging of "the Fool's" naïveté because the Fool underestimates the South's devotion to antebellum social practices and because he misreads the apparent altruism of the Northern politicians in whom he places his faith. In short, he is a fool because he believes in the potential success of the project of Reconstruction, if only the two disparate (white) factions can find some space of agreement. What the meta-narrator seems to know and that the Fool doesn't 
is that Reconstruction is doomed because the politicians of the North are tired of a fight they were never fully invested in and because the greater South steadfastly refuses to give the freedmen "a white man's chance." However, even the narrator does not recognize that the Fool underestimates or misunderstands the depth and breadth of white manhood fraternity as a political system. Far from it, Tourgée's protagonist and meta-narrator both assume a homogenous and recoverable white unity that has been temporarily disrupted by the now-defunct institution of slavery, the ensuing conflict of Reconstruction, and overt acts of white racism like those perpetrated by the Ku Klux Klan. The problem for Tourgée, then, is not exactly the incorporation of the freedmen into the voting populace, as he would like to suggest; instead the problem is the inability of imagined white unity to function as such. The genuine extension of civil and legal rights to the freedmen is simply, for Tourgée, a necessary result of the functional recovery of an organic white fraternity. It is, therefore, Servosse's sincere belief in a homogenous and natural white unity that ultimately makes him a fool.

\section{Citizen Soldiers and the New Nation}

Localized expressions of white "revolutionary" violence erupted in response to African American assertions of personhood and claims to citizenship in the postwar period. Often interpreted by participants, by historians, and by amateur social theorists like Tourgée and Dixon in terms of localized expressions of democratic dissensus, a natural civic response to, or check on, a centralized national government, these eruptions indicated rather a continuation of underlying conflicts which had not been settled by the Civil War. Nelson traces an insistence on the practice of local democracy to the post-Revolutionary period in which "face-to-face democracy, [sic] was amplified in the increasing phenomenon of the extragovernmental 
organization of people, in county assemblies, watchdog committees, radical associations, and out-of-door actions. A clear spillover from Revolutionary practice, these groups, commonly remembered in the dystopic rhetoric of vigilantism, riot, and mob, were present in every major city and across the countryside" (32). In the postbellum period, a more romantic and nostalgic view of extralegal organizations emerged and became solidified in the context of fratricidal Civil War and pursuant attempts to reclaim a very real, if fundamentally abstracted, national subscription to an imagined white manhood fraternity. As Kantrowitz observes, in "that lost antebellum world," prior to the Civil War, "armed collective action, with or without formal legal sanction, had been a crucial aspect of white men's responsibilities as citizens. When confronted with a danger of sufficient seriousness, a true citizenry would arise spontaneously” (“One Man’s Mob" 67-68). The behavior of the white mob was perceived as both a democratic right and a sacred responsibility, in direct contrast to the riotous image of the African American soldier.

Dixon's combined rewriting of the 1876 Hamburg, South Carolina, and 1898 Wilmington, North Carolina, massacres, cooperatively identified in The Leopard's Spots as "Revolution at Independence," is gathered around the image of organized-yet-riotous black troops, who demonstrate a purportedly dystopic counterpoint to the orderly and normative armed collective action of white men (419). The Independence riot begins when "a Negro trooper passing along the street refuse[s] to give an inch of the sidewalk to a young lady and her escort who met him." The white man "knocked him down instantly and beat him to death" which, in turn, aroused the "wildest passions of the Negro regiment." Later that night, "a mob of five hundred Negroes attempted to force their way into the hotel" where Gaston, upon whom McLeod has placed the blame for the soldier's death, is staying (414). This riot contains rather standard elements of white supremacist depictions of Reconstruction and post-Reconstruction era 
race riots. First, generally obstinate and aggressive "negroes" are engaged in some sort of bad behavior, whether the refusal to yield sidewalk space to whites, as in Hamburg, or the embrasure of the free press, as in Wilmington. The pattern dictates that there must be a black mob enraged by animalistic passion and a trigger-happy desire to possess and use firearms against whites; a specific threat to pure white womanhood, either in the form of physical assault or slander; and corrupt and ineffectual white political enemies of the inevitably victorious white supremacists. The most important element is an overwhelming contingency of white heroes who are stretched to the breaking point by a bevy of outrages and decide they must finally take a stand against their own government (fraudulently represented by black politicians and especially black soldiers) in defense of a higher law and order.

In contrast, Tourgée's novel contains a much more orderly demonstration of black collective action during which no one dies — in fact, no one is visibly armed — and several white "Union" men, besides Servosse, are present (121). In keeping with his subscription to separate spheres liberalism, Tourgée suggests that he supports the freedmen's claim to collective action as a civic duty. Servosse encourages Andy, his devoted black employee, to join the Verdenton Union League: "I do not see why it should not be a good thing for the colored people to do. It would teach them to organize and work together, and they would learn in it something about those public duties which are sure very soon to be cast upon them. Besides, it is by no means sure that they may not need it as a means of self-protection" (116). The meeting itself, officially led by the Verdenton League's black president, follows a ceremonial order and is conducted around a "small table, draped with a Union flag, and surmounted by a Bible and the Constitution of the United States" (124). There are "religious exercises," which Servosse is asked to lead, the induction of new members, the sharing of committee reports, and, of course, "the usual business 
of a secret order" (125). The white men, who clearly approve of the proceedings, have an ongoing private conversation, which continues in whispers throughout the formal meeting, during which they discuss their own fitness for and potential need of an organized Union League in the South so as to offset the potential numbers of the Confederate "Red Strings" (123-126). Tourgée's agreeable depiction of a peaceful, organized, and potentially integrated black collective appears to contradict Dixon's formulaic portrayal of black collective action as only and always riotous violence. However, the glaring problem with Tourgée's collective is that it takes no action. This, in effect, is why he is able to characterize this expression of black citizenship as peaceable and orderly: because it is essentially passive. This passivity speaks to the concerns white men, even sympathetic white men, encountered when faced with the concept of independent black citizenship. "While black voters frightened white men, African American militias terrified them. . . Black men could not constitute a legitimate body of 'the people,' fitted for public meetings, political rallies, or military service. When black men did take on these roles, whites portrayed them as comical and ignorant, or more often as impudent and riotous —as a mob" (Kantrowitz 69). Although promised liberties would be, to say the least, hard won, African Americans did assert their rights to vote or to engage in collective action, and they did so successfully without the guidance of white benefactors. Black men formed local militias and organized political societies independent of white rule, many of which included black women among their ranks. "Across the South in the late nineteenth and early twentieth centuries," as Leon F. Litwack observes, "blacks in increasing numbers mobilized to protect members of the community from arresting officers, abusive railroad and streetcar conductors, exploitative employers (who refused to pay promised wages or held workers in peonage), lynch mobs, and 
police violence" (Trouble 424). These community groups, exploited in Dixon's novel, are conspicuously absent, or, worse, rendered powerless, in Tourgée's narrative.

In fact, Tourgée's description of the Verdenton Union League is remarkably consistent with historical accounts of white wartime Union Leagues, in which benevolent white activists worked on behalf of African Americans, many of whom were still enslaved. Mark E. Neely Jr. suggests that wartime Union Leagues were overtly political and primarily limited to a bourgeois white elite, many of whom were New Englanders who could proudly trace their ancestry to the Mayflower (79-88). Wartime Union Leagues based in Boston, Philadelphia, New York, and New Jersey, for example, sent supplies and encouraged relief for Southern citizens who passed resolutions of loyalty to the Union, and they lobbied aggressively for African American rights in their own neighborhoods, especially on behalf of black soldiers and their families (92-93). According to Neely, the "legacy of the Union League Clubs, altogether forward-looking, was mixed. Because the clubs arose at a time when political opposition was suspect—during a wartheir members, some of them, were attracted also by an antiparty feeling. That impulse continued into urban good government campaigns and civil service reform, which were league programs from the start" (95). ${ }^{17}$ It is easy to see why Tourgée would have been attracted to the politics and prestige of these wartime Union Leagues, and also why freedmen would want to model their own collectives on this formula; however, it is also clear, in both Tourgée's and Neely's descriptions, that even radical whites would want to limit the participation of African Americans in such "grassroots" political action.

This is the sort of Union League on which Servosse imagines the Verdenton chapter will be modeled. He describes the earlier League, with a reverence anticipating Dixon's descriptions of the Klan, as "a society of men who were determined never to give up the Union under any 
hazard, but to uphold and sustain it with property and life if need be. It was a secret association; and its chief purpose was said to be to enable the loyal people of any neighborhood to muster the shortest possible notice, to resist invasion, put down riot, or enforce the law" (114). Tourgée's black Union League is not really an independent black collective at all, but the reconstitution of a white political group which now incorporates blacks into its membership and purportedly its leadership. Black leadership, however, as Tourgée's rendering of the Verdenton meeting illustrates, must be supervised by white men who, because of some obvious mark of dedication to the wartime version of Union, represent a heightened experience of citizenship. Servosse meets this qualification because of his prior service in the Union Army and his official designation as "Colonel." Similarly, Mr. Walters, a dedicated Southerner, is dubbed "good enough material for a Union League" following the telling of a story in which Walters resists enlistment in the Confederate States Army by violently beating several "conscript hunters" with a cane, shooting one of them with his own pistol, and then walking away unhurt (122-123). These are the white men who really make up the Verdenton Union League's leadership; the black president is a mere figurehead.

Tourgée's characterization of the Verdenton Union League attests to his generation's inability to conceive of black collective action independent of white leadership. In later white nationalist narratives like those penned by Dixon or Thomas Nelson Page, "any reading of the war as a site that changed the course of history, an unexpected moment of rupture producing citizen from slave, is quite inconceivable" (James 59). For Tourgée, the transition is incomplete; while he can, at the moment he is writing $A$ Fool's Errand, conceive of freedmen as citizens in the abstract, his conception is so limited that he cannot actually envision their acting upon that citizenship in the same manner as he might expect of a white man. As Hardwig observes, 
“Tourgée's notion of justice tends to rely on the progressive white community's power to rescue the helpless black community. From this perspective, 'real' justice for the black community is defined, meted out, and regulated by the white liberal community in opposition to the conservative white community" (7). Black social and civil rights remain bargaining chips in a white political balancing act which is fundamentally upset by actual physical resistance on the part of black citizens.

Tourgée's liberal rhetoric, then, can only be called "radical" in comparison to more “conservative" voices, like that of his contemporary William L. Royall. In his Reply to "A Fool's Errand By One of the Fools” (1881), Royall bitterly condemns Tourgée as an “imposter" who maliciously constructs misleading depictions of "the life and manners of the Southern people" (6-7). In short, Royall's political argument amounts to a regurgitation of antebellum disputes reduced to states' rights in which he relegates the plight of the freedmen and women to a matter of white Southern character. His primary concern is the location of democratic power, the power of law and order, with local governments, rather than with the "General Government" which Tourgée endorses. "Law," "order," and "property" are Royall’s keywords, with which he attempts to eclipse Emancipation and with it African Americans' transition from Southerners' property to citizen of the nation. For Royall, federal checks on local government create dissension rather than balance and imply a distrust of white Southern morality and ability to selfgovern: "The Republican party claims that there is a constant and unending conflict in progress between the negroes and the white people of the Southern States, and that it is necessary that the General Government should have power to interfere in that conflict to protect the negro, otherwise the white man will make him the victim of the most diabolical oppression" (67). Royall nearly manages to altogether avoid discussing African American citizenship along with 
equal protection under the law, whereas Tourgée's willingness to speak on behalf of federal intervention and protection for African Americans would have seemed quite radical, at least for whites of both sections.

Where Tourgée's and Royall's generation saw a potentially transformative gesture toward the working out of these intersectional conflicts of representation between whites, by the time Dixon wrote The Leopard's Spots, historians writing in the wake of Radical Reconstruction were promoting the image of a healed and reunited nation, more whole and solid for its triumph over troubles. "Our histories," W. E. B. Du Bois writes, "tend to discuss American slavery so impartially, that in the end nobody seems to have done wrong and everybody was right. Slavery appears to have been thrust upon unwilling helpless America, while the South was blameless in becoming its center" (714). The conspicuous agreement he finds among "sixteen studies of Reconstruction in the Southern States" conducted between 1895 and 1935, tells a deeper story of how conceptual reunion was achieved, or at least agreed upon (719). African Americans, however, as Du Bois indicates, are noticeably absent from the historical happy-endings, as they must be in order for these narratives of national cultural reunion to make sense. If no one was wrong, then no one must have been wronged, either by the institution of chattel slavery or by postbellum incarnations of this system manifest in lynching, Black Codes, tenant farming, wage slavery, grandfather clauses, voter intimidation, laws against interracial marriage, and disfranchisement.

James's observation that Dixon's "white nationalist fantasies" both rely on and perpetuate "a lateral notion of black history in which slavery, the Civil War, and Reconstruction are understood as a continuum" is also true of Tourgée's postwar vision (59). In white nationalist reconciliation narratives, African American history looks like this: "Blacks, finding themselves 
in the New World friendless and backward, were nurtured in the benign civilizing paternity of slavery. Helpless and immature, they could not have fought with any intent or 'manliness' on their own behalf against the South. In the final, tragic phase, the civilizing process was abruptly halted, leaving them absolutely unfit to hold the franchise in freedom" (James 59). Although his vision of the future differs significantly, Tourgée hardly contradicts such paternalistic accounts of African American history. By subjugating African American lived experience to fraught national and sectional politics, Tourgée's fiction engages in an extended political battle between white factions at the expense of African American subjectivity, therefore setting a perhaps unintended but very real narrative example for Dixon to follow. In the context of broader cultural instabilities, these battling white factions collectively eclipse and obscure white supremacy's structural denial of black rights and the corresponding enforcement of that denial through violence.

Du Bois's description of the 1863 New York draft riots in Black Reconstruction in America, 1860-1880 (1935) effectively foreshadows the distinct pattern of white violence that would become commonplace by the early twentieth century, solidified via the repetition of events like the Hamburg and Wilmington riots. Of the draft riots, Du Bois writes simply: "It was easy to transfer class hatred so that it fell upon the black worker" (103). By and large, the anger of the mob focused on African Americans: "They were the cause of the war, and hence the cause of the draft. They were bidding for the same jobs as white men. They were underbidding white workers in order to keep themselves from starving" (103). Similarly, animosity toward blacks in the post-war South often hinged on newly realized competition for work and wages and was mired in social and economic upheaval. According to Du Bois, "the poor white clung frantically to the planter and his ideals; and although ignorant and impoverished, maimed and discouraged, 
victims of a war fought largely by the poor white for the benefit of the rich planter, they sought redress by demanding unity of white against black, and not unity of poor against rich, or of worker against exploiter" (130). In both the violence of the draft riots and the turning of the poor Southern white against blacks of similar economic positions, democratic practice turns back on itself. White supremacy prevails over class consolidation, at least in part, because of the opportunities apparent to poor whites as a result of joining their fates with the planter class rather than with the slaves.

A war that was and was not about emancipating the slaves had unexpected and unconsidered results for diverse classes of whites in both sections. Reactions by poor Southern whites to the end of the war and the emancipation of the slaves reflected more general feelings of fear, prompted by subsiding exhilaration and impending realizations of what Emancipation might functionally and practically mean for those who had championed its cause and those who had opposed it alike. Du Bois writes: "Back of all the enthusiasm and fervor of victory in the North came a wave of reflection that represented the sober after-thought of the nation. It harked back to a time when not one person in ten believed in Negroes, or in emancipation, or in any attempt to conquer the South. This feeling began to arise before the war closed, and after it ended it rose higher and higher into something like dismay" (131). Blacks had served as Union soldiers, despite their initial exclusion from the ranks and early concerns that their enlistment constituted "an incendiary act" (Litwack, Storm 66). They had essentially proven themselves as capable as white men on the battlefield, and, as Union soldiers, they had been actively as well as symbolically involved in the South's crushing defeat (99). The military success of African Americans, like their proven capacity as free laborers, inspired in many Southerners as well as Northerners escalating feelings of hostility and aggression, as the freedmen increasingly posed a 
serious social and economic threat to abstract as well as to functional white supremacy. Just as they were, in 1863, "the cause of the war, and hence the cause of the draft," freedmen were, during the Reconstruction period, convenient scapegoats for everything from the South's defeat to increased labor competition in the North.

Historical accounts of the 1876 Hamburg riot, on which Dixon's fictional Independence riot is partially modeled, describe the evolution and consolidation of postwar white fear and ambivalence about the meaning of the war and of African Americans' participation in their own emancipation. The historical narratives, like Dixon's fictional narrative, begin with the white perception of a black threat to white sovereignty. Hamburg in 1876, like Wilmington in 1898, was a southern center of relative black political power. Despite the presence of a white rifle club led by prominent white supremacist Democrat Matthew C. Butler, many black men held official positions within the local Hamburg government, including trial justice Prince Rivers, a major general of the militia in which black activist and former Georgia politician Dock Adams served as commander (Kantrowitz 73). Both Rivers and Adams were veterans of the Union Army (Foner, Reconstruction 570). On 4 July, the black militia were drilling in celebration of the nation's centennial on "a wide Hamburg street, overgrown with weeds except in its wagon ruts" when two local men, Thomas Butler and Henry Getzen, attempted to pass, claiming the right-ofway and demanding the militia unit break ranks, to which Adams eventually acquiesced (Kantrowitz 73). Kantrowitz records "competing narratives of the July 4 confrontation," in which "Adams, for his part, noted that there was plenty of room on either side of the company for the white men to pass" while "Thomas Butler and his father Robert ... stressed that it was their wagon that had worn the ruts along the road. At first, they denied that the road was a public way" 
(74). The white farmers took their claims to Prince Rivers' court the following day, and he continued the hearing until 8 July.

As in Dixon's novel, public record reveals a perception by white men that their actions were defensive as well as civically responsible and that the black citizen soldier constituted an external threat rather than a symbol of integrated citizenship. Various historical sources record the actual riot events differently, but Kantrowitz describes a show of legal force by Matthew Butler on behalf of the white farmers in which he demanded an apology as well as the surrender of the militia's arms. Rivers found Adams, who, out of fear for his safety had "refused to appear in court," in contempt and offered to take custody of the weapons himself until the matter could be settled (Kantrowitz 75). ${ }^{18}$ The whites refused offers of mediation and gathered in the streets of Hamburg wearing red shirts. Along with reinforcements from nearby Augusta, Georgia, Butler's "red shirts" attacked the militia men who were barricaded in their drill room, "us[ing] a cannon brought from Augusta to break down the walls of the building" (76). Red shirts executed at least six black men whom they considered political threats before "they told the rest to run and then fired on them as they fled" (Kantrowitz 76).

Capitalizing on this particular historical context, Dixon mobilizes the contested black soldier in his fictionalized version of the Hamburg riot. Black soldiers, for Dixon, are the ultimate evidence of the paradox of black citizenship, at once evoking for whites terror and nostalgia for a bygone era. In Dixon's novels, James observes, “African American men in military uniform, the iconic symbol of a black future, simply signify two alternatives of regressive black masculinity: slaves who had followed their masters to war or illegitimate soldiers masquerading as the masters of whites during the military rule of Radical Reconstruction - characterized as a topsy-turvy, nightmarish period of "nigger domination"” 
(59). Thus James situates the contradictory image of the black soldier in historical terms. Lisa A. Long does so in psychological terms, characterizing "turn-of-the-century Negro Civil War Service [as] almost schizophrenically manifest[ing] both a subtext of rebellion and a rhetoric of restraint" (235). As Long further observes, "the image of the bestial black rapist/murderer lurks beneath the Negro soldier's uniform" (234). The African American soldier is an unpleasant enigma for white reconciliationists and for whites in general, having proved his capacity to occupy the most representative of citizenship roles, that of the Union soldier, but remaining excluded from other responsibilities of citizenship in times of ostensible peace. Dixon virtually solves this paradox in his novels by constructing the black soldier as the very image of riot and disorder and therefore fit to be neither citizen nor soldier.

Building on and perverting the more benevolent paternalism that Tourgée projects, Dixon depicts white men as victimized by black misuse of the democratic authority bestowed upon or allotted to them by white liberals like Tourgée. Dixon portrays a dire situation and a usually peaceful white community for whom there was no other choice but to retaliate against black subversives and their corrupt white benefactors. "Negro insolence," Dixon's narrator asserts, "had reached a height that made it impossible for ladies to walk the streets without an armed escort, and white children were waylaid and beaten on their way to the public schools" (415). That social relations have allegedly reached this veritable point-of-no-return before the white supremacist mob springs into action further serves to rationalize the need for retaliatory white violence and purportedly explains its excess as well as its potentially traitorous anti-government actions. As Kantrowitz observes, "former slaveholders and Confederate officers re-established their political authority on a foundation of white men's fears and expectations, convincing many white men that their armed struggle against a democratically elected government was legitimate, 
and perhaps inevitable" (67). This is the line that Dixon takes, at once dramatizing the inherent fitness for democracy of "virtuous" and dedicated whites and the unfitness of blacks and white blood traitors for the demands of egalitarian government. If democratic practice is messy, according to Dixon, it is the fault of these Others, who have no legitimate place in selfgovernment. Dixon's emphasis on the black soldiers as the impetus for the riot points selfconsciously to white men's contrived willingness to offer democratic participation to the masses and to the necessarily violent rescinding of that offer when that participation becomes too threatening.

Again emphasizing the dominant cultural conflict in terms of white political disagreement, Dixon stresses the involvement of white Republican Allan McLeod and his party's collusion with Negro farmers in instigating the Independence riot. The purported insolence of the black regiment is a secondary cause of the riot, a tool in the ongoing political battle between old personal and political rivals McLeod and Gaston. Gaston is personally identified as the "intended victim" of the riot, representative of white supremacy and the imagined white fraternity that is being undermined by McLeod and his Republican allies (418). Despite McLeod's efforts, the riot is ultimately a win for Gaston and the white supremacist Democrats, both locally and nationally: "Negro refugees and their associates once more filled the ear of the national government with clamour for the return of the army to the South to uphold Negro power, but for the first time since 1867 it fell on deaf ears. The Anglo-Saxon race had been reunited. The Negro was no longer the ward of the Republic. Henceforth, he must stand or fall on his own worth and pass under the law of the survival of the fittest" (418). A victory for local government, Dixon characterizes the outcome of the Independence riot as equalizing rather than as oppressive, a truly democratic triumph. Gillman has argued, "thus do white power brokers, like Dixon, borrow 
black victimization to make whites into victorious victims and enhance their own standing in the cultural struggle for the moral high ground waged in the context of lynching" (97). In Dixon's novel, organized black resistance is the result of moral corruption and white liberal defection and serves as a necessary site of comparison. Dixon presents armed collective action by African Americans, then, as evidence of the inevitable failure of the liberal project of incorporating blacks into the voting citizenry.

African Americans, however, often viewed the Civil War and Reconstruction in terms of "the second American Revolution" (Blight 133). As Litwack notes, "from the mouths of grandparents and parents, as the first freeborn generations heard them, the stories of enslavement, the Civil War, and emancipation bore no resemblance to the popular histories and schoolbooks" (Trouble 72). For them, the Civil War was always about Emancipation, and the political differences between whites merely aided in bringing about the necessary conditions. "To Joseph Sutton, born in 1885, the son of former slaves, the simple version of the Civil War he imbibed subverted both white southern and northern interpretations. 'The North couldn't whip the South, that's the way the slaves got free. And then, after that, they got the slaves in there, that made thousands and thousands more help for the North, and then the North could whip the South" (72). Not only does this alternative version of history acknowledge the reluctance of the Union to make the Civil War about emancipating the slaves, it also positions African Americans as determined agents of their own freedom, despite resistance from both Northern and Southern whites. Litwack records the stories of Reconstruction-era black families who adorned their homes with "portraits of Frederick Douglass, Booker T. Washington, and Paul Laurence Dunbar" rather than with images of white figureheads of freedom and democracy like George Washington or William Lloyd Garrison (73). For black leaders like Douglass, according to 
Blight, "emancipation and the Civil War were truly felt history, a moral and legal foundation upon which to demand citizenship and equality" (133). Many freedmen and their descendants embraced their rights as citizens as promised by the Thirteenth, Fourteenth, and Fifteenth Amendments and were prepared to defend those rights with violence if need be, just as they had done as soldiers in the Civil War.

Thus, Tourgée, Dixon, and Reconstruction-era African Americans all seem to be defining citizenship and popular representation in a democratic society similarly in terms of a civic duty and a Constitutional right to engage in collective action. Both A Fool's Errand and The Leopard's Spots, however, reveal a fundamental disconnect between the avowed principles of ideal American democracy and the actual practices of white supremacy and hierarchical citizenship. As James suggests in her critique of "melodramatic sentiment" like that employed by Tourgée and Dixon as "fanaticism," melodrama "is not a pedagogical tool pointing to right and wrong within a morally instructive universe; it merely appears to operate that way within a universe that is morally inert. There is neither 'good' nor 'bad,' no Union vs. Confederate, no abolitionist vs. slaveholder. There is only and always the 'middle,' which proves a dangerous space for black Americans” (87). In other words, Tourgée's and Dixon's melodramatic and sentimental novels elide the differences between white men in order to reassert white supremacy over blacks and to do so in a way that is a morally bankrupt and cowardly deferral of history's demands. Tourgée's tempered radicalism in A Fool's Errand wallows in this alleged middle ground, refusing or unable to take sides, and therefore contributes to Dixon's narrative solidification of absolute racial difference and his generation's refocused efforts to stabilize an inherently unstable culture via public and prolific racial violence. The middle, then, portends riot, both for blacks whose resistance cannot otherwise be defined under this purportedly amoral 
structure as well as for whites whose tentative supremacy and conceptual hegemony must be violently reestablished again and again.

\section{Notes to Chapter 2}

${ }^{13}$ Class is a significant factor in determining the fate of women in The Leopard's Spots: women of an elite socioeconomic class like Sallie Worth and Helen Lowell are married and/or escape punishment for their real and potential transgressions, while markedly lower class women like Tom Camp's daughters meet violent ends and suffer the indignities of rape. Even upper class women who die during the course of the narrative, like Mrs. Gaston, are indirectly driven to a relatively peaceful death rather than physically assaulted by black men or white. In The Clansman, however, Elsie Stoneman's voluntary leap to her death breaks this trend.

${ }^{14}$ David M. Chalmers offers an analysis of the Klan from its inception in 1865 to the late twentieth century, as does Wyn Craig Wade in The Fiery Cross: The Ku Klux Klan in America (Oxford UP, 1998). For studies which focus primarily on the Reconstruction-era Klan, see also Allen W. Trelease, White Terror: The Ku Klux Klan Conspiracy and Southern Reconstruction (Louisiana State UP, 1999), and J. Michael Martinez, Carpetbaggers, Cavalry, and the Ku Klux Klan: Exposing the Invisible Empire During Reconstruction (Rowman and Littlefield, 2007). For an analysis with an emphasis on African American resistance, see Kwando Mbiassi Kinshasa, Black Resistance to the Ku Klux Klan in the Wake of the Civil War (McFarland, 2006).

${ }^{15}$ Forrest had already led the massacre of captured black troops at Fort Pillow in Tennessee on 12 April 1864. When Confederate soldiers under Forrest's command captured the Fort, black soldiers were lynched rather than allowed to surrender. Forrest's deliberate defiance of military battle codes in the Fort Pillow Massacre would form the basis for a tradition of ritualized white violence against black troops and foreshadowed the 8 July 1876 Hamburg, South Carolina, Massacre and the 14 August 1906 "Brownsville Incident" in which a mob opened fire on a black regiment at Fort Brown, Texas, among others.

${ }^{16}$ For more on black women's involvement in postwar politics, see Elsa Barkley Brown, "Negotiating and Transforming the Public Sphere: African American Political Life in the Transition from Slavery to Freedom" in Dailey, et al., Jumpin' Jim Crow, p. 28-66.

${ }^{17}$ See Mark E. Neely, Jr., The Boundaries of American Political Culture in the Civil War Era, p.71-96, for a discussion of the complexity, uses, and purposes of white wartime Union Leagues. 
${ }^{18}$ Different sources list different reasons and different timelines for Rivers' charge of contempt against Adams. Foner has Adams appearing in court on 5 July when the original warrants were sworn out and held in contempt at this meeting for chastising Rivers "for even entertaining the complaint" filed by Butler (571). Kantrowitz postpones the confrontation and the contempt charge until 8 July, the date of Prince Rivers' scheduled hearing, and he records a contempt charge for "nonappearance" (75). Goff, in a fictional portrayal of the event, has Judge Rives hold Captain Doc in contempt for sitting down without permission (67). 


\section{Chapter 3. "Both Domestic and National"19: Three US Women's Narrative Interventions in Masculine Histories of Collective Violence}

Not coincidentally, the ratification of the nineteenth amendment in August of 1920, which finally and formally granted women the franchise, corresponds to the point at which literary critics note a rise in "overtly anti-lynching works of fiction by white women writers" which had, according to Sandra Gunning, up until this point "seem[ed] so few and far between" (111). Gunning further explains that black women's explicit novelistic engagement with the politics of racial violence was also until recently overlooked, as in the case of Pauline Elizabeth Hopkins's Contending Forces: A Romance of Negro Life North and South (1900), "a novel ostensibly designed to address issues of race, femininity, and domesticity" but in which scholars now identify the "explicit contrast of the promise of black domestic life in America with the crisis of lynching and rape" (111). Women novelists at the turn of the twentieth century, white and black, were not unconcerned with or disinterested in representing lynching or other manifestations of racial violence. Nonetheless, they did have to negotiate, in ways that male writers did not, a white masculine cultural narrative that most often cast them as passive or supporting participants in the masculine exchanges of war, revolution, resistance, and policymaking, despite the prominent role their bodies often played in dominant male narratives of the same.

Because cultural violence in this period was primarily represented and discussed in terms of the male participants, who were most often directly responsible for both individual violent acts and for assigning meaning to those acts, women authors' common experiences as women significantly shaped their narrative approaches to oppressive violence, organized resistance, and 
purportedly collective memory of these events. Whereas the male authors included in this study, like Charles Chesnutt, Albion Tourgée, and Thomas Dixon, take on directly specific and contemporary race riots, lynchings, and methods of organized resistance like those represented by the Ku Klux Klan, and do so with overt, immediate, and instantly recognizable political agendas, their female contemporaries characteristically employed more indirect strategies by which to level contemporary cultural criticism. Reinterpreting more distant historical events in order to comment on the present, the women authors I study in this chapter use melodramatic “feminized" modes of writing fiction to create parallel worlds where women's experiences are both paramount and reflective of a complex cultural dynamic in which gender and race are radically intertwined. Neither evasive nor uncomplicated, the representative novelistic strategies employed here by Pauline Carrington Bouvé, Mary Johnston, and Pauline Elizabeth Hopkinsadolescent fiction, historical romance, and maternal melodrama, respectively — reveal not only underrepresented approaches to collective mob violence but also the subversive ways in which women authors engaged with masculine white supremacist cultures of violence on their own terms.

Biographically, Bouvé and Johnston have much in common with each other but share little with Hopkins. Bouvé was born in Little Rock, Arkansas, and raised in Luray, Page County, Virginia, by her mother, Anne Bouldin Cabell, after the death of her prominent father, Albert Rust (1818-1870), Democratic congressman for Arkansas and brigadier general in the Confederate States Army. Bouvé's education by private tutors, as well as the relative social prominence of both the Cabell and Rust families, indicates the probability of an upbringing steeped in the nostalgic glory of the Old South and largely traditional Southern values. ${ }^{20}$ However, Bouvé's 1894 move to Boston and her subsequent 1898 marriage to Thomas Tracy 
Bouvé mark her expatriation from the South. ${ }^{21}$ Similarly, Johnston was a well-read independent Southern white woman of means who was bound to a cultural heritage that she also criticized. Johnston spent her childhood plagued by illness and, unable to attend school outside of the home except for three months in 1887 at Mrs. Roy's School for girls in Atlanta, she was largely selftaught by virtue of unlimited access to her father's extensive library (Cella 18-20). After her mother's death, Johnston assumed a leadership role within her family. She never married and amassed considerable wealth on her own, remaining dedicated to her family and sharing her Virginia home with her unmarried siblings Walter, Eloise, and Elizabeth throughout her life (Cella 16).

Hopkins, however, was born in Maine to free parents of color and raised and educated in Boston, a city with a large African American population and a prevalent tradition of radical activism. Her first literary achievement came at fifteen when she won a contest chaired by William Wells Brown with the best essay explicating "The Evils of Intemperance and Their Remedy" (Carby, Womanhood 122). Whereas Johnston and presumably Bouvé were able to make their livings primarily from the proceeds of their writing, Hopkins worked as a stenographer during the 1890s and at different times throughout her life. In 1899, when Hopkins was forty years old, she was instrumental in the founding of the Colored American Magazine, which she edited until 1904 when Booker T. Washington assumed editorial control.

From their variously liminal subject positions as women, Bouvé, Johnston, and Hopkins present the hypothesis that it takes an outsider to recognize structural racism. Like W. E. B. Du Bois, who describes "double-consciousness" as the "sense of always looking at one's self through the eyes of others, of measuring one's soul by the tape of a world that looks on in amused contempt and pity," as an essential feeling of "two-ness," these women authors suggest 
that there is a kind of clarity in their marginal experiences in a way that both diverges from and complements Du Bois (Souls 11). Bouvé, Johnston, and Hopkins, to different degrees, promote an outsider consciousness via the characters in their novels while doubly presenting their authorial selves as outsiders capable of recognizing in unique ways, in ways that men cannot, the innate counterintuitiveness of white supremacist narratives of violence. Furthermore, each novelist's conception of this outsider consciousness shapes her individual engagement and reinterpretation of the historical archive.

Significantly, the central historical events of Bouvé's Their Shadows Before: A Story of the Southampton Insurrection (1899), Johnston's Prisoners of Hope: A Tale of Colonial Virginia (1898), and Hopkins's Winona: A Tale of Negro Life in the South and Southwest (1902) are genuine servile rebellions rather than overt acts of terrorism hidden beneath the language of race prestige and white supremacist self-preservation. Bouvé recreates Nat Turner's notorious 1831 Southampton Insurrection via the perspective of a sympathetic white child. Johnston's text, which is based on the 1663 Gloucester County, Virginia, revolt known as the Servants' Plot, treats a colonial, pre-Revolution slave revolt (or series of revolts) involving Native Americans, African Americans, and white political dissidents and those of lower socioeconomic classes, all of whom are enslaved or oppressed by a white planter elite. In Winona, Hopkins aligns her multiracial protagonists with white revolutionary John Brown at Pottawatomie, Kansas, in 1856, with a prospective glance toward the Harpers Ferry uprising of 1859 . Unlike the Wilmington race riot or the concentrated violence of the $\mathrm{Ku}$ Klux Klan, which were only nominally illegal, ultimately in service of the white power structure, and often carried the explicit blessing of the law, the Servants' Plot, the Southampton Insurrection, and the raid on Harpers Ferry each 
represent fundamental challenges to the existing power structure by those who are not protected by complicated official narratives of justification.

As witnesses to and at times participants in the unfolding of an idealized masculine struggle documented within the contested terrain of popular novels like those penned by Chesnutt, Tourgée, and Dixon, the women novelists herein treated reinterpret a dominant sociopolitical narrative from which they are excluded and which is at the same time ultimately dependent on their acquiescence to a white male authority. As they work to navigate this contested terrain, these authors raise questions about their own personal and collective responsibility within a fundamentally fractured system of American democracy and about the ways American women exist within, cope with, react to, and, most significantly, resist this particularly incongruous culture. Representing Nat Turner and violent slave revolt via a sympathetic white child's perspective, Bouvé takes a radical step in laying claim to an alternative voice for white women and therein an alternative narrative of positive black masculinity. This radical step is also problematic, because although Bouvé's Penelope speaks on Turner's behalf, she also speaks for him. Johnston is the most conservative and the most fatalistic of the three writers, more openly representing the chaos that results from trying to remake or escape the cultural order, the same chaos Bouvé works to smooth over. Representing a community that is formed on the elaborate contradictions that remain unreconciled in the other two novels, Hopkins's Winona embraces the chaos of culture in "the disruliness" of her novels, to borrow a fitting term from Elizabeth Ammons (211). These novels, in working to find new ways to challenge white supremacist narratives and their implicit violence, also reveal the fundamental paradoxes of culture and the built-in barriers to their own engagement with this narrative that these women encounter along the way. 


\section{"White Lamb" for the "Black Sheep": Pauline Bouvé's Their Shadows Before}

In more traditional narratives of racial history and white fraternity, like Tourgée's $A$ Fool's Errand and Dixon's The Leopard's Spots, white women, and, significantly, the choices they make, represent the resolution of internal fractures within masculine cultures of violence. In this way, white supremacists developed a standard narrative that dually depended on alleged rape victims' silence and held white women responsible for the need to lynch in the first place. Many white women, however, supported this narrative with their willingness to attend and to celebrate lynchings. Others publicly embraced the rhetoric of black rape and white rescue that located them at the center of "civilization." In August of 1897, white temperance reformer Rebecca Latimer Felton gave a speech, "Woman on the Farm," to the members of the Georgia State Agricultural Society at Tybee, in which she advocated the lynching of black men as a preventative for the rape of white women. As LeeAnn Whites observes, versions of the final line from Felton's speech, the "one sentence_- 'if it will save one white woman, I say lynch a thousand black men'-would be repeated endlessly in the press commentary, and by Rebecca Latimer Felton herself in the months and years that followed" (149). Felton's speech was reprinted in the Wilmington Messenger during North Carolina's statewide white supremacy campaign of 1898, and Alexander Manly's editorial response, published in his own Daily Record in August of 1898, is consistently cited by historians in connection with the Wilmington race riot. Thus building upon Felton's assertions that white men failed to protect white women, Glenda Elizabeth Gilmore contends, Manly "accused white men of failing to live up to the demands of patriarchy, an accusation that Felton might make with impunity but that Manly made at considerable peril" (106). Interestingly, the impunity granted to outspoken white women also 
presupposes the cooperation of other white women like Bouvé, despite her novelistic refutation of these lynching narratives.

Set primarily in 1830 and 1831, Their Shadows Before is a radical revision of popular cautionary tales of inherent black savagery and the dangers of black citizenship in which Bouvé focuses instead on the tender relationship between Penelope Winston and Nathaniel, between the experiential woman and the masculine historical narrative. Writing at the close of the decade which saw the deplorable "height" of lynching, Bouvé challenges the conscious, cultural separation of the past from the present implied in the "happy darky" images of plantation mythology, emphasizing instead a distinct continuity between Turner's 1831 insurrection and the politics of the post-Reconstruction South. In depicting the infamous Nat Turner as a conscious and conscientious actor, focused, driven, and vindicated in his mission if not his methods, Their Shadows Before offers an alternative narrative of positive black masculinity in defiance of postReconstruction stereotypes which, as historian Grace Elizabeth Hale observes, limited African Americans to the minstrel figures of "the comic and contented slave" (51) or to the "flat and caricatured blacks of Reconstruction" in fiction "who had become the easily manipulated tool[s] of corrupt and scheming and often northern whites, granted either a dumb and petted loyalty or a beastlike agency to steal and rape and kill" (75). Significantly, Bouvé constructs this alternative image of Turner by historicizing Penelope's experience as a white child (who will be revealed as a woman reflecting on her childhood in the novel's "Finale"), thereby challenging not only the stereotypes themselves but their social construction through white masculine narratives of black violence against white women.

By privileging the voice of the white woman, who is customarily rendered merely a symbol of property or of progeny to be alternately raped or protected, Bouvé protests standard 
male narratives of extralegal violence and justification. It is noteworthy that Forum critic Benjamin W. Wells describes Their Shadows Before as "a story of the Southampton County insurrection of the Virginia negroes in 1831, combined with a very pretty idyll of girlish love and instinctive unsophisticated righteousness," thereby rhetorically separating the gendered experience of Penelope from the historical memory of the insurrection itself (507). This is just the sort of raced and gendered distinction which Bouvé works to negate when she renders the insurrection a production of Penelope's experience and recollection. Accordingly, Bouvé capitalizes on her articulate youthful protagonist who is doubly excluded from the masculine public sphere of politics and systemic violence by her age and sex and who is ideally positioned, in terms of age, race, and privileged socioeconomic status to privately identify with the black rebel leader in a desexualized context and to speak publicly on his behalf.

In their refusal to acknowledge the centrality of Bouvé's prepubescent protagonist to this narrative of violent insurrection and equally violent retribution, contemporary readers either missed or willfully ignored Bouvé's sharp divergence from other late-nineteenth century white writers' narrative reshaping of the messy history of slavery and its legacy for the new century. Although historian Scot French has recently praised Their Shadows Before, calling it the "boldest challenge to the proslavery image of Nat Turner as a bloodthirsty religious fanatic who hated all whites" (160), contemporary reviews upon the novel's release in December of 1899 were generally positive but politically noncommittal, merely anticipating "the future work of the author" (Wells 507). These marks of hesitation and the tenuous support in the language of early critical assessments imply an uneasiness about the unknown author's politics, yet white critics overwhelmingly assumed that Their Shadows Before was yet another nostalgic tribute to the "faithful slaves" of the Civil War era. A publisher's advertisement in the February 1900 
Bookman describes the novel as "founded with great skill and delicacy on the story of Nat Turner's insurrection, the servile rising which so terrified the planters of Virginia and the South seventy years ago" (833). This is a marketing strategy which both hints that an implicitly white, adult readership would find the novel's outlook familiar and sympathetic and ignores the fact that the novel is stylistically designed for an adolescent audience. This is typical of contemporary reviews, which tended to misleadingly or mistakenly characterize Their Shadows Before as "vivid" local color, wherein the youthful narrator appears as merely a genre-specific technical necessity, a narrative device designed to allow the author and her readers entry into the slave quarters, a space both forbidden and fascinating to white adults.

Uniquely positioned to reframe the conflicts of men, Penelope represents a move away from masculine cultures of violence and toward more traditionally feminine, experiential, instinctual means of cultural organization. As a child in the process of acquiring adult knowledge of normal cultural behaviors, Penelope's naïveté emphasizes the counter-intuitiveness of slavery as an institution and of underlying assumptions of essential racial difference. Her coming of age is central to her revisionist narrative as well. As Mary Kemp Davis observes, "the prepubescence of Penelope is an insistent theme in Their Shadows Before. Instead of focusing on Penelope's transition from girlhood to womanhood, Bouvé depicts Penelope's resistance to the ruling elite's social indoctrination" (174). The paradoxical manner in which she becomes a slaveholder proper epitomizes Penelope's relationship to slavery and her understanding of absolute racial difference as an education she is not prepared to receive. Her grandfather signs "Lame Jim" over to her after she steps between the disabled slave and the overseer's lash, receiving Jim's blow on her own shoulders (37). Penelope's instinctual act of self-sacrifice, a split-second decision made ostensibly without cultural or social influence, overturns white supremacist discourses of slavery 
as reflective of the "natural" order and instead posits white violence against blacks, particularly disabled individuals ostensibly under the care of white guardians, as unnatural. Twice marked as the "White Lamb" which will be sacrificed for the "Black Sheep" (25) and then with her own blood and by Turner's own hand (30), a mark of cooperation and therefore immunity, the woman-child Penelope occupies a "liminal space," to borrow the term from Davis, between innocence and knowledge, between authority and insurgent.

Bouvé's decision to render Penelope a pre-sexual child and to subordinate Penelope's sexual maturity to her cultural maturity is a central function of the novel's subversion. Penelope's indeterminate age and level of sexual maturity—she has a bit of a crush on Basil Mortimer, her tutor, but she still sees him in the childish terms of a fairytale prince-places her immediately within the "gray areas" of antebellum rape and statutory rape laws with respect to "widespread confusion about age, consent, and coerced sex" (Sommerville 45). As Diane Miller Sommerville observes, the legal age of consent in most antebellum Southern states was ten years, which Virginia had, by the time of the Civil War, raised to twelve (44). After having saved Penelope from death at the hands of his own men during the uprising, Turner takes her to his cavernous hideout in the swamps adjoining her grandparents' plantation where he treats her only with tenderness, mercy, and respect. Upon realizing that she is in her nightgown, Penelope becomes embarrassed, recalling that she "dragged the rough blanket from my improvised bed, and drew it close about me." Nathaniel's response registers consciousness of Penelope's subtle movement but renders the social implications therein uncertain: "II could not help it,' he said in a quaintly apologetic tone. 'Your life was in the balance: the men were mad"' (138). Despite her exaggerated helplessness and the isolation of the cave, Penelope perceives no threat, sexual or otherwise, and Nathaniel never gives her reason to be afraid. 
The much-anticipated rape never occurs, foregrounding the artificiality of "the image of the menacing black rapist," which Sommerville, among others, concludes "did not become the obsession of the southern mind until sometime after emancipation" (21). Correspondingly, the image of "lawless, unrestrained lynch mobs bent on vigilante 'justice' and retribution" was largely absent in response to rape cases in the antebellum South (20). As Sommerville makes clear, antebellum cases in which white women accused black men of rape or attempted rape evoked varied responses from members of the local white communities, primarily dependent on the class status of the woman, with poorer white women and women without "male protectors" like husbands, fathers, or brothers receiving little or no community support. In many cases, community members, including other women, testified as character witnesses on behalf of the alleged rapist, even if he was a slave or free black, and against a white accuser if she was considered to be a woman of ill repute (or even if she was the daughter of a woman whose reputation had been somehow damaged).

While penalties for slaves and free blacks convicted of rape were undoubtedly more severe than they were for white men found guilty of similar charges, the overwhelming hysteria about black rapists that emerged after emancipation was not present in the antebellum South. Relative intimacy between black male house servants and white women and children was actually commonplace in the antebellum South, as Penelope's relationship with Uncle Isham implies. Martha Hodes argues that the term "miscegenation" was not even coined until the presidential campaign of 1864, when it was first used by Democrats as a tactic for disparaging Lincoln and the Republican party, and it was not until Reconstruction that "white southern politicians beg[a]n to conflate the newly won political power of black men with the issue of black male sexuality" (230-231). This tactic was alive and well in the late 1890s, all the more 
effective because of the circular ritual punishment of lynching and the oft-accompanying castration. At the same time, this shift in popular representation emphasizes the generational differences between the paternalism of the Old South and the racial separatism of the New South.

That Bouvé does conjure the white mob bent on retribution at any cost, significantly in response to a slave uprising rather than to an accusation of black rape, identifies the white perception of a common threat in antebellum slave revolt and in postbellum black social and political "violations" translated as black rape. While Turner remains at large in the aftermath of the revolt, Basil Mortimer, Penelope's northern abolitionist tutor, is suspected of inciting the insurrection and is jailed by Sheriff Lawson, ostensibly for his own protection. Local whites "have done swore to swing Nat Turner or the young feller. It 'pears like they don't care so much which one it be, so it's one" (158). The Sheriff's strategy, which as he explains is to head off the mob — "Ef they find out he's already been arrested, it may simmer 'em down" (158-159)— positions the law as moving in response to the mob, not the other way around. The backward nature of the legal machine nullifies any resistance on behalf of Mortimer, even by his powerful, conservative, Southern friend, Penelope's grandfather Winston, rendering the white mob in complete control. The crushing force of the opposition to Mortimer's divergence from cultural norms - his real crime is conducting Sunday afternoon Bible classes for Winston's slavesunderscores the need for radical, perhaps even violent, action if any measure of success is to be achieved and thereby lends credence to Turner's insurrectionary tactics. In complicating the relationships between the lynch mob and the law, between the law and the private citizens it supposedly represents, and between the experiences of private citizens and the cultural norms by which they self-govern, Bouvé also stresses the contrived differentiation between the legal violence of executions and the insurrectionary violence of men like Turner. 
Bouvé, in fact, recreates Turner not as an isolated insurgent but as a true prophet whose gallows declarations of future bloodshed turn out, in retrospect, to be accurate in predicting the Civil War and the eventual emancipation of the slaves. In the novel's "Finale," Penelope has aged "nearly three decades" and is now living at the North, the wife of her childhood tutor. The year is 1859 , as Penelope recalls "Basil brought in a paper yesterday, containing a detailed account of John Brown's raid at Harper's [sic] Ferry" (200). This news both portends a "great national struggle" and reminds the couple of "that dreadful day in Southampton" when the two witnessed the hanging of Nat Turner for his role in the uprising (201). Penelope recalls not only Turner's death but his final prophecy: "Three times ten years shall come to pass before the deliverance shall be. In a vision of the future, the Lord hath shown to me, Nathaniel, his prophet, a freed nation and a river of blood! White men, there shall arise one of your race in a far land, and blood shall be shed and the bonds shall be broken" (198). Bouvé's contiguous timeline places Turner's insurrection in the same moral category as John Brown's white-led 1859 raid on Harpers Ferry and at the very least on a par with the "noble" bloodshed of the Civil War. In this way Bouvé identifies cooperative antislavery violence as a matter of modified masculinity rather than of race and renders Turner and Brown allies of an idealized Union rather than traitors of a white supremacist fraternity.

Instead of altogether condemning a masculine social structure, Bouvé alters conventional white supremacist narratives by reinscribing Turner's violence in terms of a positive black masculinity. While Bouvé's Turner is a murderer, she characterizes his crimes as deliberate, discerning, and, above all, divine, a direct refutation of standard narratives of black violence as predatory and bestial. Whether or not Nathaniel is truly a prophet of God, his conviction is repeatedly reaffirmed and respected by whites. Penelope declares before his trial that "Uncle Nat 
will not tell a lie," an assertion verified by her henceforth skeptical grandmother Winston (182183), and Mortimer assures Turner on the eve of his execution that "I believe you think what you say is true" (193). Discussing the enigmatic Nat Turner in the context of Thomas R. Gray's Confessions of Nat Turner (1831), Franny Nudelman asserts that "if Turner's fanaticism serves as an explanatory function for Gray as he tries to pathologize Turner's uprising, it also allows Turner to lay claim to divine authority. Boasting a form of knowledge that cannot be verifiedknowledge of God's will-Turner places himself beyond the reach of careful observation" (60). In refusing to undermine Nathaniel's spiritual conviction and in accentuating the mystical qualities of the man through Penelope's chance experiences with him—his inexplicable taming of Travis's wild bull and his mesmeric influence over Penelope's memory in the wake of the uprising —-Bouvé corroborates Turner's divine faith, stopping just short of the unknowable.

Bouvé links the Southampton insurrection and the raid on Harpers Ferry through Nathaniel's prophesy, suggesting that Turner's uprising both inspired and made possible Brown's raid, which, in turn, was a deciding factor in instigating the Civil War. Following Bouvé's logic, Turner's revolt was therefore successful, as her Nathaniel claims, because it indirectly caused the Civil War and the eventual emancipation of the slaves. Nathaniel's directives from God are never revealed, even though Bouvé refuses to either dispute or directly substantiate their existence. What she suggests, though, through her retrospective confirmation of Nathaniel's prophesy, is that perhaps Turner knew all along that his mission would fail initially, that he was meant to be martyred, because his actions were part of a larger process of cultural revolution, that his work was, in fact, successful, specifically because of its relationship to John Brown (also martyred) and the future of antislavery resistance. 
Bouvé was not the first to compare Turner and Brown. In the wake of Brown's attack on Harpers Ferry, as French observes, "newspapers in at least five major cities-San Francisco, Louisville, Philadelphia, New York, and Boston—drew parallels between the Harpers Ferry raid and the Southampton insurrection of nearly three decades before," alternately downplaying the potential repercussions of the event and emphasizing the widespread rebellion it portended (101). As Du Bois attests in his biography of John Brown (1909), Brown most certainly knew of Turner's revolt by the time of his raid on Harpers Ferry, just as he surely knew of Gabriel Prosser's "formidable uprising in Virginia" in 1800 and Denmark Vesey's 1821 rebellion in South Carolina, which Du Bois describes as "one of the shrewdest Negro plots that ever frightened the South into hysterics" (37). Hannah Geffert also describes Brown's detailed knowledge of the Turner and Vesey uprisings, of Toussaint L'Ouverture and the Haitian Revolution, of the Underground Railroad and resistance to the Fugitive Slave Act, and of coconspirator Harriet Tubman's success in using "the Great Black Way" through the Appalachians and via Harpers Ferry in assisting escaping slaves (24). ${ }^{22}$ Geffert suggests that previous insurrections, Turner's in particular, not only inspired Brown's conviction in leading the raid on Harpers Ferry but also that he studied them in order to determine the best way to execute his attack and to gauge the potential success of multiple approaches. Yet "Brown made no mention of Nat Turner or the Southampton uprising in his public comments on the Harpers Ferry raid," according to French, and, "if anything, he sought to avoid any association with slave conspiracies, past or present" (105). Brown's relative silence on the issue, however, does not negate the influence of Turner and other black revolutionaries on Brown and his supporters, nor does it mean that Brown disapproved of Turner's actions. ${ }^{23}$ Known as "a man who would never state more than it was necessary for him to do," Brown's silence was characteristic (Richard 
Realf, qtd. in Du Bois). In fact, Brown biographer Benjamin Quarles notes that Brown held Nat Turner "as high in his admiration as George Washington" (64-65). ${ }^{24}$

Race, then, becomes secondary in Their Shadows Before to questions of morality and violence and corresponding distinctions between higher law and the laws of man. Bouvé remains steadfast in her support of abolitionism and anti-slavery measures yet concerned about the moral contradictions inherent in the use of violence to effect cultural change, even if she sees that cultural change as a moral necessity. Bouvé tentatively validates Turner's methods as well as Brown's by rendering more moderate approaches insufficient, yet she chastises Turner, through Penelope, for committing and sanctioning violent acts against individuals, particularly women, children, and the elderly. It is significant that Bouvé wants to defer judgment of Turner to a higher power, that her child narrator is at once bonded to the man and horrified by his deeds. Even as an adult, Penelope remains dedicated to her childish declaration that "if those people want to set the slaves free, why, I am an Abolitionist, too!" (96). However, as the child Penelope learns through her relationship with the fictional Nat Turner, determining right from wrong is not necessarily clear or easy. Bouvé's retrospective vindication of Turner is supported by Nathaniel's differentiation between the law of man and the higher law of God. When asked by Penelope after he has rescued her from the chaos of the revolt, "Don't you know God says, 'Thou shalt not kill'?” Turner replies, “I fulfilled the Law. They will kill me, and it will be man's law" (137). Turner is indeed killed; the child Penelope watches "a dark object sw[i]ng in mid-air from the cross-piece at the top" (198-199). Yet, Bouvé's very retelling of his story, her insistence on a prophetic, merciful, and sympathetic Nat Turner, belies the futility of his aborted insurrection and his death at men's hands. 
Nathaniel's determination to entrust Penelope, "the white child," with his "testimony" (192) before his execution explicitly links the purportedly private and apolitical experiences of white women and those of black men in fundamental opposition to a masculine culture of white supremacy. Penelope is the principal historical witness, and it is her testimony — rather than Turner's, the text of which is never revealed - that stands as authoritative record of the event and its contexts. Bouvé, like her character Nathaniel, entrusts and calls on white women to counteract white supremacist violence by neutralizing the powerful narrative formula by which masculine cultures of violence self-replicate. By writing herself out of the role of victim and positioning herself instead as Turner's ally, Penelope exposes the overt function of lynching as the masculine management of incongruent norms.

In this way, Bouvé emphasizes the mutually contingent identities, to borrow John Ernest's term, of white women and black men. For John L. Grigsby, "Bouvé's message to young women that they can control their lives and destinies," as he reads her narrative purpose, and "the central role of Penelope as the possessor of Nat Turner's story" negate the autonomy of black male characters like Uncle Isham and even Nathaniel (56). This argument assumes that Penelope's voice cancels out Turner's, that white women are fundamentally agents rather than victims of white supremacist violence, and therefore presupposes that black men and white women cannot be allied in opposition to white supremacy. Grigsby is particularly tough on Bouvé's Uncle Isham, whom he compares to Stowe's Uncle Tom, unfavorably convicting both fictional characters of setting a harmful and lasting example of corrupt black masculinity for both blacks and whites. In isolating particular Uncle Tom-like characters and judging their narrative construction as though it occurred in an asocial vacuum, Grigsby also condemns Bouvé's Isham, G. P. R. James's Old Zed, and Arna Bontemps's Ben as feminine and sycophantic in much the 
same one-dimensional way as white supremacist histories have condemned Nat Turner as brutal and bloodthirsty.

Both of these perspectives are faulty in that they adhere to a rigid and formulaic social order that defines blackness and womanhood in absolute terms. These Jesus (Uncle Tom), Judas (Ben), and Job (Isham) characters and their creators are herein accused of individual personal failure; Grigsby expects them to somehow make a clean break from an oppressive history and from culture in general in order to live up to his expectations of black masculine militancy. Significantly, Grigsby never acknowledges that his analysis of Uncle Tom-like black characters - by his definition, those who repeatedly sacrifice themselves for their white masters - occurs in the context of novels expressly concerned with violent insurrection: James's The Old Dominion (1856), Bouvé's Their Shadows Before, and Bontemps's Black Thunder (1936). ${ }^{25}$ Grigsby posits ideal black masculinity as hyper-masculine in opposition to white femininity, while Bouvé positions the civil and social rights of white women and black men as neither historically fixed nor independent of one another. There is nothing fundamentally opposed about the behaviors of Uncle Isham and Nathaniel in Bouvé's novel. In fact, the accommodationist choices of characters like Isham, when read in the context of the more radical, violent choices of literary and historical characters like Nathaniel and Gabriel, present an extremely complex picture of the kinds of cultural and personal negotiations inspired and required by an inherently contradictory social order.

Bouvé posits the white woman-child as speaking on behalf of the black man, who is, significantly, a black prophet rather than a black rapist. However, the white woman is still speaking for the black man, who has no voice other than the one she gives to him. Here Bouvé's radical purpose is nearly thwarted, because she does not know how to let Nathaniel speak for 
himself or what to do with his voice. An interview she conducted with Charles Chesnutt in August of 1899 for the Boston Evening Transcript offers interesting insight into Bouvé's conflicted relationship with race at this time. Even as she insists on characterizing Chesnutt as variously marked by his "aboriginal ancest[ry]" and on describing The Conjure Woman (1899) as displaying "distinctly negro humor," Bouvé celebrates Chesnutt's writing as "genius" and counts his work, along with Booker T. Washington's The Future of the American Negro (1899) as important "signs of the times" (100-103). Her almost defensive repeated mention of Chesnutt's "bitterness" toward the white people of the South also implies an ingrained paternalism as well as a limited, even uncomfortable, respect for Chesnutt's politics.

Even as she critiques a masculine culture that appropriates white women's voices in service of white supremacy, Bouvé cannot overcome the more seemingly benign elements of this culture. She cannot see beyond a reinterpretation of the past, or mobilize her vision of positive black masculinity for anything much beyond the prevention of violence in her postReconstruction present. Neither can the liminally positioned Penelope. In some ways, Bouvé's redeployment of the trope of the white woman's choice remains within the frame of the narrative established by white men like Tourgée and Dixon, because the white woman simply makes a different kind of choice. At novel's end, Penelope, the privileged white Southerner, is married to her Northern abolitionist tutor, and she lives at the North, reading about the ongoing violent struggle against slavery from an appropriately safe distance.

\section{"With but a change of masters": Mary Johnston's Prisoners of Hope}

If Bouvé's Their Shadows Before falls short in its effort to reinscribe social codes and open a continuous line of communication between white women and black men, Johnston's 
Prisoners of Hope succeeds in depicting the utter chaos that results from similar failed attempts to subvert the existing social order. Johnston's critique of masculine cultures of violence via the genre of historical romance is perhaps the most conservative, in terms of ideas about the relationships between race, class, and gender, and it is certainly the most fatalistic of the three novels. Critic Lawrence G. Nelson rather haughtily characterizes Johnston, as a woman and a writer, as "patrician, conservative, and traditional to the core of her being," yet he is perhaps more accurate than even he might have imagined when he observes that "her themes arise out of the passions of men in time and history, out of their ambitions, jealousies, rivalries, and the havoc and desolation they cause" (78). Of course, Nelson fails to place appropriate emphasis on the fact that it is specifically men, and not women, even in his estimation, who are wreaking havoc and destruction throughout the histories of Mary Johnston's imagination.

Prisoners of Hope follows two parallel conflicts that ultimately converge at novel's end with little, if anything, having been accomplished, other than the reaffirmation of white male authority and the displacement of class allegiance by race. Godfrey Landless, a wronglyconvicted indentured felon from London, is the novel's white male protagonist, purportedly possessed of an outsider's perspective primarily because of his national identity and his status as a slave on the Verney plantation. Johnston stresses, however, Landless's political sophistication as the reason for his fraudulent incarceration, which positions him apart from the "real" criminals and the people of color held in race-based slavery. Despite his class allegiance, he is, at bottom, a white man, an identity at the root of both of the novel's parallel conflicts. Accordingly, people of color and white women, all of whom shape the novel's unfolding plot in important and irreversible ways, nonetheless occupy secondary positions determined by their relationships to and with the novel's white male characters. 
Landless oscillates back and forth between privileging his star-crossed romance with Patricia Verney, his master's daughter, and his leadership role in a colonial servants' revolt against the local planters, including Colonel Verney, Patricia's father. Landless's dual identities as republican revolutionary and as Patricia's friend and lover are ultimately incompatible, less due, apparently, to any internal fault of his own than to his fixed subject position in a rigidly hierarchical culture of oppression regulated through violence. Landless's two passions-love and liberty - are not in and of themselves irreconcilable; in fact, they are complementary. Yet the inharmonious way in which Landless goes about seeking freedom and a more humanitarian democracy through violent revolution squashes the possibility of his achieving either. Landless's inability to negotiate his conflicting responsibilities to Patricia and to his fellow revolutionaries simultaneously marks this conceptual distinction as unnatural and counterintuitive. In this way Johnston positions the masculine world of the public-political and the feminine world of the private-emotional as inextricably intertwined, at the same time making clear that the contrivance of white masculine dominance is directly responsible for Landless's doubly-wrought failure. Because the masculine is irrevocably marred by artificiality, structural inconsistencies, and the circular and self-replicating violence of revolution required to maintain the social and political control of white men, Johnston's narrative subtly privileges the feminine, which is marked instead by sincerity, intuition, and compassion.

Johnston's late nineteenth-century adaptation of the 1663 Servants' Plot begins with the hopeful suggestion that inter-racial cooperation among the servant classes is both possible and likely, if not yet realized. When Landless arrives in Gloucester County, Virginia, from London via Jamestown in the first chapter, a well-organized insurrection is already in the works, engineered by white slaves, indentures and felons from Newgate prison, victims of England's 
Act of Uniformity, "Oliverians" and "Roundheads" who are out of favor with the current government because of their political loyalties, and "fanatics" of the "Muggletonian" persuasion. All of the leading conspirators are white, and, despite profound political and religious differences, all purportedly desire "a way to recover [their] liberty, and with it, the liberty of a downtrodden brethren" (67); in short, the formation of "a republic" (68). The formation of this republic, of course, requires the displacement of the current ruling class, Governor William Berkeley and Royalists loyal to Charles II. Landless, who identifies himself as having been "a Commonwealth's man," is induced to join the conspiracy by its then-leader, Robert Godwyn, humble mender of nets and former Oliverian soldier who knew and fought beside Landless's father in Europe. Godwyn proposes a slave insurrection as the way to attain the functional republic of which they speak and for which they have ostensibly, as Cromwell supporters, been fighting for years in England (70). Unfortunately, Godwyn and his fellows have not taken into consideration the agency or the desires of the black slaves whom they intend to lead in revolt, needing their numbers but simply counting on the fact that when the time comes to rise, the slaves and the majority of the servants, generally unaware of the plan beforehand, will rise with them (73).

Johnston identifies this idealized republic as desirable and those who would implement it as honorable, yet she is wary of the overtly contradictory means by which they intend to achieve it. She characterizes the potential inherent in a multi-racial alliance among the servant classes in terms similar to those by which historian T. H. Breen compares the unique and common circumstances of the 1660 s and the 1890 s. In the latter half of the seventeenth century, Breen affirms, "it had been possible to overlook racial differences, a time when a common experience of desperate poverty and broken dreams brought some whites and blacks together. Such 
conditions were present in the American South during the 1890s, and it is not unlikely that they will appear again” (18). Laura F. Edwards offers some support for Breen's claim in her contention that the "burden of the Confederacy's war policies fell heavily on yeoman and poor white families, some of whom had opposed the war in the first place." Edwards writes: "Locating the problem in a political system that appeared to respond only to the interests of the wealthy, they resorted to extralegal activity. Even those from solid yeoman families often collaborated with propertyless whites, free blacks, and slaves, finding common ground in their opposition to the Confederacy's leaders and their policies" (188).

While Edwards's claims apply to the immediate postwar period and Breen's explicitly to the 1890 s, both establish that a cultural hierarchy in which race trumps class is neither inherent nor stable and must be maintained via complex social systems. If and when economic conditions for the poor and lower-middle classes become strained beyond a certain point, loyalties inevitably shift as do alliances and the resulting majorities. It is also important to note that class has never been "obliterated" as a means of social stratification, as some suggest, but that it is instead complicated by notions of race as a separate identifying category. Race, as Theodore W. Allen convincingly argues, is, in fact, a means of regulating both labor and capital: "it was only because 'race' consciousness superseded class-consciousness that the continental plantation bourgeoisie was able to achieve and maintain the degree of social control necessary for proceeding with capital accumulation on the basis of chattel bond-labor" (240). In such a culture, race and class can never be fully estranged.

The class-conscious alliance between white servants and enslaved people of color in Prisoners of Hope represents a missed, perhaps botched, opportunity. At once anticipating and reflecting on the Fusion politics of the 1890s, Johnston dramatizes the coalition in such a way as 
to critique its failure in complex ideological and methodological terms, disavowing the masculine violence of white supremacy as a useful political system and acknowledging its cultural presence even within significantly oppositional political movements. Originally conceived as the Farmer's Alliance in the 1880s, Populism surfaced as a "political force" in the mid-1890s (Perman 31). Populists seeking aggressive "federal intervention in the agricultural economy," according to Kantrowitz, "sought to break down the racial hierarchy that the Democrats had worked so hard to reinforce" ("Two Faces of Domination" 105). Joining forces with the largely black Republican party, these farmers engineered Fusion politics, a coalition which was considerably if briefly successful in many Southern states, including North Carolina and Louisiana (Perman 32). The rather quick and dramatic success of the Fusion movement inspired a backlash of Democratic manipulations, including voter intimidation and grandfather clauses. Ultimately, the defeat of Fusion politics occurred from within as well as from without, just as the republican revolution in Johnston's novel is unsuccessful in large part because it, too, self-destructs. In both cases, internal disagreements, perceptions of divergent interests, and an inability to overlook culturally constructed racial differences worked to weaken the movements from the inside. Many white Fusionists, while willing to collude with blacks, perhaps temporarily, in order to achieve common political and economic goals, were not immune to the hysterical racial and sexual rhetoric deployed by Southern white supremacists and Democrats in response to the specific challenge a Populist-Republican coalition posed for "the white man's republic" as Mary P. Ryan suggests (138).

Johnston capitalizes on the internal strife common to such "radical" movements that gallantly privilege class over race without fully admitting black or otherwise "raced" men into the fraternity when she dramatizes the internal collapse of Landless's republican revolution on 
just these terms. Godwyn's misguided plan to use a slave uprising to institute a republican government is obviously in jeopardy when Luiz Sebastian, the novel's one predominant "mulatto" character — and not coincidentally, its most vicious villain —warns Landless, the ascendant leader of the rebellion after Godwyn's murder, that he and other servants with knowledge of the insurrection are displeased with the plan: "The servants have no say in the matter; they are to follow like sheep where these others lead. The slaves are not even to know of it until the last moment. A handful of us who have white blood in our veins are let in on the secret, that we may incite the blacks when the time is come; but are we consulted?" (132). Sebastian's warning that "the insurrection may arrive, and the planters be put down, and next year may find us slaves still, with but a change of masters!” (132) is not heeded by Landless, who contends that Sebastian "must accept the conspiracy as it is. In liberating themselves, these men will of necessity free you even as they will free me, who am not, as you know, of their class. I shall take my chance, as I think you will take yours" (133).

Violent resistance, particularly divisive violent resistance, serves to fortify masculine white supremacy rather than weaken it either culturally or structurally, although it does so at great cost to the ideal democratic principles which white supremacy proposes to endorse. If Johnston's narrative is, as Joseph A. Young asserts, "a scripting of the racial/master discourse, a conscious fashioning of the racial other in the most influential domain, fictionality, in which the postbellum reconquest of the black other is achieved," Johnston's question remains: to what ends? (72). Johnston depicts Landless and his fellow white revolutionaries as loyal and their cause as generally honorable, yet she is ultimately critical of their methods, particularly the political idealism which blinds them to the social reality of their situation. That they intend to use a slave uprising to overthrow an oppressive regime and institute a republic is in and of itself 
contradictory. Their fatal mistake is that they continue to think of slaves as slaves, and this stems from their misconception (or conscious denial) of what a republican government entails. Johnston's depiction of the failed revolt and its splintering from within emphasizes that the oppressed are a stronger force to be reckoned with when they are banded together as a majority rather than divided amongst themselves. What Landless and his cohorts want to do is not necessarily displace the planter elite and upset the system entirely but to replace the planter elite with a new, differently oriented elite. Such a new leadership will still need to be able to manage the lower-class majority, and so oppression will not cease, despite glorified claims of revolution.

Landless optimistically wants to conflate race and class and anticipate future prospects accordingly, yet Sebastian recognizes a distinct racial divide among the lower classes. It is this glaring iniquity and Landless's unwillingness to either acknowledge or counteract this imbalance that leads Sebastian to form an alternate insurrectionary conspiracy-along with unscrupulous convicts "the Turk" and Roach, a red-haired implicitly Irish murderer-in which they will employ the Chickahominies and Ricahecrians, particularly brutal Native Americans, and "most of the slaves" in a veritable bloodbath set to end with the murder of all the planter men and the capture and concubinage of the white women (249-250).

This moment where her fictional uprising breaks in two is also the point at which Johnston most sharply breaks from the scant recorded facts of the Servants' Plot, a servile rebellion which (nearly) took place in Gloucester County, Virginia, along the Chesapeake Bay, in September of 1663. Robert Beverley, in The History and Present State of Virginia (1705), describes the 1663 rebellion as beginning when "the poor People becoming thereby very uneasie, their Murmurings were watch'd and fed, by several mutinous and rebellious Oliverian Soldiers, that were sent thither as Servants. These depending upon the discontented People of all sorts, 
form'd a villanous Plot to destroy their Masters, and afterwards to set up for themselves" (5960). Breen and Allen disagree about whether or not the plotters were indeed Cromwellian veterans, but agree that the conspiracy was discovered "the very Night before the design'd Execution ... by the Relenting of one of their Accomplices, whose Name was Birkenhead" (Beverley 60), and was therefore subverted. At least four of the conspiracy's suspected leaders were hanged, and nine "Laborers" were accused by a Gloucester court "of conspiring to arm 30 persons to overthrow the government of Virginia" (Breen 8). The servant who had betrayed his comrades reportedly received a pardon and $£ 200$, and 13 September, the day the uprising was to have taken place, was dedicated a commemorative holiday by local officials (Beverley 60$){ }^{26}$ Nonetheless, the aborted revolt terrified the planter classes, inspired increased vigilance and the passage of new laws curtailing the mobility of servants, and led to orders from the king that a fortress should be built to protect the governor and Jamestown from future insurrections (Breen 9).

In recreating the moment of revelation, Johnston has Landless stand in for Birkenhead. During a meeting of the principal conspirators at a tobacco house on Verney's plantation, they are discovered initially not because of an insider's betrayal but by "Mad Margery," an indigent white woman who lives on the plantation grounds and whose whims Patricia indulges when she is in the mood. Margery overhears and repeats to Patricia enough of the conversation among the "seven men in the tobacco house" for Patricia to deem it necessary to send Margery to the main house for help (228). Patricia, who remains behind to wait for Verney and Carew, hears more of the plan, including the group's intent to arm themselves, steal horses and boats, and return to the "this appointed place" where they will, thus assembled, entreat the slaves to join them in “oppos[ing] any force sent against us" (231). Discovering Patricia eavesdropping on their secret 
meeting, the men pull her into the tobacco house where Landless fights to protect her from the murderous rage of the others. Finally, "half a dozen blacks, the two overseers and Sir Charles Carew" arrive with pistols and swords, killing most of the conspirators in the ensuing struggle and taking Landless and Trail prisoner (235). What is most significant here is not Johnston's insertion of Patricia into the discovery scene but the element of dissent among the conspirators that her presence reveals. Landless and Havisham, a fellow Oliverian soldier lately arrived in the colonies, are the only two in the group who refuse to murder Patricia to save themselves and who see that such a cowardly act would be the undoing of their long-term goals.

It is important, for the plot of Johnston's novel and for her commentary on race and class relations in the nineteenth century as well as in the seventeenth, that Johnston draw upon an historical uprising that betrays itself from within, and that Patricia, the privileged white woman, be the reason Landless turns traitor. In this way, the active and willful consolidation of race over class appears to be a function of protection rather than dishonor, revealing a deeper sense of loyalty within the white political dissident who would abandon his cause in order to preserve a specific form of white masculine civilization in which Patricia will be protected at all costs. The novel's two parallel conflicts are inextricably joined when the insurgents threaten Patricia's life, and Landless must choose between the pursuit of his political ideals and his love for the master's daughter. Either way, Landless is sentenced to death in this moment. His betrayal, however, allows him to exchange his life for Patricia's and to make his death somehow meaningful. The price of his deliverance, and Patricia's, is his willful sacrifice of the black slaves and servants of color whose independence he had previously championed. The black slaves become scapegoats onto which the violence of class and political difference between white men is necessarily 
deflected in order to maintain a cultural hierarchy in which white women represent the threshold of civilization.

When the once comparatively united revolt splits in two and the second uprising, led by Luiz Sebastian, begins to take shape, terminology and allegiances abruptly shift and essentialist racial characteristics more or less suggested in the earlier parts of the novel become solidified. Landless and what is left of his men somewhat unexpectedly jump ship, choosing to fight with the planters rather than against them, as had been the initial plan, and effectively sacrificing their own revolution to defend those with whom they racially identify against those with whom they have shared oppression at the hands of the same, despite the fact that Landless still faces the gallows for his role in the aborted scheme. Whereas Landless and the idealized foundation of his now-defunct revolution maintain an air of nobility and honor, despite utter failure, Sebastian's contingency is conversely described as brutal and bloodthirsty. At the moment of revelation, the “dusky mass of slaves” whom Sebastian commands significantly "sway[s] forward with one low, deep, bestial growl" and the servants in the crowd form a "phalanx of villainous white faces - the dissolute, the convict, the refuse of the plantation" (262). This second wave of "raced" conspirators is far from honorable, even downright merciless in their indiscriminate slaughter of the planter families and all who would get in their way.

How we read Johnston's application of essentialist characteristics on the basis of both race and class affects how we interpret Johnston's commentary on the legitimacy of organized violent resistance and on the maintenance of a white supremacist culture. Johnston's apparently gratuitous use of common nineteenth-century discriminatory stereotypes does not necessarily indicate that she set out to write a novel, as Young claims, predating the "extremist forms" of the plantation tradition represented by Dixon's The Leopard's Spots and The Clansman and 
"designed to rationalize a return to white privilege after civil war and reconstruction, a reentitlement of whites that condones using exclusionary tactics (83). On the contrary, Johnston seems to assert that no one, is fundamentally entitled to anything if it is to be gotten or kept by violence and exclusion, including otherwise virtuous white men. Significantly, Johnston's white insurgents, despite a distinctly honorable purpose and leaders with pretty pedigrees, are no more successful in their idealized republican revolution than are the black slave rebels, driven to desperation by deepening structural inequalities. Both revolutions essentially undermine a democratic ideal, because, despite all the bloodshed, nothing is accomplished and nothing fundamentally changes. The wealthy white planters remain wealthy white planters, the insurgents are all either dead or exiled, and those servants and slaves who renounce their participation and escape the gallows remain in the same degraded positions that they occupied at the beginning of the novel.

Johnston's depiction of the Oliverians' "revolution" as the consolidation of race over class is a critical one, even as it reinforces brutal nineteenth-century racial stereotypes. Although he is characterized as opportunistic and cruel in his pursuit of freedom, Sebastian's reservations about the Oliverians' plot are retrospectively confirmed when Landless, after having been caught in the act of finalizing his plan and captured, devises a complex scheme to distinguish the (racially) "loyal" from the rebels among the "white and black, servant and slave, rustic, convict, Jew, Turk, Indian, mulatto, quadroon, coal black, [and] untamed African" (256). From "the motley crowd" Landless apparently points out "every man concerned in the plot discovered this morning," when in actuality he is calling forth those he knows not to have been involved in Sebastian's counter-plot, including slaves and servants not privy to Landless's own scheme (257). Landless has made a deal with Colonel Verney which ensures that Landless alone will "be 
the scapegoat for the rest of you" and that no one else will be punished in any way for their knowledge of the planned political revolt (262). Landless literally calls out by name those whom he believes can be counted on as loyal to fight with the whites against Sebastian's multi-racial cohort. Those he calls forth include Win-Grace Porringer, the Muggletonian, John Robert, “a Baptist preacher suffering under the Act of Uniformity," "then a Fifth Monarchy man, then a veteran of Cromwell's, then the plantation miller and the carpenter, then two more Oliverians, then more peasants" (258-259). In this way, political allegiance becomes racial allegiance and whiteness becomes equated with revolution.

While Johnston readily levels this critique against the white Oliverian plotters and the culture they represent, she, like Bouvé, is unable to realize a viable alternative including nonwhite leadership. Luiz Sebastian and his doubly rebellious contingency are characterized as racially indeterminate - mulatto, Turk, Irish — and therefore dangerous to any prospective or actual civilization. Neither African American and therefore ostensibly natural slaves, nor white and so ostensibly natural leaders, Sebastian, Trail, and Roach are inevitably on the outside of traditionally classed or raced identities and function as a specifically criminal element. Like the landed gentry, Landless and his soldiers show no loyalty to this excluded population in terms of the outcome of the revolt, and so inspire no loyalty in return. Realizing that there is a definitive hierarchy even within the resistance movement and that only the white elite will reap the potential benefits of the revolution, Sebastian decides to take his chances with the unruly Native Americans, at one point declaring that "they promise me a wigwam in their village in the Blue Mountains" (331). Despite the implied fragility of Sebastian's future with the Ricahecrians, he sees this as his only chance to be a part of a society, albeit a rebellious, victimized, and ostracized society. Sebastian's choice illustrates his limited options as well as those of the Native 
Americans. Both must remain or venture outside of white society in order to engage in any form of social mobility. Their fixed positions as outlaws and "savages" do not change even though Johnston makes clear that they are, in fact, driven to this savagery by the lack of social opportunities available to them.

This is the legacy of Landless's "noble" sacrifice to his race - the violent and purportedly revolutionary reenactment of race over class as the dominant organizing structure of American culture and politics. Johnston's collapsing of elements of two historical events - the lesserknown Servants' Plot and the widely-recognized Bacon's Rebellion of 1676 - into one fictional moment suggests that she anticipated the findings of later historians who more directly recognized the transition from indentured servitude to black slavery in the late seventeenth century. "Just as the overthrow of tenantry in the 1620 s had cleared the ground for the institution of chattel bond-servitude," Allen observes, “the defeat of Bacon's Rebellion cleared the way for the establishment of the system of lifetime hereditary chattel bond-servitude" (239). Furthermore, Breen aptly suggests that "the seventeenth-century Virginians exchanged white servants for Negro slaves, and in so doing, exchanged a fear of the 'giddy multitude' for a fear of slave rebellion" (17-18). This type of substitutive transition suggests that while relationships and positionality may evolve, the general nature of oppression and the fixed existence of oppressed groups remain fundamental to a white masculine social order both regulated and rejuvenated by revolutionary violence. In her dramatization of the complex dynamics among the conspirators of the uprisings, Johnston looks forward to "the subordination of class by 'race' at the beginning of the eighteenth century [as] the key to the emergence of the republic at the end of it," enacting the shift from class solidarity to race-based allegiance through the doubled act of revolution and revolt (Allen 240). Johnston seems to recognize as well the subsequent continuity between 
colonial revolts, the Revolution of 1776, and the American Civil War, as evidenced by her reinscription of nineteenth century racial codes onto the seventeenth century.

Johnston's ambivalence toward violent revolution as her nation's foundational legacy, evident in Prisoners of Hope, contributes to the innate futility of war in general and civil war in particular as a central theme in her later novels. Despite, and also because of, her devotion to her Confederate veteran father and to the cause for which he sacrificed so much, Johnston found herself at odds with popular white masculine narratives of the Southern past which glorified war and the noble sacrifices of dead and disabled soldiers. As Sarah E. Gardner has recently pointed out, "no matter how compelling postwar white southerners found the Confederate claim to independence, no matter how seductive the idea of secession, according to Johnston, the war qua war had been a disaster for the South" (10). Interestingly, as Elizabeth Young observes, Johnston has been compared to Ellen Glasgow and Mary Noailles Murfree as a Southern woman novelist who depicted actual Civil War battles in her fiction while other women writers of her generation like Grace King and Kate Chopin "filtered the war through the Creole Culture of Louisiana" (4). "Johnston," Gardner writes, "sought to break from the romantic, even celebratory nature of the southern Civil War novel and fought a three year battle with her editor over the iconoclastic content of her work" (190).

The work in question would become The Long Roll (1911), the first novel of Johnston's planned war trilogy on which she had been working since 1908. With this novel, Johnston followed in the footsteps of her literary predecessors, drawing "heavily on the dominant trope in Southern fiction - the myth of the Lost Cause," but she also veered from the expected course when she "expressed what she believed to be the futility of war." For Johnston, "these two aims . . reinforced each other while demonstrating the power of the Lost Cause myth over southern 
consciousness. No matter how noble, virtuous, and loyal to the Constitution were the Confederates, they were doomed to failure" (Gardner 196). The Long Roll met with harsh criticism from many Southerners, particularly those who objected to Johnston's characterization of Stonewall Jackson as profane and vulgar (Gardner 201), yet the second novel of her uncompleted trilogy, Cease Firing (1912) was more kindly received among critics and popular audiences in the South who found its "starkness" transcendent (Gardner 205). Johnston's struggle with her editor and with her audience over the nature of her Civil War novels is representative of Johnston's personal and literary negotiations of her own experiences with and memories of the war and its aftermath and the collective nostalgic Southern memories. Gardner's observations about Cease Firing and Johnston's dual consciousnesses, when considered in the context of Prisoners of Hope, point to a larger pattern of structural criticism in Johnston's work and suggest ways in which Johnston's seemingly conflicted representations of race, rebellion, and revolution might instead "reinforce each other" in her first novel as well.

Critique though it is, Prisoners of Hope stops short of recommending specific methods of social reform. Johnston leaves her characters hopelessly bound by proscribed social status. Even Landless, the novel's most internally developed character, is left to die at novel's end, suggesting that any claims to social status and potential social mobility are essentially false as long as one exists within culture without changing culture itself. The only glimmer of hope lies in the genuine romantic attachment between Landless and Patricia Verney, which resists the dominant masculine culture. This hope, too, is dashed, when white masculine civilization, in the form of Colonel Verney and Charles Carew, a cousin to whom Patricia is informally betrothed, encroaches upon their hideout in the cave above the forest. Strangely enough, although the Gloucester gentry and their search party appear just in time to rescue the lovers from the 
Ricahecrians, they, too, threaten the couple as they would also take Landless's life and, in effect, capture Patricia. Patricia, although ostensibly rescued, is actually forced back into the role of "republican mother" by both her father and her lover, in the tradition of Reconstruction-era conceptions of nationhood and of the white woman as Columbia, an icon which Shirley Samuels describes as "a national housekeeper who assists with domesticity and racial violence" and who "guards the entrance to the national home, protecting and disbarring" (44).

As for Landless, he remains bound for the gallows at Jamestown despite the great personal risk he has assumed in doggedly pursuing Patricia's captors through the wilderness even when Verney and Carew could or would not. Insisting that they are "not ungrateful" and that their "hands are tied," the best Verney can offer Landless is his "choice of deaths" (369371). Verney will leave Landless alone and wounded in the wilderness with winter approaching, because there is no chance of pardon and no place for Landless, a convict, an insurrectionist, and worst of all, lover of his daughter, in their supposedly civilized settlement. Having valiantly defended the white patriarchy, in the form of Verney Manor, and thereby proven his whiteness, Landless is no longer fit to resume the role of servant. However, as both a political rebel and one who has counted himself among the oppressed servant class, Landless can neither be integrated into the world of the white elite nor accepted into the Verney family as Patricia's husband. Both Verney and Johnston must make an example of him; otherwise they risk advocating violent insurrection as a means of social mobility. Worse, they risk suggesting that social designations like race and class are not fixed or permanent but can be reasonably transcended.

The implication in Landless's presumed death at novel's end is twofold. First, in order to effect true revolution, one must not only breach but ultimately break down the structure of an incongruent and oppressive society, and, second, this can only be accomplished by cultural 
rejection of a masculine social order and not by the violent reassertion of white supremacy. The novel presents the idea that US culture is static if not stagnant but never stable. Biographer C. Ronald Cella remarks of Prisoners of Hope that “one's impression is that the Cavalier aristocracy is an artificial civilization, genteel but fragile, in constant danger from the props which hold it up" (35-36). Such a characterization is equally applicable to the former Confederacy as well as to the contrived social and legal hierarchy of the late nineteenth century. In fact, Cella's observation is necessarily relevant to any civilization built upon race or classbased hierarchies and supposedly empirical systems of democracy. When the masses are oppressed there is discontent, and where there is discontent there is a constant threat to the ruling elite. Like Luiz Sebastian, who fears a mere "change of masters" will occur in the absence of true revolution, Johnston's novel etches out a complex social structure in which masculine civilization is always artificial and always built upon a volatile and unstable foundation of contingency and oppression which must be maintained by force in order to remain viable.

Johnston's internal doubling of the event as she imagines it, her revisionist splitting of one uprising into two parts, essentially two revolts, is symbolic of the split between ideal democracy and functional, structural, masculine white supremacy. Such a grossly incongruent social structure maintains along with a tremulous sense of false stability a complementary and ubiquitous riotous presence. In rendering violent resistance to governing authority ultimately futile, Johnston suggests that insurrection will always fail to effect meaningful social change because the riotous presence exists even within the insurrectionary movement and will inevitably carry over into the social fabric of the culture it portends. As with Bouvé's Their Shadows Before, early reviewers of Johnston's first novel were both cautious and torn in their responses to her unique narrative approach to contemporary cultural criticism. One anonymous critic for The 
Literary World remarked in October of 1898 that "the narrative in Prisoners of Hope is so interesting that the reader is disappointed at its "melancholy and inconclusive finale,"” while another perhaps more prescient reviewer for The Critic commented in December that "the conclusion reveals the 'full scope of the author's talent.",28

\section{"I will carry the war into Africa": Pauline Hopkins's Winona ${ }^{29}$}

As both Bouvé's and Johnston's narratives illustrate, women of color were virtually excluded from white narratives of lynching and racial violence that triangulated the relationships between white men, black men, and white women in a fraught battle over the contested terrain of white women's bodies. These post-Reconstruction era narratives, penned by white women as well as by white men, depended on the silencing and subjugation of black women, building on a pattern established during the Civil War era, when popular literature argued instead that "slave women's very identity was founded on their closeness to whites," particularly their masters, and they appeared primarily as the nurturing figures of "Dinah" or "Mammy," according to Alice Fahs (189). Pauline Hopkins's depiction of her title character, Winona, as a cross-dresser, a prison nurse, and a soldier, although altered to adhere to the historical record of "Bleeding Kansas" and Pottawatomie rather than to the events of the Civil War, highlights the absence of women of color and mulattas in particular in Civil War literature depicting white women in new roles subverting traditional gender binaries. As Samuels argues, the "near invisibility [of African American women] in the published accounts of the heroism of cross-dressing soldiers and the long-suffering patience of Civil War nurses found partial compensation in the narratives published later" by authors like Hopkins and Frances Harper, who "retell the story of the war in 
neogothic narratives anticipating those produced later in the twentieth century by Toni Morrison and Gayl Jones" (94).

By rewriting these feminized narrative histories of the Civil War in terms of black female subjectivity and the traversal of race and gender boundaries by women of color, Hopkins reclaims for her mulatta character and for post-Reconstruction women of color a cross-racial history of gender subversion and active resistance in defiance of overtly sexualized historical stereotypes. The mulatta, in particular, was absent in Confederate literature which "worked to mystify the power relations of slavery by maintaining the fiction that no such sexual or social relations existed" between men and women of different races (Fahs 190). Conversely, in Northern Civil War literature mulatta women served as "sexualized boundary markers" (Fahs 190). These narratives contributed to the evolution of later post-Reconstruction ideas about "true womanhood" as defined "by qualities that were increasingly raced white," according to Teresa C. Zackodnik, and dependent on images of "black fallen womanhood" (78-80). Standard white supremacist narratives constructed race in terms of gender and gender in terms of race, leaving women of color doubly constrained by racialized and sexualized stereotypes depicting black women as licentious, promiscuous, and ultimately responsible for "the ostensible 'immorality of the black race"' (Paula Giddings, qtd. in Zackodnik 80).

In Winona, the lawlessness of prewar frontier Kansas and Missouri stands in for the chaos of the post-Reconstruction nation, wherein Pauline Hopkins reenvisions ostensibly fixed race and gender binaries by inserting Winona into this specific historical moment and constructing her as a veritable savior of the races by virtue of her ability to transgress race and gender boundaries. Winona, therefore, is not expectedly tragic but representative of the collective inability of Hopkins's postbellum audiences, and of her white female contemporaries 
like Bouvé and Johnston, to reconcile the nation's racially and politically fractured past with the equalizing promises of Reconstruction. Winona's active support of organized anti-slavery resistance and her direct involvement in the violent conflict spearheaded by white revolutionary John Brown reposition women, especially women of color, explicitly as victims of white supremacist violence and simultaneously as agents of concentrated struggle against white supremacy and the disorder it maintains.

Hopkins's creation of a mulatta character who does not conform to type effects a decentering of the tragic mulatta tradition, because Winona is rendered a political agent, an active participant in the anti-slavery agitation of her novel and therefore an active participant in history itself. Hanna Wallinger has argued that Winona enacts "a decentering of the plot of the tragic mulatta," achieved through the removal of Winona from the role of protagonist: "Winona is not really the main character in the story. She does not have to die, and her tragedy is avoided; the political action of antislavery agitation is seen to be more important" (192). In Wallinger's formulation, Winona's very survival and refusal to succumb to tragedy causes her to be eclipsed by the historical memory of white masculine violence, suggesting that the mulatta character is most culturally valuable when she is trapped between multiple and fundamentally irreconcilable racial identities. This conclusion misses the fact that Winona, doubly constrained by a masculine white supremacist culture of oppression, is an even more transcendent figure as a woman of color with a reasonable measure of control over her own destiny.

Combining elements of what Susan Gillman has termed the "two basic, relational plots" of the post-Emancipation maternal melodrama: "the maternal-familial plot of reuniting the dispersed family and, alternately, the maternal-passing plot of the invisible dispersal of 'black blood' into the national mainstream," Winona places the family, and thus the feminine, at the 
center of masculine confrontations over race and power (36). In the novel's opening scenes, Winona and Judah are children yet, living a peaceful, almost utopian, life as brother and sister on a small island near Lake Erie until the murder of their father, White Eagle, by Colonel Titus and overseer Bill Thomson. Winona is the biological child of White Eagle, a white man living as a Senaca [sic], and an escaped slave woman who adopted Judah as her own after his mother died during their flight north. Kidnapped and remanded into slavery by Titus and Thomson, Judah and Winona are removed to Titus's Kansas City plantation. Here Winona finds herself thrust into a world of masculine violence by border ruffians who represent the spread of slavery and the destruction of families, including their own. Subsequently, as members of Brown's camp, Winona, Judah, and Warren literally engage in battle against the proslavery forces represented by Titus and Thomson. The laws of the land turn family upon family in mortal violence. Hopkins demonstrates, through the complex genealogical mystery of Winona and Winona's central relationship to the dominant conflict both of nation and of family, that the national conflict is also explicitly divisive on fundamental personal levels. Winona is Hopkins's novelistic protest against dominant postbellum white supremacist narratives that situate slavery securely in the nation's public-political past, denying the genealogical legacy of institutionalized white supremacy and its consequences for future generations and for women of color in particular.

Hopkins connects this public, masculine violence with the more private violence women and children endured. While Hopkins does not specifically dramatize in Winona the Margaret Garner case which was contemporary to the action of her novel, Hopkins's emphasis on the destruction of families, black and white, through legal practices like the Fugitive Slave Law which explicitly enables Titus's capture of Judah and Winona, evokes the memory of one family's unforgettable plight. One of the most dramatic instances of black resistance to slavery 
and of the national conflict over the Fugitive Slave Law began in January 1856 with the flight of the Garner family from their captivity on a northern Kentucky plantation, a mere five months before Brown's men would execute proslavery rivals at Pottawatomie. On the morning of 28 January 1856, Margaret Garner, a pregnant twenty-two year old mother of four, facing capture and reenslavement, "nearly decapitated" her two-year-old daughter Mary with a butcher knife inside a surrounded Cincinnati home (Weisenburger 72-75). Garner's desperate attempt to prevent her other young children from being returned to slavery was interrupted by slave catchers who "burst in and subdued her" (5). As Steven Weisenburger documents in Modern Medea: A Family Story of Slavery and Child-Murder from the Old South, Margaret Garner's trial raised key questions concerning the constitutionality of the 1850 Fugitive Slave Act and integral issues of states' rights.

Indictable under Ohio statutes for the murder of her daughter, Margaret Garner's conflicting legal identities as property to be returned to her owner and as culpable actor ordered to stand trial for her child-murder epitomized the legal contradictions inherent in both the Fugitive Slave Law and the dehumanizing institution of slavery itself. Weisenburger locates in the rhetoric "of fraternal strife" and the sectional "differences over Margaret Garner's case the roots of civil war" (6). For Garner, who was returned to slavery after much legal wrangling, the issue was clearly less national than experiential, even as it was symbolic for many. Sometime during the night of Friday, 7 March 1856, a steamboat bound for New Orleans, on which Garner was a captive passenger, collided with another boat. In the melee that followed, Garner was either thrown or jumped into the icy Ohio River with her ten-month-old daughter Cilla in her arms. While Garner was rescued, Cilla drowned, prompting speculation that Garner had tried to drown them both, again preferring her own death and the death of her child to a life of bondage 
(221-225). As Weisenburger rightly concludes, “Margaret Garner's infanticide spotlighted the plight of women slaves and symbolized slavery's awful, violent power over and within slave families - issues once at the very heart of anti- and proslavery arguments but waylaid for generations in the grand narratives about slavery's constitutional challenges leading to disunion" (8).

Garner's story is significant, because it places Winona in dialogue not only with antebellum narratives of spectacular fugitive slave rescues but also with earlier "preEmancipation race melodramas (by, e.g. Harriet Beecher Stowe and William Wells Brown), which are driven by the urgency of the issue of abolition" (Gillman 36). Stowe dramatizes Garner's case in Dred: A Tale of the Great Dismal Swamp (1856), published later the same year, through the character of Cora Gordon, Tom and Nina Gordon's half sister. Like Winona, Cora Gordon is legally free, having been taken to Ohio, specifically Cincinnati, and emancipated by her former owner, who then married her. After her husband's death, Tom contrives to defraud Cora and her two legally free children of the estate left them by her husband and to that end has Cora and her children remanded into slavery (Stowe 437). With a nod to Margaret Garner, Stowe has Cora Gordon murder her two children the day before she is to be "sent off in a coffle" (438). Unlike the Garners, whose silence reflected the declination of insurrectionist slave rebels Nat Turner and Gabriel Prosser "to acknowledge their revolutionary deeds as actionable 'crimes' because they had already rejected as tyrannical the entire legal machinery that whites had used first to oppress and then to indict them" (Weisenburger 77), Cora Gordon stands up in court and declares loudly that she was "not excited" and "not in a frenzy" but that she killed her children because she "loved them so well that I was willing to give up my soul to save theirs!" (Stowe 439). 
Winona's complex genealogical mystery, wherein Winona is finally revealed to be the daughter of White Eagle and legitimate heir to the Carlingford estate, points to the intimate family politics of enslaved women of color and their white masters. Garner's sensational childmurder, for example, provoked speculation that little Mary's father was actually Margaret's owner, John Gaines, a conclusion which, as Weisenburger suggests, would mean that Garner “destroyed her master's property with the same knife stroke that destroyed his progeny" (77-78). Viewed in this way, Weisenburger notes, "Margaret's child-murder was a masterstroke of rebellion against the whole patriarchal system of American slavery," an observation which was certainly not lost on Hopkins or on Stowe (78). As a crucial event in a then-undeclared war for abolition and against the spread of slavery virtually mandated by the 1850 Fugitive Slave Act, Margaret Garner's infanticide literally connected intimate family affairs and blood ties with the inconsistencies of fraught national politics.

In Winona, women are victims of white supremacist violence and are, therefore, just as likely to be involved (and justified) in the perpetuation of violent resistance, and families are positioned as at the center of public cultures of resistance. Winona's multiple instances of passing in the novel, both conscious and unconscious, effect a rhetoric of reconciliation, not necessarily in terms of nation but in terms of family and personal relationships across transmutable racial lines. Significantly, Winona's most dramatic act of passing is one in which she crosses the gender divide as Allen Pinks, a mulatto youth who nurses Maxwell through his illness, the result of his attempted lynching by Thomson and a white mob (383-386). Passing as a boy allows Winona to insert herself into the intertwined masculine narratives of legal and extralegal violence, yet even in disguise Winona/Allen retains inherently feminine characteristics. Maxwell's description of Winona/Allen as "the prettiest specimen of boyhood he 
had ever met" with "delicate brown features" and hair "like velvet" allows Winona to retain her identity even while passing and reveals the complementary race and gender barriers which necessitate her act of passing as both contrived and absurd (388). Interestingly, Winona darkens her skin to pass as Allen, an act designed both to conceal her feminine beauty, which is consequently defined in terms of her light skin, and to render her features more masculine by making them darker.

Winona's dual reversal of passing traditions undercuts white supremacist constructions of racialized masculinity and femininity at the same time as it plays into predominant conceptions of idealized womanhood. As Zackodnik has argued of Hopkins's novels, "the mulatta, far from being tragic, becomes a subversive character who signifies on the color line by effectively passing for a "true woman"' in terms of nineteenth century discourses of pious, pure, domestic white womanhood (76-78). This is not to say that Winona ever passes as white; she does not. Instead, Winona, maintains the desirable raced-white feminine characteristics of "true womanhood" even while she darkens her skin and engages in decidedly masculine behavior. Winona, who commands the "homeguard" made up of the women of John Brown's camp, every one of whom "carried a rifle in her hand and was prepared to use it," effectively represents the marriage of feminine restraint and masculine power in a positive and decidedly fluid reinterpretation of masculinized black women and accordingly feminized black men (409).

As the multiple instances of passing in the novel illustrate, the policing of the color line "takes place on both sides of the color line, underscoring that the mulatta and passing challenge both 'blackness' and 'whiteness"' and implicitly raced constructions of gender binaries (Zackodnik xiv). Maxwell also symbolically crosses the color line, if inadvertently, when he is nearly lynched by Thomson and the white mob (Hopkins 367). Bound to a stake with a fire 
blazing at his feet, Maxwell is described in the hyper-masculinized terms applied to black men accused of raping white women in the late nineteenth century, yet his whiteness is also exaggerated: "His shirt was open at the throat, showing the ivory firmness of his chest and the beating pulse in the white brawn" (370). As Martha H. Patterson has argued, Maxwell "is made here a physically disempowered Christ. Judah now takes on the paternal role" (450) when he and John Brown, with Winona's help, rescue Maxwell from his prison and Judah must carry Maxwell "in his strong arms . . out to the waiting vehicle" (Hopkins 396). These instances of traditional role reversal across race and gender lines are consistent throughout the novel and support Hazel V. Carby's assertion that "the tale concentrated on organized and individual acts of resistance and self-defense against oppression" (155).

Hopkins's act of swapping Maxwell's expected role as rescuer for Judah's role as lynch victim emphasizes individual behavior as situational and dependent on culture and context, a strategic move which heightens expectations for both in the war against structural and ingrained practices of white supremacy. When Wallinger writes that "apart from Judah, the followers of John Brown and the fighters in his camp are white, and thus the agency and responsibility for what happens is placed on them," she suggests that Judah "is denied access to power because of his race" (191). This is an assumption and a problematic one at that, not least of all because it overlooks the vital role women play within the camp as combat support. It also assumes that whites like Brown have an innate ability to usurp power from black men, not just on a cultural level but on a spiritual and emotional level as well. Judah is powerful; so powerful, in fact, that he must be restrained by Winona and Maxwell, as Patterson notes, to keep him from firing the fatal shot into Thomson. That "he needs such restraint . . . invokes the very racist rationale for Jim Crow culture [Hopkins] seeks to refute," Patterson argues (451). Yet the fact that Judah 
ultimately proves himself capable of the requisite self-possession again reverses the stereotype. The agency assigned to whites in Winona is not necessarily a gift, as Brown's inevitable death portends, and it does not necessarily imply a corresponding lack of agency for blacks or for black men in particular.

Accordingly, Hopkins gives credence to arguments for a more pacifistic and faith-based resistance at the same time as she advocates for violence and action when necessary. Winona combines faith and violence in the tradition of David Walker's Appeal (1829) or Martin Delany's Blake: Or, The Huts of America (1859-1862), asserting that slavery and oppression are the true affronts to God rather than violence in defense of one's soul (or the souls of one's children). The real ethical code, as combatant Ebeneezer Maybee explains, is to "trust in the Lord and keep yer powder dry, as our friend Brown'd say," or, in other words, to work toward a peaceful resolution but to always be prepared for a fight (401). As Patterson notes, Hopkins carefully differentiates between personal vengeance of the kind Judah would enact in killing Thomson and the disinterested "altruistic wrath" of Brown's murder of the five proslavery Rangers (451). Although she refuses to consider Brown a fanatic, presenting his violence as sanctioned by God, Hopkins's presentation of violent resistance remains problematic. Winona, Judah, Maxwell, Maybee and the novel's other antislavery protagonists are presented as combatants in an undeclared war, and therefore justified in their actions; however, war in itself is not an ideal or even desirable state of affairs. Rather, any violence or need for violence is a lamentable evil, and only those who would use it minimally and most effectively toward an end to the conflict approach righteousness.

If the shedding of fraternal blood is the necessary result of arbitrary social systems that would insist upon separating families along capricious racial lines, as Hopkins suggests, then 
blood is also the key to national and familial reunification. John Brown's ultimate sacrifice at Harpers Ferry and his gallows declaration that "the crimes of this guilty land: will never be purged away; but with blood" (qtd. in Quarles 124) constitute a call not only for the shedding of blood but specifically for the blood of those who could or would claim white privilege at the expense of others. Nudelman describes Brown's gallows declaration as “one of the most powerful, and incendiary, arguments made by antislavery radicals in the prewar years: if white Americans did not repent, and reform, they would suffer retributive violence at the hands of black insurgents, or of an angry God acting on behalf of the enslaved" (9). As Hopkins's postReconstruction recreation of Brown's martyrdom indicates, the tremendous loss of life and terrible bloodshed of the Civil War is in vain if racial discord continues to tear apart families and to demand retribution by and on behalf of the oppressed. Blood, as Hopkins insists, can be both divisive and healing, and it is when blood ties ultimately bring together combatants on either side of the racial divide that it has the potential not only to expose the artificiality and incongruence of such cultural rifts but, as in the maternal melodrama, to begin the process of healing deep wounds.

Hopkins renders Brown representative of his environment, particularly of the national struggle against slavery and of the underlying and incongruent principles on which it thrived. In Winona, as in the other two novels of this chapter, it takes an outsider (either an Englishman, a "savage," or a pre-cultural child) to recognize the outstanding disjunctions between American cultural and structural principles and the ideal democracy they purport to proclaim. Warren Maxwell, the English protagonist, comes to the conclusion that he is "in the heart of a hostile country although supposed to advocate and champion the most advanced ideas of liberty and human rights. What a travesty the American government was on the noblest principles! Bah!" 
(381). Maxwell is just discovering what African Americans have long-since recognized, according to Quarles: "The whole pattern of black-white relations in antebellum America was to blacks a form of violence, often concealed under familiar, institutional forms, but pervasive and ever on the march" (35). Like Hopkins, Scott John Hammond connects John Brown's characteristic personal idiosyncrasies and seeming inconsistencies, particularly his controversial actions at Pottawatomie Creek, with his cultural and sociopolitical environment. According to Hammond, "Brown's fractured self is an embodiment of the tangled forces of light and darkness that grappled for the republic's soul; his character and actions demonstrate this, and in doing so, make him no different from the ruptured essence of our collective political self-consciousness. The Pottawatomie slaughter represents a symptom of the deeper malady, just as the abuse of any slave by an overseer represents the same type of symptomatic manifestation" (63).

Hopkins's choice of Pottawatomie over Harpers Ferry is indicative of her assessment of post-Reconstruction America as in the throes of an undeclared race war, a story, unlike Harpers Ferry, which everyone does not already know. John Brown's martyrdom at Harpers Ferry has come to be linked to the Civil War, significantly a declared war with identifiable battles, wins, and losses and fought over a definitive period of time, and, just as significantly, is apparently representative of the Union's unequivocally righteous victory. His actions at Pottawatomie are more comparable to the undeclared war being fought during the post-Reconstruction period. Lynching, disfranchisement, segregation, wage slavery, and convict leasing, to name only a few, were, like the attempted capture of escaped slaves on free soil or warrants sworn out against Brown and his men by the proslavery contingency in Kansas, ostensibly legal practices functioning within the bounds of peacetime laws and codes of behavior. The righteousness of resistance in post-Reconstruction America, after the Civil War has been fought and ended and 
slavery has been abolished, after African Americans and former slaves have been formally granted by constitutional amendments citizenship, due process, and, for black men at least, access to the franchise, is rendered questionable, ambiguous, uncertain, by the dominant masculine culture, which chooses to insist upon images of order where chaos actually reigns. An antislavery martyr like Brown is ostensibly no longer needed, and those who would continue his work after emancipation are not celebrated but relegated to insurgent status, as were Turner, Prosser, Vesey, and other slave rebels before history vindicated their sacrifices.

Winona bridges the historical space between the prewar frontier, where her character is literally situated, and the more conceptual than geographical postwar frontier of Hopkins's postReconstruction present. Carby's observation of Hopkins's first novel, Contending Forces, that the "actions and destinies of Hopkins's characters were carefully related to the condition and actions of their ancestors" and that "the consequences of events initiated at some specific moment in history constituted a significant aspect of Hopkins's fictional strategy" is equally applicable to Winona (128). Presenting a more subversive view of the Pottawatomie shootings as one incident within the indeterminate span of a "holy war," Hopkins more directly links the chaotic violence of postbellum America to early manifestations of the then-undeclared Civil War in frontier Kansas (419). Quarles observes of Brown's role in the Pottawatomie killings that the “murders would constitute a stain on Brown's career, particularly when his own grim role in the incident became fully substantiated some years afterward," yet Quarles goes on to emphasize that Brown's black supporters “viewed the incident from a wider perspective of aberrant behavior in their country, from a greater familiarity with the climate of violence, both legitimate and extra-legal, in the land of their birth" (35). The Fugitive Slave Law, passed in 1850, had 
indeed sparked an undeclared war of sorts to be fought out on a national scale in the years leading up to Brown's foray into Kansas.

Hopkins's contemporary Du Bois also places Brown's actions at Pottawatomie in the context of an ongoing struggle, noting that the murders of five proslavery "Rangers" were a direct response to the sacking of Lawrence and to the obvious failure of more passive forms of resistance. "Two thousand Missourians," Du Bois writes in his biography of Brown, "surrounded Lawrence and while the hesitating free state men were striving to keep the peace, sacked and half burned the town on the day before Brooks broke Sumner's head in the Senate chamber, for telling the truth about Kansas" (66). Du Bois's description of Brown's reaction is worth quoting at length:

The deed was done. Kansas was a slave territory. The free state program had been repudiated by the United States government and had broken like a reed before the assaults of the pro-slavery party. ... Then suddenly there came the flash of an awful stroke - a deed of retaliation from the free state side so bloody, relentless and cruel that it sent a shudder through all Kansas and Missouri, and aroused the nation. In one black night, John Brown, four of his sons, a son-inlaw, and two others, the chosen executors of the boldest free state leaders, seized and killed five of the worst border ruffians who were harrying the free state settlers.... The rank and file of the free state men themselves recoiled at first in consternation and loudly, then faintly, disclaimed the deed. Suddenly, they saw and laid the lie aside, and seized their Sharps rifles. (66)

Rather than a merciless criminal act, Du Bois sees the Pottawatomie killings as a much-needed and ultimately inspirational show of violence in response to violence. Paul Finkelman also 
evokes the chaos and lawlessness of a territory up for grabs when he notes that in "Kansas the sword and the gun, not the ballot and the printing press, had become the method of determining what kind of government the territory and future state would have" (xxv). Du Bois, however, connects the disorder in Kansas to contemporary goings-on at Washington, rendering the nation rather than just the territory the location of an ongoing and undeclared war.

Hopkins does with her fictional recreation in Winona what Du Bois does more directly and with a more aggressive political agenda. That is, she equates the lawlessness and chaos of the American frontier with the lawlessness and chaos at the root of American politics and culture. Slavery, Jim Crow, lynching, fratricide, family, race, gender - all of these things meet on the frontier where they are, as in the colonial period of which Johnston writes, still undeclared elements in an ongoing battle. Ammons convincingly argues that Winona's "efforts to recuperate right-minded white men, including the abolitionist John Brown, and thus write into its own revolutionary plot representatives of the power structure who have denounced that structure radically conflicts with its reliance on the western, by definition an imperialist form" (216). Ammons further suggests that the western form of Winona "cannot be reconciled with the slave narrative or to the racialized protest novel, the other two genres most important to Hopkins in Winona" and that this situates Winona as "trapped into profound contradiction by its generic participation in the western" (215-216). However, this "profound contradiction," the incongruence of novelistic forms and of the roles and characters necessary to complete their stories, seems to be, rather than an indication of Hopkins's limitations, precisely her point. Or, in other words, Hopkins's reconfiguration of these generic limitations situate Winona both as accurate representation of a chaotic culture and as transformative force, protesting that culture by manipulating the forms by which it purports to bind Hopkins and her history. 
Winona is a transformative force, as she represents a multiracial community that emerges from within the chaos of white supremacy, from within the frontier of American culture. Her character suggests that race is more than black and white, and that the politics of resistance involve more than debates for or against violence. On the frontier, aligned with John Brown, representative of both the white power structure itself and of internal resistance to the white power structure, Winona inserts herself into the white masculine rhetoric of revolution. It is here, on the frontier - or in a colonial wilderness, or in the fields of Southampton County — that revolution remains possible, that reconfigurations of race and class and gender are possible, that a renegotiation of the structures that necessitate the violence of control and the complementary violence of resistance is possible. In Prisoners of Hope, Johnston suggests that revolution is really just white men fighting with other white men for political control. In Their Shadows Before, Bouvé posits revolution as a battle between the races, although she is unable to imagine what it might look like if black insurrection succeeds. Hopkins, then, avoids these binary definitions and embraces the chaos of the frontier, because the frontier is everywhere and everywhere is the frontier.

\section{A Violent Past in the Present}

The ease with which these authors translate the cultural politics of the present into events of the past reveals an overarching continuity among seemingly distinct historical periods and corresponding systems of oppression. Bouvé, Johnston, and Hopkins blur the supposedly fixed temporal boundaries so painstakingly established by white male authors like Tourgée and Dixon by exploring the peripheral causes and effects of the historical events. These novels consider the roles of historically non-central actors, specifically white women, women and men of color, and 
children, fundamental to the historical experience and memory of these particular events and their contexts. They also consider the roles of historically central white men from different angles, therein revealing the historical privileges essential to the maintenance of collective cultural memories. In so doing, Bouvé, Johnston, and Hopkins explore continuities of experience across ostensible temporal and legal divides and between and among members of apparently fixed identity groups. While all three authors represent specific instances of violent resistance within the historical context of their novels, they also represent less pronounced and less obvious forms of cultural noncompliance within the everyday social and personal lives of their characters. The specific historical contexts change over time, but the moments of personal triumph and despair, as well as the need for individual struggle against incongruent social systems, remain consistent and consistently relevant to post-Reconstruction era audiences. This is not to say that human experience is ahistorical but to illuminate, as these writers do in blurring the politics of slavery and emancipation, the artificial and deceptive boundaries between defined historical periods and the corresponding claims to actual political and social change.

Together, these authors significantly illuminate the accumulative effect of resistant acts, whether that effect is to reinforce the white power structure through the consolidation of class over race, to link the struggle for freedom during slavery with the struggle for citizenship amid the violence of Jim Crow, or to suggest that chaos and war are the natural state of affairs in a white supremacist culture, even when the war is undeclared. Hopkins also warns us not to be fooled by the rhetoric of "noble" sacrifice, especially when that sacrifice is in service of one's race, as is Landless's in Prisoners of Hope or Nathaniel's in Their Shadows Before, because nobility suggests a clear division between right and wrong. In her discussion of Contending Forces, Laura Doyle emphasizes Hopkins's complication of the term noble, "which exposes a 
universalist nativism's fundamental incoherence within an Atlantic history of rape and diaspora" (380). It is useful to think of Doyle's commentary in terms of Bouvé's and Johnston's universalist appeals to "noble" revolutionary violence and in terms of Hopkins's resistance to such appeals in Winona. Bouvé's novel reveals its own naiveté in its suggestion that violent revolution can, eventually, lead to lasting peace, while Johnston's novel highlights the futility of violence or resistance of any kind, wherein she overlooks the plight of the truly oppressed, like Bouvé's Nathaniel. Hopkins, however, establishes that violence is more than a potentially necessary form of resistance, that it is the norm within a social system of culturally created and inherently unstable racial hierarchies. For her protagonists, who are victims of culturally sanctioned violence on a daily basis, it is the more pacifistic and faith-based means of resistance that are essentially futile and, moreover, linked to the tainted teachings of the white slaveholding elite.

Notes to Chapter 3

${ }^{19}$ From Grant Allen's “Plain Words on the Woman Question" (1889), quoted in Anna Julia Cooper's A Voice From the South (http://docsouth.unc.edu/church/cooper/cooper.html), p. 67. "As a body we 'Advanced men' are, I think, prepared to reconsider, and to reconsider fundamentally, without prejudice or misconception, the entire question of the relation betwen [sic] the sexes. We are ready to make any modifications in those relations which will satisfy the woman's just aspiration for personal independence, for intellectual and moral development, for physical culture, for political activity, and for a voice in the arrangement of her own affairs, both domestic and national."

${ }^{20}$ Special thanks to Professor Eric Gardner of Saginaw Valley State University for his generous assistance in locating and interpreting archival and genealogical research on the relatively obscure Pauline Bouvé. Primarily known as an author of children's literature and as a newspaper correspondent, Bouvé authored several collections of short stories, including American Heroes and Heroines (1905), Lamp-Light Tales and Other Stories (1922), and Tales of the Mayflower Children (1927). She was also a frequent contributor to Gunton's Magazine (1898-1904), Lippincott's Monthly Magazine (1886-1915), The Youth's Companion (1827-1929), New England Magazine (1886- 
1917), and to the Boston Evening Transcript (1830-1941) and the Boston Globe (1872-1979), among others. See also Who Was Who In America Volume 1 (1897-1942), p. 120, for a partial list of Bouvé's publications and for biographical details. For more information about Anne Cabell's family, see Alexander Brown's The Cabells and Their Kin (1895).

${ }^{21}$ Bouvé's father-in-law, Thomas Tracy Bouvé, Sr., once served on the Committee of Vigilance and Safety formed at the notable Faneuil Hall by some of Boston's leading abolitionists in defiance of the 1850 Fugitive Slave Law ("Rocking the Old Cradle of Liberty" 167).

${ }^{22}$ Geffert cites Richard J. Hinton, John Brown and His Men, With Some Account of the Roads They Traveled to Reach Harper's Ferry [sic] (New York: Funk and Wagnalls, 1894), pgs. 26 and 31, as her source for this information (n. 2, p. 38).

${ }^{23}$ See also Life and Letters of John Brown, Liberator of Kansas, and Martyr of Virginia. Ed. Franklin B. Sanborn. 1885. Rprt. New York: Negro Universities Press, 1969.

${ }^{24}$ Most Southerners at the time of Turner's revolt refused to believe that blacks and slaves possessed either the industry or the intelligence to organize and implement active resistance. Nor did slaveholders acknowledge that their chattel had reason or provocation to commit such brutal acts against their self-proclaimed masters. Grimsted documents the occurrence of the first Virginia anti-abolition riot "shortly after Nat Turner's revolt, seemingly an attempt to soften that event's terror by connecting outside instigators with the homegrown reality" (125). Northerner and abolitionist William Lloyd Garrison, who was personally suspected of rousing slaves to revolt through the pages of his anti-slavery paper The Liberator (1831-1866), denied charges of inciting the rebellion, claiming Christian pacifism, according to historian Louis P. Masur (152). According to Masur, the "work of liberation and retribution begun by Turner in Virginia opened a national debate that fueled regional rivalries and triggered a wide-ranging discussion over what to do about slavery in Virginia" (149). Southerners, for the most part, chose to stand by their original accusations against incendiary writings like those published in Garrison's Liberator and in David Walker's recently distributed Appeal (1829), but the physical manifestation of the revolutionary spirit of these texts in Turner's revolt inspired Virginians, including the state's governor John Floyd, to explore methods of gradual emancipation in the state of Virginia.

${ }^{25}$ James' novel promoted a proslavery agenda, in contrast to the anti-slavery agendas of Bouvé's and Bontemps's novels. 
${ }^{26}$ Some accounts, including Allen's, record a reward of "5,000 pounds of tobacco" (152) being paid to Birkenhead for his betrayal. Accounts also vary as to the date of the holiday, with some reporting 14 rather than 13 September as the date of commemoration.

${ }^{27}$ See also Herbert Aptheker's American Negro Slave Revolts (International, 1963). Aptheker nonetheless considers the Servants' Plot of 1663 the "first serious conspiracy involving Negro slaves in English America" (164-165). Allen similarly makes a crucial observation concerning black involvement as well as absences in the historical record: "While the record makes no mention of African-Americans in connection with the 1663 plot . . there is no indication of any exclusionary tendency on the part of the plotters; rather, their depositions suggest that they intended to recruit every last bond-laborer to their freedom march" (153). As the status and discontent of free laborers often nearly equaled that of bond-laborers, poor white freemen as well were likely to have been counted among the insurgents without distinction.

See Stephen Saunders Webb, 1676: The End of American Independence (Syracuse UP, 1995) for more on Bacon's Rebellion. It appears as though Johnston took some liberties in juxtaposing some of the specifics of Bacon's Rebellion onto elements of the Servants' Plot, specifically since Bacon's Rebellion offers a somewhat different dynamic in terms of the relationships between and among its participants, its ultimate outcomes, and its revolutionary legacy. Webb describes "Bacon's Revolution” as a conflict between three groups: the English royalists, led by Governor Berkeley, the Anglo-American laborers, and the Native Iroquois (3). While it remains uncertain whether or not African Americans participated in the Servants' Plot, multiple historical sources indicate that black slaves played an integral part in Bacon's Rebellion twelve years later. Both Breen and Webb recount the surrender of rebels at the plantation of Colonel John West in 1676 after Bacon's death, noting that at least 80 of the 100 holdouts were black soldiers. Breen points out that "if the colonial gentry had been as worried about the danger of black insurrection in 1676 as they were in the eighteenth century, one would have expected some writer to have condemned Bacon's arming of the slaves," evidence of which he finds conspicuously absent (11). Webb, however, notes that "the eighty, and most of the revolution's other black soldiers, were returned to slavery, even in instances where they had been promised their freedom as the price of laying down their arms" (6), an outcome which indicates more solid racial divisions within the laboring classes at this time, at least from the perspective of the royalists, than either Breen or Allen would suggest.

${ }^{28}$ See George C. Longest, Three Virginia Writers: A Reference Guide (G. K. Hall, 1978). 
${ }^{29}$ John Brown to his son Jason, qtd. in Quarles, p. 35. 


\section{Chapter 4. "A Riot is At Bottom the Language of the Unheard" Works of Sutton Griggs and Mark Twain}

The colored race has historians, lecturers, ministers, poets, judges, and lawyers, - - men of brilliant intellects who have arrested the favorable attention of this busy, energetic nation. But, after all, it is the simple, homely tale, unassumingly told, which cements the bond of brotherhood among all classes and all complexions.

-Pauline Elizabeth Hopkins, Preface to Contending Forces: A Romance Illustrative of Negro Life North and South (13)

In her biographies written for the readers of The Colored American Magazine, Pauline Hopkins appropriates an Emersonian discourse of "history [as] firmly embedded in individual narratives" (Doreski 5). Working in "the shadow of compromised citizenship cast by Plessy $v$. Ferguson," as C. K. Doreski observes, Hopkins adapts "the New England regional tradition of biography as the spiritually or ideologically informed presentation of exemplary lives" for the explicit purpose of challenging the collective historical narrative by which Anglo-American subjectivity has been both created and nurtured over the course of more than three centuries (45). However, as Hopkins herself makes clear, her fictional counternarratives of American history generally and of African American slavery more particularly serve similar purposes of retrospectively recording an alternative historical narrative that both privileges black experience and exposes the dependency of traditional Anglo-American success stories on the proceeds of African American labor. With her biographies, as with her fiction, Hopkins stakes a vital claim to the string of stories - biographies of individual lives, public records of climactic events, cultural anecdotes, oral histories, and, not least of all, rumors - which combine to define a collective narrative of what it means to be an "American" socially, culturally, legally, and politically. 
Like Hopkins, the other writers I have treated in this study employ retrospective rewritings of the racial past as a means of intercepting and potentially shifting the course of history, or of our understanding of history. I have argued that Chesnutt focuses on racial tensions in the present in order to engender a reconsideration of the past and therefore alter the trajectory of the future by expanding the scope of history and its narrative. Chesnutt elevates the dynamics of day to day relationships to the same level of relevance as catastrophic events and thereby forces a more complex discussion of history as multi-layered and multi-leveled. Similarly, Tourgée and Dixon are interpreting the past so as to influence our understanding of events in the present. Dixon outlines a distinctly white supremacist history in order to encourage the proliferation of that history through a defensive sense of pride and entitlement, stirring up emotions directly linked to historical inheritance myths. Tourgée also looks to white supremacist inheritance myths, but he does so in order to provoke a sense of social responsibility and to promote his activist agenda among the nation's most privileged citizens. Johnston and Bouvé apply contemporary political concerns and racial configurations to specific historical moments wherein racial authority is openly challenged, reinforced, and changed in order to mobilize their own marginal authority to reinterpret the past. Hopkins, too, in her fiction, approaches an arguably static narrative of history with the goal of revising our understanding of the past so that we can move forward, toward a different future.

The authors I've considered in previous chapters have all interpreted the racial tensions of the day and the pursuant violence retrospectively, examining the development of the riotous presence in American history and culture. Alternately, in A Connecticut Yankee in King Arthur's Court (1879) and in Imperium in Imperio (1899), Mark Twain and Sutton Elbert Griggs approach these tensions prospectively, imagining a world that extends from the riotous presence. 
Looking back so as to look forward, both of these writers explore in fictional terms the greater processes by which these stories of "exemplary lives" and social progress come to represent the paradigm of American citizenship by looking instead to the underside of the standard narrativeto rumor and to riot. Rather than simply commenting on the riotous presence, Twain represents it in action when he has his protagonist Hank Morgan confuse standard narratives of progress and technological advancement with real republican process. Connecticut Yankee is therefore a novel in which the structural principles of the American social order, along with its enabling ideology, are put into place only to lead to mass destruction. Griggs deals with the same parasitical relationship between structure and ideology in the form of the co-dependence of black resistance and the false consciousness of white freedom. White freedom has, Griggs suggests, become our only understanding of freedom, which virtually eliminates the possibility of true revolution. In depicting the political divisions created by the pressures of developing a black collective within a white supremacist culture, Griggs does indeed offer a vision of imperium in imperio, a nation within a nation, a riotous presence within a riotous presence.

Most of the writers I have examined so far are certainly aware of racial tensions and of sharp discrepancies between the ideal and actual nation or between official and unofficial histories, yet they are relatively unaware of the more insidious relationships between the political order and its maintenance via terror that I have termed the "riotous presence." Indeed, the other authors included in this study have tried to frame those discrepancies, Dixon included, in specific ways - which has led them to portray different manifestations of the riotous presence in their fiction. Where these authors focus on specific contemporary and historical eruptions of violence and then work their way outward, in order to contextualize and situate these moments, and therefore consciously or subconsciously reveal the existence and the rhythms of the riotous 
presence, Twain and Griggs approach their critiques from a somewhat different angle and suggest a more complicated sense of the problems they address. Twain and Griggs are writers who explore the discrepancies (ideal and actual) not as the falling away or corruption of republican ideals of equality and popular representation but as two opposite poles of the US cultural order. As Andy Doolen argues, "these racial fictions - taking the form of the official discourse of law, policy, proclamation, and public ritual—constitute the logic of U.S. imperialism in the late colonial and early national periods, transforming the terror of white supremacy into a rational and permanent presence" (xxi). The logic of Jim Crow in the postReconstruction period depends upon a continuation of these racial fictions, and the terror of white supremacy, both at home and abroad, remains the predominant method of cultural control. Both Twain and Griggs are writers who are influenced significantly by this presence, which has now become more explicit than in the time Doolen studies, and by the kinds of cultural processes and forces I have explored in previous chapters. If their understanding of the riotous presence is incomplete, Twain and Griggs significantly investigate riot and the attendant cultural discrepancies not as rupture but as the very terms of the culture.

\section{Two Americas}

The Person Sitting in Darkness is almost sure to say: "There is something curious about thiscurious and unaccountable. There must be two Americas: one that sets the captive free, and one that takes a once-captive's new freedom away from him, and picks a quarrel with him with nothing to found it on; then kills him to get his land."

--Mark Twain, "To the Person Sitting in Darkness" (1901)

In order to understand how Twain and Griggs are looking to the underside of the standard national narrative and grappling with the complex tensions they find there, it is necessary to understand the interconnected elements of standard public narratives of providential progress and 
American exceptionalism at this particular racial moment. The terror of white supremacy is not only embedded in the official language of laws and public policies; it is threaded throughout the fabric of our national literature, present in the texture of daily life and personal interactions, carried through into the unspoken and the unheard. Officially sanctioned racial fictions, at odds with the idealized narratives of white freedom and universal equality whose structure they uphold, are flawed, divisive, and unstable, requiring constant reaffirmation and reorganization effected via the terror of white supremacy. As Twain and Griggs suggest, this terror is less autonomous than reciprocal, shaping and shaped by the onward march of American history.

Twain and Griggs are writing in an era in which highly-visible white supremacists, like Dixon, Benjamin R. Tillman of South Carolina, and James K. Vardaman of Mississippi, for example, are working to gather the racial past into nationalist fear so as to justify an imperialistic agenda. Although their names have become virtually synonymous with white supremacy and racial terrorism, these men did not independently conjure their rhetoric from thin air, nor were these Southerners alone in their efforts. As Edward J. Blum argues, the post-Civil War "decline in race relations, and the rise of a militarized, imperialistic nation were permitted, and even encouraged, by northern whites, who abandoned the hopes for equality and brotherhood" that many had championed briefly in the immediate postwar period (3). Dixon's popular fiction and the political strategies of Tillman and Vardaman also build on and complement contemporary racist and anti-immigration agendas advanced by prominent political leaders like Benjamin Harrison and William McKinley, labor leaders like Terence V. Powderley and Samuel Gompers, sociologists like E. A. Ross, and novelists like Jack London and Harold Frederic, among others. "I1 was McKinley," Frederickson observes, "who made the most direct connection between the deportation of the blacks and the erection of the barriers to immigration. Noting that 
President Harrison had said in his speech accepting the Republican nomination that the nation had a duty to exclude alien races that could not be assimilated, McKinley concluded that 'our duty to expel alien races is as clear as the duty to exclude them"” (Black Image 265). As Thomas F. Gossett points out, "we find the racist argument in anti-immigration agitation not merely among the defenders of the status quo, but also among men who were to become famous for their concern for the welfare of the masses," like Woodrow Wilson and Frederick Jackson Turner (292-293).

These sorts of appeals to the language of race, white anxiety, and the suggested violence of expulsion points to white America's ongoing obsession with securing its simultaneously permeable and impenetrable geographical, national, and racial borders. Race histories based on popular knowledge and discussing the purported inferiority of non-whites in scientific terms were popular during the 1880 s and 1890 s, and these texts anticipate later alarmist antimiscegenation and anti-immigration works like Madison Grant's The Passing of the Great Race (1916) and T. Lothrop Stoddard's The Rising Tide of Color Against White World-Supremacy (1920). These race histories, like Frederick L. Hoffman's Race Traits and Tendencies of the American Negro (1896), which argues "that the high incidence of tuberculosis, syphilis, gonorrhea, scrofula, and other diseases would lead to their extinction as a race," were "widely read and quoted in the South" (Gossett 281). Arguments like Hoffman's helped to substantiate later assertions, like those made by historian James Ford Rhodes in History of the United States from the Compromise of 1850 to the Final Restoration of Home Rule at the South in 1877 (1906), "that the Negroes were innately inferior and incapable of citizenship" (Gossett 284). Thus, these same "scientific" rationales translated into racial appeals for the exclusion and expulsion of non-white immigrants like the Chinese from California and the Irish and Italians 
from New York in the 1870s and beyond on the grounds that they were unfit for the duties of republican citizenship. In the same vein, anti-imperialist arguments citing contamination and declining "stock" emerged from the same racist foundations as arguments advocating the forcible deportation of African Americans from the nation. As Frederickson argues, "an understanding of the turn-of-the-century debates on America's proper relationship with 'inferior races' abroad requires a recognition of the extent to which racism had been a barrier to imperialism before $1898 "(305)$.

The underside of the standard narrative reveals the perceived threat of immigration, the desire to control other people, and the racial components of class and economic issues. These internal tensions are most evident in the efforts of white supremacists in the late nineteenth and early twentieth centuries to craft a kind of heroic narrative of bringing order to a world that is threatened by the disorder of the non-white presence, while at the same time ensuring the maintenance of white racial purity. Increased contact and expansionism in this period served to further complicate this already convoluted racist discourse, for those who opposed and who supported imperialism alike. "Not only were most of the antiimperialists believers in racial inequality," Frederickson observes, "but the extreme racists in Congress and elsewhere, including Senator Benjamin R. Tillman and most of his Southern colleagues, also tended to oppose Philippine annexation, because, as Tillman put it, 'we understand what it is to have two races side by side that cannot mix or mingle, without deterioration and injury to both and the ultimate destruction of the civilization of the higher" (Black Image 306). Arguments like Tillman's represent divergent interests among the apparently unified white race, particularly in terms of class. The economic interests of the white elite, which depend on contact and 
annexation, threaten the racial security of the white working class, which is no longer predicated on overt distinctions between slave and free.

This internal debate within white supremacy places Twain in necessarily conflicted territory. A relative latecomer to anti-imperialism, Twain satirized America's disingenuous and dystopic vision of freedom in the context of the 1898 Cuban War for Independence and the subsequent Philippine-American War (1899-1902) in “To the Person Sitting in Darkness" (1901). ${ }^{32}$ Couching America's self-proclaimed civilizing mission in economic terms, Twain lampooned "The brand" as "strictly for Export — apparently," although such was "merely an outside cover, gay and pretty and attractive, displaying the special patterns of our Civilization which we reserve for Home Consumption, which inside the bale is the Actual Thing that the Customer Sitting in Darkness buys with his blood and tears and land and liberty" (206-207). In other words, the sort of civilization American imperialists advertise is only available to a select few; all others will receive a cheap and faulty imitation nonetheless clad in the same attractive packaging and, significantly, carrying the same hefty price tag. With this juxtaposition of ideology and economics, Twain reveals the cultural rhetoric of "the white man's burden" to be a self-serving marketing strategy deployed by the white elites of the "Blessings-of-Civilization Trust," which, as Peter Schmidt has observed, "functions more as a corporation operating for profit than government policy created by the consent of the governed" (142). While Twain does not advocate racial separatism, his economic ideology suggests that the bulk of the burden falls on the white working class, at once similarly outside of the white elite Trust and in a position of competition with other non-white “customers.” In this way Twain's aggressively anti-imperialist and potentially anti-racist argument is aligned with the extreme racism of Tillman's. 
Twain does not fit neatly within a white political spectrum that includes Dixon and Tourgée, but that is precisely the point. There was no linear continuum, no sliding scale, no clear means of accounting for internal differences between whites and the roles those differences played in the maintenance and proliferation of white supremacy. As Frederickson suggests, "it may even strike modern readers as an exercise in hairsplitting to distinguish the moderates from the militant racists with whom they professed to disagree" (285). What is most interesting is that whites used the same rhetoric to disfranchise and debase African Americans and non-whites as to condemn white violence against them. In the wake of the 1906 Atlanta race riot, according to Frederickson, white civic leader Charles T. Hopkins deployed the rhetoric of paternalism to condemn the white mob: "“The Negro race,' Hopkins admonished the purveyors of fear and defenders of violence, 'is a child race. We are a strong race, their guardians. We have boasted of our superiority and we have now sunk to this level—we have shed the blood of our helpless wards. Christianity and humanity demand that we treat the Negro fairly. He is here, and here to stay"” (287). ${ }^{33}$ Similarly, Twain's anti-imperialist argument in "To the Person Sitting in Darkness" appeals to an idealistic notion of fairness and of white America's ability to bestow that fairness upon others when they cannot seem to reach agreement even among themselves. Twain, however, seems to recognize, even if he is unable to resolve, the inherent disorder of the US social order. Differentiating between the "Actual Thing”- a qualified race and class-based hierarchy—and the version of "Civilization which we reserve for Home Consumption"exceptionalism and entitlement—Twain muses: "Is there a difference between the two brands? In some of the details, yes" (207). 


\section{Ordering Disorder in Connecticut Yankee}

Mark Twain wrote Connecticut Yankee in the years between his legendary success with The Adventures of Huckleberry Finn (1884) and his subsequent work on an uncompleted "Sandwich Islands Novel," the latter which was directly inspired by and attempted to capture Twain's nostalgic vision of his life-changing six-month trip to Hawaii in 1866. Upon his return from Hawaii, Twain embarked on a lecture tour which "thus positioned him in an implicitly racialized discourse of national identity where he could perform as a civilized white American by virtue of his travels among primitive peoples" (Kaplan 60). "Mark Twain," Amy Kaplan asserts, "became audible as an 'authentic' American voice while speaking as an authority about those whom he called 'Our Fellow Savages"' (59). In this way, despite "express[ing] ambivalence and irony about his own participation in the imperial project," Twain nonetheless perpetuated national assumptions about history while defying his own working class status by claiming for himself a position among the white majority (61). By the early 1900s, however, Twain had become a leader in Boston's elite Anti-Imperialist League (Schmidt 135). Schmidt suggests that Twain's ideological transition was neither a quick nor an easy one. "To the Person Sitting in Darkness," Schmidt observes, "seethes with Twain's fresh sense of betrayal," as he was a "rather late convert to anti-imperialism. As recently as 1898 , despite doubts about colonialism expressed in Following the Equator, Twain admitted to a friend that he believed the United States' war with Spain was exceptional" (142). John Carlos Rowe observes that Connecticut Yankee is often critically neglected in terms of its value as anti-imperialist discourse, because, "published in 1889, [it] belongs to the decade preceding Twain's overt 'change of mind' about the dangers of colonialism and imperialism" (123). Connecticut Yankee, then, can be read in the context of Twain's working out of this imperial ambivalence, wherein Twain does not resolve 
contradictions or ideological paradoxes but rather is adept at representing these contradictions in action.

Hank Morgan, Twain's idealistic protagonist in Connecticut Yankee, fundamentally misunderstands republican process, in many ways replicating the sort of imperialist project that Twain critiques in "To the Person Sitting in Darkness." This is first revealed through the "miracles" he enacts, engendering both fear and awe in the gentry and the commoners alike. Catapulted from nineteenth century Connecticut into sixth century England, Morgan initially manipulates his captors with his foreknowledge of the solar eclipse, convincing King Arthur and his would-be executioners that he commands even the sun. Recognizing in Morgan a fellow charlatan, the fabled Merlin is suspicious of him from the start. What begins with an act of selfpreservation quickly becomes a deceptive contest for power and status between Morgan and Merlin. When, soon after the eclipse, the "multitudes presently began to agitate for another miracle," Morgan contrives to blow up Merlin's tower with some blasting-powder, a lightening rod, and some wires (55-56). His technological savvy again proves successful, and Morgan concludes that the "miracle" was "effective." Moreover, the "great bothersome temporary population had vanished. There were a good many thousand tracks in the mud the next morning, but they were all outward bound. If I had advertised another miracle I couldn't have raised an audience with a sheriff' (59). Early on Morgan establishes a discourse of consumerism with the use of terms like "advertised" to indicate his conception of his miracles as product and of the people as consumers of that product. Morgan further observes that in the wake of his victory over Merlin that "Merlin's stock was flat," suggesting that the power to awe is indeed the power to rule and that Morgan has effectively bankrupted Merlin's authority (59). 
Morgan's feud with Merlin illustrates the cultural importance of the appearance of authority as well an underlying and often conflicting ideology of authenticity. Both magicians are vying for the sanction of the king as well as for popular favor, yet both are simultaneously working to expose the other for the fraud that he is. Morgan sees Merlin as unscrupulously influencing the people and the king with his "parlor-magic" in order to secure for himself a place among the privileged, but Morgan fails to see how he is replicating the same process with his “superior" technological prowess (59). Morgan initially sees his own manipulations as noble, despite the fact that he, too, is merely creating fantastic illusions to increase his value both as an entrepreneur and as a dignitary. By the time the Yankee performs his miracle at the Abbott's well, he has become both arrogant and disaffected, criticizing Merlin for being "an old numbskull; a magician who believed in his own magic; and no magician can thrive who is handicapped with a superstition like that" (209). At this point, the Yankee has reached a somewhat more sophisticated understanding of his own misdirection, but he still sees the ends as justifying the means. Morgan goes on, along with his team of privately trained experts, to stop the leak via simple masonry techniques: "My boys were experts in all sorts of things, from the stoning up of a well to the constructing of a mathematical instrument. An hour before sunrise, we had that leak mended in a ship-shape fashion, and the water began to rise" (218). Of course, the absurd ritual and the pyrotechnics display that follow are quite another matter. Engineered not to reveal but to hide the actual method of fixing the well, the Yankee's grand performance is more spectacular but also more calculatedly dishonest than Merlin's.

In place of true republican practice, Twain suggests, Morgan has become a master of crowd control. This involves not only the ritual of violence but the sale of his underlying ideology to the pilgrims and the unwashed masses he terrorizes with his pyrotechnics and 
explosives. If Morgan had simply fixed the well, using what he considers to be common knowledge in the nineteenth century, he would likely have been jailed and perhaps executed for heresy in the sixth century, as the people believe that the holy well has been struck dry by the divine hand of God. In order to communicate with the pilgrims who revere the well as sacred, Morgan must reach them on their own level. The old Abbot advises Morgan that he must bring the water back "with enchantments that be holy, for the Church will not endure that work in her cause be done by devil's magic" (205). There must be a discursive agreement among Morgan and the Abbot as to the nature of Morgan's enchantments, but even this is part of the show. The crowd is also complicit. They want to see a miracle, not a mason.

Morgan is using deception to engineer a people's revolution—without the express consent of the actual people. The Yankee's secret team of experts, his "teacher-factor[ies]," his "West Point," and his "naval academy" all beg the question of why this education, this onset of nineteenth-century civilization, must be carefully dispensed to a chosen few rather than spread among the masses, theoretically enabling the serfs and the peons to participate in if not to orchestrate their own uprising (81-83). In fomenting his underground revolution in the name of the masses, the Yankee represents a mode of understanding in many ways similar to that of Tourgée's Fool. Morgan sees himself as the answer, the savior, and the embodiment of republicanism, and, above all, he thinks he can bring about a people's revolution without violence. Conversely, he sees the masses, implicitly or explicitly, as backward and in need of his protection and guidance. He fancies himself singularly capable of creating a republican society within the framework of a feudal one: "My works showed what a despot could do, with the resources of a kingdom at his command. Unsuspected in this dark land, I had the civilization of the nineteenth century booming under its very nose!” (82). However, Morgan does not seem to 
understand the depth of his self-deception, his own disgust for and distrust of the masses, or the ideological consequences of the elaborate charade by which he is undermining rather than encouraging true republican process. To encourage the masses to participate in their own revolution would be to engender violence and riot, and therefore the Yankee pronounces himself "the despot" in the name of peace.

The Yankee's distrust of the masses is seemingly confirmed when he witnesses the work of a riotous mob. In the wake of a devastating manor house fire, the baron is found murdered, bound and stabbed, and the locals form a mob intent on avenging the crime. Despite, or rather because of, the fact that "suspicion fell on a humble family of the neighborhood who had been treated with peculiar harshness by the baron," the final tally is "eighteen persons hanged or butchered; and two yeoman and thirteen prisoners lost in the fire" (295-296). Horrified less by the absence of what he considers to be rational procedure than by the resultant gratuitous violence, Morgan is most surprised by the people's ability to turn against their neighbors: "The painful thing observable about all this business was, the alacrity with which this oppressed community had turned their cruel hands against their own class in the interest of the common oppressor" (297). Furthermore, Morgan cannot understand why, when there was ample time to save the family from the burning manor house, no one thought to release the locks on the prisoners' cells. "Would one unlock the vaults at such a time? Marry, some would have escaped," is the reply when Morgan questions his yeoman hosts about the fatalities. Morgan fails to see that the peasants are complicit in the feudal narrative that constructs the prisoners as situated differently than themselves, but he, in turn buying into the same narrative, sees the peasants and the prisoners both as ideologically if not essentially beneath his own status. 
Accordingly, Morgan wants to see the peasants and the prisoners - all the people save the nobles - as a community bound by their common oppression. His precious little faith in their capacity for resistance is rocked by what he sees as internal discord. Morgan's contrived people's revolution is both predicated on and undermined by his belief that the sixth-century peasants must be coached and cajoled by the Yankee and his secret contingency to want, demand, or even to be able to conceive of a world in which they are propertied citizens, a world in which birthright is not all-important. According to Morgan, “Arthur's people were of course poor material for a republic, because they had been debased so long by monarchy" (242). This explanation reaffirms Morgan's inability to see beyond the surface of the situation, to see the complexity of and cultural constraints imposed upon the daily lives of the "debased" people in question. The Yankee's yeoman host explains his motivation and his participation in the riot: "I helped to hang my neighbors for that it were peril to my own life to show lack of zeal in the master's cause; the others helped for none other reason. All rejoice to-day that he is dead, but all do go about seemingly sorrowing, and shedding the hypocrite's tear, for in that lies safety" (299). The yeomen are at once victims of the oppressive feudal monarchy, terrorized into submission, and complicit in inflicting terror upon others. The arguably botched riot is for Morgan both evidence of the people's innate capacity for violence and that the potential for building a republic exists within them. The requisite qualities are one and the same.

Looking forward to the nineteenth century, Morgan identifies poor southern whites, who were nearly as degraded by the presence of slavery as the slaves, as exemplary of this phenomenon in their willingness to side with, and even to fight for, the continuation of slavery, by which they directly profited neither politically nor economically. Twain satirizes Morgan's philosophy of assisted redemption when he places it within the context of the antebellum South: 
"And there was only one redeeming feature connected with that pitiful piece of history; and that was, that secretly the 'poor white' did detest the slave lord, and did feel his own shame. That feeling was not brought to the surface, but the fact that it was there and could have been brought out, under favoring circumstance, was something — in fact it was enough; for it showed that a man is at bottom a man, after all, even if it doesn't show on the outside" (297). Who, exactly, does Morgan imagine is supposed to bring this potential out of the contemporary poor white? With no time-traveling explosives-toting Yankee presently available for the job, this latent potential remains moot, which begs the question: how is a man truly "a man" if he doesn't act upon his convictions? Twain reveals mechanisms in place that at once revere and contain the insurrectionary potential of the white working class until it can be mobilized by an empowered elite in service of some greater purpose, yet he is also critical of the mob who would rise in service of their oppressors but not in defiance of them.

By the time of the manor house riot, Morgan has begun to develop a growing respect for the king and for the natural aristocracy he represents. That Morgan sympathizes with the king, and sees the king's relative goodwill as exceptional with respect to overtly cruel nobles like the dastardly Madame le Fay and presumably the recently deceased baron of the manor house, is evident in the details of his long-term revolutionary plan. Morgan predicts "a modified monarchy, till Arthur's days were done, then the destruction of the throne, nobility abolished, every member of it bound out to some useful trade, and the whole government placed in the hands of the men and women of the nation there to remain" (300). His subconscious recognition that a people's revolution necessarily entails the defeat and displacement not only of the existing abstract monarchy but also of his new friend Arthur contributes to Morgan's more gradual proposal. Despite the fact that he sees Arthur as exceptional, as somehow disconnected from the 
larger corrupt aristocracy he represents, Morgan attributes the same redeeming qualities he sees in the king to other nobles, ultimately to his detriment. When the Yankee and the king alienate a group of peasants with their strange behavior and are subsequently treed by yet another clamoring local mob, Morgan expresses relief upon hearing the voice of an approaching horseman: "How good it sounded! The owner of the voice bore all the marks of a gentleman: picturesque and costly raiment, the aspect of command, a hard countenance, with complexion and features marred by dissipation" (343). This man's voice and appearance identify him as a gentleman, and Morgan, immediately expecting an ally, feels comforted by his presence. However, after violently driving off the mob of peasants, the gentleman gives the king and the Yankee a night of respite in familiar surroundings befitting their proclaimed stature before selling them, to their astonishment, at a slave market.

This sequence of events evokes the specter of white slavery in the nineteenth century, wherein countless verdicts hinged on the observable whiteness of the person, whose slave or free status was in question. In such trials, as legal historian Ariela J. Gross has argued, "racial identity became a question of performance, reputation, and common sense," in other words, "a complicated system of contradictory clues, something that respectable white people were nevertheless supposed to recognize at first sight" (31). The overwhelming problem for the Yankee and the king is that there appears to be no such system in place in feudal England. The king, disguised to facilitate his ability to travel among the commoners, is not easily recognizable as one who is, by rights, not a slave. Initially it strikes Morgan as "unaccountably strange and odd, that the king of England and his chief minister, marching manacled and fettered and yoked, in a slave convoy, could move by all manner of idle men and women" and "never provoke a single remark" (347). At first Morgan concludes that this "only shows that there is nothing 
diviner about a king than there is about a tramp, after all," but this hypothesis cannot stand (347). Morgan's real moment of epiphany comes, after the king has fetched a disgracefully low price at sale, when Morgan exclaims: "it was natural. For this reason: a king is a mere artificiality, and so a king's feelings, like the impulses of an automatic doll, are mere artificialities; but as a man, he is a reality, and his feelings, as a man, are real, not phantasms" (351). Although Morgan makes this statement in response to the king's whining over his insultingly low sale price, he simultaneously suggests that even if the king is not immediately recognizable as the king (disguises notwithstanding), he should be recognizable as a noble personage suitable for royalty. There should be some innate and innately free something about the king that the people can easily identify.

Morgan ultimately tries to shift his sense of a natural aristocracy to represent republican theory. This process involves violently replacing the standing aristocracy with a contingency of men who should rule not by birthright but by virtue of some proven merit. At the same time, the peasants remain peasants and the slaves remain slaves, their own latent revolutionary tendencies romanticized in the terms of Morgan's flawed ideology and desirable only as long as these inclinations remain latent. Regardless, one ruling class is displaced by another, and the stakes of the requisite merit are never entirely clear. Twain makes the futility of this abstraction apparent in the conversation between Clarence and the Yankee, wherein they debate the concept of republican theory. Clarence's “idea was a Republic, without privileged orders, but with a hereditary royal family at the head of it instead of an elective chief magistrate. He believed that no nation that had ever known the joy of worshipping a royal family could ever be robbed of it and not fade away and die of melancholy." When Morgan cautions Clarence that "kings [a]re dangerous," Clarence responds: "Then have cats." Clarence insists that cats "would be as useful 
as any other royal family, they would know as much, they would have the same virtues and the same vices, the same fidelities and the same treacheries, the same disposition to get up shindies with other royal cats, they would be laughably vain and absurd and never know it, and they would be wholly inexpensive" (399). Contained in Clarence's suggestion is Twain's commentary not on the dysfunction of the system but on the danger of the human element. The problem with kings is that they hold the power of kings, and this danger is present whether or not that power is wrought by heredity or by popular vote. As the disingenuous enthusiasm of the peasants' mob illustrates, popular vote does not necessarily represent the independent will of the people but, rather, their collective bid for survival in the face of dominant expectations.

In trying to replicate a people's revolution via the familiar blueprint of American narratives of romanticized individualism and collective independence, Morgan instead represents the riotous presence in action. Morgan successfully enacts the structural principles of the American social order, along with its enabling ideology, and instead of the "peaceful revolution" he desires, his machinations ultimately lead to mass destruction (183). Morgan's conceptual revolution is tragically flawed, because he brings with him from the nineteenth century, along with thirteen centuries' worth of technological advancement, thirteen centuries' worth of strategic domination that has been actively cultivated and perversely perfected over time. Rowe notes that the "knowledge of astronomy" on which Morgan depends "to predict the life-saving solar eclipse ... is just the sort of scientific knowledge early European explorers used to gain authority over local, less technologically advanced peoples" (136). Such comparisons extended over the course of the novel support Rowe's claim that "Twain organizes Connecticut Yankee around a general critique of slavery's historical persistence from feudalism to capitalism" (134). However, slavery's trajectory is less linear than circular in Twain's rendering, and the fact that a 
"superior" race of people have labored for centuries to rationalize rather than to eradicate this blight on human existence is central to Twain's observations.

The Sand Belt finale emphasizes the depth and breadth of destruction made possible by nineteenth-century technological advancement and mechanized warfare, and it also accentuates the reliance of American narratives of progress and independence on the presence of an essentially unfree racial other. Morgan's self-identification as American in the racialized terms of Anglo-Saxon Providentialism echoes the objections of many antebellum opponents of Manifest Destiny and immediate expansion to "the use of overt force" rather than to "the view that Americans were a distinct race" (Horsman 253-254). In fact, many antebellum Americans defined their superiority, their "chosen" status, in terms of "the necessity for restrained conduct befitting their high station. Superiority did not confer the right to wage aggressive war" (Horsman 257). This is Morgan's attitude at the start of the novel, that the sixth century British, nobility and peasantry alike, are barbaric, while he, Morgan, is set apart by his refined character. "Imperialist nostalgia," Kaplan suggests, "disavows the history of violence that yokes the past to the present, as in Hank Morgan's longing for the 'Lost Land' of Camelot, which he destroys at the end of Connecticut Yankee" (56). In the Battle of the Sand Belt, Morgan's progressive technology is revealed to be just as barbaric as the feudal methods he seeks to displace and superior only in its ability to wreak havoc on a grander scale. Although Rowe's suggestion that "Twain's generalization of slavery across the ages risks trivializing its modern consequences" is not without merit, Twain's retrospective imposition on the sixth century of race as the basis for economic exploitation is less a risky generalization than an adept illustration of the hubris of white supremacists and the degree to which modern notions of racial superiority have infiltrated human consciousness. Race as an ordering principle has become so prevalent within American 
culture that the "Yankee" - a term which "was itself shifting geographically at the time, referring not only to Northerners in relation to Southerners but also to the nation as a whole to international locations of imperial intervention" (Kaplan 88) - is prepared to rewrite his own history, to destroy his past and his forebears if necessary, in order to render that superiority absolute.

Morgan's experience gives the lie to white working class men's sense of entitlement, by virtue of race and gender, to the full privileges of republican culture. As Henry Nash Smith has observed, "Hank Morgan belongs to the working class; he has risen from the ranks of workers to the position of superintendent in the Colt arms factory in Hartford" (38-39). Morgan's class status positions him simultaneously as the idealized embodiment of the American work ethic and as firmly entrenched within the subjugated white working class. Regardless of his industrious and self-motivated climb to management status, Morgan cannot transcend his birth or his history; he is and will always be a worker rather than a noble. Smith's further observation that "Unlike Huck Finn, who is not at ease with concepts, the Yankee is passionately devoted to general ideas such as progress, civilization, justice, equality before the law, universal suffrage, representative government, free trade, and separation of church and state" (68), points to Morgan's conflicting belief in these principles as ideology and his own class-based exclusion from full participation in their practice. Morgan's paradoxical status within the standard narrative contributes to his inability to differentiate between true republican practice and its imposter. Consequently, he cannot see the danger of misjudging "the degree to which republican aims and their emancipatory struggles can be distinguished from the tiresome business of conquest by kings, priests, and tycoons" (Rowe 125). Morgan fails to realize that revolution is by nature circular, or 
that the freedom of some necessitates the unfreedom of others, those who might be the next to agitate for their liberty from new forms of oppression.

\section{The Circus of Riot}

I have argued that Mark Twain sees beyond the logic of a neat discrepancy to the chaotic heart of the riotous presence, but he could only see so far, particularly while immersed within the very culture he works to critique. Accordingly, Hank Morgan is trapped within the same conspicuously white and markedly violent version of history as are Tom and Huck in Twain's later novel, Huck Finn. This history cannot be overcome or even derailed by the mere recognition of humanity across race or class lines, as Huck's relationships with Jim and with Tom illustrate. Standing in for "the (un)reconstructed South," as Jocelyn Chadwick-Joshua observes, Tom "relies on and perverts every concept on which the South presumably structured its mythic persona: pride, rightness, filial loyalty, honesty, and salvation." Chadwick-Joshua is more disturbed by "Huck's faith in Tom's sincerity" than by Tom's contrived game to free the already-free Jim (120). Huck, despite his earnest friendship with Jim and the "lessons" he has learned via their common adventure, nonetheless accepts Tom's game and allows it to proceed to a point at which the novel becomes nearly unbearable to read. Because Huck admires Tom's superior education and penchant for reading, he defers to Tom's insistence on performing Jim's escape from slavery in accordance with the "rules" of a supposedly standard narrative. Huck, however, is unable to understand that Jim's experience of incarceration is very real and that Jim is forced to comply with Tom's increasingly absurd demands not just because Jim is a slave and Tom is a white man but because Jim's role in Tom's master narrative is to supplement the white boy's adventure. 
Both Tom and Huck assume a white narrative of American history suggested in the appropriately named wrecked and plundered boat in Chapter XIII, the Walter Scott. The name of the vessel evokes the narratives of English writer Sir Walter Scott, whose Waverly novels, particularly Ivanhoe (1819), were exponentially popular in the antebellum United States and especially in the South. As Reginald Horsman argues, "Scott's impact generally was to bind Americans firmly to their English roots and to reinforce them in the idea that America, a country which in reality increasingly consisted of a blending of races, was the new bastion of an old and successful English people" (161). Huck and Jim alight only briefly on the Walter Scott's decks, but they cannot escape the cultural framework defined by this particular historical narrative, just as Twain cannot stand entirely outside of his own cultural history in order to level his sharp critique of the imperial politics and capitalist agenda that Horsman and Kaplan describe.

In Connecticut Yankee, Twain conjures the specter of a different past, one contrary to the celebrated democratic ideals of rugged individualism and moral triumph on which novels like Huck Finn, wherein the white male nation purportedly comes of age with the novels' main characters, are predicated. The white male's cognizance of what he is not - a slave-is central to this process. Toni Morrison argues that the Africanist presence in white literature enables white thinking about the grand metaphorical questions. Of Huck Finn, Morrison writes: "Thus the fatal ending becomes the elaborate deferment of a necessary and necessarily unfree Africanist character's escape, because freedom has no meaning to Huck or to the text without the specter of enslavement, the anodyne to individualism; the yardstick of absolute power over the life of another; the signed, marked, informing and mutating presence of a black slave" (56). Jim's presence and the very real consequences of his capture make the adventure authentic for Huck; at the same time, Jim stands in as a "yardstick" by which to measure Huck's own freedom, to 
qualify Huck's fugitive status, to encourage Huck's individualist moral development within the immoral world of slaveholders, abusive parents, murderers, thieves, and "rapscallions." The Africanist presence, then, provides a necessary foil to white American tales of moral and social progress, of democratic wholeness, of Manifest Destiny and capitalist opportunity.

The highly-contested ending of Huck Finn is less about Jim's freedom-Tom Sawyer knows, if we do not, that Jim has already been legally freed - than it is about his place in Tom's master narrative. As Morrison suggests, "it is not what Jim seems that warrants inquiry, but what Mark Twain, Huck, and especially Tom need from him that should solicit our attention. In that sense the book may indeed be 'great' because in its structure, in the hell it puts its readers through at the end, the frontal debate it forces, it simulates and describes the parasitical nature of white freedom" (57). Importantly, Tom and Huck need more than Jim's mere presence to solidify their own adventure. Indeed, they need Jim's resistance, his counter to the cherished narratives of white civil society. Jim's qualified and cooperative resistance under Tom's tutelage simultaneously serves to reaffirm these narratives and allows Huck to repeat the process again and again. At novel's end, Huck decides that he should "light out for the territory ahead of the rest, because Aunt Sally she's going to adopt me and sivilize me, and I can't stand it” (293). Huck's final words are "I been there before" (293), and he has. Jim's slave presence counterbalances Huck's fugitive status during their travels on the Mississippi, and then Jim's abstract freedom, rather than its cost, grants Huck the liberty to embrace his own Manifest Destiny as a rebel child but an independent American explorer nonetheless. In other words, Jim's illegal and unsanctioned personal rebellion reaffirms Huck's normative defiance of social codes.

Tom and Huck's need for Jim's “resistance," which will later be deemed moot, gestures toward the relentless underlying rumors of violent protest which are the private doppelgangers of 
fabled public narratives of cultural development and social education. Many of these rumors, asserting "that blacks will rise up in rebellion," as academic folklorists Gary Alan Fine and Patricia A. Turner observe, "recognize the oppression that blacks have suffered and, as a result, they have a compelling plausibility" (42). The tenacity of these rumors over time and across ostensibly divided historical eras underscores the ongoing presence of riot as an integral part of our nation's enduring legacy of race and class oppression.

Americans do want to see someone stand up to the riotous presence, as Colonel Sherburn does in Huck Finn's "Lynching Bee" scene. Sherburn appears quite the hero to Huck when he “takes his stand, perfectly ca'm and deliberate" and defies the raucous members of the lynch mob that would hang him (145). Sherburn's speech indeed makes us feel like celebrating manly independence and self-assurance when he disparages the mob for its cowardice: "Because you're brave enough to tar and feather poor friendless cast-out women that come along here, did that make you think you had grit enough to lay your hands on a man? Why, a man's safe in the hands of ten thousand of your kind -as long as it's daytime and you're not behind him" (145). Sherburn defines himself in contrast to the mob, among which he declares there is "only half a man" and a bunch of cowards who will "hang yourselves onto that half-a-man's coat-tail, and come raging up here swearing what big things you're going to do" (146). According to Sherburn, the mob is cowardly and pitiful because "they don't fight with courage that's born in them, but with courage that's borrowed from their mass" (146). Standing alone against the mob and against its cowardice does indeed appear to be the mark of Sherburn's singular manliness, especially when the mob suddenly disperses, its would-be leader "looking tolerable cheap" (146).

In making this final observation, Huck seems to have forgotten the crime that has provoked the mob in the first place. Sherburn, self-proclaimed man amongst men, has killed an 
innocent man in cold blood. Old Boggs is obviously drunk and has come to town swearing to kill Sherburn, who is apparently a random representative of Boggs's anger at being "sassed," as the locals "wonder who he's a-gwyne to chaw up this time. If he'd a-chawed up all the men he's ben a-gwyne to chaw up in the last twenty year he'd have considerable ruputation now" (141). The amused tolerance of the townspeople identifies Boggs's threats as empty and the man as a local joke who "never hurt nobody, drunk nor sober" (141). Although clearly aware of Boggs's penchant for drunken drama, Sherburn shoots him dead in the middle of the street, with Boggs's young daughter looking on. Sherburn may have satisfied his own requirements for justified violence - after all, it is daylight and his victim was facing him — but his deed is no less cowardly than the proposed violence of the mob. Before Sherburn shames them with his rhetoric of manly independence, it is the mob who works in service of justice in their collective effort to punish Sherburn for his predatory behavior. Confused by the abrupt turn of events, Huck decides not to stick around after the mob disperses, and instead he goes immediately to a circus (147).

Twain's description of the circus scene in Huck Finn does provide a rather apt metaphor for the riotous presence of white American ideology. Huck's first impression is of the orderliness and the loveliness of it all, in contrast to the attempted lynching he has just witnessed, as the performers "come riding in, two and two, and gentleman and lady, side by side" (147). The graceful procession, however, quickly seems to spin out of control, as "faster and faster they went, all of them dancing, first one foot in the air and then the other, the horses leaning more and more, and the ringmaster going round and round the center pole, cracking his whip and shouting 'Hi! - hi!' and the clown cracking jokes behind him” (147). This is fine and well, and Huck is fantastically amused by the elaborately choreographed show, until "by and by a drunken man tried to get into the ring - said he wanted to ride" (148). This drunken man disrupts the show, is 
heckled and cajoled by the performers and the ringmaster, and eventually causes a near-riot within the ring as spectators "begun to pile down off the benches and swarm toward the ring, saying 'Knock him down! Throw him out' and one or two women begun to scream” (148). This drunken man, who we soon find out is actually part of the show, enjoys a raucous, wild ride around the ring before peeling off the layers of his disguise. Huck is both thrilled and surprised to see that the imposter is one of the ringmaster's own men, and he believes the ringmaster to be truly astonished as well. Huck is terribly impressed with the performer's antics, believing that "he had got up that joke all out of his own head, and never let on to nobody." While Huck admits to feeling "sheepish enough to be took in so," he adds that he "wouldn't 'a' been in that ringmaster's place, not for a thousand dollars" (149). Just as he fails to understand that the man's antics are part of the show and that the ringmaster has been in on the sham all along, Huck fails to recognize that the image of white independence, embodied both by Sherburn and by the rabble-rousing circus performer, is a similar sham of greater proportions.

\section{Imperium in Imperio}

This new revolution which had begun went on. The Klan increased in numbers and in power,an imperium in imperio, - until its decrees were far more potent and its power more dreaded, than that of the visible commonwealths which it either dominated or terrorized.

-Albion W. Tourgée, A Fool's Errand: By One of the Fools

If the circus scene from Huck Finn stands in as a metaphor for the riotous presence in action, for the normal functioning of an American social structure predicated on ideologies of white manly independence, then the secret African American government of Sutton Griggs's Imperium in Imperio serves as a metaphorical circus within a circus. In Twain's novels, the Africanist presence of which Morrison writes is uncomfortably suppressed, latent and 
troublesome, similar to but separate from the revered revolutionary potential of peasants and poor whites. Huck Finn's lynching scene, significantly, is enacted entirely by whites. Boggs is white, Sherburn is white, and the mob is white. There are black characters present_-"nigger boys in every tree, and bucks and wenches looking over every fence; and as soon as the mob would get nearly to them they would break and skaddle back out of reach" (145) — but they are spectators, kept at arm's length from the action of the scene. Huck's description of their presence is extremely brief but notable, because the blacks in the background enable the resolution of the conflict between Sherburn and the white mob. The ghostlike presence of the slaves allows for Buck Harkness, the would-be leader of the mob, to retain some degree of manhood. Even Sherburn still regards Harkness as "part of a man" though Sherburn's speech is designed to utterly embarrass and demoralize Harkness and the others (146). The presence of the slaves, however, neutralizes the conflict and positions the mob as both capable and worthy of redemption. Not as "manly" or as righteous as Sherburn, neither are they as debased as the fleeting creatures in the background who know the true power of the lynch mob. In Imperium in Imperio, Sutton Griggs both replicates and inverts the terms of the riotous presence, bringing the African American characters to the forefront of the conflict and displacing the white characters behind the fences and tree lines of his characters' developing personal politics.

Accordingly, Griggs's narrative focuses on two men who have been shaped by the riotous presence in American culture and on the challenges they face in mounting a concentrated African American resistance effort within a white supremacist culture. If white supremacy indeed looks like the multi-layered performance of Huck Finn's circus, and if white independence and qualified resistance are both built into the script, then what must real resistance, real independence, real black nationalism look like? For Griggs's Imperium, the structure of which 
mirrors in many ways the structure of the white American government, the terms of black independence can neither be cast in the same terms as white independence nor can they be cleanly separated from the demands of white supremacy. Black resistance and the falseconsciousness of white freedom are co-dependent, and, for Griggs's dual protagonists upon whose unfreedom the riotous presence thrives, the parasitical nature of white freedom becomes a nearly insurmountable obstacle to peaceful or intellectual strategies of collective resistance. The riotous presence virtually forces Griggs's fictional regime to undertake the violent overthrow of the standing national government in pursuit of freedom. Like Connecticut Yankee, Griggs's Imperium in Imperio follows the structural logic of white American independence and necessarily ends in tragedy, suggesting that black self-determination can also be parasitical.

The African American presence, subtle and separate in Twain's lynching scene, becomes more pronounced in Griggs's novel, calling to mind the historical interdependence of white and black, foreign and domestic. In the 1830 s and 1840 s, as at the turn of the twentieth century, American imperialist politics were inseparable from the politics of racial repression within the nation's geographical borders. In 1831 the Supreme Court relegated Native Americans to the economic and geopolitical hinterland of "domestic dependent nations" via its decision in Cherokee Nation v. The State of Georgia, thereby "plac[ing] the foreign inside the geographic boundaries of the nation," according to Kaplan (27). The Texas Revolution in 1837, the US annexation of Texas as a slave state in 1845, and the Mexican-American War from 1846-1848 further contributed to increasing anxieties among white Americans about maintaining the separation of foreign and domestic and to the solidification of mutually constitutive and explicitly gendered imperial metaphors of domesticity and Manifest Destiny. Embedded within these twin rhetorical structures for antebellum Americans was an innate fear of the seemingly 
limitless frontier and of the racial others who must be either eradicated or absorbed within the nation's mobile borders. Gendered discourses of domesticity deploying "the home as a bounded and rigidly ordered interior space" served to counterbalance or stabilize fears of miscegenation and of economic displacement generated by expansion and encounter (Kaplan 25). The metaphorical home was a safe-haven, a protected internal domain conceptually removed from external contact and therefore from the possibility of racial and national contamination.

Antebellum discourses of domesticity and of Manifest Destiny also shared with each other and with postbellum imperialist discourses underlying ideologies of American exceptionalism underscored by the existence of racial others. In tracing the thrust of American nationalist thought from the optimistic Anglo-Saxonist pride of the early republic, in which environmentalism outstripped essentialism in terms of racial and national difference, to the increasing "belief that the Americans were the most distinguished descendants of the AngloSaxons" (81), Horsman defines a particular nationalist conception of "the 'American' as a distinctive race, a race in which was combined the best elements of the Caucasians ... [and] was usually given the historical attributes of the Anglo-Saxons" (164). Democratic politician John L. O'Sullivan coined the phrase "Manifest Destiny" in the 1840s in response to those who opposed the annexation of Texas and therefore the Providential geopolitical spread of American AngloSaxonism (Horsman 219). Accordingly, Kaplan identifies the paradox of America's exceptional nature "in its exemplary status as the apotheosis of the nation-form itself and as a model for the rest of the world. American exceptionalism is in part an argument for boundless expansion, where national particularism and international universalism converge" (16). Imperialist discourses, like the inseparable discourses of Manifest Destiny and domesticity, "share a vocabulary that turns imperial conquest into spiritual regeneration in order to efface internal 
conflict or external resistance in visions of geopolitical domination as global harmony" (Kaplan $31)$.

Early national and antebellum imperialist discourses of spiritual regeneration were fundamental to the redeployment of a reinvigorated white Protestant nationalism in the mid 1860s and, consequently, to the renewal of American imperialism in the wake of Reconstruction. Blum argues that "religious rhetoric and metaphors also played key roles in literary and political calls for reconciliation, permeating a broad 'culture of conciliation.' Writers and politicians, including the eccentric editor and presidential candidate Horace Greeley, regularly cloaked reunion in sacred garb and claimed that God ordained solidarity among whites" (13). Discourses of spiritual regeneration, then, worked to rationalize and to enable Northerners' abandonment of their civic responsibility to freedpeople in the South as well as in the North. Overriding the more sectionally divisive push for racial uplift, religious leaders promoted white racial unity in place of (and disguised as) national reunification. This rejuvenated rhetoric of white Protestant nationalism, derived from early national providentialism and the antebellum providentialism of Manifest Destiny, "played a vital role in the rise of the American global empire in the 1880s and 1890s. National reconciliation at home and imperial efforts abroad had a dialectical relationship. Reunion enabled the United States to focus its energies on foreign lands and in turn created stronger feelings of national identity at home, and northern white Protestants were pivotal in the outward and militaristic thrust of the nation" (Blum 16).

In a novel that, like Twain's Connecticut Yankee, imagines a sort of internal imperialism in which the tensions between expansionist narratives of progress and the violent divisions they engender are doubly present, Griggs engages with similar internal divisions within black America. In the late nineteenth century, Tunde Adeleke observes, more militant black 
nationalists and Pan-Africanists pursuing "their schemes for the freedom and elevation of fellow blacks and Africans" also "displayed ideological ambivalence by embracing the ideals of the dominant Euro-American culture against which they (especially Delany and Turner) professed to be struggling" (10). These radical race men shared with their more moderate contemporaries at least a partial subscription to white narratives of civilizing progress. As Michele Mitchell contends, "at times, even anti-imperialist blacks all but suggested that some form of civilizing conquest was necessary if Africa ever hoped to keep apace with Europe, North America, and Asia" (56). African Americans were, like whites, ideologically divided along unstable class lines. In the violent context of Jim Crow, "aspiring and elite men were likely to feel that their hard-won gains were slipping away," and even those who opposed expansionism "relied upon a trope of manhood constructed around race, as did men who believed class mobility could be best achieved outside U.S. borders" (Mitchell 56). For black men as well as for white, this imperialist moment exposed a distinct clash between ideal notions of class mobility and racial and national agendas.

Rather than simply focusing on the best route for black resistance or black nationalism to take, Imperium in Imperio addresses the apparent dualism of militant and accommodationist strategies of black resistance to white supremacist oppression. Representative of apparently irreconcilable dogmas, "militant” figures like Martin Robison Delany, W. E. B. Du Bois, and Malcolm X have been consistently paired by historians and cultural critics alike with their more moderate contemporary counterparts Frederick Douglass, Booker T. Washington, and Martin Luther King, Jr., respectively. Washington and Du Bois were both complex thinkers, but they were soon perceived to represent clearly defined and opposing positions—and they found themselves performing these roles. As Adeleke contends, "Black Americans generally longed to 
be identified and accepted as Americans. This explains why, for much of the eighteenth and nineteenth centuries, black American nationalists, and indeed, black American leaders in general, regardless of ideological disposition, espoused integrationist aspirations and values" (2). Despite marked and complex ideological positions, African American leaders "combined feelings of alienation and deprivation with faith in classic American middle-class values of industry, thrift, and economy" (Adeleke 2-3). The challenge for race leaders at this time was to negotiate their exclusion from and simultaneous subscription to American ideals of representative freedom, sovereignty, and exceptionalism.

Imperium's Bernard Belgrave and Belton Piedmont may appear to represent ideologies similar to those of Du Bois and Washington, yet Griggs is careful to represent the complexity of their positions as well as the significant constraints imposed upon black leadership by the parasitical nature of white freedom. Like Twain's Connecticut Yankee, Imperium in Imperio does not reach a satisfactory solution to its narrative conflicts, nor does it offer adequate alternatives to the status quo. Imperium in Imperio explores the evolution and effectiveness of both conservative and militant responses by the black community to white supremacist oppression in the late nineteenth century. The story unfolds via the parallel lives of the novel's dual protagonists, light-skinned and affluent Bernard and his dark-skinned and impoverished counterpart, Belton. Friends and rivals since childhood, Bernard and Belton are reunited as adults after Belton miraculously survives an attempted lynching in Louisiana and subsequently murders the white eugenicist doctor as he prepares to dissect Belton's apparently lifeless body. Belton escapes, then calls on Bernard, an accomplished lawyer, to defend him before the Supreme Court. This encounter leads to Bernard's unanimous election as the first president of the Imperium in Imperio, a secret African American government operating parallel to the US 
government and established via the union of those "secret orders already formed by negroes" (Griggs 132). Griggs eventually pits Belton's conservatism against Bernard's militancy in a final oratorical showdown over the proper usage of and response by this well-funded and unified black organization. The novel ends with Bernard's resolutions — which include the Imperium's infiltration of the US Navy, formation of secret alliances with foreign enemies of the US, and seizure of the Texas capitol—adopted by the members of the Imperium but not yet set in motion. Belton, for his dissension, is executed by a firing squad made up of members of the Imperium and commanded by Bernard (173-174).

Griggs is perhaps best known for Imperium in Imperio despite the fact that his first novel, as Finnie D. Coleman has convincingly argued, represents the early conceptual stages of what would become Griggs's signature uplift philosophy. Over the next thirty-four years, Griggs wrote four more novels and numerous political pamphlets in which he developed and revised his science of collective efficiency, which was, according to Coleman, "a commonsense approach to racial uplift, social mobility, and political activism” (109). Griggs subsequently wrote Overshadowed: a Novel (1901), Unfettered, a Novel (1902), The Hindered Hand; or, The Reign of the Repressionists (1905), and Pointing the Way (1908). Two of these novels included supplementary non-fiction material. Dorlan's Plan (Sequel to "Unfettered": a Dissertation on the Race Problem), in pamphlet form, was appended to Unfettered, and The Hindered Hand included A Hindering Hand; Supplementary to the Hindered Hand, A Review of the Anti-Negro Crusade of Mr. Thomas Dixon, Jr., an open letter written by Griggs in response to The Leopard's Spots (1902). According to Coleman, "reviews of [The Hindered Hand] and praise for the supplement suggested to Griggs that there was a market for his political writings independent of his fiction" (117). Griggs went on to write many more pamphlets and political tracts, including: 
Wisdom's Call (1910), his first book-length political work and a collection of excerpts from his earlier pamphlets; The Story of My Struggles (1914), a uniquely personal and autobiographical text; and The Science of Collective Efficiency (1921), which sets forth Griggs's personal and political doctrine of pragmatic black uplift and collective self-help. In The Guide to Racial Greatness; or, The Science of Collective Efficiency (1923), Griggs combines his "philosophy and a methodology for accomplishing Black uplift" (Coleman 127).

Griggs works to identify and illuminate the problems his community faces in their efforts to become an outwardly recognizable community and to represent the processes by which any efforts toward black resistance have been shaped and constrained by ideologies of white freedom. Belton has been influenced by the narratives of "Tourgée (and, of course, a host of other contemporary writers, black and white)" and, consequently, as Schmidt suggests, "Belton assumes that Africa embodies savagery. He suggests that the horrors of the middle passage and slavery and war had one saving grace - the American descendents of Africans now have access to the English language and European Enlightenment arguments for liberty and equal rights" (76-77). Whereas Belton has absorbed one version of a fractured American cultural narrative, Bernard has internalized yet another version of the same narrative. Despite his best efforts, "Bernard's Imperium ironically comes to mirror the obsessions of another invisible empire, the Ku Klux Klan. Bernard's methods of combating white supremacy lead him to adopt its nationalistic rhetoric of violence and also its determination to keep free of pollution the racial and cultural purity of the black body politic" (Schmidt 78). Although their methodologies differ, Griggs suggests that Belton and Bernard ultimately want the same thing - a thriving and unified black nation modeled on or absorbed within an idealized white America. 
Griggs's challenge, then, as a novelist and as a political philosopher, is to find a way to cast black freedom in terms independent of white supremacy, or, perhaps, to conceptually modify the processes of the existing social order. His refusal to propose a clear resolution to his novel or to openly support either of the positions represented by either Bernard or Belton characterize Griggs's denial of the compartmentalized categorical responses made available to him within a white supremacist culture. Gloria T. Hull suggests that Imperium in Imperio, like Delany's Blake (1859-62), is “at least partially fulfill[ing] the methodological requirements for socialist realism," because both Imperium in Imperio and Blake only partially fit within the parameters of this genre as Hull defines it. Delany "leaves [his revolution] in progress" and Griggs's "secret, elaborately-organized black 'nation within a nation"” is still "steadily transforming American society." While both novels "go beyond critical realism to a more detailed depiction of the revolutionary struggle," they stop short of "a confident portrayal of the future society" (151). It is perhaps this stopping short which leads Kali Tal to argue that Imperium "reflect[s] a profound pessimism about the possibility of achieving justice and equality 'within the system"” (67) and prompts Coleman to suggest that Imperium is "an intellectual call to arms" (58) but one with a "rhetorical strategy [which] proved to be extremely problematic" (69). ${ }^{34}$ Each of these critics suggests, at least on some level, that the betrayal of the Imperium's revolution at novel's end represents a deficiency in Griggs's political philosophy or in the plot of his novel, whether a metaphorical throwing up of his hands or an ambitious but somehow aborted political undertaking. As readers invested in the outcome of the epic confrontation we've been led to expect, we want to see the conflict through to its resolution. Also conditioned by the riotous presence, readers expect to see the cycle play itself out so that it can begin again. The text's complex set of frames instead suggests that Griggs may have been committed to an 
affirmative denial of the options available to him, that the ending is less of a non-ending than the act of seeking of a wholly different sort of ending.

Although the fate of the Imperium is left hanging in the balance at novel's end, Griggs stakes a powerful claim to a revised national narrative by virtue of his novel's double frame. As Coleman observes, "signifying on the politics of the authorizing preface, Griggs speaks himself into his text and his text into being by doubly framing what is already a framed text" (44). In this way, Griggs positions himself as authoritative narrator in the spirit of white authenticating prefaces appended to antebellum slave narratives, poetry, and even novels by African Americans. "When Griggs sent Imperium in Imperio to the Editor Publishing Company in 1899, he refused to have his authorial presence spoken into being by a White editor" (Coleman 44). Griggs's rebuff is all the more significant in the revolutionary context of Imperium's plot. Claiming for himself narrative autonomy and political autonomy as well, he refuses to have his African American revolution sponsored by a white benefactor. In other words, he refuses to play Jim to an editorial Tom Sawyer. Such an endorsement, or authentication, would undermine the political thrust of his novel and of his racial uplift philosophy. If Griggs were to welcome a white patron into the fold, it would not have been the mere narrative for which the white sponsor spoke, but the revolution itself, constituting a veritable request for white leadership and reinforcing white ideologies of independence. Despite what remains a problematic authorial intrusion into his own novel, Griggs's self-implicating framing device does doubly play on his revision of the nation's split beginnings and, accordingly, the pursuant national and historical narratives that will shape its future.

Even more poignant than his self-authenticating preface is Griggs's postscript entitled "Personal (Berl Trout)" (175). In this brief first-person postscript, Trout, a character in the novel 
and a confessed member of the Imperium, voices his remorse for his own part in Belton's execution and his fear for the future of the Imperium with Bernard as its leader. In his closing admonition, Trout bemoans the loss of Belton as a political leader for the African American community: "When he fell, the spirit of conservatism in the Negro race, fell with him. He was the last of that peculiar type of Negro heroes that could so fondly kiss the smiting hand" (175). On the other hand, Trout proclaims that "born of distinguished parents, reared in luxury, gratified as to every whim, successful in every undertaking, idolized by the people, proud, brilliant, aspiring, deeming nothing impossible of achievement, with Viola's tiny hand protruding from the grave pointing him to move forward, Bernard Belgrave, President of the Imperium in Imperio, was a man to be feared" (175). With Trout's exaggerated distinctions between these two polarized leaders, Griggs mobilizes the alternating discourses of sycophancy and brutality that limited the political options of black leaders.

Importantly, Griggs illustrates that men like his contemporaries Washington and Du Bois, like Belton and Bernard, are performing their respective roles according to the limitations of a white supremacist culture and the American ideologies of white independence that even they subscribe to on some level. Even as Belton's accommodationism appears to compromise the integrity of a race, it also represents an abstract and imperfect spirit of compromise and heterogeneous group subjectivity that is necessary somewhere, in some way, if the cycle of violence is ever to be broken. Belton appears to be succeeding to the secondary role proscribed for him within white narratives of white freedom while Bernard's projected internal invasion of the white US represents, in contrast, a more aggressive, individualist push for independence. Bernard and the others are so caught up in their refusal to be subjugated that only Belton seems 
to recognize the fatal flaw in Bernard's plan: violent revolt does not so much defy white supremacy as it replicates it in different, similarly destructive terms.

Trout's ultimate act of betrayal, in which he reveals the existence of the Imperium, presumably to members of the white national government, is not necessarily evidence of the failure of the Imperium as a political project or of the failure of Griggs's revised national narrative. "With Belton gone and this man at our head, our well-organized, thoroughly equipped Imperium was a serious menace to the peace of the world. A chance spark might at any time cause a conflagration, which, unchecked, would spread destruction, devastation, and death all around," Trout writes by way of explanation for his traitorous act (176). On the surface, Trout's act appears to be one of concession, particularly as he hopes that because of his revelation the Imperium "might be broken up or watched" (176). However, given Griggs's multiple frames, Trout's confession is equally evidence, provided for the benefit of both his white and black audiences, of how precarious this balance between peace and devastation truly is, and of how heavily that balance depends on the good faith of both conservative and more militant African American community leaders. Should the white community fail to appease more moderate black leaders like Belton, those same leaders will lose the trust of their communities and be replaced by men like Bernard, who will not be so eager to compromise. 


\section{Rumor, Race War, and The Specter of Cooperative Democracy}

Democracy has become the goal of our age. But not all men as we find them in the world today are able to conduct a successful democracy. This is possible only where there is a sufficient preponderance of certain traits and the following out of certain principles. Without the necessary traits and principles a group may have the form of a democracy, but it will be but a hollow mockery.

- Sutton E. Griggs, Foreword to Guide to Racial Greatness; Or, The Science of Collective Efficiency

As Twain does in Connecticut Yankee, Griggs modifies the thrust of nineteenth-century Anglo-American imperialist narratives, but he does so by conceptualizing an African-American racial-national exceptionalism in terms similarly reliant on the tempered success of the American Revolution. Where Twain's reversal in Connecticut Yankee is both geographical and temporal in that American exceptionalism turns back on the "mother" country and its glorified past, Griggs's inversion is also geographical in that it predicts a foreign invasion of American soil from within. Not coincidentally, it is the prior Republic of Texas that is to become an independent republic once again in Griggs's Imperium. Where Twain's Connecticut Yankee looks to the past as ultimately changed by and dependent upon the future, Griggs looks to the future as he rewrites a distinctly Anglo-American historical narrative of democratic idealism as Afro-American and recasts the future of the nation as a result. Griggs's novel, in fact, anticipates and complicates Twain's later rhetorical construction of two Americas. This doubling, for Griggs, occurs equally within white America's incongruous extension of cherished democratic ideals and within the internal division between black and white America.

In its replication and attempted reparation of the structure of ideal constitutional democracy, the Imperium reflects the violence of white American structural principles. As Coleman intimates, the militancy of Griggs's novel was not in his advocacy of a military solution to the "race problem" but in the suggestion that one of the "options offered to White America ... 
included the possibility of violent reprisal" (70). The options outlined by Griggs are merely those dictated by the riotous presence, and he is careful to illustrate how that would likely play out. "The militancy that so many critics have rightly focused upon in the novel," Coleman insists, "derives from the fact that Griggs offers solutions that require mainstream America to make a choice: either relinquish the rights and privileges that accrue to all Americans and live in peace, or maintain the status quo and risk all-out war" (70). Essentially, Griggs poses the same questions with which Bernard and Belton grapple for white Americans. Once qualified independence is achieved via violent revolution, are we willing to maintain our sovereignty through more violence? Or is there some other way to effect revolution in which underlying and faulty ideology is fundamentally disrupted? In creating his Imperium, Griggs exploits a contemporary version of a rumor which arose during slavery and persisted into the postbellum world - that slaves or oppressed blacks would (rightly) rise up against their white oppressors and not simply rectify but completely reverse the social order and the relations of master and slave.

This historically persistent rumor of impending insurrection took on new significance in the summer and fall of 1865 , just months after the official end of the Civil War, when "mutually reinforcing rumors of a world turned wholly upside down either by federal government fiat or armed black insurrection" circulated among blacks and whites in the rural South (Hahn 128). These rather vague and general rumors were predicated, for both blacks and whites, on the knowledge that freedmen and women now vocally expected to be compensated for their laborif not for the labor they had already provided as slaves, then for their subsequent labor as tenant farmers, sharecroppers, and independent artisans. Freedmen claimed that they were entitled to Southern land bought with the proceeds from the sale of generations of their own families, the land they had worked with their own hands and backs, the land by which their labors had 
produced the commodities that sustained consumers in the North (Hahn 135). Such veritable demands for compensation violated the seemingly inviolable genteel hierarchy of race relations in the South. The more disturbing feature of the freedpeople's claims for many whites, however, was that their collective actions "demonstrated that slaves had become familiar with and could appropriate a powerful, if contested, national political discourse that exalted manual labor and associated freedom with economic independence" (Hahn 135). That white southern planters as well as ex-slaves expected something to happen by the end of the year, whether significant government interference or a widespread uprising, suggests that planters at least subconsciously understood that the freedmen's appropriation of this political discourse exposed the planters' own hypocrisy and the insincerity of white Americans who openly claimed or merely enjoyed the privileges of whiteness.

Many white southerners initially feared that the federal government might seize their lands and redistribute them among the freedpeople who had worked them during slavery, or that the government would endow each family with "forty acres and a mule," as many blacks expected. ${ }^{35}$ However, by September it had become clear that those white officials who would fight for the division and redistribution of Confederate lands made up a radical minority. Most white southerners now overwhelmingly declared a fear that "disappointed freedpeople" would "take matters into their own hands by the only means left available: concerted violence" (Hahn 146). While blacks generally expected some sort of meaningful change to occur by Christmas, whites marked this same holiday as the point by which disgruntled ex-slaves would rise against their former masters, instigating 'a race war, 'a negro Jubilee insurection,' [sic] when the exslaves, reenacting the 'horrors of Jamaica and St. Doming,' would attempt to murder or drive off their former masters" (Hahn 128). The protracted affair would come to be known as the 
Christmas Insurrection Scare of 1865, which in terminology and in dominant historical memory rhetorically and conceptually reduced (and continues to reduce) freedpeople to their former status as slaves. White southerners' use of the term "insurrection" to describe the anticipated result of widespread tensions and anxieties between and among blacks and whites even after Emancipation discursively reasserts southern whites' claims to national and governmental authority. In the aftermath of the Civil War, whites of both regions were conceptually realigned in terms of their collective classification of and opposition to black "insurrection," or, more accurately, the assertion of black claims to economic and political independence.

Vague and unsubstantiated rumors of land distribution resonated much differently within the African American community but in ways that significantly ran parallel to their trajectory through the white South. As Hahn observes, "the rumors, the 'extravagant' ideas of what freedom might bring, that is, played a significant role in defining the political communities of rural blacks newly emerged from bondage" (135). For whites, these rumors inspired increased aggression and vigilance against measures of black economic and political progress, which in turn promoted the inevitability of violent black uprising. These same rumors served as points of communication for dispersed blacks, and, more importantly, "as safer ways in which to introduce themselves as political actors; and as potent means for shaping-and advancing-the terrain of political debate" (Hahn 135). Whether or not the rumors of property distribution would turn out to be true, they had thrown the white folks into a frenzy and provided the freedmen with a basis for increased expectations and demands in terms of labor, mobility, and compensation. Upon the expectations and demands grounded in these rumors, freedpeople built a community of resistance. Many refused to sign contracts with planters until after the first of the year, thereby pressuring some planters to offer better terms in order to keep existing laborers working or to 
attract new workers. Widespread refusals by freedmen to enter into contracts disrupted the existing labor system in the rural South and, in many ways, freedpeople's collective belief in or manipulation of the Christmas rumors served to give them an upper hand in contract negotiations.

That the fears of many whites ran directly to insurrection and the complete reversal of existing power structures illustrates how conceptually impossible it was for them, even those who did not approve of physical violence against blacks, to envision a negotiation or a more balanced restructuring of labor and political relationships so that freedmen might be granted not total domination but more balanced access to the promises and practice of US American citizenship. The parasitical nature of white freedom, the foundational idea that freedom must be hierarchical and that there must be some identifiable other by which to gauge, measure, and enact independence, defines the parameters of white resistance to the upward mobility of exslaves. These rumor cycles illustrate the tenuous stability of such a flawed social structure, and they also speak to a missed opportunity in the pivotal moments following the end of the Civil War.

Writing for multiple audiences simultaneously, Griggs enacts a version of the same rumor cycle that fueled expectations of Christmas riots in 1865, drawing on the mobilizing potential of white political repression and politically-motivated violence against blacks. The very existence of the Imperium in Griggs's novel capitalizes on white assumptions that African Americans and African-American subversives are withholding vital information from whites generally and white authority figures in particular. This secret government, formed in response to the failure of the "General Government" to "protect the negro in his rights" (132), also recognizes the Imperium as a necessary reaction to their own exclusion from the fold of the 
"General Government." Griggs's declaration that this failure results primarily "because of a defect in the Constitution" (132) — the ultimate American national narrative-implies that the Constitution itself is a document of secrets, not to be taken at face value. In setting up such a complex and elaborate binary, Griggs taps into the political power inherent in rumors born of civil division and dissension to dramatize what it might look like—-for blacks as well as for whites - if the worst, and perhaps consciously unacknowledged, fears of the most virulent white supremacists actually came true. Griggs's Imperium is not riot at all but the longstanding, wellfunded, hyper-vigilant, hyper-organized, and thoroughly disciplined reflection of everything that the US government purports to be in theory but in actuality is not—at least as long as the Imperium remains a closed secret. With the Imperium, as with the historical Revolution on which it is modeled, the latent possibilities are greater than the realization.

The conflicts and pending resolutions set forth in Imperium in Imperio are firmly rooted in the material world of the late nineteenth century, which provides a basis for the novel's disruption of Anglo-American inheritance myths dating to the American Revolution and beyond. In Griggs's fictional world, the Imperium has "wisely invested" money donated to the organization by its founder, an independently wealthy "negro scientist" and author who lived "in the early days of the American Republic" (130). The Imperium has increased its wealth, through the apparently covert purchase of land and the collective earnings of its citizens, who "own about $\$ 350,000,000$. And all of this is pledged to our government in case it is needed" (133). All told, the Imperium has access to $\$ 850,000,000$ for "secur[ing] the recognition of the rights of our people" who are "determined to be free and will give their lives, as freely as they have given their property" (133). The wealth of the Imperium has clearly been earned via the backbreaking and bloody work of African American slaves and painstakingly saved despite efforts by white 
masters, and later white employers, to render any meager payment they might receive for their labor void through trickery or compulsion. In this way, the legacy of the Imperium and its ideology of independent resistance reflects white Revolutionary ideologies and the building of a white nation on the labor and moral superiority of its citizens. However, despite the fact this subversive network has collected substantial resources and virtually surpassed the mainstream government on which it is modeled, material wealth cannot effectively undermine dominant ideology.

Griggs's repeated references to the historical lynching of black postmaster Frazier Baker point to the incongruence of economic opportunity and white supremacist ideology within American culture. While quantifiable prosperity and social mobility are for white Americans a direct effect of their successful Revolution, the same upward struggle and tangible achievement for black Americans is grounds for violent retribution. Baker is represented in Griggs's Imperium by the fictional character Felix A. Cook, "a colored man of ability, culture, and refinement" who was appointed postmaster of Lake City, South Carolina, by President McKinley (137). The fictional Cook is brutally murdered, his home is burned, and his wife and children are horribly injured, all because local whites object to his acceptance of the coveted position of postmaster (138). Griggs returns again and again to the Cook family's tragedy in the final chapters, emphasizing the frequently fatal consequences for African Americans who pursue the sort of gainful employment and economic independence that has traditionally been reserved by whites for whites. Griggs reiterates the fact that Baker's commendable struggle for economic success does not fit within cherished narratives of white freedom. In his efforts to cast his own lot in those terms, Baker is brutally rebuked, as will be other black Americans who try to access their 
own freedom within the parameters set by cherished white narratives of rugged individualism and perseverance.

In constructing his Imperium, Griggs elevates the underlying rumors of political dissent that plague American national narratives of democracy and union to a position of prominence. He restructures the ongoing conflict between white and black, generally represented as a mere quarrel between masters and slaves, as a war between nations, thus anticipating his own developing philosophy of pragmatic racial uplift. "When one race moves in to administer affairs which another race feels should be under its jurisdiction," Griggs argues in Guide to Racial Greatness, "there is an inevitable clash of spirits between the two" (30). As Griggs makes clear, this "inevitable clash of spirits" is, at least in part, exacerbated by perceptions of weakness: "The group unable to avail itself of its material resources is often likewise unable to maintain law and order, or to conduct a progressive civilization. This weakness invites aggression even as sores are a standing invitation to flies” (30). In Imperium, Griggs recasts African Americans as an independent nation, nearly as old as the US, and more efficient to boot, thereby working to alleviate dominant white assumptions of racial and political weakness among African Americans as a group. Because white America assesses political and social value in terms of material wealth, and, more importantly, because the acquisition of material wealth, the proceeds of their own labor, and access to natural resources have been categorically denied African Americans by whites under the rubric of democracy, Griggs constructs his potential uprising in just those terms.

Although Griggs's initially favorable reception by the black intellectual community based on Imperium in Imperio's "militant radical plot" eventually turned to open criticism of his perceived accommodationism, contradictory acceptance of black inferiority, and insistence on the accountability of black leaders for "failures in the Black community" (Coleman 25; 124), 
Griggs maintains in Guide to Racial Greatness an emphasis on the importance of leadership as representative of the people. A considerable part of this responsibility, according to Griggs, lies with the people themselves: "It is a joint task for a group to get its consensus of opinion up to those in charge of affairs, so as to enable those in authority to note the effect of things that are done" (15). In the context of Griggs's novel, this mandate has dual significance for the Imperium and for the white US government. The text of the novel asserts that it is the Imperium's duty to communicate with and to impress upon the national government their dissatisfaction with the status quo, of which they prove themselves more than capable. The postscript, however, implies that Belton no longer represents the interests of the Imperium as a majority, so they have, functioning effectively as a group, removed him from his leadership position. Griggs is equally adamant in Guide to Racial Greatness that one of the joint tasks required for functional collective efficiency is "the deposing of unworthy leadership" (16).

Despite its controversial and arguably convoluted ending, Griggs's Imperium in Imperio insists on an alternative narrative of American history and American politics of which both Belton and Bernard are part. Respectively representative of conservatism and militancy, Belton and Bernard are polar opposites in terms of their skin color, economic status, oratorical style, and especially their politics, yet both exist only as the inverse of the other. Griggs's narrative is about this interdependency within the contemporary black community, just as it is about African American history, military revolution, or mob violence. In the same vein, Imperium painstakingly reveals the interdependency of a white US American body politic and the lives and labors of black Americans. The alternative government that Griggs creates is not meant to stand alone, as Trout's betrayal suggests, and such an amputation is ultimately impossible. The Imperium exists within and as the inverse of white America, but neither can exist independently 
of the other. What is true for governments is also true for the narratives that write them into existence, which define national identities and reflect the subjectivities of citizens. Griggs's narrative endeavors to become a part of, to shape and to change, a standing US American national narrative, but to do so on his terms. Griggs's narrative is the subversive, insurrectionary rumor that runs apparently contrary to national myths of democratic citizenship, but it is also the harbinger of compelling plausibility.

If Griggs's science of collective efficiency is a directive by which to build and perfect an independent, cohesive, and politically successful African American community, Guide to Racial Greatness can also be read as a subversive document detailing a strategy for the destruction of white supremacist hegemony from within. Individualism, Griggs asserts, is the destructive doppelganger of the group. "The Individualist," Griggs argues, "is so sure that his tubercular viewpoint of life is right that to him an altruist is either a rank fool, or some one merely posing as having an interest in society superior to his interest in himself' (44). This missive serves as a warning for black communities like the Imperium in Imperio and promotes Griggs's general argument of individualism as contrary to group efficiency and the completion of joint tasks. However, Griggs provides an alternative scenario in which he describes the difficulties of operating within an individualistic group. "Behold then," Griggs writes, "the fate of a man of exceptional strength in the midst of an individualistic group. His first battle is with the jealousies of those who themselves would like to sit in the seat of power" (56). While Griggs speaks here about group membership in broad terms, he seems to be speaking not to African Americans or to white supremacists but to potentially subversive whites who might, with a little support, be inclined to defy cultural norms in support of a more coherently unified subjectivity. "But, in groups where individualism prevails, the neutrals who constitute the overwhelming masses, and 
who could determine issues, often are so engrossed with their individual tasks as to leave the exceptional man to battle single-handed with those contending with them. In the co-operative groups where the units have acquired the habit of throwing themselves into the tasks of others, they go to the rescue of the exceptional character" (56). This could easily be an invitation to dissenting whites to defect from the dysfunction of white supremacy and join ranks with a new and integrated "co-operative" community, where exceptional character and commitment to ideals, rather than neutral maintenance of the status quo, will be nurtured and appreciated.

Despite trafficking in the fantastic and looking forward to significant social transformation, both Twain and Griggs situate their cultural criticism squarely within the problems of history. Like Griggs's Imperium, Twain's Connecticut Yankee plays into and makes use of an ongoing culture of rumor/fear that is immediately linked to the potential for underclass acquisition of property and the ruling class' understanding that this acquisition equals their own loss of property and therefore wealth, comfort, and power. The prevailing feeling among whites in the late nineteenth century, as evidenced by the majority's conceptual leap from labor unrest among black workers to armed insurrection, was that loss for one group equals gain for another, and vice versa, so that it is a cultural impossibility to conceive of material, political, or personal gain for a previously oppressed group as just that. A legacy of American racial slavery is that social balance comes to be seen (by whites and blacks alike) not as the equitable division of property and power between citizens of all stripes but as a limited amount of property and corresponding power which is passed back and forth between members of different groups, consequently tipping weighted scales for or against. In this formulation, gain for one is always loss for another and can be seen in no other way. 
This is the underside of the national narrative, Twain and Griggs reveal, the complicated interdependency of gain and loss, of conqueror and conquered, and its intersection with raced and gendered "bootstrap" narratives of class transcendence. These fundamental fractures portend violence again and again, in each new manifestation and in each new conscious reworking of the system. Warning against the dangers inherent in trying to recreate a people's revolution — the dangers of recreating the same failures, of falling into the same traps, of displacing the same fundamental human elements - Twain and Griggs suggest that the violence of imperialism, of capitalism, of lynching and of riot is insurmountable within the context of standard narratives of progress and civilization. In constructing actual or imminent violent revolutions in terms of the subversive community's ability to undermine an oppressive culture's sense of security, Twain and Griggs suggest that the terror of white supremacy is insidious, self-replicating, and adaptable to different cultural moments.

Notes to Chapter 4

${ }^{30}$ Martin Luther King, Jr., Where Do We Go From Here: Chaos or Community? (Boston: Beacon Press, 1967), p. 112.

${ }^{31}$ See Gossett, Race: The History of an Idea in America, pages 287-309 for a survey of positions within the immigration debate.

${ }^{32}$ Originally published in the North American Review, February 1901.

${ }^{33}$ Frederickson credits Ray Stannard Baker's Following the Color Line (New York, 1908) as his source for this quotation. For more on the 1906 Atlanta race riot, see also Mark Bauerlein, Negrophobia: A Race Riot in Atlanta, 1906 (Encounter Books, 2001).

${ }^{34}$ In defining a genre which she terms "black militant near-futurist fiction" (74), Kali Tal considers Imperium in Imperio alongside George Schuyler's Black No More (1931) and Black Empire (1936-1938), John A. Williams's Sons of Darkness, Sons of Light (1969) and Chester Himes's Plan B (1968-1983?), texts which, Tal argues, commonly "present the argument that African Americans must revolt or succumb to slow death at the hands of their 
oppressors. Each features a secret society of dedicated revolutionaries, a charismatic leader or genius, a face-off between those blacks who advocate violence and those who cannot bring themselves to do so" (67). Black militant near-future fiction is decidedly secular, as opposed to black near-future fantasy, which Tal describes as "distinguished from science fiction because it relies on supernatural or metaphysical means to achieve its ends" (76). Black near-future fantasy, in which Tal includes Ishmael Reed's Mumbo Jumbo (1972), Toni Morrison's Song of Solomon (1977), and Toni Cade Bambara's The Salt Eaters (1980), emphasizes spirituality; “The genre of black militant near-futurist fiction, however, is built upon the renunciation of that spirituality and belief in magic" (76). The distinction Tal draws here is significant, because Imperium in Imperio, like Connecticut Yankee, is situated entirely within the material world and draws on a combination of Enlightenment ideals and nineteenth-century techno-bureaucracy for its revolutionary solutions.

${ }^{35}$ In Reconstruction, Eric Foner suggests that William T. Sherman's "Special Field Order No. 15" is perhaps the origin of the widely-circulated "forty acres and a mule" phrase. Sherman's order provided for the setting aside of a tract of land in the South Carolina low country exclusively for black settlement. "Each family would receive forty acres of land, and Sherman later provided that the army could assist them with the loan of mules" (Foner 70). As Foner makes clear, Sherman's provisions were only intended to be temporary, a response to "the immediate pressure caused by a large number of impoverished blacks following his army" (Foner 71). 


\section{Coda. Meditations on An Activist Agenda}

Those who make peaceful revolution impossible will make violent revolution inevitable. --John F. Kennedy, 1962

In his introduction to Robespierre's Virtue and Terror, Slavoj Žižek suggests that true egalitarian revolution cannot exist independent of terror. In order to resist losing the momentum of revolution within the "abstract terror" of "the "big' political revolution," the moment of revolution must be followed by "the 'concrete terror' of imposing a new order onto daily life" (xxxvi). In other words, revolution must be a radical reversal of the status quo in which an egalitarian dictatorship - "the 'dictatorship of the proletariat' is another name for the violence of the democratic explosion itself" - must be maintained via terror. "The 'dictatorship of the proletariat"” Žižek explains, "is thus the zero-level at which the difference between legitimate and illegitimate state power is suspended, i.e. at which the state power as such is illegitimate" (xxx). Žižek contends that rather than humanism or terror, where humanism is the positive term, or humanism and terror, with each either positively or negatively perceived, the only viable choice is "'humanism or terror,' but with terror, not humanism, as a positive term" (xiii). "This is a radical position difficult to sustain," he admits," but, perhaps, it is our only hope: it does not amount to the obscene madness of openly pursuing a 'terrorist and inhuman politics', but something much more difficult to think through" (xiii).

Fundamentally, my own concern with popular and historical differentiations between legitimate and illegitimate violence mediated within the language of democracy is grounded in my desire to pursue an activist agenda, not merely to meditate on the past but to offer new perspectives for reflecting on the present and on possibilities for shaping a better, more egalitarian future, ideally a future in which the state does not govern by force, threats, or 
violence. It did not occur to me at the outset that I might find some, if not all, of the answers for which I had been searching in Žižek's formulation of terror as a means to a true humanism that empirical democracy, by its very nature, renders impossible. This coda, then, is not a manifesto, and it is not a call to arms. It is, however, a somber reflection on the conceptual and practical differences between true radicalism and liberal humanism, terms that are often, and dangerously so, synonymous in the rhetoric of the conservative Right as in the language of the moderate Left.

In thinking through my own driving questions, I have also been, in terms similar to Žižek's, thinking through a radical revision of the relationship between terror and democracy, of the place of one within the other. Early in my writing process a friend from a different university, who also works on terror and its relationship to democracy and the state, read a draft of my first chapter at my request. Afterwards, she poignantly asked whether I was advocating or opposing violence as a legitimate form of resistance against oppression (state or otherwise). At the time I was not impressed by this question. It felt like an oversimplification of my work and of the very conflicts and inconsistencies I was working to complicate with my analyses. In the months that followed, however, this question haunted me. Was I advocating violent resistance? I wanted to think of myself as an activist, as someone who worked for peace. But could peace ever be implicit in violence? Or, on the other hand, was violence necessarily implicit in peace? In promoting a discourse of differentiation between the normative violence of the state and the unsanctioned violence of an oppressed minority, I was indeed suggesting that some violence was legitimate — slave insurrections, for example — and some violence — imperialism, slavery, lynching, white riots - was oppressive. In short, I was in danger of replicating the very language I wished to demystify. At the same time, the last thing I wanted to do was to elide the differences between the violence of the oppressed and that of the oppressor. My friend had asked a smart 
question after all, as she usually does, and the fact that I couldn't immediately answer it troubled me.

I do not now mean to intimate that I have reached a satisfying conclusion or that I have formulated a plan for gleaning lasting peace from an inherently violent society. What I do want to suggest, as I reflect on what I have written in these pages, is that the very functional, structural nature of ideal representative democracy and liberal humanism do make arguments like Žižek's both necessary and plausible. American Democracy, as a political system, is not the same as egalitarianism, although this is what many of us have been led to believe. In fact, the empirical nature of democracy presupposes hierarchy. "In the cruelest of ironies," Andy Doolen asserts of America's national foundation, "the American rhetoric of equality was articulated not simply over and against an imperial logic of racial domination, but within that very logic. In the new republic, whiteness declared independence, using terror as its founding vocabulary" (xvi). Within the framework of Žižek's claims, Doolen's observation suggests that white supremacy has embraced terror as a means to maintaining a certain kind of "democratic" social order based on hierarchical exclusion in which democracy itself is normative. "Paradoxically," Žižek argues, "the underlying premise of democracy is thus not only that there is no political agent which has a 'natural' right to power, but, much more radically, that the 'people' itself, the ultimate source of sovereign power in democracy, does not exist as a substantial entity" (xxxii). Even in a properly functioning voting democracy, there will always be a minority who "are not simply a minority: in learning the result of the vote (which runs against their individual votes), they do not simply learn that they are a minority — what they learn is that they were mistaken about the nature of the general will" (xxiii). 
In the context of American white supremacy, Žižek’s evocation of a minority who are not just a minority turns basic assumptions about the nature of democratic practice on its head by positing the minority as acquiescent to a normative system of inequality. Following Robespierre, Žižek explains that

Every legal order (or every order of explicit normativity) has to rely on a complex 'reflexive' network of informal rules which tells us how we are to relate to the explicit norms, how and when we are allowed, solicited even, to disregard them, etc. - and this is the domain of habit. To know the habits of a society is to know the meta-rules of how to apply its explicit norms: when to use them or not to use them; when to violate them; when not to use a choice which is offered; when we are effectively obliged to do something, but to have to pretend that we are doing it as a free choice. (xviii-xix) These informal rules, these habits, are thus in place to order a society that is predicated on disorder, on disagreement, and on the structural subjugation of a dissenting minority. Theoretically, the paradoxical nature of democracy presupposes the systematic suppression of rational debate, thus situating violence as the only viable recourse to the violent subversion of peaceful resistance. American democracy, then, is a form of tyranny, not its antithesis. Put in this way, Žižek's claim that the "dictatorship of the proletariat" must be maintained via terror is not nearly so shocking when tyranny and terror are posited as integral parts of even of the seemingly benign democratic structure.

I want to situate my criticism of the venerated white civil rights pioneer Albion Tourgée, as well as of the other white writers I address I this study, within this philosophical framework, specifically with respect to the habits of democratic society. In replicating and acquiescing to the normative habits of majority white supremacy, white liberals become complicit in the very anti- 
egalitarian white supremacist project we/they work to undermine. This line of thinking has potentially debilitating implications for someone like myself, a self-identified white liberal, who is doing similar work in the twenty-first century. In other words, if the disparate agendas of conservative white supremacists like Thomas Dixon and "radical" white liberals like Tourgée are ultimately complementary, as I have argued, what does that say about the future of radical white activism in a white supremacist society? How does that position the cultural work that I am doing in the name of humanitarianism and cross-racial unity?

Tourgée, in advocating for a color-blind consciousness, betrayed the demands of history even in his commendable effort to keep the peace. He promoted a notion of democratic equality that was fundamentally irreconcilable with America's history of race slavery and oppressive violence. His color-blind philosophy, in simplistic terms, suggested that we start over again, that we ignore the past and trust in "the people" to reclaim the present. And reclaim it they did. In the context of Reconstruction and national reconciliation, Tourgée's was ultimately a conciliatory stance, one that sacrificed deep equality for visible civility, and, in turn, helped to obscure an opportunity for real social change inherent in the crisis moment of Reconstruction. In leveling this criticism, I do not mean to suggest that Tourgée was consciously involved in the promotion of white supremacy, but the fact that he was not is even more troubling. Because I want to maintain this pressure on my own work, because I want to remind myself of the dangers of conciliation and the price of peace, I am not prepared to let him off the hook. To do so would be to follow in his erroneous footsteps and to participate in an unproductive discourse of deferral, to acquiesce to the normative habits of white supremacy and racial repression.

Despite my best intentions, I harbor the very real fear, in the back of my mind, that I am merely perpetuating the culture I want to change. Tourgée, after all, was vastly unpopular in his 
time, considered a radical, even risked his life for his ideals and endured significant persecution. (I have as yet done nothing of the sort.) Yet Tourgée was still not radical enough to overcome the constraints of a racist culture, a culture in which the values of race, racism, and terror are ingrained, are built into the discourse of democracy. What I do not want is for my criticism of Tourgée's conciliatory stance, or my reading of Žižek, to suggest that only violence can be radical enough. Or that whites can never be truly radical. To suggest that would certainly be to proliferate racial essentialism, under the guise of cultural construction. As many important thinkers, including Tourgée, have observed, slavery does more harm to the master, in psychological terms, than it does to the slave. With this in mind, perhaps I can suggest that in order to be truly progressive, whites must not be merely liberal but actually radical, at the very least more radical than the virulent white supremacists who actively court and demand the consent of the majority and who demonstrate the explicit and implicit habits of the social order. Whether or not this radicalism requires violence remains to be seen.

Channeling Robespierre, Žižek condemns inaction as complicity in much the same way as I have criticized Tourgée's desire for compromise as conciliation. According to Žižek there are no innocent bystanders in the crucial moments of revolutionary decisions, because, in such moments, innocence itself - exempting oneself from the decision, going on as if the struggle I am witnessing does not really concern me-is the highest form of treason. That is to say, the fear of being accused of treason is my treason, because, even if I 'did not do anything against the revolution', this fear itself, the fact that it emerged in me, demonstrates that my subjective position is external to the revolution, that I experience 'revolution' as an external force threatening me. (xvi) 
In terms of my overall argument, this suggests that peace or order or an egalitarian ideal is not implicit in inaction. I must choose sides, because to refuse to do so is to accept the status quo, to oppose the revolution on the simple grounds that it is "an external force" of which I am not a part. This is, at least in part, why Tourgée's color-blind ideal failed to achieve the social and cultural "revolution" he thought he foresaw. This is also why its progeny continue to fail in the twenty-first century. In a white supremacist society, color-blindness $i$ s acquiescence to the status quo. It is an ideal entrenched within the habits of the majority, a sanctioned violation, a normative function rather than a revolutionary one.

In its March 1968 report, the National Advisory Commission on Civil Disorders, convened by President Lyndon Johnson and led by Illinois governor Otto Kerner, Jr., concluded that "Violence cannot build a better society. Disruption and disorder nourish repression, not justice. They strike at the freedom of every citizen. The community cannot - it will not—-tolerate coercion and mob rule." The implicit "community" is the elite white majority, made up of the "citizens" whose "freedom" is threatened by the unruly underclass black mob, the very mob by which the social order is defined in opposition. Unlike the white mob, which is free to disregard the explicit norms, the black mob exposes the incongruence between the explicit norms and the force of habit, the way those norms are upheld and negotiated within the body politic. These words - Violence cannot build a better society_-written in the spirit of identifying the roots of a social problem and formulating recommendations for its remedy, have the deceptive ring of commitment, of conviction and change. Yet they are ultimately words of conciliation, of reducing the spirit of revolution to a limited discussion of the symptoms of racial oppression. Focusing on the "worst" riots of the summer of 1967, in Newark and Detroit within a two-week period, the Kerner Commission set out to answer three basic questions: "What 
happened? Why did it happen? What can be done to prevent it from happening again?" These guiding questions, apparently transparent in their simplicity, nonetheless neglect to take into consideration the ingrained racial fears and associated rumors, exacerbated in times of economic crisis, that fuel the violence of riot. As the Kerner Commission's systematic recommendations suggest, these questions address the symptoms of racial violence rather than the underlying disease of built-in inequality. Modern race riots, like those investigated by the Kerner Commission, and those in Los Angeles in April of 1992, have their roots in American empire and in the cultural politics of chattel slavery. As Gary Alan Fine and Patricia A. Turner point out, "since the first European slave traders shackled their African captives in the bowels of their ships, there have been rumors that blacks will rise up in rebellion" (42). And history has substantiated many of these rumors.

Yet the historical persistence and the ultimate plausibility of these rumors inspires fear in the elite white majority rather than radical action in solidarity with the oppressed. The normative habits of society call for repression of violent resistance rather than embrasure, and, consequently, for more repression. As Fine and Turner observe, "many whites hold tightly to the protection offered by the second amendment because of their fears of racial violence. They suspect that if they were treated as blacks have routinely been treated, they would rise up in armed revolt against their oppressors" (42-43). Sovereign inequality perpetuates a vicious cycle, as the Kerner Commission's report illustrates. In the riots erupting over the summer of 1967 (as in nineteenth century race riots), "the overwhelming majority of the persons killed or injured in all the disorders were Negro civilians." This, coupled with the Commission's assertion that the “civil disorders of 1967 involved Negroes acting against local symbols of white American society, authority, and property in Negro neighborhoods - rather than against white persons," 
implies that racial violence is both the problem and the exclusive domain of the non-white raced Other. These assurances serve to minimize the fears of white Americans, to remind them that they are not the targets of the implicitly raced violence, that instead their institutions are, which somehow allows for the conceptual separation of societal norms and the institutions that support them. The underlying assumption is similar to that of a color-blind ideal: if we even out the judicial system, if we even out welfare and living conditions for blacks in the ghetto, if we elect a black president, then we are post-race and post-racism.

This is not to say that in following Žižek's argument I am suggesting that white radicalism or cross-racial unity are doomed. In fact, Žižek intimates that true revolution lies in conquering our fears, particularly fears predicated on group membership and identification of Others. "Measured against this background," Žižek writes, "revolutionary-egalitarian figures from Robespierre to John Brown are (potentially, at least) figures without habits: they refuse to take into account the habits that qualify the functioning of a universal rule" (xix). In other words, to be truly radical, one must fundamentally defy the social order. To compromise, is, again, to proliferate the status quo. As Žižek observes

It is only such a radical stance that allows us to break with today's predominant mode of politics, post-political biopolitics, which is a politics of fear, formulated as a defence [sic] against a potential victimization or harassment. Therein resides the true line of separation between radical emancipatory politics and the politics of the status quo: it is not the difference between two different positive visions, sets of axioms, but, rather, the difference between the politics based on a set of universal axioms and the politics which renounces the very constitutive dimension of the political, since it resorts to fear as its ultimate mobilizing principle: fear of immigrants, fear of crime, fear of godless sexual 
depravity, fear of the excessive state itself (with its burdensome taxation), fear of ecological catastrophes - such a (post)politics always amounts to a frightening rally of frightened men. (xxvi)

Robespierre and John Brown, Žižek suggests, subvert the circular nature of fear and incomplete revolution by sacrificing themselves and their subjectivity. Žižek is not necessarily talking about suicide or martyrdom per se, but rather of "the Master [a]s the figure of sovereignty, the one who is not afraid to die" (xvii).

Quite simply, I think it is fair to say that radicalism requires sacrifice, even the sacrifice of the self to greater humanity, which is much easier said than done. I am comforted somewhat by conversations I had not long ago, wherein Donald Pease suggested, and I paraphrase freely here, that Barack Obama's Constitutional movement resituates leadership and society in such a way that renders non-violent radicalism a potential reality. Pease spoke of Obama in terms similar to those Žižek uses to describe Robespierre, in which both situate themselves in relation to the people via the use of the second-person "you" and the first person "we" or "us." Pease positions Obama, as Žižek positions Robespierre: "He is not the master exempted from the collective, the 'I' outside 'we"' (xvi). In his use of "you," when addressing the people, Obama, like Robespierre, invests the people with the leadership power that we (the voting majority) have entrusted in him. It will take the "we" to enact a fundamental change in the structure and habits of the social order. Obama's "we," as Pease points out, is a cross-racial we. It is a serviceoriented volunteerist we. It is an opportunity, as Chesnutt suggests in The Marrow of Tradition, to embrace the potential for real social change inherent in the chaos of the present.

At this moment our nation is indeed at a crossroads, as we have been many times before. "Throughout the [twentieth] century, "Fine and Turner observe, "relations between white and 
black Americans have been marked by persistent tension interrupted by periodic cataclysms. The eruptions occur when the tenuous racial equilibrium becomes disrupted by economic, social, or cultural shifts, unexpected at the time, although clear in retrospect" (44). We are again at a crisis point, wherein the euphemistically-termed economic downturn has and will continue to exacerbate tensions between groups, especially racially-identified groups. There are choices to be made, and those who refuse to act will be guilty of treason, guilty of reaffirming the status quo, of reaffirming the habits of an inherently racist society.

I would like to think that Chesnutt, were he available for comment, would agree. After all, I suggest in chapter 1 that Chesnutt is breaking open an oppressive white supremacist discourse of justified white revolution and the manufactured threat of "negro domination." However, I also argue that Chesnutt is viewing the rupture inherent in the Wilmington race riot as an opportunity for renewal, for a reconfiguration of the social order that can only come from chaos and devastation, and therein from the destruction of racial binaries. Chesnutt's conceptual embrasure of chaos is not predicated on a denial of history, as is Tourgée's flawed color-blind ideal. Rather, Chesnutt recognizes race as a fundamental part of American sociopolitical culture and of the structural mechanisms and habits in place to sustain the cultural order. He does not envision change in terms of conventional definitions of equality, for equality assumes that there is some fundamental balance to be achieved, some linear force of progress yet to be reached. It is in this assumption that racial lines are redrawn, that the problems of the past are reconceived rather than resolved, and that structural white supremacy is further obscured. Chesnutt, however, is primarily concerned with the unpredictable human element, and he imagines a world in which the political order works with rather than against the chaos of human existence. 


\section{Bibliography}

Aaron, Daniel. The Unwritten War: American Writers and the Civil War. The Impact of the Civil War. Ser. ed. Harold M. Hyman. New York: Knopf, 1973.

Adeleke, Tunde. UnAfrican Americans: Nineteenth-Century Black Nationalists and the Civilizing Mission. Lexington: UP of Kentucky, 1998.

Advertisement. The Bookman: A Review of Books and Life 10.6 (1895-1933). New York: Feb. 1900, 833. American Periodical Series Online. 26 March 2008.

Allen, Theodore W. The Invention of the White Race: The Origin of Racial Oppression in Anglo-America. Haymarket. Ser. eds. Mike Davis and Michael Sprinker. New York: Verso, 1997.

Ammons, Elizabeth. "Afterword: Winona, Bakhtin, and Hopkins in the Twenty-first Century." In Gruesser 211-219.

Andrews, William L. The Literary Career of Charles W. Chesnutt. Baton Rouge: Lousiana State UP, 1980.

Aptheker, Herbert. American Negro Slave Revolts. 1943. New York: International, 1963.

- - . . Nat Turner's Slave Rebellion: Together with the Full Text of the So-Called "Confessions" of Nat Turner Made in Prison in 1831. New York: Humanities P, 1966.

Baker, Ray Stannard. Following the Color Line: An Account of Negro Citizenship in the American Democracy. New York: Doubleday, Page, and Co., 1908.

Bauerlein, Mark. Negrophobia: A Race Riot in Atlanta, 1906. San Francisco: Encounter Books, 2001.

Beverly, Robert. The History and Present State of Virginia in Four Parts. I. The History of the First Settlement of Virginia, and the Government thereof, to the present Time. II. The 
Natural Productions and Conveniencies of the Country, suited to Trade and Improvement. III. The Native Indians, their Religion, Laws, and Customs, in War and Peace. IV. The present State of the Country, as to the Polity of the Government, and the Improvements of the Land. By a Native and Inhabitant of the Place. London: Printed for R. Parker, 1705. Documenting the American South. 26 March 2008.

$<$ http://docsouth.unc.edu/southlit/beverley/beverley.html $>$

Blight, David W. Beyond the Battlefield: Race, Memory, and the American Civil War. Amherst: U of Massachusetts P, 2002.

Blum, Edward J. Reforging the White Republic: Race, Religion, and American Nationalism, 1865-1898. Conflicting Worlds: New Dimensions of the American Civil War. Ser. ed. T. Michael Parrish. Baton Rouge: Louisiana State UP, 2005.

Bouvé, Pauline Carrington. “An Aboriginal Author.” Boston Evening Transcript, 23 August 1899, 16. In McElrath, Critical Essays 99-103.

- - - . Their Shadows Before; A Story of the Southampton Insurrection. 1899. Rpt. Freeport, NY: Books for Libraries P, 1972.

“Bouvé, Pauline Carrington.” Who Was Who In America. Vol. 1 (1897-1942). Chicago: Marquis Who's Who, 1962. 120.

Breen, T. H. "A Changing Labor Force and Race Relations in Virginia 1660-1710." Journal of Social History 7.1 (Autumn 1973): 3-25.

Brodhead, Richard, ed. The Journals of Charles W. Chesnutt. Durham: Duke UP, 1993.

Brown, Salmon. "John Brown and Sons in Kansas Territory." Indiana Magazine of History (June 1935): 142-150. 
Bruce, Dickson D. Jr. Black Americans Writing from the Nadir: The Evolution of a Literary Tradition, 1877-1915. Baton Rouge: Louisiana State UP, 1989.

Brundage, W. Fitzhugh. Lynching in the New South: Georgia and Virginia, 1880-1930. Urbana: U of Illinois P, 1993.

- - . "Thomas Dixon: American Proteus.” In Dailey, et al. 23-45.

Carby, Hazel V. Introduction. In Hopkins, Magazine Novels xxix-1.

- - . Reconstructing Womanhood: The Emergence of the Afro-American Woman Novelist. New York: Oxford UP, 1987.

Cecelski, David S. and Timothy B. Tyson, eds. Democracy Betrayed: The Wilmington Race Riot of 1898 and Its Legacy. Chapel Hill: U of North Carolina P, 1998.

Cella, C. Ronald. Mary Johnston. Twayne’s United States Authors Series. Ed. David J. Nordloh. Boston: Twayne, 1981.

Chadwick-Joshua, Jocelyn. The Jim Dilemma: Reading Race in Huckleberry Finn. Jackson: UP of Mississippi, 1998.

Chalmers, David M. Hooded Americanism: The History of the Ku Klux Klan. $3^{\text {rd }}$ ed. Durham: Duke UP, 2000.

Chesnutt, Charles Waddell. The Marrow of Tradition. 1901. Ed. Eric J. Sundquist. New York: Penguin, 1993.

Clarke, John Henrik, ed. William Styron's Nat Turner: Ten Black Writers Respond. Boston: Beacon, 1968.

Clinton, Catherine, and Nina Silber, eds. Divided Houses: Gender and the Civil War. New York: Oxford UP, 1992. 
Coalition to Remember the 1906 Atlanta Race Riot. 2006. 9 Mar. 2009.

$<$ http://www.1906atlantaraceriot.org $>$

Coleman, Finnie D. Sutton E. Griggs and the Struggle Against White Supremacy. Knoxville: U of Tennessee P, 2007.

Cooper, Anna Julia. A Voice From the South. Xenia, OH: Aldine Printing House, 1892.

Documenting the American South. 9 Feb. 2008.

$<$ http://docsouth.unc.edu/church/cooper/cooper.html $>$

Dailey, Jane, Glenda Elizabeth Gilmore, and Bryant Simon, eds. Jumpin'Jim Crow: Southern Politics from Civil War to Civil Rights. Princeton, NJ: Princeton UP, 2000.

Dailey, Jane. "The Limits of Liberalism in the New South: The Politics of Race, Sex, and Patronage in Virginia, 1879-1883." Dailey, et al. 88-114.

Davis, Angela Y. "Rape, Racism, and the Myth of the Black Rapist." Women, Race \& Class. New York: Random House, 1981. 172-201.

Davis, David Brion. Inhuman Bondage: The Rise and Fall of Slavery in the New World. New York: Oxford UP, 2006.

Davis, Mary Kemp. Nat Turner Before the Bar of Judgment: Fictional Treatments of the Southampton Slave Insurrection. Baton Rouge: Louisiana State UP, 1999.

Diffley, Kathleen. Where My Heart is Turning Ever: Civil War Stories and Constitutional Reform, 1861-1876. Athens: U of Georgia P, 1992.

Dixon, Thomas, Jr. The Clansman: An Historical Romance of the Ku Klux Klan. 1905. Ed. Thomas D. Clark. Lexington: UP of Kentucky, 1970.

- - . The Leopard's Spots: A Romance of the White Man's Burden, 1865-1900. New York: Grosset and Dunlop, 1902. 
Doolen, Andy. Fugitive Empire: Locating Early American Imperialism. Minneapolis: U of Minnesota P, 2005.

Doreski, C. K. Writing America Black: Race Rhetoric in the Public Sphere. New York: Cambridge UP, 1998.

Douglass, Frederick. Life and Times of Frederick Douglass: His Early Life as a Slave, His Escape from Bondage, and His Complete History to the Present Time. 1881. Hartford, CT: Park Publishing Co. Documenting the American South. 3 Mar. 2008. $<$ http://docsouth.unc.edu/neh/douglasslife/douglass.html\#douglass277>.

Doyle, Laura. Freedom's Empire: Race and the Rise of the Novel in Atlantic Modernity, 16401940. Durham: Duke UP, 2008.

Dray, Philip. At the Hands of Persons Unknown: The Lynching of Black America. New York: Modern Library, 2002.

Du Bois, W. E. B. Black Reconstruction in America, 1860-1880. 1935. New York: Atheneum, 1992.

- - - John Brown.1909. Armonk, NY: M. E. Sharpe, 1997.

Dunbar, Paul Laurence. The Fanatics. 1901. Salem, NH: Ayer, 1991.

- - . . "The Fourth of July and Race Outrages.” Martin and Hudson, Dunbar Reader 50-51.

- - - . "Recession Never." Martin and Hudson, Dunbar Reader 36-39.

Edmonds, Helen G. The Negro and Fusion Politics in North Carolina, 1894-1901. 1951. Chapel Hill: U of North Carolina P, 2003.

Edwards, Laura F. Gendered Strife and Confusion: The Political Culture of Reconstruction. Women in American History. Ser. eds. Mari Jo Buhle, Nancy A. Hewitt, and Anne Firor Scott. Urbana: U of Illinois P, 1997. 
Elliott, Mark. Color-Blind Justice: Albion Tourgée and the Quest for Racial Equality from the Civil War to Plessy v. Ferguson. New York: Oxford UP, 2006.

Ernest, John. Resistance and Reformation in Nineteenth-Century African-American Literature: Brown, Wilson, Jacobs, Delany, Douglass, and Harper. Jackson: UP of Mississippi, 1995.

"Excerpts from the Kerner Report." History Matters: The U.S. Survey Course on the Web. Center for History and New Media. George Mason University. 1998-2005. 2 Mar. 2009. $<$ http://historymatters.gmu.edu/d/6545/>

Fahs, Alice. The Imagined Civil War: Popular Literature of the North and South, 1861-1865. Civil War America. Ser. ed. Gary W. Gallagher. Chapel Hill: U of North Carolina P, 2001.

Faust, Drew Gilpin. “Altars of Sacrifice: Confederate Women and the Narratives of War.” 1990. Southern Stories: Slaveholders in Peace and War. Columbia: U of Missouri P, 1992. 113-140.

"Final Report of the Oklahoma Commission to Study the Tulsa Race Riot of 1921." Oklahoma Historical Society. Oklahoma City, OK. 2 Mar. 2009. $<$ http://www.okhistory.org/trrc/freport.htm>

Fine, Gary Alan and Patricia A. Turner. Whispers on the Color Line: Rumor and Race in America. Berkeley: U of California P, 2001.

Fishkin, Shelley Fisher. Was Huck Black? Mark Twain and African American Voices. New York: Oxford UP, 1993.

Foner, Eric. Politics and Ideology in the Age of the Civil War. New York: Oxford UP, 1980. 
- - - Reconstruction: America's Unfinished Revolution: 1863-1877. 1988. Francis Parkman Prize ed. New York: HarperCollins, 2005.

"For the Record: Representations of the Wilmington Massacre of 1898." Ed. Shaun Thomas. University of Maryland-College Park. 22 Oct. 2007 $<$ http://www.mith.umd.edu/courses/amvirtual/wilmington/wilmington.html $>$

Fredrickson, George M. The Black Image in the White Mind: The Debate on Afro-American Character and Destiny, 1817-1914. Middletown, CT: Wesleyan UP, 1971.

- - - The Inner Civil War: Northern Intellectuals and the Crisis of the Union. New York: Harper and Row, 1965.

French, Scot. The Rebellious Slave: Nat Turner in American Memory. Boston: Houghton Mifflin, 2004.

Fulton, David Bryant [Jack Thorne]. Hanover; Or, The Persecution of the Lowly. 18--. M. C. L. Hill. Documenting the American South. 2001. U of North Carolina at Chapel Hill. 8 Aug. 2007. <http://docsouth.unc.edu/nc/thorne/thorne.html>

Fulton, Joe B. Mark Twain in the Margins: The Quarry Farm Marginalia and A Connecticut Yankee in King Arthur's Court. Tuscaloosa: U of Alabama P, 2000.

Gardner, Sarah E. Blood and Irony: Southern White Women's Narratives of the Civil War, 18611937. Chapel Hill: U of North Carolina P, 2004.

Geffert, Hannah. “They Heard His Call: The Local Black Community's Involvement in the Raid on Harpers Ferry." In Russo and Finkelman 23-45.

Gerard, Philip. Cape Fear Rising. Winston-Salem, NC: John F. Blair, 1994.

Gilje, Paul A. Rioting in America. Bloomington: Indiana UP, 1996. 
- - . The Road to Mobocracy: Popular Disorder in New York City, 1763-1834. Chapel Hill: U of North Carolina P, 1987.

Gillespie, Michele K. and Randall L. Hall, eds. Thomas Dixon Jr. and the Birth of Modern America. Baton Rouge: Louisiana State UP, 2006.

Gillman, Susan. Blood Talk: American Race Melodrama and the Culture of the Occult. Chicago: U of Chicago P, 2003.

Gilmore, Glenda Elizabeth. Gender and Jim Crow: Women and the Politics of White Supremacy in North Carolina, 1896-1920. Chapel Hill: U of North Carolina Press, 1996.

Goff, H. N. K. (Harriet Newell Kneeland). Other Fools and Their Doings; Or, Life Among the Freedmen. New York: J.S. Ogilvie, 1880.

Goldberg, David Theo. Racist Culture: Philosophy and the Politics of Meaning. Cambridge, MA: Blackwell, 1993.

Gossett, Thomas F. Race: The History of an Idea in America. Sourcebooks in Negro History. New York: Schocken Books, 1965.

Greenberg, Kenneth S., ed. Nat Turner: A Slave Rebellion in History and Memory. New York: Oxford UP, 2003.

- - . "Name, Face, Body.” In Greenberg 3-23.

Griggs, Sutton E. Guide to Racial Greatness; Or, The Science of Collective Efficiency. Memphis, TN: National Public Welfare League, 1923.

- - - Imperium in Imperio. 1899. New York: Modern Library, 2003.

- - . Wisdom's Call. Nashville, TN: Orion Publishing, 1911. 
Grigsby, John L. 'Jesus, Judas, Job or 'Jes a Happy Ole Nigga': Or, Will the Real 'Uncle Tom' Please Step Forward?” Publications of the Mississippi Philological Association (1986): $51-62$.

Griffith, D. W. The Birth of a Nation. 1915. Reel Enterprises, 2006.

Grimsted, David. American Mobbing, 1828-1861: Toward Civil War. New York: Oxford UP, 1998.

Gross, Ariela J. What Blood Won't Tell: A History of Race on Trial in America. Cambridge: Harvard UP, 2008.

Gruesser, John Cullen, ed. The Unruly Voice: Rediscovering Pauline Elizabeth Hopkins. Urbana: U of Illinois P, 1996.

Gunning, Sandra. Race, Rape, and Lynching: The Red Record of American Literature, 18901912. Race and American Culture. Ser. eds. Arnold Rampersad and Shelley Fisher Fishkin. New York: Oxford UP, 1996.

Hahn, Steven. A Nation Under Our Feet: Black Political Struggles in the Rural South from Slavery to the Great Migration. Cambridge: Belknap P, 2003.

Hair, William Ivy. Carnival of Fury: Robert Charles and the New Orleans Race Riot of 1900. Baton Rouge: Louisiana State UP, 1976.

Hale, Grace Elizabeth. Making Whiteness: The Culture of Segregation in the South, 1890-1940. New York: Pantheon, 1998.

Haley, John. "Race, Rhetoric, and Revolution.” In Cecelski and Tyson 207-224.

Hammond, Scott John. “John Brown as Founder: America’s Violent Confrontation with Its First Principles.” In Russo and Finkelman 61-76. 
Haney Lopez, Ian F. White By Law: The Legal Construction of Race. New York: New York UP, 1996.

Hardwig, Bill. "Who Owns the Whip?: Chesnutt, Tourgée, and Reconstruction Justice.” African American Review 36.1 (2002): 5-20.

Harris, Turdier. Exorcising Blackness: Historical and Literary Lynching and Burning Rituals. Bloomington, Indiana UP, 1984.

Hartman, Saidiya V. Scenes of Subjection: Terror, Slavery, and Self-Making in NineteenthCentury America. New York: Oxford UP, 1997.

Hatt, Michael. "Race, Ritual, and Responsibility: Performativity and the Southern Lynching." Performing the Body/Performing the Text. Eds. Amelia Jones and Andrew Stephenson. New York: Routledge, 1999. 76-88.

Hinton, Richard J. John Brown and His Men, With Some Account of the Roads They Traveled to Reach Harper's Ferry. New York: Funk and Wagnalls, 1894.

Hodes, Martha. "Wartime Dialogues on Illicit Sex: White Women and Black Men." In Clinton and Silber 230-242.

Hopkins, Pauline Elizabeth. Contending Forces: A Romance Illustrative of Negro Life North and South. The Schomberg Library of Nineteenth-Century Black Women Writers. Ser. ed. Henry Louis Gates, Jr. New York: Oxford UP, 1988.

- - - . The Magazine Novels of Pauline Hopkins. The Schomberg Library of Nineteenth-Century Black Women Writers. Ser. ed. Henry Louis Gates, Jr. New York: Oxford UP, 1988. Horsman, Reginald. Race and Manifest Destiny: The Origins of American Racial AngloSaxonism. Cambridge: Harvard UP, 1981. 
Hughes, Jennifer A. "The Politics of Incongruity in Paul Laurence Dunbar's The Fanatics." African American Review 41.2 (Summer 2007): 295-301.

Hull, Gloria T. "Notes on a Marxist Interpretation of Black American Literature.” Black American Literature Forum 12.4 (1978): 148-153.

Jacobson, Matthew Frye. Whiteness of a Different Color: European Immigrants and the Alchemy of Race. Cambridge: Harvard UP, 1998.

James, Jennifer C. A Freedom Bought with Blood: African American War Literature from the Civil War to World War II. Chapel Hill: U of North Carolina P, 2007.

Johnson, Michael P. "Denmark Vesey and His Co-Conspirators.” William and Mary Quarterly $3^{\text {rd }}$ Ser. 58.4 (Oct. 2001): 915-976.

Johnston, Mary. Prisoners of Hope: A Tale of Colonial Virginia. Boston: Houghton Mifflin, 1898.

Jones, Martha S. All Bound Up Together: The Woman Question in African American Public Culture, 1830-1900. John Hope Franklin Series in African American History and Culture. Ser. eds. Waldo E. Martin Jr. and Patricia Sullivan. Chapel Hill: U of North Carolina P, 2007.

Kachun, Mitch. Festivals of Freedom: Memory and Meaning in African American Emancipation Celebrations, 1808-1915. Amherst: U of Massachusetts P, 2003.

Kantrowitz, Stephen. “One Man’s Mob Is Another Man’s Militia: Violence, Manhood, and Authority in Reconstruction South Carolina.” In Dailey et al. 67-87.

- - . "The Two Faces of Domination in North Carolina, 1800-1898." In Cecelski and Tyson 95-111. 
Kaplan, Amy. The Anarchy of Empire in the Making of U.S. Culture. Convergences:

Inventories of the Present. Ser. ed. Edward Said. Cambridge: Harvard UP, 2002.

King, Martin Luther, Jr. Where Do We Go From Here: Chaos or Community? Boston: Beacon P, 1967.

Kinshasa, Kwando Mbiassi. Black Resistance to the Ku Klux Klan in the Wake of the Civil War. Jefferson, NC: McFarland, 2006.

Leonard, James S. and Thomas Tenney, eds. Satire or Evasion? Black Perspectives on Huckleberry Finn. Durham: Duke UP, 1999.

Litwack, Leon F. Been in the Storm So Long: The Aftermath of Slavery. 1979. New York: Vintage, 1980.

- - . Trouble in Mind: Black Southerners in the Age of Jim Crow. 1998. New York: Vintage, 1999.

Long, Lisa A. Rehabilitating Bodies: Health, History, and the American Civil War. Philadelphia: U of Pennsylvania P, 2004.

Longest, George C. Three Virginia Writers; Mary Johnston, Thomas Nelson Page, and Amélie Rivers Troubletzkoy: A Reference Guide. Boston: G. K. Hall, 1978.

Lowery, J. Vincent. "Remembering 1898: Literary Responses and Public Memory of the Wilmington Race Riot.” Appendix M. In WRRC 414-428.

Martin, Jay, ed. A Singer in the Dawn: Reinterpretations of Paul Laurence Dunbar. New York: Dodd, Mead, and Co., 1975.

Martin, Jay, and Gossie H. Hudson, eds. The Paul Laurence Dunbar Reader. New York: Dodd, Mead, and Co., 1975. 
Martinez, J. Michael. Carpetbaggers, Cavalry, and the Ku Klux Klan: Exposing the Invisible Empire During Reconstruction. American Crisis Series: Books on the Civil War Era. Ser. ed. Steven E. Woodworth. Lanham, MD: Rowman and Littlefield, 2007.

Masur, Louis P. "Nat Turner and Sectional Crisis.” In Greenberg 148-161,

McElrath, Joseph R., ed. Critical Essays on Charles W. Chesnutt. New York: G. K. Hall, 1999.

McElrath, Joseph R., Jr., Robert C. Leitz, III, and Jesse S. Crisler, eds. Charles W. Chesnutt: Essays and Speeches. Stanford, CA: Stanford UP, 1999.

McElrath, Joseph R., Jr., and Robert C. Leitz, III, eds. “To Be An Author”: Letters of Charles W. Chesnutt, 1889-1905. Princeton, NJ: Princeton UP, 1997.

McGlone, Robert E. “Rescripting a Troubled Past: John Brown's Family and the Harpers Ferry Conspiracy." Journal of American History 75.4 (1989): 1179-1200.

Micheaux, Oscar. Witihin Our Gates. Evelyn Preer, Alma Pritchard. 1920.

Miller, Kelly. Out of the House of Bondage. The American Negro: His History and Literature. Ser. ed. William Loren Katz. New York: Arno P, 1969.

- - . Radicals and Conservatives And Other Essays on the Negro in America. 1908. New York: Schocken, 1968.

Mitchell, J. Paul, ed. Race Riots in Black and White. Englewood Cliffs, NJ: Prentice-Hall, 1970.

Mitchell, Michele. Righteous Propagation: African Americans and the Politics of Racial Destiny after Reconstruction. Chapel Hill: U of North Carolina P, 2004.

Morrison, Toni. Playing in the Dark: Whiteness and the Literary Imagination. The William E. Massey Sr. Lectures in the History of American Civilization. New York: Vintage, 1990. Moses, Norton H. Lynching and Vigilantism in the United States: An Annotated Bibliography. Westport, CT: Greenwood, 1997. 
Neely, Mark E. Jr. The Boundaries of American Political Culture in the Civil War Era. The Steven and Janice Brose Lectures in the Civil War Era. Ser. ed. William A. Blair. Chapel Hill: U of North Carolina P, 2005.

Nelson, Dana D. National Manhood: Capitalist Citizenship and the Imagined Fraternity of White Men. New Americanists. Ser. ed. Donald E. Pease. Durham: Duke UP, 1998.

Nelson, Lawrence G. "Mary Johnston and the Historic Imagination." Southern Writers: Appraisals in Our Time. Ed. R. C. Simonini, Jr. Charlottesville: U of Virginia P, 1964.

“New Publications.” The Literary World; A Monthly Review of Current Literature 31.10 (18701904). Boston: 1 August 1900, 157. American Periodicals Series Online. 26 March 2008.

Newton, Michael, and Judy Ann Newton. Racial and Religious Violence in America: A Chronology. New York: Garland, 1991.

Nudelman, Franny. John Brown's Body: Slavery, Violence, and the Culture of War. Chapel Hill: U of North Carolina P, 2004.

Oshinsky, David M. “Worse Than Slavery”: Parchman Farm and the Ordeal of Jim Crow Justice. New York: Simon \& Schuster, 1996.

Parramore, Thomas C. “Covenant in Jerusalem.” In Greenberg 58-76.

Patterson, Martha H. ““'kin’ o’ rough jestice fer a parson’: Pauline Hopkins’s Winona and the Politics of Reconstructing History.” African American Review 32.3 (1998): 445-460.

Pease, Donald. “Antigone’s Kin: From Abu Ghraib to Barrack Obama.” Eberly Family Distinguished Lecture Series. West Virginia University, Morgantown. 27 Feb. 2009. Perman, Michael. Struggle for Mastery: Disfranchisement in the South, 1888-1908. Fred W. Morrison Series in Southern Studies. Chapel Hill: U of North Carolina P, 2001. 
Pettis, Joyce. "The Literary Imagination and the Historic Event: Chesnutt's Use of History in The Marrow of Tradition." South Atlantic Review 55.4 (1990): 37-48.

Prather, H. Leon, Sr. "We Have Taken a City: A Centennial Essay.” In Cecelski and Tyson 1541.

- - . We Have Taken a City: Wilmington Racial Massacre and Coup of 1898. Cranberry, NJ: Associated University Presses, 1984.

Pressly, Thomas J. Americans Interpret Their Civil War. New York: Free Press, 1966.

Quarles, Benjamin. Allies for Freedom and Blacks on John Brown. 1974 and 1972. Da Capo, 2001.

"Race War is Coming, Says Senator Tillman.” New York Times 8 Oct. 1906: 1.

Richardson, Heather Cox. The Death of Reconstruction: Race, Labor, and Politics in the PostCivil War North, 1865-1901. Cambridge: Harvard UP: 2001.

Robespierre, Maximilien. Virtue and Terror. Trans. John Howe. Ed. Slavoj Žižek. New York: Verso, 2007.

"Rocking the Old Cradle of Liberty." Liberator (1831-1865). 18 Oct. 1850, 166-167. American Periodicals Series Online. 26 April 2008.

Roe, Jae H. 'Keeping an 'Old Wound' Alive: The Marrow of Tradition and the Legacy of Wilmington.” African American Review 33.2 (1999): 231-243.

Roediger, David R. The Wages of Whiteness: Race and the Making of the American Working Class. 1991. Revised ed. New York: Verso, 1999.

Romine, Scott. "Thomas Dixon and the Literary Production of Whiteness." In Gillespie and Hall 124-150. 
“Rosewood Bibliography.” Elaine Dickinson. Florida Department of State. State Archives and History of Florida. 2004-2008. 2 Mar. 2009.

$<$ http://dlis.dos.state.fl.us/library/bibliographies/Rosewood_bib.cfm>

Rowe, John Carlos. Literary Culture and U.S. Imperialism: From the Revolution to World War II. New York: Oxford UP, 2000.

Royall, William L. A Reply to “A Fool's Errand, By One of the Fools.” New York: E. J. Hale, 1881.

Russo, Peggy A. and Paul Finkelman, eds. Terrible Swift Sword: The Legacy of John Brown. Athens: Ohio UP, 2005.

Ryan, Mary P. Mysteries of Sex: Tracing Women and Men Through American History. Chapel Hill: U of North Carolina Press, 2006.

Sadler, Lynn Veach. "The Figure of the Black Insurrectionist in Stowe, Bouvé, Bontemps, and Gaither: The Universality of the Need for Freedom.” MAWA Review 2.1 (1986): 21-24.

Samuels, Shirley. Facing America: Iconography and the Civil War. New York: Oxford UP, 2004.

Sanborn, Franklin B., ed. Life and Letters of John Brown, Liberator of Kansas, and Martyr of Virginia. 1885. Rprt. New York: Negro Universities Press, 1969.

Schmidt, Peter. Sitting in Darkness: New South Fiction, Education, and the Rise of Jim Crow Colonialism, 1865-1920. Jackson: UP of Mississippi, 2008.

Schmitz, Neil. “Mark Twain, Traitor.” Arizona Quarterly 63.4 (2007): 25-37.

“Servants' Plot.” Virginia African American Heritage Program. Virginia Foundation for the Humanities. 26 March 2008. $<$ http://www.aaheritageva.org/search/sites.php?site_id=444> 
Silber, Nina. The Romance of Reunion: Northerners and the South, 1865-1900. Civil War America. Ser. ed. Gary W. Gallagher. Chapel Hill: U of North Carolina P, 1993. Sizer, Lyde Cullen. The Political Work of Northern Women Writers and the Civil War, 18501872. Civil War America. Ser. ed. Gary W. Gallagher. Chapel Hill: U of North Carolina P, 2000.

Smith, Henry Nash. Mark Twain's Fable of Progress: Political and Economic Ideas in A Connecticut Yankee. New Brunswick, NJ: Rutgers UP, 1964.

Smith, John David. “'My Books Are Hard Reading for a Negro': Tom Dixon and His African American Critics, 1905-1939.” In Dailey et al. 46-79.

Smith, Kimberly K. The Dominion of Voice: Riot Reason, and Romance in Antebellum Politics. Lawrence: UP of Kansas, 1999.

Smith, Mark M. How Race Is Made: Slavery, Segregation, and the Senses. Chapel Hill: U of North Carolina P, 2006.

Smith McKoy, Sheila. When Whites Riot: Writing Race and Violence in American and South African Cultures. Madison: U of Wisconsin P, 2001.

Sommerville, Diane Miller. Rape and Race in the Nineteenth-Century South. Chapel Hill: U of North Carolina P, 2004.

Stokes, Mason. The Color of Sex: Whiteness, Heterosexuality, and the Fictions of White Supremacy. New Americanists. Ser. ed. Donald E. Pease. Durham: Duke UP, 2001.

Stowe, Harriet Beecher. Dred: A Tale of the Great Dismal Swamp. 1856. Ed. Robert S. Levine. Chapel Hill: U of North Carolina P, 2000.

Sundquist, Eric J. Introduction. In Chesnutt vii-xliv. 
- - - To Wake the Nations: Race in the Making of American Literature. Cambridge, MA:

Belknap P, 1993.

Sweet, Timothy. Traces of War: Poetry, Photography, and the Crisis of the Union. Parallax:

Re-visions of Culture and Society. Ser. eds. Stephen G. Nichols, Gerald Price, and Wendy Steiner. Baltimore: Johns Hopkins UP, 1990.

Tal, Kali. “Black Militant Near-Future Fiction.” Social Text 7120.2 (2002): 65-91.

Tourgée, Albion W. A Fool's Errand: By One of the Fools. 1879. Ed. John Hope Franklin. Cambridge: Belknap, 1961.

- - - . A Fool's Errand and The Invisible Empire. New York: Fords, Howard \& Hulbert, 1879 and 1880.

Townsley, James. "The Pottawatomie Killings: It is Established Beyond Controversy That John Brown Was the Leader." Republican Citizen 20 Dec. 1879. 20. Kansas History. 3 May 2008. <http://www.kansashistory.us/pottamassacre.html>

Trelease, Allen W. White Terror: The Ku Klux Klan Conspiracy and Southern Reconstruction. Baton Rouge: Louisiana State UP, 1999.

Twain, Mark. A Connecticut Yankee in King Arthur's Court. 1889. Ed. Bernard L. Stein. Mark Twain Project of the Bancroft Library. Berkeley: U of California P, 1984.

- - - . The Adventures of Huckleberry Finn. 1884. New York: Bantam, 1981.

- - - . "To the Person Sitting in Darkness." Great Short Works of Mark Twain. Ed. Justin Kaplan. New York: Harper and Row, 1967. 201-217.

Waddell, Col. Alfred M. “The Story of the Wilmington, N.C. Race Riots.” Collier's Weekly 26 Nov. 1898: 4-5. 
Wade, Wyn Craig. The Fiery Cross: The Ku Klux Klan in America. New York: Oxford UP, 1998.

Wagenknecht, Edward. “The World and Mary Johnston.” Sewanee Review 44 (1936): 188-206.

Wagner, Bryan. "Charles Chesnutt and the Epistemology of Racial Violence." American Literature 73.2 (2001): 311-337.

Wallinger, Hanna. Pauline E. Hopkins: A Literary Biography. Athens: U of Georgia P, 2005.

Webb, Stephen Saunders. 1676: The End of American Independence. Syracuse: Syracuse UP, 1995.

Weisenburger, Steven. Modern Medea: A Family Story of Slavery and Child-Murder from the Old South. New York: Hill and Wang, 1998.

Wells, Benjamin W. "Southern Literature of the Year." Forum (1886-1930). New York: June 1900, 501-512. American Periodicals Series Online. 26 March 2008.

Wells, Ida B. Southern Horrors and Other Writings: The Anti-Lynching Campaign of Ida B. Wells, 1892-1900. Ed. Jacqueline Jones Royster. Bedford: Boston, 1997.

Wexler, Laura. Tender Violence: Domestic Visions in an Age of U.S. Imperialism. Chapel Hill: U of North Carolina P, 2000.

White, Ed. The Backcountry and the City: Colonization and Conflict in Early America. Minneapolis: U of Minnesota P, 2005.

Whites, LeeAnn. "Love Hate, Rape, Lynching: Rebecca Latimer Felton and the Gender Politics of Racial Violence.” In Cecelski and Tyson 143-162.

Wilmington Race Riot Commission (WRRC). 1898 Wilmington Race Riot Final Report. 31 May 2006. North Carolina Department of Cultural Resources. 1 Oct. 2007. $<$ http://www.ah.dcr.state.nc.us/1898-wrrc/report/report.htm>. 
Wilson, Edmund. Patriotic Gore: Studies in the Literature of the American Civil War. New York: Oxford UP, 1962.

Wilson, Matthew. Whiteness in the Novels of Charles W. Chesnutt. Jackson: U of Mississippi P, 2004.

Wood, Forrest G. Black Scare: The Racist Response to Emancipation and Reconstruction. Berkeley: U of California P, 1968.

Woodbridge, Annie, and Hensley C. Woodbridge, eds. The Collected Short Stories of Mary Johnston. Troy, NY: Whitson, 1982.

Young, Elizabeth. Disarming the Nation: Women's Writing and the American Civil War. Women in Culture and Society. Ser. ed. Catharine R. Stimpson. Chicago: U of Chicago P, 1999.

Young, Joseph A. “Erasure and Retrieval of Public Memory: Artful Deceit in Mary Johnston's Prisoners of Hope and Subtle Disclosure in Pauline Bouvé's Their Shadows Before." Erasing Public Memory: Race, Aesthetics, and Cultural Amnesia in the Americas. Eds. Joseph A. Young and Jana Evans Braziel. Macon, GA: Mercer UP, 2007. 71-117. Zackodnik, Teresa C. The Mulatta and the Politics of Race. Jackson: UP of Mississippi, 2004.

Žižek, Slavoj. “Robespierre, Or, The ‘Divine Violence' of Terror.” Introduction. In Robespierre vii-xxxix. 


\title{
Curriculum Vitae
}

\section{REBECCA SKIDMORE BIGGIO}

\author{
rskidmo1@mix.wvu.edu
}

Department of English, West Virginia University, 1503 University Avenue, PO Box 6296, Morgantown, WV 26506-6296 (304) 293-3107

\section{EDUCATION}

Ph.D. American Literature, West Virginia University, 2009

Dissertation: The Riotous Presence in American Literature and Culture

Director: Dr. John Ernest

Futures of American Studies Institute, Dartmouth College, Hanover, NH, Summer 2007

M.A. Literature, University of North Carolina at Wilmington, 2002

Thesis: The Terror Unspooled: Narratives of Place and Identity in Arundhati Roy's The

God of Small Things

Director: Dr. Cara Cilano

B.A. English, Virginia Polytechnic Institute and State University, 2000

\section{PUBLICATIONS}

"The Specter of Conspiracy in Martin Delany's Blake." Forthcoming in African American Review.

“Gayl Jones." African American National Biography. Vol. 4 (Hatcher-Jones, Sarah). Eds.

Henry Louis Gates, Jr. and Evelyn Brooks Higginbotham. New York: Oxford UP, 2008. 653-654.

"Off the Tenure-Track: Advocating Alternative Career Choices for English Ph.D.s." Professional Studies Review 2.2 (2006): 16-26.

\section{TEACHING EXPERIENCE}

University of Pittsburgh, Pittsburgh, PA (Fall 2008)

Seminar in Composition (EngComp 0200), 2 sections 


\section{TEACHING EXPERIENCE, continued}

West Virginia University, Morgantown, WV (Fall 2003-Spring 2007)

Composition and Rhetoric (English 101), 4 sections

Composition and Rhetoric (English 102), 5 sections

Business and Professional Writing (English 304), 4 sections

Introduction to the Short Story (English 233)

American Literature, 1865-present (English 242)

Central Virginia Community College, Lynchburg, VA (Fall 2002-Spring 2003)

Pre-College Writing (English 03)

College Composition I (English 111)

College Composition II (English 112)

Writing for Business (English 116), 2 sections

Virginia Western Community College, Roanoke, VA (Spring 2003)

College Composition II (English 112), substitute in technology classroom

Cape Fear Community College, Wilmington, NC (Spring 2002)

African American Literature (English 273), internship

\section{CONFERENCE PRESENTATIONS}

"Resurrecting the Black Prophet: The Politics of Insurrection in Pauline Carrington Bouvé's Their Shadows Before." MLA, San Francisco, CA, December 27-30, 2008.

"'In Season and Out': The Riotous Presence in American Literature and Culture," Futures of American Studies Institute, Dartmouth College, Hanover, NH, June 18-24, 2007.

"The Specter of Conspiracy in Martin Delany's Blake," MLA, Philadelphia, PA, December 2730, 2006.

"From Nat to Blacus: Reclaiming Naming in Martin Delany's Blake," MLA, Philadelphia, PA, December 27-30, 2006.

"White Violence, Black Criminalization: The Wilmington Massacre of 1898," PAMLA, Malibu, CA, November 11-13, 2005.

"An Argument for the Inclusion of $A$ Brief Description of Carolina," WVU Graduate Student Colloquium, Morgantown, WV, April 1-2, 2005.

"Paradoxes of Progress: Literacy and Nuclear Holocaust in Riddley Walker," Southern Humanities Council Annual Conference, Chattanooga, TN, February 5-8, 2004. 


\section{ACADEMIC AWARDS AND HONORS}

West Virginia University Dissertation Fellowship, WVU, Spring 2009

Vehse Award for Doctoral Student Travel, WVU, 2008

Wilson Grant for Doctoral Student Research, WVU, 2008

Honorable Mention. Ford Foundation Diversity Fellowships Program Dissertation Competition, 2008

Stephen Crocker Dissertation Fellowship, WVU, 2007-2008

Jackson Family Doctoral Fellowship, WVU, 2003-2007

HERF Doctoral Fellowship, WVU, 2003-2007

Vehse Award for Doctoral Student Travel, WVU, 2005

\section{PROFESSIONAL EXPERIENCE}

Instructor and Writing Center Consultant, University of Pittsburgh, Fall 2008

Graduate Teaching Assistant, WVU, 2003-2007

Administrative Assistant, Eberly College Summer Seminar in Literary and Cultural Studies with Dr. Joycelyn K. Moody, WVU, June 7-10, 2007

Research Assistant, Dr. John Ernest, Eberly Family Distinguished Professor of American Literature, WVU, 2006-2007

Writing Across the Curriculum Assistant Coordinator, WVU, 2006-2007

Mentor Coordinator and Assistant to Dr. Laura Brady, Director, Center for Writing Excellence, WVU, 2005-2006

Peer Mentor, WVU, 2004-2005

\section{UNIVERSITY SERVICE}

Undergraduate Writing Committee member, WVU, 2005-2006

Chair, English 101 Textbook Committee, WVU, 2005-2006

Activities Representative, WVU English Graduate Organization, 2004-2005

Member, WVU English Graduate Organization, 2003-present 


\section{PROFESSIONAL SERVICE}

Middle Atlantic Representative, MLA Delegate Assembly, 2009-2012

President, SAMLA Graduate Student Forum, 2004-2005

Secretary, SAMLA Graduate Student Forum, 2003-2004

Facilitator, WVU Conference on Quality Teacher Preparation, October 1, 2004

\section{COMMUNITY SERVICE}

Volunteer, Appalachian Prison Book Project, 2004-present

President, Appalachian Prison Book Project, 2006-2008

Treasurer, Appalachian Prison Book Project, 2005-2006

\section{REFERENCES}

Dr. John Ernest, Eberly Family Distinguished Professor of American Literature, Department of English, West Virginia University, 1503 University Avenue, Morgantown, WV 26506-6296, john.ernest@mail.wvu.edu, (304) 293-9714

Dr. Timothy Dow Adams, Professor, Department of English, West Virginia University, 1503 University Avenue, Morgantown, WV 26506-6296, tim.adams@mail.wvu.edu, (304) 293-9700

Dr. Kathleen Ryan, Associate Professor, Department of English, West Virginia University, 1503 University Avenue, Morgantown, WV 26506-6296, kohearnr@wvu.edu, (304) 293-9729

Dr. Timothy Sweet, Professor, Department of English, West Virginia University, 1503 University Avenue, Morgantown, WV 26506-6296, tsweet@wvu.edu, (304) 293-3988

Dr. Kenneth Fones-Wolf, Professor, Department of History, West Virginia University, 202C Woodburn Hall, Morgantown, WV 26506-6303, kenneth.fones-wolf@mail.wvu.edu, (304) 293-2421 ext. 5240 